Priscila Faricelli de Mendonça

TRANSAÇÃO E ARBITRAGEM NAS CONTROVÉRSIAS TRIBUTÁRIAS

Dissertação de Mestrado

Orientador: Professor CARLos AlbERTo de SALLES

Faculdade de Direito da Universidade de São Paulo São Paulo - 2013 
Priscila Faricelli de Mendonça

\title{
TRANSAÇÃO E ARBITRAGEM NAS CONTROVÉRSIAS TRIBUTÁRIAS
}

\author{
Dissertação apresentada à Banca \\ Examinadora da Faculdade de Direito da \\ Universidade de São Paulo como exigência \\ parcial para obtenção do título de Mestre em \\ Direito junto ao Departamento de Direito \\ Processual - Área de Direito Processual \\ Civil, sob a orientação do Prof. Dr. CARLOS \\ ALBERTO DE SALLES.
}

Faculdade de Direito da Universidade de São Paulo São Paulo - 2013 


\section{SUMÁRIO}

INTRODUÇÃ

PARTE I - DIREITO TRIBUTÁRIO E PROCESSO........................................... 17

CAPÍTULO 1 - Um retrato dos processos judiciais tributários 17

CAPÍTULO 2 - A controvérsia tributária frente à atual concepção do interesse público 25

2.1. Nova conjuntura econômica, social e política: justificativa e premissa para mudanças 25

2.2. Releitura acerca da concepção de indisponibilidade do interesse público.... 33

2.3. Natureza da controvérsia tributária 40

CAPÍTULO 3 - Direito processual tributário positivado......................................46

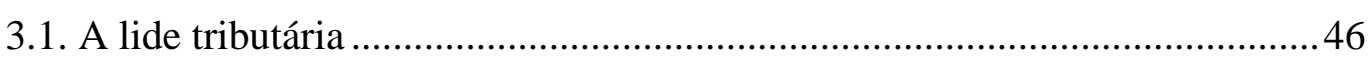

3.2. Notas sobre as formas de solução de controvérsias tributárias positivadas .. 49

3.2.1. Métodos preventivos à constituição do crédito tributário 49

3.2.2. Métodos para questionar o crédito tributário já constituído .54

3.3. O processo, os métodos alternativos e o direito tributário. 58

PARTE II - ARBITRAGEM .66

CAPÍTULO 1 - Arbitrabilidade das controvérsias tributárias ..........................66 66

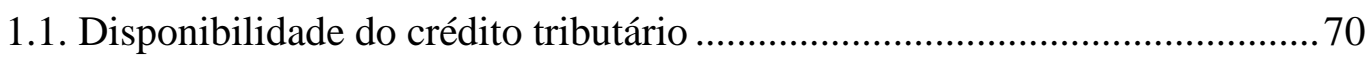

1.2. A arbitragem representa disposição do crédito tributário? .......................... 75

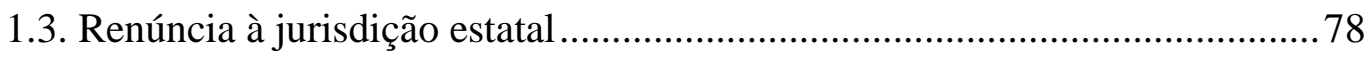

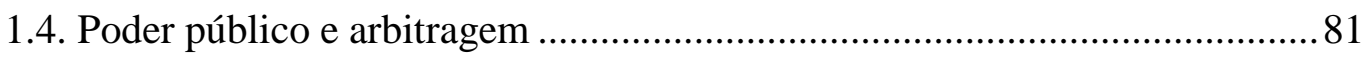

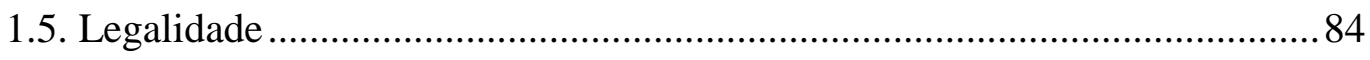


1.5.1. A necessária previsão legal 87

1.5.2. Investigando a necessidade de edição de lei com status complementar 88

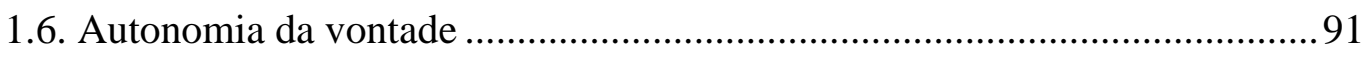

1.7. Vantagens da arbitragem na seara tributária .............................................. 95

CAPÍTULO 2 - ASPECTOS PROCESSUAIS NA ARBITRAGEM 99

2.1. Notas sobre procedimento arbitral tributário brasileiro, datado do Império 100

2.2. O objeto da arbitragem tributária 102

2.2.1. O momento de instauração da arbitragem......................................... 103

2.2.2. Limites materiais da arbitragem tributária ........................................ 105

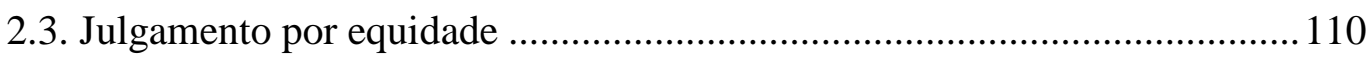

2.4. Competência para submeter o conflito à solução arbitral ........................... 111

2.5. Cláusula compromissória e compromisso arbitral .......................................113

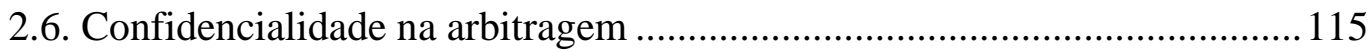

2.7. A definição do procedimento da arbitragem ............................................ 117

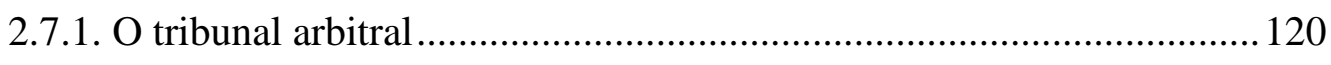

2.7.2. A composição do tribunal arbitral................................................... 121

2.8. Cumprimento da sentença arbitral e o Judiciário....................................... 123

2.9. Possibilidade de constituição de obrigação pecuniária contra a fazenda

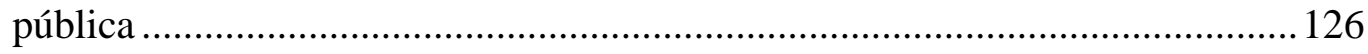

2.10. A extinção do crédito tributário e a sentença arbitral ..............................129

PARTE III - TRANSAÇÃO ...............................................................................132

CAPÍTULO 1 - Transigibilidade das controvérsias tributárias .........................132

1.1. Conceito de transação ............................................................................. 132

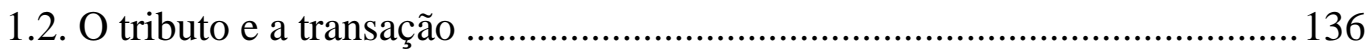

1.3. Transação, o CTN e o crédito tributário como objeto transacionável ........138

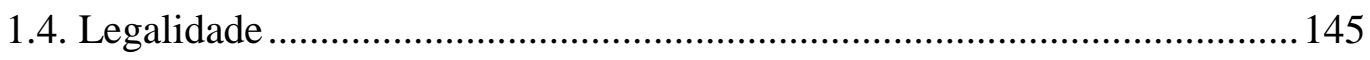

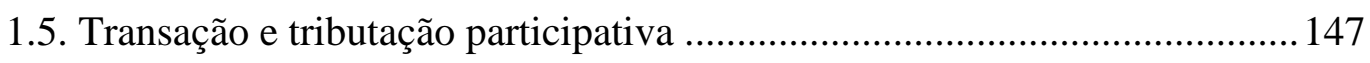

1.6. Os programas para pagamento incentivado de tributos ............................ 151

1.7. A lei de responsabilidade fiscal .............................................................. 154

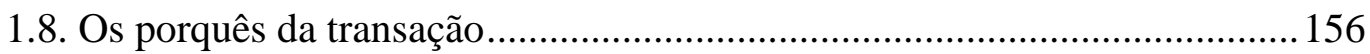


CAPÍTULO 2 - A REGULAMENTAÇÃO DA TRANSAÇÃO 159

2.1. Competência para transacionar 159

2.2. Momento para se instaurar a transação 163

2.2.1. A transação no curso da demanda judicial ......................................... 167

2.2.2. A transação no curso do processo arbitral ........................................ 169

2.3. Aspectos materiais transacionáveis....................................................... 170

2.4. A constituição de crédito em favor do contribuinte a partir da transação... 174

2.5. Âmbito para se processar a transação ........................................................ 176

2.6. A extinção do crédito tributário frente à transação .................................... 177

2.7. A suspensão da exigibilidade do crédito tributário .................................... 179

2.8. Revisão judicial do acordo ..................................................................... 180

2.9. Da possibilidade de se exigir, como condição da transação, que o contribuinte renuncie a discussões judiciais, administrativas e arbitrais do crédito tributário 
Para Rafael.

Razão maior da minha existência e incentivo para todos os desafios. Agradeço incondicionalmente a Deus por me permitir vivenciar tão puro e despretensioso amor. 


\section{AGRADECIMENTOS}

Quando ingressamos num projeto acadêmico que demandará tempo, dedicação, esforço e, sobretudo, serenidade, algumas pessoas acabam, involuntariamente, nos acompanhando. Transmito aqui um singelo agradecimento - que por certo jamais poderá representar toda a gratidão que me acompanhará, para todo o sempre.

Minha família é a razão, a justificativa e o objetivo para tudo o que faço na vida. Agradeço ao André, meu marido, companheiro, amigo e confidente, por todo o apoio, compreensão e também pelas necessárias broncas nos momentos em que foi preciso enfrentar dificuldades. Aos meus pais, Kim e Lu, responsáveis por todos os meus sucessos e que estão ao meu lado em todos os fracassos (esses, por certo, de responsabilidade exclusiva minha), não há palavras para agradecer tudo o que fizeram por mim, desde as difíceis e acertadas escolhas já nos primórdios da minha educação infantil. Vocês são o porto seguro, a imagem e, quem sabe um dia, a semelhança. Ao Christian, irmão, amigo e fiel companheiro de toda a vida, agradeço por estar ao meu lado com apoio incondicional mesmo que eu nem sempre tenha tido razão... E ao Rafael, que mesmo sem qualquer intenção ou objetivo será o maior responsável por todas as minhas vitórias. Meu pequenininho, mamãe acabou, agora ela é toda sua!

Ao meu orientador, Carlos Alberto de Salles, agradeço a paciência, o constante incentivo e, sobretudo, por me mostrar que é possível e preciso acreditar no resultado de uma jornada por vezes desacreditada. Obrigada por me fazer acreditar na academia disposta a inovar, dialogar e compartilhar experiências. Sua dedicação e apoio aos alunos e à comunidade acadêmica demonstram não só a seriedade com que atua nos projetos, mas também a maneira irreparável de construir uma carreira brilhante sem deixar de lado os princípios e valores, sobretudo os familiares. Há pessoas que passam a fazer parte da nossa vida para marcá-la. Você é certamente uma delas. Afinal, orientador é para sempre.

Aos Professores Heleno Taveira Torres e Kazuo Watanabe, agradeço pelos importantes e sempre construtivos comentários feitos durante a banca de qualificação, certamente essenciais à conclusão deste trabalho. 
Muitos compartilharam comigo, desde o início, da empreitada. A Ada Pellegrini Grinover, Carlos Alberto de Salles, João Paulo Hecker da Silva, Hercules Celescuekci, Marco Garcia Lopes Lorencini, Paulo Rogério Sehn, Ricardo Aprigliano e Kazuo Watanabe, agradeço pelo apoio antes mesmo do regular ingresso no programa de pósgraduação da Faculdade de Direito da USP. Seu apoio foi fundamental para a conclusão desse projeto.

Aos Professores Ada Pellegrini Grinover, Marco Garcia Lopes Lorencini, Marcos Vinícius Neder e Kazuo Watanabe, e também aos amigos Marcos Caleffi Pons, Paulo Rogério Sehn e Vanessa Inhasz Cardoso, agradeço pela atenciosa revisão do texto e pelas valiosas opiniões que contribuíram para minimizar os defeitos deste trabalho (estes de minha inteira responsabilidade). Aos meus pais, Antonio e Marilu, agradeço a minuciosa revisão dos aspectos mais formais do texto. Feita com atenção, cuidado e sobretudo, com amor.

Aos colegas do escritório Trench, Rossi \& Watanabe Advogados, especialmente Camila Sayuri Nishikawa, Carolina Martins Sposito, Juliana de Sampaio Lemos e Paulo Rogério Sehn, agradeço pela compreensão nas constantes ausências necessárias à dedicação acadêmica concomitante à nossa já atribulada rotina profissional.

Aos amigos Gláucia Mara Coelho, Gustavo Milaré de Almeida, Leonardo Lusvarghi, Marcos Gomes da Costa e Nathalia Mazzonetto, sou grata por compartilharem da descontração nos intervalos das aulas e pela força nos muitos momentos de dificuldade. Galera, conseguimos!

Na reta final de elaboração, mais uma vez devo agradecer pelo incondicional apoio operacional do André e dos meus pais, Lu e Kim, que cuidaram do pequeno Rafael para que mamãe pudesse concluir o trabalho. Não sei o que seria de mim sem Vocês. 


\section{INTRODUÇÃO}

O tema a ser desenvolvido nesta dissertação de mestrado é a adequação $e$ viabilidade processual da adoção de meios alternativos à solução de controvérsias de natureza jurídico-tributária, com ênfase na arbitragem e transação.

O problema que se propõe é: como utilizar mecanismos consensuais (transação) ou adjudicatórios de base consensual (arbitragem) para soluções de controvérsias tributárias, tendo em vista o regime de indisponibilidade do crédito tributário?

Como hipótese, o estudo sustentará, diante da necessidade de controle dos agentes envolvidos, a necessidade de uma resposta processual que regule a atuação e discricionariedade da Administração Tributária envolvida nesses mecanismos de solução de controvérsias.

No Brasil, métodos consensuais de solução de conflitos são tradicionais e amplamente utilizados em diversas esferas e relações. A própria arbitragem, que ganhou força com o reconhecimento da constitucionalidade da Lei No. 9.307/96, pelo Supremo Tribunal Federal, vem sendo amplamente debatida e estudada pelos cientistas dedicados ao direito processual civil.

De outro lado, a crise do Judiciário é tema corrente não só nos trabalhos científicos ${ }^{1}$ mas também na imprensa especializada. ${ }^{2}$ Medidas vêm sendo adotadas pelo Conselho Nacional de Justiça (“CNJ”) para que os conflitos levados ao judiciário passem a receber tratamento adequado, como, por exemplo, se deu com a edição da Resolução No. 125, que

\footnotetext{
${ }^{1}$ Vale mencionar a análise feita por Rodolfo de Camargo Mancuso ( "A resolução dos conflitos e a função judicial no contemporâneo Estado de Direito”,) sobre a crise do Judiciário, que teria vieses estruturais, organizacionais e conceituais, com o que se recomenda "conscientização dos operadores do Direito e a corajosa mudança de mentalidade de parte dos órgãos e autoridade encarregados do planejamento $e$ avaliação de desempenho da Justiça brasileira” (p. 324).

2 Pesquisa publicada semestralmente pela Fundação Getúlio Vargas mostra que, a despeito de a confiabilidade no Judiciário ser de $42 \%$ dos entrevistados, 93\% das pessoas ouvidas buscam o Judiciário para solucionar conflitos decorrentes de relações com o Poder Público (Relatório IJC Brasil relativo ao $1^{\circ}$ Trimestre de 2012).
} 
prevê política para inserção de mediação e conciliação obrigatórias no âmbito do próprio Judiciário.

A crise enfrentada pelo Poder Judiciário Brasileiro corrobora a necessidade de que se instituam métodos distintos do judicial que sejam viabilizadores de solução (adjudicada consensual ou consensual) de conflitos, como forma de (i) afastar determinadas controvérsias do crivo do Poder Judiciário e, ainda, (ii) promover pacificação social, o que é verificado sobretudo quando se alcança solução consensual para determinada controvérsia.

É justamente nesse sentido que estudos vêm sendo realizados para tratar dos aspectos processuais inerentes às formas tidas por alternativas à judicial para solução de controvérsias, mormente aquelas que envolvem o poder público. ${ }^{3}$

Quanto à delimitação acerca da relação de direito material eleita, a experiência profissional serviu como incentivadora da inquietação originária do problema que se pretende enfrentar.

A possibilidade de o poder público solucionar as controvérsias nas quais se envolve através de meios alternativos de solução de controvérsias, mais especificamente transação e arbitragem, vem sendo amplamente debatida e até mesmo conferida na prática, sobretudo em se tratando de relações contratuais da administração pública. ${ }^{4}$ Tal não ocorre, no entanto, com tanta frequência quanto às controvérsias tributárias.

\footnotetext{
${ }^{3}$ Vale esclarecer o porque da menção a métodos distintos da solução adjudicada judicial de conflitos como sendo alternativos: "The pre-eminence of the court system is such that other forms of dispute resolution are commonly called 'alternative' dispute resolution (or ADR), carring the implication that litigation is the normal first choice” (Susan Blake, Julie Browne e Stuart Sime, A practical approach to alternative dispute resolution, p. 4.

${ }^{4}$ Sobre o tema envolvendo controvérsias da administração pública, vale mencionar as obras de Carlos Alberto de Salles (Arbitragem em contratos administrativos) e de Selma Ferreira Lemes (Arbitragem na Administração Pública. Fundamentos Jurídicos e Eficiência Econômica).
} 
Nesse sentido, a análise da viabilidade da adoção de meios alternativos para solução de controvérsias tributárias, a despeito de encontrar temas comuns às demais controvérsias da administração pública, possui nuances que demandam análise particularizada. ${ }^{5}$

Assim, aliada à opção pela análise dos meios alternativos para solução de controvérsias, o estudo aqui proposto se concentrará nas relações de direito material jurídico-tributárias.

As controvérsias tributárias são notadamente solucionadas em contencioso administrativo ou em medidas judiciais, dentre as quais se destacam ações de execução fiscal, de rito ordinário propostas pelos contribuintes para anulação de crédito tributário ou preventivamente para reconhecimento do direito na adoção de determinada postura, medidas cautelares e, ainda, mandados de segurança.

A própria legislação de regência do processo executivo fiscal é taxativa quanto às hipóteses de discussão judicial do crédito tributário já inscrito em dívida ativa, ou seja, já passível de cobrança judicial (Lei No. 6.830/1980, artigo 38).

Avaliando-se a natureza das causas judiciais em andamento, verifica-se que as demandas que tratam de questões tributárias representam importante parcela das causas levadas ao crivo do Poder Judiciário.

A constante mudança da legislação e normatização tributárias serve de incentivo para que as controvérsias tributárias sejam levadas ao Judiciário em busca de solução, pois inúmeras são as situações de incerteza e até mesmo de restrição de direitos passíveis de questionamento por parte dos contribuintes.

Aliada à diversidade de controvérsias que demanda solução, a morosidade do Judiciário em solucionar as controvérsias acaba agravando ainda mais a situação das demandas tributárias. Veja-se, por exemplo, a questão envolvendo a da ampliação da base de cálculo do PIS e da COFINS perpetrada pela Lei No. 9.718/98: o Supremo Tribunal

\footnotetext{
${ }^{5}$ Acerca da autonomia do direito tributário e do próprio processo tributário, confira-se nosso Coisa Julgada Tributária.
} 
Federal decidiu pela inconstitucionalidade da legislação no ano de 2005, mas desde a vigência da lei (em janeiro de 1999), inúmeras medidas judiciais foram propostas para questionar a legislação e até hoje se arrastam pelas prateleiras dos tribunais.

A efetividade da solução judicial dos conflitos em questão não se mostra satisfatória nem tampouco efetiva. Ademais, frente à complexidade e especificidade das controvérsias em voga, se sugere tratamento especializado e dedicado à sua solução, na medida em que a própria complexidade das relações tributárias atuais traz consequências pontuais e profundas nas relações de direito material que originam conflitos e controvérsias. E o judiciário nem sempre estará apto a produzir, nesses moldes, a solução mais adequada.

No direito alienígena, é usual a possibilidade de se transacionar com o fisco como forma de solucionar conflitos tributários, sendo, em muitos países, incomum a existência de demandas judiciais que tratam de questões tributárias.

Já no Brasil, não há tradição de meios alternativos para solução das controvérsias aqui avaliadas. Há, de fato, divergência doutrinária quanto ao aspecto principal a ser abordado por meio do estudo pretendido - qual seja, a viabilidade processual dos meios alternativos para solução de controvérsias tributárias -, o que corrobora a importância do tema proposto, o qual abordará aspectos relevantes que envolvem o tema, visando à conclusão adequada e fundamentada sobre a questão proposta.

Importante destacar a opção pela análise aprofundada da adoção dos meios que se propõe para solução de controvérsias tributárias internas, não se optando, portanto, pela análise para fins de solução de controvérsias internacionais. Vale mencionar que, em razão da vasta experiência e regulamentação para arbitragem visando à solução de controvérsias tributárias internacionais, serão aproveitados os institutos e casos que possam enriquecer e até mesmo fundamentar as avaliações no tocante aos conflitos internos.

Ademais, sem prejuízo da relevância da mediação e da conciliação, como forma de delimitar o objeto do estudo o mesmo limitar-se-á ao estudo de transação e arbitragem. Sem prejuízo, os demais métodos serão mencionados como paradigma aos objetos centrais do estudo. 
Importante esclarecer que o objetivo do presente estudo não será uma análise profunda dos conceitos e institutos tributários, na medida em que o enfoque a ser conferido é processual. Pela mesma razão, algumas premissas e conclusões são fulcrais à adequada avaliação da viabilidade dos meios processuais estudados à solução das controvérsias eleitas.

Não se pretende através desse estudo esgotar todas as formas não judiciais processualmente aplicáveis à solução de controvérsias tributárias. A opção pelo estudo da arbitragem e transação não afasta a relevância dos demais métodos, mas consiste em opção metodológica viabilizadora da profundidade e seriedade que a dissertação de mestrado exige.

Quanto à transação, a existência de legislação em alguns Estados da Federação e a pendência de projetos de lei (complementar e ordinária) viabilizará uma análise a partir de premissas processuais já postas e, até mesmo, de alguma experiência prática no direito brasileiro.

Acerca da arbitragem, a vasta experiência internacional em solução de controvérsias tributárias por meio de arbitragem, consoante sugestão das regras de tributação internacional para formas de solução de conflitos tributários, trará elementos que enriquecerão o estudo aqui pretendido.

A arbitragem vem sendo tratada cada vez com mais ênfase e causas são levadas à opção alternativa (à adjudicada) para solução de controvérsias não só em razão da melhor qualidade técnica de decisões em casos de elevada complexidade, mas também por força da celeridade necessária à atual dinâmica das relações sociais, econômicas e até mesmo políticas.

Ou seja, a escolha do tema a ser desenvolvido alia o estudo da ciência do direito processual civil às numerosas e complexas relações jurídico-tributárias, com vistas a avaliar, sob o enfoque processual, se a adoção de métodos diversos do judicial seria processualmente adequada para fins de solução de controvérsias tributárias. 
No modelo de Estado contemporâneo não é recente a noção de que ao processo não basta disponibilizar acesso ao judiciário para que haja o adequado tratamento ao conflito. Os próprios princípios constitucionais garantem, além dos direitos inerentes ao processo justo e isonômico (o que se vê mediante a inafastabilidade da jurisdição, da garantia do devido processo legal, do contraditório, da ampla defesa e da coisa julgada - artigo $5^{\circ}$, incisos XXXV, XXXVI, LIV e LV), a determinação de razoável de duração do processo, com o que se conclui que além das garantias usuais é necessário que o processo sirva adequadamente como mecanismo de pacificação social (artigo $5^{\circ}$, inciso LXXVIII).

Especificamente no tocante às controvérsias tributárias o tratamento conferido não tem sido adequado, quer em razão dos inúmeros entraves processuais que se mostram muitas vezes incentivadores ao mau contribuinte, quer por força das demandas repetitivas que assolam os tribunais.

Também a noção de tributação participativa ${ }^{6}$ se encontra em linha com o estudo aqui proposto, na medida em que as relações entre Estado e administrado e, consequentemente, fisco e contribuinte, passam a ser caracterizadas por uma nova roupagem que demanda viabilizar melhores diálogos e maior efetividade.

Justifica-se, assim, a relevância do estudo na atual tendência do processo civil de buscar soluções adequadas às controvérsias e conflitos, levando em conta as nuances da relação jurídico-material ${ }^{7}$ eleita para análise, o que, conforme se demonstrará, não vem sendo satisfatoriamente tratado no âmbito das controvérsias tributárias, na medida em que além da morosidade do Judiciário inerente a todas as demandas em curso, a realidade do contencioso tributário vislumbra a existência de demandas repetitivas intentadas pelos

\footnotetext{
${ }^{6}$ Natalia de Nardi Dacomo avalia a evolução do Direito Tributário e traz a fase participativa como a terceira e atual na linha evolutiva, na qual "caminha-se para um maior envolvimento dos cidadãos e do governo, $e$ consequentemente, para a participação dos contribuintes no processo de positivação do direito" (Direito Tributário Participativo. Transação e arbitragem administrativas da obrigação tributária, p. 45).

${ }^{7}$ Nesse sentido, Carlos Alberto de Salles (Arbitragem em contratos administrativos) traz a instrumentalidade metodológica do processo, em complemento à concepção finalística do instituto. Para o autor, as situações fáticas e de direito material envolvidas são pressuposto para o objeto de estudo do direito processual civil. Assim, conclui o autor pela "necessidade de identificar não apenas um campo específico de direito material, mas também o universo das possíveis situações controvertidas surgidas em relação a uma área determinada. Com isso, é possível formular, de maneira mais acurada, um juízo adequado em relação às medidas processuais cabíveis no caso concreto e, por consequência, do melhor parâmetro interpretativo para as normas de processo" (p. 20).
} 
contribuintes, bem como ineficiência dos meios postos ao dispor do fisco para recuperação de créditos fiscais.

Enfim, o estudo que ora se propõe avaliará a natureza das relações tributárias e os aspectos processuais dos meios alternativos à solução de controvérsias, com ênfase na arbitragem e na transação, de modo a permitir a conclusão acerca da viabilidade ou inviabilidade de sua adoção no campo de direito material eleito, tendo em vista a indisponibilidade do crédito tributário e também a necessidade de se regular a atuação da Administração Tributária.

Nesse contexto é que o presente capítulo introdutório demonstra a importância e relevância do tema frente ao tratamento hodiernamente conferido aos conflitos e controvérsias tributários, inserindo a inquietação originária deste estudo na problemática a ser desenvolvida.

O trabalho se divide em três Partes. A primeira delas tratará dos aspectos gerais que relacionam o direito tributário e o processo civil. A segunda tratará sobre a arbitragem e a terceira, acerca da transação (ocasião na qual será visitada a possibilidade de a mesma se operar no curso do procedimento arbitral).

Assim, no primeiro capítulo da primeira parte, o estudo analisará o status dos processos judiciais tributários em andamento, com ênfase na (i) relevância quantitativa das demandas que tratam de questões tributárias, na (ii) morosidade do Judiciário para solucionar as controvérsias em questão e (iii) da efetividade das formas de solução existentes.

No segundo capítulo, o objetivo será uma análise da controvérsia tributária, bem como do interesse público diante de uma atualizada concepção acerca de sua disponibilidade. Ao final, haverá conclusão acerca da natureza da controvérsia tributária para que, no capítulo seguinte, sejam avaliadas a lide tributária e os instrumentos processuais disponíveis para solucioná-la.

Partindo para a segunda parte do estudo, a análise se centrará na arbitragem, iniciando-se pela avaliação da arbitrabilidade tanto do crédito tributário quanto de 
questões tributárias para, após, análise dos aspectos processuais da arbitragem que se cogita.

Finalmente, na terceira parte do estudo será feita análise da transigibilidade do crédito tributário, bem como da regulamentação da transação e seus aspectos processuais.

Assim, será avaliada a viabilidade da adoção de meios alternativos para solução das controvérsias tributárias frente ao atual modelo Estatal decorrente das transformações havidas na sociedade, o que exerceu relevante interferência na relação entre Estado e administrado, bem como nos anseios da sociedade para uma tributação participativa.

O estudo buscará exemplos na experiência e no direito alienígena e também em normas brasileiras sobre métodos alternativos à solução de controvérsias tributárias, com notas à tendência mundial e estudo de casos já enfrentados. Formulará, outrossim, propostas a partir das necessidades e adaptações específicas do sistema processual à relação jurídica de direito material eleita para estudo.

Diante das anteriores constatações, será apresentada a conclusão final, a qual avaliará ser processualmente adequado e viável, ou não, adotarem-se meios alternativos (arbitragem e transação) para solução de controvérsias tributárias no Brasil.

Em suma, a questão que se propõe é: diante do cenário brasileiro atual, é processualmente adequada e viável a adoção de arbitragem e transação, na qualidade de meios adjudicatório consensual e consensual, alternativos ao judicial, para solução de controvérsias tributárias? 


\section{PARTE I - DIREITO TRIBUTÁRIO E PROCESSO}

\section{CAPÍTULO 1 - UM RETRATO DOS PROCESSOS JUDICIAIS TRIBUTÁRIOS}

As estatísticas dos tribunais mostram que o Poder Público é litigante na maioria dos processos judiciais distribuídos ${ }^{8} \mathrm{e}$, ainda, que as controvérsias tributárias representam parcela expressiva das demandas em andamento no Brasil.

De outro lado, numa análise setorial, a efetividade das soluções produzidas a partir da solução judicial das controvérsias tributárias mostra que não se alcançam objetivos e nem tampouco resultados satisfatórios.

Questiona-se, assim, se os instrumentos postos à disposição da administração pública e dos administrados para solução de controvérsias tributárias possuem a efetividade necessária ao atendimento dos anseios sociais, bem como se os resultados atingidos são eficientes e satisfatórios.

Dados mostram que o processo executivo fiscal no Brasil não produz resultados satisfatórios no tocante à recuperação de crédito tributário constituído em favor das diversas esferas do fisco nacional (federal, estadual, municipal, territorial e do Distrito Federal).

\footnotetext{
${ }^{8}$ Recente estudo do Conselho Nacional de Justiça sobre os cem maiores litigantes nos tribunais brasileiros mostra que os seis maiores, presentes em 53,73\% dos processos distribuídos, são entes públicos, a saber: Instituto Nacional do Seguro Social (presente em 22,33\% dos processos), Caixa Econômica Federa, (8,5\% dos processos), Fazenda Nacional (7,45\% dos processos), União Federal (6,97\% dos processos), Banco do Brasil e Estado do Rio Grande do Sul (presentes em 4,24\% dos processos cada um).

A pesquisa constatou ainda que demandas envolvendo os setores públicos federal, estadual e municipal representam $51 \%$ das ações distribuídas no país (vale destacar que os Bancos representam 38\% das ações e, dentre estas, há ações envolvendo Bancos públicos).

Ou seja, muito embora a análise não tenha sido feita por matéria em discussão, mas sim sobre as partes litigantes, fica evidente que o próprio Poder Público é responsável por parcela representativa das demandas julgadas pelo Judiciário. (Disponível em <http://www.cnj.jus.br/images/pesquisasjudiciarias/pesquisa_100_maiores_litigantes.pdf.>)
} 
Confira-se quadro, que apresenta o valor total da dívida ativa registrada pelo fisco federal entre os anos 2000 e $2007:^{9}$

MINISTÉRIO DA FAZENDA

TADA DA FAZNDA NACIONAL-PGFN

DORDENAÇAO-GERAL DA DIVIDA ATNA DA UNIAO - CDA

\section{ESTOQUE TOTAL DA DÍVIDA ATIVA DA UNIÃO (VALOR DAS INSCRIÇOES EM COBRANÇA)}

\begin{tabular}{|c|c|c|c|c|}
\hline & AJUIZADAS & NÁO AJUIZADAS & TOTAL & VARAAÇĀO \\
\hline ATÉ DEZ/2000 & $114.129 .083 .962,01$ & $11.551 .260 .390,33$ & $125.680 .344 .352,34$ & \\
\hline ATÉ DEZ/2001 & $123.947 .873 .713,18$ & $26.880 .257 .517,82$ & $150.828 .131 .231,00$ & $20,01 \%$ \\
\hline ATÉ DEZ/2002 & $158.460 .044 .612,83$ & $15.715 .242973,64$ & $174.175 .287 .586,47$ & $15,48 \%$ \\
\hline ATÉ DEZ/2003 & $192.951 .792 .078,29$ & $18.407 .565 .566,67$ & $211.359 .357 .644,96$ & $21,35 \%$ \\
\hline ATÉ DEZ/2004 & $237.027 .915 .611,81$ & $24.930 .437 .352,89$ & $261.958 .352 .964,70$ & $23,94 \%$ \\
\hline ATÉ DEZ/2005 & $295.947 .017 .219,93$ & $38.186 .118 .370,21$ & $334.133 .135 .590,14$ & $27,55 \%$ \\
\hline ATÉ DEZ/2006 & $376.447 .594 .102,14$ & $25.231 .064 .053,19$ & $401.678 .658 .155,33$ & $20,22 \%$ \\
\hline ATÉ DEZ/2007 & $459.304 .684 .210,50$ & 23.049.507.359,42 & $482.354 .191 .569,92$ & $20,08 \%$ \\
\hline ATÉ AGOSTO / 2008 & $500.306 .233 .009,50$ & $28.305 .557 .853,75$ & $528.611 .790 .863,25$ & $9,59 \%$ \\
\hline
\end{tabular}

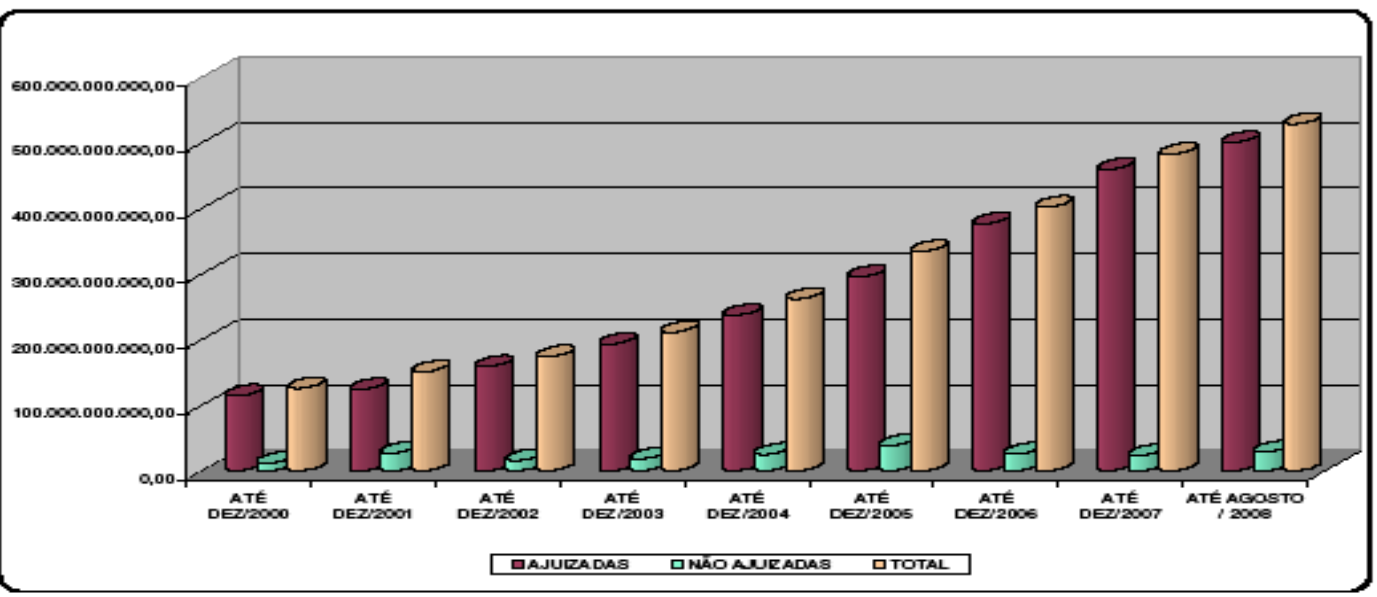

${ }^{9}$ Fonte:http://www.pgfn.fazenda.gov.br/publicacoes/estatisticas-da-divida-ativa-dauniao/ESTOQUE\%20D.A.U\%20-\%20VALOR.pdf/. 
Como se vê, o valor da dívida ativa federal vem crescendo desde 2000: o salto é de aumento de 20,01\% entre os anos de 2000 e 2001, alcançando-se crescimento de quase $28 \%$ entre os anos de 2004 e 2005.

Especificamente no âmbito federal no mês de dezembro do ano de 2006, o valor das dívidas ativas registradas totalizava o montante de $\mathrm{R} \$ 401.678 .658 .155,33$ (quatrocentos e um bilhões, seiscentos e setenta e oito milhões, seiscentos e cinquenta e oito mil, cento e cinquenta e cinco reais e trinta e três centavos) ${ }^{10}$.

Já o valor recuperado via cobrança judicial naquele ano atingiu o equivalente a $\mathrm{R} \$ 2.434 .490 .731,96^{11}$ (dois bilhões, quatrocentos e trinta e quatro milhões, quatrocentos e noventa mil, setecentos e trinta e um reais e noventa e seis centavos), ou seja, aproximadamente $0,6 \%$ do total acumulado.

Em contrapartida, os dados da arrecadação anual da dívida ativa da União Federal desde o ano $2000^{12}$, muito embora mostre um aumento do montante arrecadado a partir do ano de 2005, não mostra números satisfatórios se comparados aos valores totais inscritos:

\footnotetext{
${ }^{10}$ Fonte:http://www.pgfn.fazenda.gov.br/publicacoes/estatisticas-da-divida-ativa-dauniao/ESTOQUE\%20D.A.U\%20-\%20VALOR.pdf/.

${ }^{11}$ Fonte:http://www.pgfn.fazenda.gov.br/publicacoes/estatisticas-da-divida-ativa-dauniao/ARRECADACaO\%20ANUAL\%20DA\%20D.A.U.pdf/, excluindo-se os valores equivalentes ao arrecadado em razão dos programas de recuperação fiscal (REFIS e PAES), bem como os valores decorrentes de arrecadação bruta da Defesa Nacional.

${ }^{12}$ Fonte:http://www.pgfn.fazenda.gov.br/publicacoes/estatisticas-da-divida-ativa-dauniao/ARRECADACaO\%20ANUAL\%20DA\%20D.A.U.pdf/.
} 
MINISTÉEIO DA FAZENDA

DATENDA NACIONNLL - PGFN

COORDENAC,AO-GEPAL DA DIVIDA ATINA DA UNIAO - CDA

\section{ARRECADAÇÃO ANUAL DA DÍVIDA ATIVA DA UNIÃO}

\begin{tabular}{|c|c|c|c|c|c|c|}
\hline ANO & D.A.U & REFIS ${ }^{(1)}$ & PAES ${ }^{\circ}$ & DEFESA & TOTAL & $\begin{array}{l}\text { VARIACACAO } \\
\text { ANUAL. }\end{array}$ \\
\hline 2000 & $1.455 .655 .063,47$ & $349.169 .649,18$ & - & $2.868 .140 .198,30$ & $4.672964,900,95$ & \\
\hline 2001 & $1.042510 .300,75$ & $598.397 .315,01$ & - & 4.369.305.964,57 & $6010.213 .590,33$ & 28,629 \\
\hline 2002 & $1.376 .365 .896,62$ & $556.680 .423,61$ & - & 4.874.,305.092,35 & $6.907 .351 .400,58$ & $13,26 \%$ \\
\hline 2003 & $910.100 .175,12$ & $464.181 .753,52$ & $552.294 .943,04$ & $5.332 .538 .569,40$ & $7.259 .115 .461,08$ & $6,64 \%$ \\
\hline 2004 & $996.905 .049,28$ & $133.349 .960,89$ & 1.112,307.393,75 & 6.198.204.356,12 & $8.440 .786 .760,02$ & $16,28 \%$ \\
\hline 2005 & 1.628.312.870,31 & $70.714 .359,03$ & $923.393 .086,56$ & $7.232,186.632,21$ & $9.854 .606 .948,11$ & $16,75 \%$ \\
\hline 2006 & $2434.490 .731,96$ & $125.890 .962,38$ & $443.010 .200,62$ & $7.959 .041 .674,87$ & $10.962,432,469,83$ & $11,24 \%$ \\
\hline 2007 & $2922048.687,82$ & $101.628 .528,70$ & $662.289 .253,51$ & $9.206 .782,994,81$ & $12.892,755,464,84$ & $17,61 \%$ \\
\hline ATE AGOSTO / 2008 & 1.913.554.325,37 & $63.893 .309,64$ & $700.410 .361,74$ & $6.039 .209 .111,63$ & $8.717 .067 .108,38$ & \\
\hline TOTAL & $14.679 .943 .090,68$ & $2.463 .906 .161,96$ & 4.392 .705 .239 .22 & $54.079 .720 .604,26$ & $75.617 .275 .096,12$ & \\
\hline
\end{tabular}

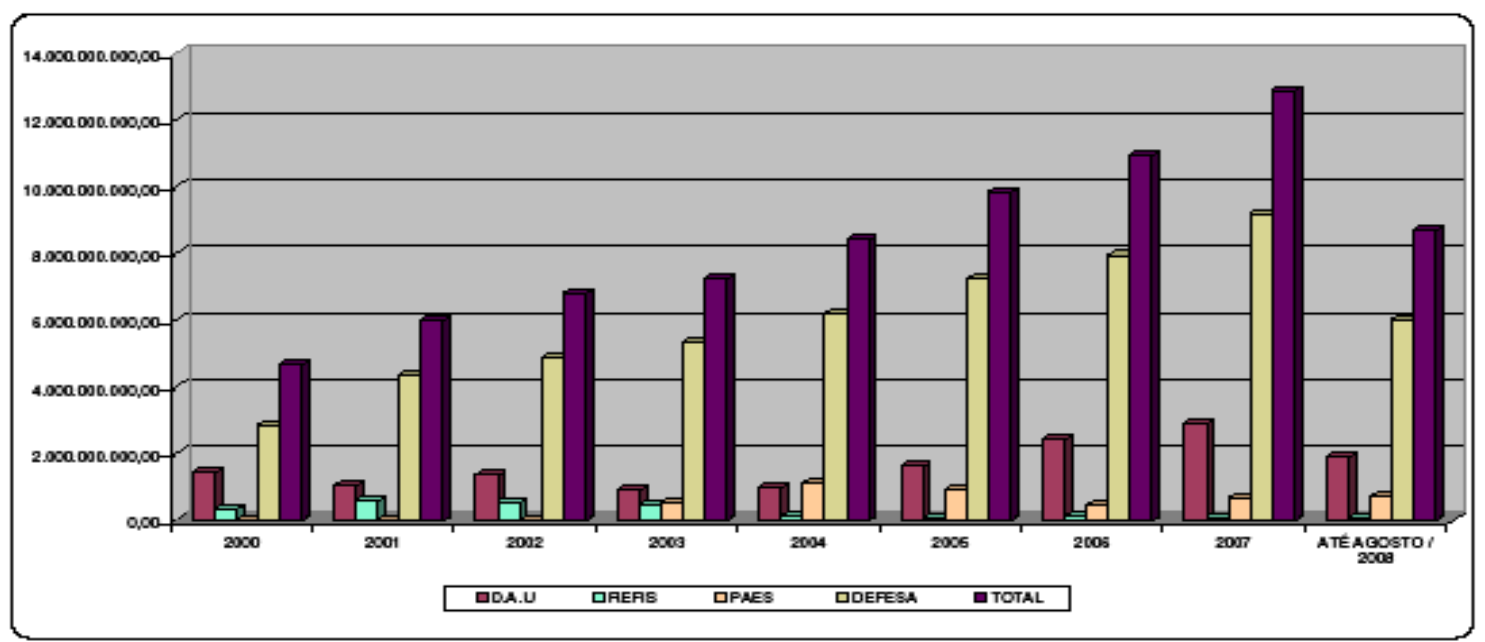

Analisa-se no quadro acima, por exemplo, que no ano de 2002, do total inscrito em dívida ativa correspondente a $\mathrm{R} \$ 174.175 .287 .586,47$ recuperou-se, via defesa ${ }^{13}$, $\mathrm{R} \$$ 4.074.305.092,25, o que equivale ao ínfimo percentual de 2,34\%.

${ }^{13}$ Excluem-se os valores arrecadados por força dos programas de anistia fiscal (PAES e REFIS), bem como os pagamentos feitos espontaneamente pelos contribuintes, eis que referidas receitas não decorrem de sucesso nas ações executivas fiscais. 
Em contraposição à sua baixa efetividade, o processo de execução fiscal representa parte significativa das demandas distribuídas perante a Justiça Federal, conforme levantamento feito pelo Conselho da Justiça Federal (“CJF”).

Verifica-se que perante a Seção Judiciária Federal de São Paulo, no mês de agosto de 2008 , havia $1.537 .136^{14}$ processos em andamento, dos quais, conforme levantamento do CJF, $989.486^{15}$ correspondiam a ações de execução fiscal, o que equivale a aproximadamente $64 \%$ do total das medidas em tramitação ${ }^{16}$.

Os dados ilustram a realidade dos processos judiciais tributários no Brasil intentados pelo Poder Público: grande número de demandas em andamento com reduzida eficiência, na medida em que a recuperação, pelo fisco, do crédito tributário, é manifestamente insatisfatória. ${ }^{17}$

No entanto, o levantamento fático não inclui as causas cíveis que tratam de matéria tributária, o que certamente ampliaria a participação dos processos judiciais federais propostos para solução de controvérsias tributárias.

Cumpre salientar que impresso divulgado pela própria Procuradoria da Fazenda Nacional mostra que durante o ano de 2011, recuperou-se via cobrança judicial $1,37 \%$ do valor total inscrito em dívida ativa, comemorando resultado que "representa um aumento de 121,45\% da efetividade da arrecadação da dívida ativa em relação ao ano anterior". 18

\footnotetext{
${ }^{14}$ Fonte: http://www.trf3.jus.br/trf3r/index.php?id=917, acesso em 01.11.09.

${ }^{15}$ Fonte: http://daleth.cjf.jus.br/atlas/Internet/Execucao_Fiscal_arquivos/sheet001.htm, acesso em 12.12.09.

${ }^{16}$ Vale destacar que o percentual considera apenas executivos fiscais, não havendo levantamento de medidas ajuizadas pelos contribuintes para discussão de mérito tributário.

${ }^{17}$ Há estudos que analisam a situação específica da recuperação judicial do crédito tributário, à exemplo do Estudo sobre Execuções Fiscais no Brasil, promovido pela Secretaria de Reforma do Judiciário do Ministério da Justiça, com apoio do Centro Brasileiro de Estudos e Pesquisas Judiciária (CEBEPEJ). Após analisar estatisticamente a questão dos processos executivos fiscais no Brasil, o estudo traz sugestões específicas para maior efetividade do procedimento, tais como a desnecessidade de penhora para discussão do crédito tributário, a possibilidade de penhora administrativa, a existência de oficiais de justiça ad hoc, a obrigatoriedade de indicação de bens passíveis de penhora na petição inicial, a simplificação na forma de quitar os débitos ajuizados e, finalmente, a manutenção da atual lei de execuções físcais, como alterações meramente pontuais.

${ }^{18}$ A PGFN em números, disponível em www.pgfn.gov.br/noticias/PGFN\%20Em\%20Numeros\%20-

$\% 202011 . p d f$, acesso em 20.03.2012.
} 
Considerando o orçamento da Procuradoria-Geral da Fazenda Nacional ${ }^{19}$ e ainda as expensas estatais para manutenção dos fóruns e Varas especializados em ações de execução fiscal federal, verifica-se a baixa produtividade e ínfima efetividade na medida em que os resultados não se mostram satisfatórios se levado em contrapartida ao investimento da Sociedade para viabilizar a arrecadação.

Inédito estudo do IPEA sobre o Custo Unitário do Processo de Execução Fiscal na Justiça Federal $^{20}$ apontou que o custo unitário do processo de Execução Fiscal federal, considerando tão somente a máquina judiciária (ou seja, excluindo-se a remuneração dos advogados públicos) chega a $\mathrm{R} \$ 4.368,00$ (custo ponderado da remuneração dos servidores em face do tempo operacional das atividades efetivamente realizadas, considerados o tempo que o caso fica parado e também a mão de obra indireta).

No entanto, a despeito do elevado custo unitário, a efetividade da solução através das ações executivas fiscais não é satisfatória também em decorrência dos parâmetros apontados pelo IPEA/CNJ.

Apenas três quintos dos processos de execução fiscal vencem a etapa de citação e, dos 2,6\% de casos em que se chega a leilão para adjudicação de bens, somente em $0,2 \%$ dos casos há efetiva satisfação do crédito, segundo o IPEA/CNJ.

O percentual de ações executivas que deságuam no pagamento do débito é similar àquele relativo às decretações de prescrição da ação $(33,9 \%$ e $27,7 \%$, respectivamente). Ainda, em $17 \%$ dos casos a dívida é cancelada pelo próprio Exequente, o que torna evidente que a soma dos casos extintos por prescrição e cancelamento de dívida supera o percentual de casos que resultam em efetiva arrecadação ao Erário.

Em contrapartida abaixa eficiência das ações de execução fiscal, dados dos tribunais superiores mostram que as ações tributárias representam relevante parcela do total de recursos aguardando julgamento.

19 O Relatório Gestacional da Procuradoria Geral da Fazenda Nacional aponta orçamento no valor de $\mathrm{R}$ \$ 474.350.657,00 no ano de 2011 e, em contrapartida, a arrecadação de valores inscritos em dívida ativa alcançou R\$ 13,6 bilhões (informação disponível em http://www.pgfn.fazenda.gov.br/institucional/relatoriode-gestao, aceso em 09.10.2012).

${ }^{20}$ Relatório publicado pelo IPEA e CNJ em Brasília, 2011. 
Levantamento realizado pelo Supremo Tribunal Federal mostra que as ações tributárias e previdenciárias representam $15,47 \%$ do total dos recursos em andamento perante a Corte (dados atualizados até setembro de 2009). Já no ano de 2012, esse percentual alcançou 22,31\% dos recursos autuados no Supremo Tribunal Federal (“STF”).

Ainda, verifica-se aumento da parcela de recursos tributários: no ano 2000 representavam 5,76\% do total dos recursos em andamento; já em 2008, as ações tributárias representavam 20,94\% dos recursos ${ }^{21}$ e em 2011, 10,63\%. A despeito da redução percebida após o ano de 2008, verifica-se relevante aumento se considerado o índice do ano 2000.

Marcos Vinícius Neder e Maria Teresa Martinez Lopes ${ }^{22}$ ressaltam a relevante participação da matéria tributária nos processos pendentes de julgamento perante o STF e, sobretudo, à existência de sub judice questões "de massa". Empresando manifestação do Ministro Gilmar Mendes, os autores tratam da necessária adoção de "mecanismos de prevenção que antecipem a solução dos litígios de massa e evitem a chegada dessas questões na Suprema Corte".

Em adição ao acima exposto, dois aspectos merecem ser analisados com cautela para reforçar a ineficácia e ineficiência dos remédios postos à disposição dos contribuintes e dos fiscos em se tratando de questões tributárias: a notória morosidade do Judiciário para julgar demandas e os elevados custos do processo $^{23}$, os quais compreendem não apenas custas e emolumentos, mas também dispêndios (i) com honorários de advogados e (ii) despesas e ações decorrentes da existência de medida judicial que questione o crédito tributário $^{24}$.

21 Fonte: http://www.stf.jus.br/portal/cms/verTexto.asp?servico=estatistica\&pagina=pesquisaRamoDireito, acesso em 01.11.09 e em 09.10.12.

${ }^{22}$ Processo administrativo fiscal federal comentado, p. 50.

${ }^{23}$ No tocante aos elevados custos do processo judicial, vale destacar que o fator é apontado por inúmeros doutrinadores como aspecto que inibe a propositura de ações inclusive para pleito dos direitos transindividuais (processos coletivos). Nesse sentido, vale citar Carlos Alberto Salles, in Políticas Públicas e a Legitimidade para defesa dos interesses difusos e coletivos; no direito alienígena, Neil Komesar, in Law's limits, afirma "depending on factors such as the distribution of social losses [...] and the cost of litigation, the deterrence impacts of court pricing through the damage remedy can be severely impaired", (p. 42 e ss).

${ }^{24}$ A experiência profissional no patrocínio de demandas tributárias mostra que aliadas à existência do processo judicial há inúmeras medidas e providências necessárias por parte de contribuintes pessoas jurídicas que viabilizem o exercício de suas atividades. Em se tratando de causas tributárias, vale lembrar por exemplo que muitas vezes ações externas ao processo são necessárias para viabilizar emissão de certidões negativas (artigos 205 e 206 do Código Tributário Nacional). 
Ou seja, mostra-se ineficaz e inadequado o sistema ${ }^{25}$ no que tange à satisfatória solução das controvérsias tributárias, como acima demonstrado. Resta, desse modo, avalizar se a adoção de meios alternativos à solução das controvérsias é adequada à relação jurídica de direito material eleita para análise.

${ }^{25}$ Sobre a crise mundial do Judiciário, que afeta não só o Brasil, mas também os países desenvolvidos na Europa, ver análise de Humberto Theodoro Júnior, Celeridade e efetividade da prestação jurisdicional. Insuficiência da reforma das leis processuais, p. 68-70. 


\section{CAPÍTULO 2 - A CONTROVÉRSIA TRIBUTÁRIA FRENTE À ATUAL CONCEPÇÃO DO INTERESSE PÚBLICO}

A globalização e a informatização decretaram significativas mudanças no modelo de Estado atual, quer no tocante à sua relação com os cidadãos, quer acerca da relação intraestatal e até mesmo entre os Estados nacionais.

Tais mudanças interferem diretamente na maneira de compreender a natureza jurídica dos institutos de direito público, dentre os quais se insere a própria controvérsia tributária. É o que se passa a analisar.

\subsection{Nova conjuntura econômica, social e política: justificativa e premissa para mudanças}

Internamente, o Estado deixou de ser provedor dos serviços essenciais, na medida em que compartilha tal tarefa com o setor privado e atua como regulamentador dos serviços - o que faz, muitas das vezes, através de agências reguladoras.

Nos Estados Unidos da América, a doutrina que estuda os papéis e funções do Estado chega a mencionar a necessidade de que seja desenvolvida uma teoria para análise do aumento de administradores privados e auditores na qualidade de uma nova geração de administradores públicos. ${ }^{26}$

Nesse novo cenário, a noção tradicional de direito público e a dicotomia público $\mathrm{X}$ privado perde importância, na medida em que aspectos tradicionalmente tratados por normas de direito público são, atualmente, de responsabilidade de entes privados e, portando, regulamentadas por norma que cuidam das relações entre particulares.

${ }^{26}$ Harold Seidman e Robert Gilmour, Politics, position and Power, p. 122. 
De outro lado, com a internacionalização da economia as decisões internas de um Estado exercem influência no mercado e nas relações mundiais e as fronteiras deixam de representar limites para determinadas relações e transações. O surgimento de blocos econômicos e relações nunca dantes verificadas igualmente determinam que o direito se modernize e possa regulamentar situações absolutamente imprevisíveis.

Nesse modelo, o direito deverá ser capaz de regular situações mesmo que não as tenha previsto e, para tanto, cada vez mais as formas não tradicionais de solução de controvérsias se mostram adequadas e necessárias na medida em que capazes de trazer soluções criativas, no tempo atual da sociedade.

Normas jurídicas que levem tempo a se modernizar e adaptar às transformações econômico-sociais tem seus dias contados na medida em que a sociedade, no atual nível informacional e globalizado, demanda por regulamentos capazes de acompanhar a velocidade das relações e transformações.

As transformações no modelo de Estado, decorrentes da nova conjuntura econômica e social, majoritariamente inerentes ao Estado informacional, ${ }^{27}$ sugere uma releitura da concepção tradicional da indisponibilidade do interesse público e do crédito

27 A opção por referência ao Estado e à sociedade como informacional tem origem na teoria de Manuel Castells, Sociedade em Rede:

Uma nova economia surgiu em escala global nas duas últimas décadas. Chamo-a de informacional e global para identificar suas características fundamentais e diferenciadas e enfatizar sua interligação. É informacional porque a produtividade e a competitividade de unidades ou agentes nessa economia (sejam empresas, regiões ou nações) dependem basicamente de sua capacidade de gerar, processar e aplicar de forma eficiente a informação baseada em conhecimentos. É global porque as principais atividades produtivas, o consumo e a circulação, assim como seus componentes (capital, trabalho, matéria-prima, administração, informação, tecnologia e mercados) estão organizados em escala global, diretamente ou mediante uma rede de conexões entre agentes econômicos. É informacional e global porque, sob novas condições históricas, a produtividade é gerada, e a concorrência é feita em uma rede global de interação. E ela surgiu no último quartel do século XX porque a Revolução da Tecnologia da Informação fornece a base material indispensável para essa nova economia, seu alcance global e a Revolução da Tecnologia da Informação que cria um novo sistema econômico distinto”.(p. 87). Mais adiante, “A economia informacional é um sistema socioeconômico distinto em relação à economia industrial, mas não devido a diferenças nas fontes de crescimento de produtividade. Em ambos os casos, conhecimentos e processamento da informação são elementos decisivos para o crescimento econômico, como pode ser ilustrado pela história da indústria química com base científica ou pela revolução administrativa que criou o Fordismo. O que é característico é a consequente realização do potencial de produtividade contido na economia industrial madura em razão da mudança para um paradigma tecnológico baseado em tecnologias da informação. O novo paradigma tecnológico mudou o escopo e a dinâmica da economia industrial, criando uma economia global e promovendo uma nova onda de concorrência entre os próprios agentes econômicos já existentes e também entre eles e uma legião de recém chegados. (p. 109). 
tributário, como assim dos meios que o poder público poderá utilizar para solucionar as controvérsias nas quais se vê envolvido.

A relevância da característica informacional do Estado $^{28}$ se torna relevante na medida em que, aliada à internacionalização, a informatização é fator determinante no que se refere à nova ordem. ${ }^{29}$

No contexto atual, muito se tem estudado e comentado sobre a crise do modelo de Estado. Não basta mais a noção de Estado voltado às suas próprias necessidades institucionais, que concentra esforços na manutenção da morosa e burocrática máquina estatal: o Estado deve estar voltado aos anseios e necessidades dos cidadãos e, para tanto, a internacionalização da economia e das relações, e também a informatização, são aspectos intrínsecos dessa nova perspectiva.

Uma das facetas da crise dos Estados é interna, ou seja, verificada dentro dos limites territoriais e realidades de cada um, tanto na relação com os administrados como nas próprias relações entre os agentes estatais, e para superá-la, é corrente a busca por novos modelos ${ }^{30}$.

${ }^{28}$ Acerca da sociedade informacional e global, vale transcrever mais uma vez o entendimento de Casstels, para quem "Uma nova economia surgiu em escala global nas duas últimas décadas. Chamo-a de informacional e global para identificar suas características fundamentais e diferenciadas e enfatizar sua interligação. É informacional porque a produtividade e a competitividade de unidades ou agentes nessa economia (sejam empresas, regiões ou nações) dependem basicamente de sua capacidade de gerar, processar e aplicar de forma eficiente a informação baseada em conhecimentos. É global porque as principais atividades produtivas, o consumo e a circulação, assim como seus componentes (capital, trabalho, matéria-prima, administração, informação, tecnologia e mercados) estão organizados em escala global, diretamente ou mediante uma rede de conexões entre agentes econômicos. É informacional e global porque, sob novas condições históricas, a produtividade é gerada, e a concorrência é feita em uma rede global de interação. E ela surgiu no último quartel do século XX porque a Revolução da Tecnologia da Informação fornece a base material indispensável para essa nova economia, seu alcance global e a Revolução da Tecnologia da Informação que cria um novo sistema econômico distinto." (Sociedade em rede, p. 87).

${ }^{29}$ A internet pode criar vias alternativas de participação e consegue fomentar o debate político e a democracia em escala mundial. De outro lado, o acesso à internet é disponível somente a uma minoria da população e, ainda, a comunicação via internet pode ser prejudicada em razão de parte da população não dominar a leitura e a escrita. Assim, recomenda-se que antes de pensar na internet como uma solução para fomento e aprimoramento da democracia, é preciso adotar políticas que disseminem seu uso por todos os cidadãos. Nesse sentido, Marie Jose Garot, De La administracion electronica a uma democracia digital, p. 89-98.

${ }^{30}$ Uma análise interessante da crise que os Estados atuais enfrentam é feita por Canotilho 'Constitucionalismo e geologia da good governance) ao destacar que o Estado deve se pautar na garantia dos direitos individuais dos cidadãos e, para tanto, traz a noção de good governance, a qual deve sempre estar vinculada à accountability e à responsiveness. 
A nova gama de relações que são abrangidas por normas de direito público e aquelas objeto das tradicionais regras de direito privado demanda uma profunda análise da responsividade (responsiveness) das normas jurídicas frente às atuais relações dos Estados perante outras unidades de poder e também perante seus administrados ${ }^{31}$.

Bob Jessop, ${ }^{32}$ em estudo sociológico sobre a temática, concluiu que a crise do modelo de Estado Keynesiano se agravou, sobretudo, por força da globalização, na medida em que passou a ser muito complicado desenvolver-se a economia nacional tendente a medidas para eliminar o desemprego, manter a estabilidade de preços, o crescimento da economia e ainda um viável balanço dos pagamentos. ${ }^{33}$

Também as crises internas dos Estados nacionais (mais especificamente as crises social e política) levaram ao colapso do Estado Keynesiano de Bem-Estar social, o que, no entender de Bob Jessop ${ }^{34}$, iniciou uma mudança baseada primordialmente em três tendências: desestatização, desnacionalização e internacionalização.

Quanto à desestatização, Jessop fala na transição de um governo centralizado para formas mais descentralizadas de governo, o que inclui parcerias com organizações oficiais, paraestatais e não governamentais para fins de gerenciamento das relações econômicas e sociais. ${ }^{35}$

${ }^{31}$ Para Odete Medauar, as transformações em tela decorrem do neoliberalismo, ou seja, é uma "disciplina macroeconômica, economia de mercado, abertura comercial”, que levou ao fortalecimento dos mercados privados, desregulamentação da economia, privatização das empresas estatais, liberalização dos mercados, livre comércio internacional, redução da atuação do Estado, controle da inflação, redução do déficit público e corte das despesas sociais ( $O$ direito administrativo em evolução, p. 124-136).

${ }^{32}$ Narrating the future of national economy and national State? Remarks on remaping regulation and the reinventing governance, p. 5.

${ }^{33}$ Ainda sobre a crise do Estado keynesiano, Giandomenico Majone ressalta que o papel beneficente do Estado positivo como planejador, produtor direto de bens e serviços e também como empregador desmoronou e, na mesma linha da teoria econômica das falhas de mercados, a Public Choice avalia as falhas de governo e define as escolhas públicas (Do estado positivo ao estado regulador: causas e consequências da mudança no modo de governança, p. 53-63).

Nesse sentido, como ensina Eduardo Talamini, surge o modelo de Estado regulador, caracterizado por privatizações, desregulação e liberalização (in A (in)disponibilidade do interesse público: consequências processuais, p. 56-68).

${ }^{34}$ Narrating the future of national economy and national State., p. 15.

35 Tradução livre a partir do original: "movement from the taken-for-granted necessity of varied forms and levels of partnership between official, parastatal, and nongovernmental organizations in managing economic and social relations" (op cit., p. 8). 
No atual contexto, o cidadão deixa de ser portador de direitos políticos e se torna consumidor de bens e serviços que eram, primordial e exclusivamente, fornecidos pelo Estado $^{36}$, o que, necessariamente, acaba por alterar substancialmente tanto a relação entre cidadão e Estado, como a relação do cidadão com o fornecedor desses serviços.

Vale uma pausa para avaliar as transformações havidas no Estado brasileiro. Abrucio $^{37}$ traça a trajetória da administração pública brasileira nos últimos 20 anos, apontando avanços e inovações verificados no período.

O autor inicia tratando do período de redemocratização (ou seja, pós ditadura militar) até o início do governo Lula. Ressalta que a preocupação dos agentes da reforma seria corrigir os erros cometidos pelos militares, não havendo real preocupação na construção de um Estado “capaz de enfrentar os novos desafios históricos”. Menciona, ainda, as importantes reformas nas finanças públicas havidas no final da década de 1980, mas ressalta que as mudanças mais profundas se deram com a Constituição Federal de 1988: democratização do Estado, com controle externo da administração pública, descentralização e reforma do serviço civil (com a profissionalização da burocracia). No entanto, o autor aponta falhas ocorridas que impediram a efetiva concretização dessas mudanças, dentre as quais vale ressaltar o federalismo compartimentado que foi criado.

Nesse cenário, ao final da década de 1990 incentivada o funcionalismo público focado nos benefícios do final da carreira (aposentadoria integral e vitalícia) e, enfim, veio a era Collor, com seu conceito de governo de marajás e idéia de Estado mínimo. O que se verificou, de fato, foi o desmantelamento de diversos setores e políticas públicas, além de redução de atividades estatais essenciais.

Após, a era Fernando Henrique Cardoso (“FHC”), marcada, como diz Abrucio, pela construção de uma nova gestão pública: continuação e aperfeiçoamento da civil service reform (reorganização administrativa do governo federal, fortalecimento das carreiras de Estado), além de mudanças na área legal (políticas para restrição orçamentária e otimização de políticas). Finalmente surgem novas formas de gestão: modelo gerencial de Bresser-Pereira, ou seja, o modelo de administração voltada para resultados.

\footnotetext{
${ }^{36}$ Nesse sentido, ver Kuntz, O poder como direito e outros estudos de filosofia política, p. 170.

${ }^{37}$ Trajetória recente da gestão pública brasileira, p. 68.
} 
Surge, nesse momento, um espaço público não estatal (Oscips, OSs e, após, as PPPs) mas, apesar dos avanços, a era Bresser em muitos aspectos fracassou. O autor aponta três justificativas principais para o fracasso: legado negativo da era Collor, o próprio histórico das reformas administrativas no Brasil e a prevalência da equipe econômica e de seu pensamento na lógica do governo FHC. $^{38}$

Já o segundo governo FHC teria sido marcado pelo empobrecimento da gestão pública. O autor destaca cinco movimentos: questão fiscal, novidades no campo das políticas públicas diante da maior participação social, bem como inovações na área das políticas públicas, coalizão em torno do Plano Plurianual e idéia de planejamento e o governo eletrônico (considerado o mais significativo).

Enfim, o autor passa a tratar do governo Lula, que continuou diversas iniciativas do governo anterior, mas o autor afirma tenha sido marcado pela incapacidade de estabelecer uma agenda em prol da reforma da gestão pública, sobretudo em razão do loteamento dos cargos públicos e da falta de uma visão integrada e de longo prazo para a gestão pública brasileira. No entanto, o autor ressalta que o governo deixa como legado importantes avanços nos mecanismos de combate à corrupção, bem como reformas importantes no plano federativo (Pnage, Promoex,Pnafe, CDES).

Entre idas e vindas, há na história recente do Brasil avanços, mas também aspectos que ainda demandam mudanças viscerais na execução do Estado que plenamente atende o atual anseio da sociedade informacional.

Por conseguinte, as normas jurídicas que passarão a permear determinados serviços e necessidades dos cidadãos igualmente sofrerão importante mudança, sobretudo na medida em que aspectos tradicionalmente sob e égide de regras de direito público passam a ser permeadas por normas regulamentares de relações privadas.

\footnotetext{
${ }^{38}$ Em resumo, Abrucio afirma que "as condições políticas prejudicaram a reforma Bresser” ( p. 73), pois “a nova gestão pública tem uma série de peculiaridades que dizem respeito à necessidade de se ter instrumentos gerenciais e democráticos novos para combater os problemas que o Estado enfrenta no mundo contemporâneo" (Trajetória recente da gestão pública brasileira: um balanço crítico e a renovação da agenda de reformas, p.74).
} 
Não se pode deixar de mencionar, nesse sentido, a noção de tributação participativa, na medida em que se o cidadão passa a participar de todas as esferas reguladas e regulamentadas pelo Estado, a tributação igualmente deverá se adaptar à nova tendência.

Heidelberg trata do direito privado de instituições públicas, o que descreve como a aplicação de lei relativa a questões de direito privado em questões tradicionalmente de direito público. ${ }^{39}$

Diante do novo modelo e das novas funções atribuídas ao Estado, surge necessidade de definição e de implementação de um novo modelo de governança, $^{40}$ ou seja, enquanto gestor da sociedade, o Estado deverá atender às novas demandas e relações muitas vezes como gestor, não mais como provedor e regulador.

Canotilho ${ }^{41}$ define good governance, ressaltando quatro aspectos: (i) a expressão significa (numa concepção normativa) a condução responsável pelos assuntos do Estado; (ii) ela acentua a interdependência internacional dos Estados, (iii) recupera dimensões do new public management como mecanismo de articulação de parcerias público-privadas e (iv) vincula-se a governabilidade, accountability ${ }^{42}$ e legitimação.

Abrucio, ${ }^{43}$ a seu turno, traz quatro eixos centrais para a modernização do Estado: $(i)$ profissionalização da burocracia (redução de cargos em comissão, profissionalização do alto escalão governamental, redefinição e fortalecimento das carreiras de Estado, aumento do investimento na capacitação de servidores e regulamentação do direito de greve; (ii)

39 No original: "application of private law categories to some classical domains of public law". In Transnational governance without a public law?, p. 329.

40 Para Gustavo Justino de Oliveira, governança pública seria "um modelo alternativo a estruturas governamentais hierarquizadas, implicando que os governos sejam muito mais eficazes em um marco de economia globalizada, não somente atuando com capacidade máxima de gestão, mas também garantindo e respeitando as normas e valores de uma sociedade democrática” (In Governança pública).

A governança envolve, para Bresser-Pereira, um processo "mais amplo, na medida em que transmite a idéia de que as organizações públicas não estatais ou as organizações da sociedade civil, empresas comerciais, cidadãos individuais e organizações internacionais também participam do processo de tomada de decisões, embora o governo continue sendo o ator central" (O modelo estrutural de governança pública, p. 9).

${ }^{41}$ José Joaquim Gomes Canotilho, in Brancosos e Interconstitucionalidade, p. 325-334.

42 Para definição e possíveis alcances do termo accountability, ver Scott Mainwaring, Introduction: democratic accountability in Latin America. Ressalta-se a necessária vinculação a baixos custos de transação (p. 4) e a dificuldade de conciliar a accountability à políticas governamentais efetivas e eficientes (p. 5).

${ }^{43}$ Fernando Luiz Abrucio. Trajetória recente da gestão pública brasileira: um balanço crítico e a renovação da agenda de reformas. p. 67-79. 
eficiência (mudança da lógica do orçamento, governo eletrônico); (iii) efetividade (gestão por resultados, entrosamento entre níveis de governo para se atingir a efetividade das políticas públicas e fortalecimento da regulação dos serviços públicos; e (iv) accountability (aumentar a transparência e responsabilização do poder público).

Como se vê, nos mais diversos aspectos o Estado sofreu mudanças que demandam pela caracterização de um novo regime, na medida em que as atuais relações e direitos não mais se encontravam resguardados pelo modelo ideal inerente ao Estado do Bem-Estar social.

Dentre as mudanças, é perceptível a nova natureza das relações em que o Estado se envolve, bem como as diversas espécies de conflitos que poderão emergir pois o Estado passa a atuar economicamente e também a contratar.

No atual cenário, as próprias características estatais deixam de ser voltadas aos seus interesses internos e passam a ser cada vez mais destinadas ao seu bom relacionamento com os administrados e também às novas relações internas da própria administração e entre as diversas esferas administrativas (nacionais e transnacionais).

O que se percebe, enfim, é a crise nos meios tradicionais para solução de controvérsias entre a administração e os administrados e também no seio da própria administração pública. ${ }^{44}$

Não atende aos anseios sociais e também econômicos que se aguarde por anos a fio por uma decisão judicial que, muitas vezes, sequer reflete o conhecimento técnico específico para tratar de determinada relação. Não se pode, outrossim, exigir que os magistrados se capacitem para atender à demanda das atuais e complexas relações inerentes à informatização e à diversidade de novas relações.

\footnotetext{
44 José Eduardo de Faria trata da crise dos mecanismos de solução de conflitos como sendo um "progressivo esgotamento tanto da operacionalidade quanto da eficácia dos mecanismos jurídicos convencionais dos Estados - especialmente dos instrumentos legais de regulação e controle econômica e financeira, que não acompanham a velocidade com que as atividades econômicas se globalizam, nas duas ou três últimas décadas do século 20, o mundo se globalizou”" (O Estado depois da crise, p. 35).
} 
É justamente nesse contexto que a arbitragem pode se mostrar uma solução adequada a determinadas controvérsias, pois (i) a especialidade dos árbitros na matéria em debate pode ser atrativa à sua decisão quanto ao destino da controvérsia e, ainda, (ii) a agilidade do julgamento de procedimentos arbitrais permite uma célere decisão, o que pode ser decisivo ao caso concreto.

De outro lado, a transação, na qualidade de método autocompositivo de solução de controvérsias, adéqua-se a atual demanda da sociedade por uma administração pública mais transparente e participativa.

Antes de se adentrar às características do crédito tributário per si, cumpre avaliar se a noção tradicional de supremacia do interesse público, que deságua na indisponibilidade desse interesse, permanece inalterada e, ainda, se tem condições de impedir que a administração pública adote meios alternativos para solucionar as controvérsias nas quais se vê envolvida.

\subsection{Releitura acerca da concepção de indisponibilidade do interesse público}

O modelo decadente de Estado acima descrito era representado pela inequívoca superioridade hierárquica do interesse tido por público em detrimento aos interesses particulares. É justamente nesse contexto que as novas relações enfrentadas pelo Estado e sua posição perante os particulares clamam pela releitura desse padrão, de forma que os interesses envolvidos sejam satisfatoriamente medidos e tratados.

A tradicional dicotomia entre público e privado, como visto, restou prejudicada, dentre outros fatores, em decorrência da participação e atuação do Estado em relações de natureza privada e, de outro lado, entes privados passam a atuar em esferas que, antes, eram exclusivamente cuidadas pelo poder público. ${ }^{45}$

${ }^{45}$ Pedro Gonçalves (Entidades privadas com poderes públicos, p. 270-275) trata da superação do modelo clássico que distinguia direito público administrativo de direito privado, na medida em que o direito administrativo passa a ser regulador de relações de poder, ressaltando também o declínio da administração de autoridade, na medida em que diversificaram-se as formas de agir da administração pública. 
Quanto à definição do interesse público, pode-se afirmar tratar-se do interesse da maioria, em detrimento do interesse do próprio Estado. ${ }^{46}$ Celso Antonio Bandeira de Mello $^{47}$ conclui sua teoria acerca da definição do interesse público afirmando que "o interesse público deve ser conceituado como o interesse resultante do conjunto dos interesses que os indivíduos pessoalmente têm quando considerados em sua qualidade de membros da Sociedade e pelo simples fato de o serem”. Salienta também o Professor que “interesse público é o interesse do todo, do próprio corpo social, para precatar-se contra o erro de atribuir-lhe o status de algo que existe por si mesmo, dotado de consistência autônoma, ou seja, como realidade independente e estranha a qualquer interesse das partes. $O$ indispensável, em suma, é prevenir-se contra o erro de, consciente ou inconscientemente, promover uma separação absoluta entre ambos, ao invés de acentuar, como se deveria, que o interesse público, ou seja, o interesse de todo, é "função" qualificada dos interesses das partes, um aspecto, uma forma específica, de sua manifestação".

Maria Sylvia Zanella Di Pietro ${ }^{48}$ destaca que são diversas as possíveis concepções de interesse público: pode se falar na ideia mais ampla a significar bem comum, "que constitui a própria finalidade do Estado"; sinônimo de interesse coletivo, difuso, geral; ou ainda "interesse público ainda mais delimitado quando o consideramos em face de um instituto determinado, por exemplo, quando falamos que a Administração pode alterar ou rescindir unilateralmente um contrato para atender a um interesse público".

46 A doutrina tradicionalmente distingue o interesse público primário do secundário (ver Celso Antonio Bandeira de Mello, Curso de Direito Administrativo, p. 76. No entanto, a distinção não traz aparente relevância ao presente estudo, pois o que importa à análise é a abrangência do conceito, e não as possíveis classificações doutrinárias que lhe conferem.

${ }^{47}$ Curso de Direito Administrativo, p.69-71. Vale destacar quanto à conceituação do interesse público, ainda, o ensinamento de que "existe, de um lado, o interesse individual, particular, atinente às conveniências de cada um no que concerne aos assuntos de sua vida particular - interesse, este, que é o da pessoa ou grupo de pessoas singularmente consideradas - ,e que, de par com isto, existe também o interesse igualmente pessoal destas mesmas pessoas ou grupos, mas que comparecem enquanto partícipes de uma coletividade maior na qual estão inseridos, tal como nela estiveram os que os precederam e nela estarão os que virão a sucedê-los nas gerações futuras.

Pois bem, é este o último interesse o que nomeamos de interesse do todo ou interesse público. Não é, portanto, de forma alguma, um interesse constituído autonomamente, dissociado do interesse das partes e, pois, passível de ser tomado como categoria jurídica, que possa ser erigida irrelatamente aos interesses individuais, pois, em fim de contas, ele nada mais é que uma faceta dos interesses dos indivíduos: aquela que se manifesta enquanto estes - inevitavelmente membros de um corpo social - comparecem em tal qualidade. Então, dito interesse, o público - e esta já é uma primeira conclusão -, só se justifica na medida em que se constitui em veículo de realização dos interesses das partes que o integram no presente e das que o integrarão no futuro. Logo, é destes que, em última instância, promanam os interesses chamados públicos."

48 Discricionariedade administrativa e controle judicial da administração, in Processo Civil $e$ interesse público. O processo como instrumento de defesa social, p. 14. 
Héctor Jorge Escola ${ }^{49}$ esclarece que o interesse do Estado não equivale ao interesse público, definindo este último como aquele que resulta do conjunto de interesses individuais compartilhados e coincidentes de um grupo majoritário de indivíduos, que diz respeito a toda uma comunidade como consequência dessa maioria, cuja origem se encontra no querer axiológico de todos os indivíduos, surgindo, enfim, um conteúdo concreto e determinado, atual, eventual ou potencial, pessoal e direito.

Rodolfo de Camargo Mancuso, ${ }^{50}$ ao tratar da possibilidade de o poder público solucionar suas controvérsias por conciliação, é conclusivo ao esclarecer que "não se deve, todavia, ceder ao argumento de que, por conta de os conceitos vagos ou indeterminados criarem zonas cinzentas no ordenamento positivo, ficaria o intérprete desonerado de tentar imprimir concreção conceitual a tais expressões, inclusive para viabilizar as decisões que tenham que ser prolatadas nos casos concretos em que tais expressões têm incidência.

Assim sendo, o Estado, em determinadas situações, terá interesse envolvido distinto daquele interesse que diz respeito à coletividade que por vezes representa. Ao Estado não basta, desse modo, ser voltado à satisfação dos seus anseios institucionais e nas diversas esferas em que atua, o bem maior será o melhor atendimento ao interesse da coletividade.

Gustavo Justino de Oliveira, ${ }^{51}$ analisando a nova administração pública, conclui que o processo determinação do interesse público passa a ser desenvolvido a partir de uma perspectiva consensual e dialógica, a qual contrasta com a dominante perspectiva imperativa e monológica, avessa à utilização de mecanismos comunicacionais internos e externos à organização administrativa.

\footnotetext{
${ }^{49}$ El interés público: como fundamento del derecho administrativo. P. 240. Tradução livre.

${ }^{50} \mathrm{O}$ plano piloto de conciliação em segundo grau de jurisdição, p. 873.

${ }^{51}$ Direito administrativo democrático, p. 211-221.
} 
Nesse sentido, oportuna a análise de Pedro Machete ${ }^{52}$ acerca da nova forma de atuação da administração pública em decorrência da complexificação e da intensificação das relações entre o Estado e a sociedade, trazendo as noções de administração cooperante e administração concertada. A partir dessa análise, levando em conta a posição especial do Estado perante a sociedade, conclui o autor que a superioridade jurídica do Estado deixou de se verificar: o Estado e todas as suas manifestações não podem mais ser concebidos como superiores juridicamente, ou mais valiosos do que os indivíduos.

Enfim, a geral e irrestrita supremacia do interesse do Estado sobre os interesses dos particulares deixa de ser razoável e desejada, o que remete a uma releitura da própria noção tradicional de indisponibilidade do interesse público. ${ }^{53}$

É certo que há situações que, quer pela Constituição Federal, quer pela lei, os bens públicos serão indisponíveis e somente poderão ser renunciados pela administração pública mediante autorização legal.

Entretanto, como bem observa Eduardo Talamini, ${ }^{54}$ sem prejuízo da existência de bens públicos indisponíveis, há ocasiões nas quais valores constitucionais justificam que, mediante lei, o Estado possa renunciar a determinadas ocorrências ou derivações do bem indisponível.

De outro lado, há situações nas quais o Estado não necessitará de lei específica para renunciar a determinado bem ou direito não gravado como indisponível, na medida em que os valores insertos na Constituição Federal e os objetivos da administração pública justificarão a atuação administrativa. ${ }^{55}$

\footnotetext{
${ }^{52}$ Estado de direito democrático e administração paritária, p. 46-55.

${ }^{53}$ Em sentido contrário, vale transcrever o entendimento de Celso Antonio Bandeira de Mello (Curso de direito administrativo, p. 79), para quem "o princípio da supremacia do interesse público sobre o interesse privado é princípio geral de Direito inerente a qualquer sociedade. É a própria condição de sua existência. Assim, não se radica em dispositivo específico algum da Constituição, ainda que inúmeros aludam ou impliquem manifestações concretas dele, como, por exemplo, os princípios da função social da propriedade, da defesa do consumidor ou do meio ambiente (art. 170, III, V e VI), ou tantos outros. Afinal, o princípio em causa é um pressuposto lógico do convívio social".

${ }_{54} \mathrm{~A}$ (in)disponibilidade do interesse público: consequências processuais, p. 60.

55 Importante ressaltar, nesse tocante, a relevância da motivação do ato administrativo. Ao renunciar a determinado bem, é essencial que o agente público não somente verifique se a lei ou mesmo a Constituição Federal conferem indisponibilidade ao objeto, mas também motivar sua decisão de forma que a renúncia não seja comprovadamente representativa do interesse e em linha com os princípios que norteiam a administração pública.
} 
Hugo de Brito Machado ${ }^{56}$ justifica a inviabilidade de solução mediante arbitragem de controvérsias tributárias justamente em razão de o direito da Fazenda de arrecadar $o$ tributo ser um direito indisponível.

Gustavo Binenbojm ${ }^{57}$ analisa a manutenção da supremacia do interesse público sobre o privado no modelo vigente, sempre alinhado à função e alcance do direito administrativo. Em sua análise, avalia a possibilidade de o interesse público possuir uma predisposta prevalência sobre os interesses dos particulares, ${ }^{58}$ trazendo a falta de respaldo constitucional à prevalência do interesse público, bem como demonstra, também por exemplos práticos, a necessidade de ponderação dos interesses envolvidos em determinada análise.

Em resposta ao artigo de Gustavo Binenbojm, a Prof. Maria Sylvia Zanella Di Pietro $^{59}$ refaz sua análise da origem da supremacia do interesse público, ressaltando seu posicionamento no sentido de que o Direito Administrativo seria bipolar (eis que trataria da liberdade do indivíduo e autoridade da Administração, restrições e prerrogativas) e, muito embora tenham havido alterações nas concepções no momento atual, não deixou de ser uma característica da ciência estudada. ${ }^{60}$

Di Pietro ressalta que o interesse público estaria presente nas seguintes searas: serviço público, fomento, intervenção, polícia administrativa e regulação (no tocante a este último, ressalta que somente estaria compreendido na relação para aqueles que consideram a modalidade como função administrativa).

${ }^{56}$ Transação e arbitragem no âmbito tributário, p. 130.

${ }^{57}$ Temas de direito administrativo e constitucional, p. 61-94.

${ }^{58}$ Para o autor, "o ponto mais evidente aqui passível de crítica é o de uma circularidade no raciocínio. Com efeito, na Constituição são encontrados os fundamentos para a restrição de direitos individuais em prol de interesses da coletividade. Ora, se é a Constituição que, explícita ou implicitamente, estabelece quando e em que medida direitos individuais podem ser restringidos, (I) o fundamento da restrição é a norma constitucional específica, e não o dito princípio e (II) a medida da restrição, conforme permitida pela Constituição, é dada por uma norma de proporção e preservação recíproca dos interesses em conflito, e não de prevalência a priori do coletivo sobre o individual." (Temas de direito administrativo e constitucional, p. 75).

${ }^{59}$ O princípio da supremacia do interesse público: sobrevivência diante dos ideais do neoliberalismo, p. 85102.

${ }^{60}$ Em sua obra Direito Administrativo, a Prof. Maria Sylvia Zanella Di Pietro traz a "reação contra o princípio da indisponibilidade do interesse público" como atual tendência do direito administrativo, afirmando que o interesse público deverá se sobrepor sobre o particular, sempre em atenção ao princípio da razoabilidade (p. 36-38). 
É nesse sentido que Di Pietro afirma que existem interesses públicos que merecem proteção do Estado, ainda que em detrimento de interesses individuais. É do ordenamento jurídico que se extrai a idéia de interesse público e quais os interesses públicos a proteger. Interesses públicos, correspondentes ou não à soma de interesses individuais, sempre existiram e sempre vão existir, a menos que se queira negar o papel do Estado como garantidor do bem comum. ${ }^{61}$

Como se vê, a questão é controversa, havendo ainda muito debate na doutrina especializada. No entanto, quer em razão da nova ordem e das novas funções desenvolvidas pelo Estado, quer diante da nova resposta que a sociedade espera das ações estatais, se espera que o Estado não deixe de adotar determinada solução em razão da vazia alegação de que o interesse público seria indisponível.

O que é indisponível é o dever do Estado de agir no interesse da sociedade e de acordo com os princípios constitucionais vigentes. Nesse exato sentido vale mencionar que se trata, de fato, de um novo paradigma,o qual para Lauro da Gama e Souza Jr. "promove como instrumental técnico o dever de proporcionalidade e a análise do interesse público em cada caso concreto, levando-se em consideração os princípios constitucionais aplicáveis, à luz de seu eixo valorativo central: o princípio da dignidade da pessoa humana". 62

Para tanto, poderá ser necessário que se disponha de determinado bem, homenageando uma solução mais adequada e menos gravosa à sociedade para determinado conflito, com o que será atendida a eficiência elevada a princípio constitucional.

Uma análise à luz da possibilidade de as controvérsias em que o setor público se envolve serem solucionados por arbitragem foi feita por Carlos Alberto de Salles ${ }^{63} \mathrm{em}$ tese de livre docência na qual o autor analisa a viabilidade de adoção de solução arbitral para

${ }^{61}$ O princípio da supremacia do interesse público: sobrevivência diante dos ideais do neoliberalismo, p. 99.

${ }^{62}$ In Sinal verde para a arbitragem em parcerias público-privadas (a construção de um novo paradigma para os contratos entre o Estado e o investidor privado), p. 16.

${ }^{63}$ Arbitragem em contratos administrativos, p. 292-295. 
controvérsias contratuais da administração pública. A análise parte da indisponibilidade relativa à relação entre bens e sujeitos e outra atinente aos bens.

Quanto a estes últimos, há bens efetivamente indisponíveis, dos quais, por força de determinação legal ou mesmo constitucional o Estado não poderá dispor, a não ser que exista expressa autorização legislativa.

De outro lado, em se tratando da indisponibilidade relativa à relação entre bens e sujeitos, deve ser avaliada a titularidade originária do bem jurídico ${ }^{64} \mathrm{e}$, nesse tocante, os titulares podem ser um sujeito específico ou mesmo a coletividade.

Desse modo, tratamento adequado ao conflito deverá ser aquele que verifique qual a solução que melhor atenderá ao interesse coletivo envolvido, seja em se tratando de conflito coletivo (envolvendo o meio ambiente, por exemplo), seja conflito envolvendo determinado indivíduo (como o decorrente de contrato administrativo ou até mesmo o tributário).

Destarte, atualmente a mera alegação de que o Estado não poderia utilizar meios alternativos ao judicial para buscar solução das controvérsias nas quais se envolve em razão da inviabilidade de dispor de seus bens e direitos em razão da prevalência do interesse público sobre o particular não parece merecer guarida, pois há inúmeros aspectos a serem avaliados para que se defina qual o tratamento adequado às controvérsias envolvendo o Poder Público.

Em verdade, o Estado deverá avaliar qual o interesse efetivamente envolvido na controvérsia e decidir pela solução que melhor atenda ao bem estar da coletividade. Desse modo, uma solução de determinada controvérsia não deverá ser avaliada mediante análise exclusiva da relação em jogo, mas sim dos objetivos institucionais do Estado e da demanda social.

${ }^{64}$ Carlos Alberto de Salles, Arbitragem em contratos administrativos, p. 293-294. 
Assim sendo, salvo se tratar de bem indisponível, o interesse exclusivamente Estatal deixa de ter privilégios frente aos interesses dos particulares e da coletividade.

Feita essa análise acerca do interesse público geral, passa-se no item seguinte à avaliação da abrangência e dimensão da indisponibilidade do crédito tributário para, após, tratar-se da arbitrabilidade e transigibilidade do crédito tributário.

\subsection{Natureza da controvérsia tributária}

As controvérsias tributárias decorrem de relação entre fisco e contribuinte (sujeitos ativo e passivo da relação jurídico tributária, respectivamente) e versam sobre o crédito tributário. O crédito tributário, a seu turno, é meio de fornecimento para o Estado de receitas necessárias para cumprimento das necessidades públicas básicas. ${ }^{65}$

Geraldo Ataliba" ${ }^{66}$ esclarece que "estabelece-se conflito entre o fisco (órgão fazendário do Estado) e o e contribuinte, sempre que aquele manifesta uma pretensão resistida por este. Ao exigir o fisco um tributo, uma multa ou um dever acessório, pode o sujeito passivo dessas exigências a elas resistir, por entende-las infundadas ou excessivas. A divergência - ensejadora do litígio, contenda, dissídio - sempre se fundará em diversa interpretação da norma jurídica aplicável ou na diferente apreciação ou 'qualificação jurídica' dos fatos relevantes para os efeitos de aplicação da norma."

A norma tributária prevê uma situação hipotética a qual, verificada no mundo real, gera uma obrigação ao contribuinte (de honrar com o pagamento do crédito tributário) e um direito do sujeito ativo (de arrecadar o tributo). Nos dizeres de Geraldo Ataliba, tãologo verificada a hipótese hipoteticamente prevista na norma tributária, o dinheiro do contribuinte passa a pertencer ao fisco: "como a norma confere a um fato o efeito jurídico

\footnotetext{
${ }^{65}$ Nesse sentido, vide concepção do direito tributário apresentada por Tathiane dos Santos Piscitelli, Argumentando pelas consequências no direito tributário. A autora traz na própria concepção que o provimento do Estado se dará a partir da justiça fiscal, absolutamente em linha com o presente estudo, o qual busca métodos adicionais aos existentes para solução de controvérsias tributárias buscando a tributação mais justa - ou seja, visando sobretudo à justiça fiscal.

${ }^{66}$ Recurso em matéria tributária, p. 123.
} 
de atribuir a titularidade de uma soma de dinheiro ao poder público, assim que acontecido este fato o sujeito passivo (contribuinte) perde a titularidade desse dinheiro" ${ }^{67}$

Uma vez ocorrido o fato hipoteticamente delineado na norma de incidência, o sujeito ativo tem direito subjetivo de exigir a prestação do sujeito passivo que, a seu turno, tem dever jurídico de cumpri-la. ${ }^{68}$ Cumprida a obrigação, extingue-se a relação jurídica e, em contrapartida, caso não satisfeita, surge a controvérsia tributária.

Nesse passo, pode-se definir o crédito tributário a partir dos ensinamentos de Paulo de Barros Carvalho ${ }^{69}$ como sendo "o direito subjetivo de que é portador o sujeito ativo de uma obrigação tributária e que lhe permite exigir o objeto prestacional, representado por uma importância em dinheiro".

Surge, assim, o tributo, cuja definição vem descrita no artigo $3^{\circ}$ do Código Tributário Nacional: ${ }^{70}$

Tributo é toda prestação pecuniária compulsória, em moeda ou em cujo valor nela se possa exprimir, que não constitua sanção de ato ilícito, instituída em lei e cobrada mediante atividade administrativa plenamente vinculada.

${ }^{67}$ Hipótese de Incidência Tributária, p. 32.

${ }^{68}$ Nesse sentido, Paulo de Barros Carvalho, Direito Tributário, linguagem e método, p. 419.

${ }^{69}$ Direito Tributário, linguagem e método, p. 421.

${ }^{70}$ Geraldo Ataliba, Hipótese de Incidência Tributária, pp. 35-36, destrincha a definição do artigo $3^{\circ}$ do CTN definindo OBRIGAÇÃ̃ como sendo o "vínculo jurídico transitório, de conteúdo econômico, que atribui ao sujeito ativo o direito de exigir do passivo determinado comportamento e que a este põe na contingência de praticá-lo, em benefício do sujeito ativo"; PECUNIÁRIA na medida em que "há necessidade de que seu objeto seja: o comportamento do sujeito passivo consistente em levar dinheiro ao sujeito ativo"; "EX LEGE" pois "a obrigação tributária nasce da vontade da lei, mediante a ocorrência de um fato (fato imponível) nela descrito. Não nasce, como as obrigações voluntárias (ex voluntate), da vontade das partes. Esta é irrelevante para determinar o nascimento deste vínculo obrigacional"; QUE NÃO SE CONSTITUI EM SANÇÃO DE ATO ILÍCIO já que "o dever de levar dinheiro aos cofres (tesouro = fisco) do sujeito ativo decorre do fato imponível. Este, por definição, é fato jurídico constitucionalmente qualificado e legalmente definido, com conteúdo econômico, por imperativo da isonomia (art. $5^{\circ}$, caput e inciso I da CF), não qualificado como ilícito. Dos fatos ilícitos nascem multas e outras consequências punitivas, que não configuram tributo, por isso não integrando seu conceito, nem submetendo-se a seu regime jurídico"; CUJO SUJEITO ATIVO É EM PRINCÍPIO UMA PESSOA PÚBLICA como sendo "regra geral ou o sujeito ativo é uma pessoa pública política ou 'meramente administrativa", destacando ainda que "a quem a lei atribua capacidade de ser sujeito ativo de tributos a pessoas privadas - o que, embora excepcional, não é impossível - desde que estas tenham finalidades de interesse público. Configura-se, assim, a parafiscalidade"; e, finalmente, CUJO SUJEITO PASSIVO É UMA PESSOA POSTA NESTA SITUAÇÃO PELA LEI pois “ $a$ lei designa o sujeito passivo. A lei que qualifica o sujeito passivo explícito, o 'destinatário constitucional tributário"”. 
A partir da definição acima de tributo, dois aspectos são particularmente interessantes ao presente estudo.

O primeiro deles reside no fato de o tributo ser, necessariamente, uma prestação pecuniária. ${ }^{71}$ Para fins desta análise tal característica é de extrema relevância na medida em que em se tratando de moeda, consequentemente poderemos considerar o tributo como algo disponível. ${ }^{72}$

Com efeito, a partir do momento em que se configura o fato gerador do tributo, ${ }^{73} \mathrm{o}$ contribuinte deixa de ter direito sobre o valor em questão na medida em que nesse momento sua obrigação de pagar o tributo se torna real, concreta e exigível. ${ }^{74}$

Em razão do caráter pecuniário do tributo, é possível concluir que qualquer controvérsia acerca da sua natureza será, necessariamente, conversível. Ou seja, na solução das controvérsias tributárias será sempre estabelecida uma obrigação de dar (moeda), surgindo um direito de receber. ${ }^{75}$

Outro aspecto que merece especial atenção considerando o objeto da presente análise é o fato de sua cobrança se dar por atividade administrativa plenamente vinculada. ${ }^{76}$ Tal aspecto será tratado especialmente quando da análise da viabilidade de o

\footnotetext{
${ }^{71}$ Regina Helena Costa, in Código Tributário Nacional, p. 21, ressalta a redundância do texto legal, que além de mencionar prestação pecuniária, também prescreve se tratar de prestação que "em moeda ou em cujo valor nela se possa exprimir", mas atenta ao fato de tal aspecto ser essencial para compreensão da natureza do tributo.

72 Essa questão será tratada com mais ênfase quando da análise da arbitrabilidade e da transigibilidade do crédito tributário, II.1 e III.1 infra.

${ }^{73} \mathrm{Na}$ doutrina latino americana, Paulo de Barros Carvalho merece créditos pela teoria desenvolvida para explicitar o momento da subsunção do fato à norma jurídico tributária.

O Professor, acerca do núcleo lógico-estrutural da proposição normativa tributária, conclui que "efetuadas as devidas abstrações lógicas, identificaremos, no descritor da norma, um critério material (comportamento de uma pessoa, representado por verbo pessoal e de predicação incompleta, seguido pelo complemento), condicionado no tempo (critério temporal) e no espaço (critério espacial). Já na consequência, observaremos um critério pessoal (sujeito ativo e sujeito passivo) e um critério quantitativo (base de cálculo e alíquota)" (Direito Tributário - Linguagem e Método, p. 533).

${ }^{74}$ Nesse sentido, Geraldo Ataliba, in Hipótese de Incidência Tributária, afirma que "como norma confere a um fato o efeito jurídico de atribuir a titularidade de uma soma de dinheiro ao poder público, assim que acontecido este fato o sujeito passivo (contribuinte) perde a titularidade desse dinheiro." (p. 32)

${ }^{75}$ Importante ressaltar que nem sempre a controvérsia será resolvida no sentido de obrigar o contribuinte a pagar dinheiro ao Fisco. Há situações de indébito tributário nas quais a controvérsia é resolvida determinando que o Fisco, sujeito ativo da relação jurídico-tributária, entregue moeda ao contribuinte, sujeito passivo da relação.

${ }^{76}$ Acerca da atividade do lançamento tributário, vide definição no artigo 142 do CTN.
} 
poder público submeter as controvérsias em que se envolve a solução diversa daquela propiciada pela jurisdição estatal.

A letra do Código Tributário Nacional (“CTN") determina que não pode ser conferida margem de discricionariedade ao administrador público que atua na cobrança e arrecadação de tributos e, desse modo, sugere-se que quaisquer métodos de solução de controvérsias tributárias não poderão confiar ao agente público margem de discricionariedade no tocante à cobrança e arrecadação do tributo, sendo necessário que a lei traga em detalhes quais os métodos, abrangência e margem da atuação no momento da solução das controvérsias. ${ }^{77}$

Pois bem, acima há apontamentos sobre os sujeitos da relação jurídico-tributária e também sobre o seu objeto, qual seja, o crédito tributário. Chegado, finalmente, o momento de tratar da controvérsia tributária.

Caso o sujeito passivo deixe de honrar com a obrigação tributária, o sujeito ativo, e, decorrência da competência tributária outorgada pela Constituição Federal $^{78}$ e no exercício do seu direito de receber o crédito tributário, tem o poder-dever de proceder ao lançamento $^{79}$, passo anterior e necessário exigência do crédito em questão.

Nesse momento surgirá a controvérsia tributária, na medida em que o direito do sujeito ativo restou ferido por falta de cumprimento, por parte do sujeito passivo, da obrigação surgida a partir da subsunção do fato à norma abstrata tributária.

Quanto ao surgimento da obrigação tributária, vale trazer os ensinamentos de James Marins: ${ }^{80}$

${ }^{77}$ Nesse tocante, vide maiores reflexões infra, II.1.6; II.2.4; III.2.1.

78 A Constituição Federal outorga competência tributária nos seus artigos 145, 147, 148, 149, 149-A, 150, $153,154,155$ e 156.

${ }^{79}$ Quanto ao lançamento como ato prévio e necessário à cobrança do crédito tributário, importante salientar que o Superior Tribunal de Justiça pacificou o entendimento de que em se tratando de tributo declarado pelo sujeito passivo e não pago, não é necessário haver lançamento formal pela autoridade administrativa, sendo viável a imediata cobrança do débito (Súmula 436). Resta, no entanto, refletir se esse entendimento está em linha com o disposto no artigo 142 do CTN.

${ }^{80}$ Direito Processual Tributário Brasileiro, p. 98. 
a existência da obrigação tributária decorre da ocorrência de evento no mundo dos fenômenos (fato jurídico tributário) cujo conceito se encaixe na descrição hipotética, geral e abstrata, presente na norma jurídica tributária (hipótese de incidência tributária) e que é o antecedente lógico da consequência tributária correspondente à obrigação de pagar tributo.

Por corresponder ao momento estático da relação jurídica tributária, a mera existência da obrigação, contudo, não equivale ao ingresso do tributo e demanda a criação de mecanismos administrativos indispensáveis a propiciar arrecadação tributária, disciplinando o modo como deve se comportar o contribuinte para cumprir com sua obrigação perante o Estado e o modo como a Administração tributária deverá proceder com o escopo de evitar a inércia tributária e, em havendo resistência do contribuinte à pretensão fiscal, os mecanismos aptos para a solução de lide.

Atuação da obrigação tributária. Existe a relação jurídica (obrigação tributária) sua atuação irá depender de procedimentos de fiscalização, formalização e cobrança, praticados pela Administração tributária ou mesmo atos de formalização e recolhimento praticados diretamente pelo próprio contribuinte sem intervenção exatorial.

Essa atividade de mobilização, que tem por finalidade a realização do ato de lançamento tributário, é regida pelo denominado Direito Tributário formal que corresponde ao momento dinâmico da relação jurídica tributária.

A cobrança do crédito tributário poderá ser levada a termo pelo sujeito ativo e, em homenagem aos princípios do contraditório, da ampla defesa e do devido processo legal, o sujeito passivo terá meios e instrumentos para questionar a cobrança na eventualidade de discordar do lançamento.

A controvérsia tributária poderá, no entanto, existir previamente a falta de adimplemento pelo sujeito passivo quanto ao objeto da obrigação tributária. Isso porque no momento de formação da obrigação tributária poderá surgir campo para desentendimentos entre fisco e contribuinte que, a despeito de interferirem diretamente na formação do tributo, são prévios a sua existência.

Outrossim, há conflitos travados entre fisco e contribuinte que não envolvem diretamente o crédito tributário mas deste decorrem. Exemplo clássico são as controvérsias relativas a emissão de certidões de regularidade fiscal.

A controvérsia poderá, desse modo, tratar de quaisquer dos elementos da relação, pois o sujeito passivo poderá questionar o exercício da competência tributária, ${ }^{81}$ a validade dos elementos da relação e os aspectos da norma tributária. ${ }^{82}$ Poderá, também, surgir

81 Artigos 145 e seguintes da Constituição Federal. Sobre competência tributária, vide Paulo de Barros Carvalho, Direito Tributário, Linguagem e Método, pp. 227 e seguintes; Tathiane dos Santos Piscitelli, Argumentando pelas consequências no direito tributário, p. 232-234.

${ }^{82}$ Quanto aos aspectos da hipótese de incidência, ver Geraldo Ataliba, in Hipótese de incidência Tributária, que traz detalhes sobre os aspectos pessoal (p. 80 e seguintes), temporal (p. 94 e seguintes), espacial (p. 104105) e material (p. 106 e seguintes). 
previamente à constituição do crédito tributário ou tratar de aspecto extrínseco a sua essência.

Passa-se, enfim, à análise do direito processual posto ao contribuinte e ao fisco para solução das controvérsias tributárias. 


\section{CAPÍTULO 3 - DIREITO PROCESSUAL TRIBUTÁRIO POSITIVADO}

$\mathrm{Na}$ medida em que o objeto deste estudo corresponde a análise de aspecto processual relacionado a solução de controvérsias tributárias, é importante analisar o atual status das formas positivadas postas à disposição de fisco e contribuinte, sem deixar de inicialmente traçar os aspectos especiais do tipo de lide objeto deste estudo.

\subsection{A lide tributária}

Lide, tal como utilizada pelo Código de Processo Civil (“CPC”), significa causa ou demanda, ${ }^{83}$ e para parte da doutrina processualista estará sempre vinculada à existência de processo judicial.

No âmbito do direito tributário e partindo das premissas conceituais que fundamentam a presente análise, a lide não necessariamente estará vinculada à existência de processo judicial, pois há previsão de contencioso administrativo para solução das controvérsias tributárias. ${ }^{84}$

Em se tratando de controvérsia tributária, a partir do momento em que o contribuinte discordar da cobrança perpetrada pelo sujeito ativo, ${ }^{85}$ instaurar-se-á a lide, que poderá tratar não só da indevida cobrança, mas também visar à restituição daquilo que tenha sido indevidamente entregue ao sujeito ativo (na medida em que tenha sido entregue com lastro em cobrança lastreada em aspectos inadequados). ${ }^{86}$

\footnotetext{
${ }^{83}$ Nesse sentido, Cândido Rangel Dinamarco, Instituições de direito processual civil, vol. II, p. 107.

${ }^{84}$ Vide apontamentos sobre os meios de solução já existentes, I.3.2 infra.

${ }^{85}$ Cleide Previtalli Cais traz que "se o modelo insculpido não corresponder aos princípios constitucionais elou for contrário a texto de norma ordinária pertinente ao assunto, segue-se que está facultado ao sujeito passivo da obrigação tributária, ou seja, ao contribuinte, o acesso ao Estado julgador para impugnar a obrigação que lhe foi imposta pelo Estado administrador" (in O processo tributário, p. 145).

${ }^{86}$ James Marins define a lide tributária a partir da situação na qual fica "Vencida a estaticidade inerente ao fenômeno de incidência, isto é, superada a inércia tributária e estabelecida formalmente a pretensão do Estado sobre a esfera jurídica do contribuinte pode este discordar da existência jurídica do crédito tributário ou do quantum que lhe é exigido ou da penalidade imposta, estabelecendo-se o conflito entre o Estado e o cidadão que pode originar a lide tributária e inserir no âmbito da relação jurídica seu momento crítico", concluindo que "decorre da resistência formal do contribuinte (através de impugnações e recursos)
} 
Há de se ressaltar que o surgimento da lide tributária, diferentemente do que se verifica em outras áreas do direito, independe da vontade de ambos os sujeitos envolvidos. Isso porque o sujeito passivo pratica o ato que acaba por gerar o fato gerador do tributo não por pretender fazer surgir a obrigação tributária, mas porque tal ato lhe é interessante e necessário às atividades cotidianas.

Por exemplo, as pessoas trabalham para obter rendimentos necessários ao sustento pessoal e dos seus familiares. Em decorrência do rendimento recebido a partir do trabalho, as pessoas físicas passam a se sujeitar à incidência do Imposto sobre a Renda na medida em que haja produto do trabalho tributável. ${ }^{87}$

Não se concebe que alguém opte por exercer atividade remunerada tão somente em decorrência da intenção de se tornar contribuinte do Imposto sobre a Renda e pagá-lo ao fisco.

De outro lado, não parece razoável que o agente público tenha intenção pessoal de fiscalizar o contribuinte para retirar parcela do rendimento de seu trabalho para fins de arrecadação do Imposto sobre a Renda. Não há animus dos agentes imbuídos do poderdever de fiscalizar e arrecadar o imposto sobre a renda, diminuindo o rendimento decorrente do exercício de trabalho assalariado das pessoas. Na verdade, a lei manda que determinado percentual do produto do trabalho remunerado seja entregue ao fisco para fornecer meios de execução das atividades estatais.

Do mesmo modo se verifica com as pessoas jurídicas, na medida em que os atos que fazem surgir as obrigações tributárias são inerentes à prática da atividade negocial das empresas. Por exemplo, a empresa não importa determinada matéria prima com a intenção de tornar exigíveis os tributos incidentes no desembaraço aduaneiro; em verdade, por necessitar daquela matéria prima e encontrar no produto importado condição mais

à pretensão formal do Estado sobre sua esfera patrimonial (lançamento ou penalização) e será disciplinada pelo Direito Processual Tributário, em virtude de expressas injunções constitucionais" (Direito processual tributário brasileiro - administrativo e judicial).

${ }^{87}$ CTN, artigo 43, I. 
favorável, a empresa opta por adquiri-la fora do país e, para tanto, há encargos incidentes na importação.

Ou seja, ambos sujeito ativo e sujeito passivo se envolvem involuntariamente na controvérsia atinente ao crédito tributário sem intenção e passam a compor a relação jurídico tributária e suportar os ônus dela decorrentes.

Nos dizeres de James Marins,

"tal ordem de problemas é fruto da natureza indiscutivelmente peculiar da relação obrigacional tributária, cujo crédito nasce independente da vontade de seus sujeitos e não pode ser alterado, senão em virtude de lei (constitucionalmente válida), o que significa dizer que carece de fundamento de validade a lei que atribua genericamente à vontade individual - seja do sujeito ativo ou do sujeito passivo - o condão de extinguir ou mesmo modificar o conteúdo da relação obrigacional, especialmente quando está em jogo a incerteza sobre a constitucionalidade de norma jurídica tributária. Da mesma carência de fundamento de validade sofre a lei que condiciona o ingresso a programa de parcelamento à renúncia a direitos subjetivos públicos como a inafastabilidade da tutela jurisidicional ou o de semelhante jaez imprimem à adesão a sobra da abusividade que é incompatível com a ordem jurídica, quer no terreno do Direito Privado como no campo do Direito Público, mas em especial quando estão associados temas relativos a garantias individuais e especial segurança constitucional como é o caso da tributação. A praticidade e o utilitarismo de certas fórmulas aparentemente lógicas não podem se impor como fatores superiores a comprometer a ordem constitucional e tributária." 88

Pois bem. Tem-se que a lide tributária independe e não se vincula necessariamente a existência do processo judicial e, outrossim, que a controvérsia tributária, anterior e necessária a existência da própria lide, não surge em decorrência da vontade dos sujeitos envolvidos, mas lhe é imposta pelas normas tributárias que conferiram a determinado fato da vida real relevância para fins tributários.

Cumpre, nesse estágio, analisar brevemente quais os métodos disponíveis para solução das controvérsias tributárias.

${ }^{88}$ Direito Processual Tributário Brasileiro (Administrativo e Judicial), p. 316-317. 


\subsection{Notas sobre as formas de solução de controvérsias tributárias positivadas}

Há na legislação tributária em vigor previsão de meios judiciais e administrativos como hábeis à solução ${ }^{89}$ das controvérsias tributárias. Há, outrossim, meios preventivos postos à disposição das partes para solucionar dúvidas e direcionar os atos dos contribuintes.

Vale destacar, de início, que a breve análise ora é meramente informativa e desprovida de intenção de adentrar nas divergências doutrinárias relativas ao assunto. Entende-se, apenas, importante fazer breves referências à previsão legal já existente na medida em que o objeto deste estudo é tratar dos métodos distintos daqueles já postos.

\subsubsection{Métodos preventivos à constituição do crédito tributário}

Em se tratando de métodos preventivos de controvérsias tributárias, os artigos 46 a 58 do Decreto 70.235 tratam do processo administrativo de consulta, posto à disposição do contribuinte para, no âmbito da Secretaria da Receita Federal do Brasil, com a exceção de determinados Estados e Municípios que, embora minoria, possuem previsão legal no mesmo sentido, solucionar dúvidas que poderão indicar os meios de atuação para fins de afastar ou adequar determinada prática à tributação.

A apresentação da consulta resguarda o contribuinte de eventuais procedimentos fiscalizatórios em decorrência dos fatos consultados desde a data da apresentação da consulta e até trinta dias subsequentes à data da ciência da decisão proferida pela administração; ainda, a legislação prevê tanto a instauração de processo acerca da decisão proferida pela administração ${ }^{90}$ quanto à possibilidade de o contribuinte questionar o

\footnotetext{
${ }^{89}$ Cumpre destacar, na medida em que os diversos Estados, Distrito Federal e Municípios são dotados de competência tributária, que há ampla gama de formas e meios legalmente previstos para a solução das controvérsias tributárias respectivas.

Nesse sentido, vale mencionar nosso A transação na solução de controvérsias tributárias: uma análise das hipóteses legais, que cuidou de analisar as normas de transação em vigor para regular tal método de solução das controvérsias tributárias.

Para concentrar o objeto do presente estudo nas normas mais amplamente estudadas, aceitas e aplicadas, a análise aqui realizada incluirá o CTN, o Decreto 70.235, de 6 de março de 1972 e a Lei de Execuções Fiscais (LEF, Lei 6.830 de 22 de setembro de 1980).

${ }^{90} \mathrm{Cf}$. artigo 56 do Decreto 70.235 .
} 
entendimento manifestado mediante alegação divergência quando encontrar soluções conflitantes expedidas pelo próprio fisco. ${ }^{91}$

O procedimento de consulta é particularmente interessante na medida em que o sujeito passivo pode delinear sua atuação com relação a determinado fato a partir do conhecimento prévio do posicionamento do fisco e, dessa forma, evitar futuro litígio. Por exemplo, determinada pessoa jurídica está em vias de passar a comercializar determinado produto e tem dúvidas acerca da correta classificação fiscal aplicável. Por meio de consulta, o contribuinte poderá obter posicionamento do fisco antes mesmo de iniciar a comercialização do produto, evitando, assim, que seja conferida classificação divergente e consequente tributação do produto em desacordo com os critérios que o Fisco entende correto.

De outro lado, a resposta à consulta não vincula o físco a agir de determinado modo, permeando somente a relação no que diz respeito ao contribuinte que tenha recebido a solução e garantido ao contribuinte em questão o direito de permanecer amparado pelo posicionamento fiscal até que tenha ciência de ato formal informando sobre posicionamento contrário àquele da consulta. ${ }^{92}$

O instituto da denúncia espontânea ${ }^{93}$ afasta a multa de mora, homenageando a boafé, nos casos em que o contribuinte que não esteja sendo fiscalizado sobre determinado fato realize o pagamento em atraso de tributos, justamente em razão do caráter punitivo da penalidade, incluindo no pagamento tão-somente os juros de mora. ${ }^{94}$

Cumpre tratar também do procedimento ${ }^{95}$ de fiscalização, regido por normas legais ${ }^{96} \mathrm{e}$ infralegais e representa a atividade plenamente vinculada da administração pública. Há ritos específicos e formalidades, tais como as do artigo $7^{\circ}$ do Decreto 70.235 ,

\footnotetext{
${ }^{91}$ Cf. artigo 48, parágrafo 10 da Lei 9.430/96.

${ }^{92}$ Cf. artigo 48, parágrafo 12 da Lei 9.430.

${ }^{93}$ Previsto no artigo 138 do CTN.

${ }^{94}$ O Superior Tribunal de Justiça consolidou seu entendimento jurisprudencial no sentido de que o benefício da denúncia espontânea somente é concedido ao contribuinte que sequer declarou o tributo a ser pago, consoante texto da Súmula 360: "O benefício da denúncia espontânea não se aplica aos tributos sujeitos a lançamento por homologação regularmente declarados, mas pagos a destempo."

${ }^{95}$ Esse termo é utilizado pela própria lei e foi aqui repetido.

${ }^{96}$ Ressaltam-se os artigos 194 e seguintes do CTN, bem como artigos $2^{\circ}$ e seguintes do Decreto 70.235.
} 
que regulamenta a administração pública federal, que a despeito de intitular as providências por "procedimento fiscal”, traz ritual típico de processo.

Podemos, para fins do objeto do presente estudo, dividir a fiscalização meramente destinada ao pleno exercício do poder de polícia pelo Estado, ou seja, aquela destinada a aplicação das normas tributárias sem qualquer investigação ou mesmo participação do contribuinte.

No âmbito federal, cita-se o procedimento de conferência do despacho aduaneiro, destinado a conferir as características das mercadorias desembaraçadas pelo contribuinte e as informações constantes dos documentos de importação. Não há discricionariedade (no sentido de opção pela prática ou não do ato) do agente fiscal no momento da conferência: uma vez constatada divergência entre a carga e o material declarado, lavra-se o auto de infração e imposição de multa.

Outro exemplo seria a emissão de cobrança contra o contribuinte em decorrência da existência de pendências por divergências entre os valores de tributos e contribuições federais declarados e aqueles reconhecidos como recolhidos pelos sistemas da Receita Federal do Brasil: havendo divergências, o contribuinte é automaticamente intimado para realizar o pagamento e, sem qualquer instauração de contencioso, prossegue-se com o procedimento de cobrança, fulminando no ajuizamento de ação executiva fisscal.

Além dessa fiscalização realizada como exercício do Poder de Polícia, há também o procedimento investigativo exercido pelos agentes fiscais, em atividade que compreende inclusive a instauração de processo na medida em que o contribuinte é intimado para prestar informações, esclarecimentos e sua versão dos fatos investigados. 
Nesse momento, a despeito de a finalidade precípua consistir na lavratura do auto de infração, ${ }^{97}$ inaugura-se verdadeira etapa processual, na medida em que as partes envolvidas passam a, mediante exercício do contraditório, dialogar para solução de controvérsia.

A concepção mais tradicional de processo entende se tratar de "técnica imperativa de solução de conflitos", ressaltando que "falar em solução imperativa de conflitos corresponde a afirmar que o processo civil constitui monopólio estatal". ${ }^{98}$

A partir de uma concepção mais moderna, o termo processo não engloba apenas o judicial (cujo monopólio é efetivamente estatal), mas todo e qualquer conjunto normativo que regule conjunto sucessivo de atos destinados à consecução de determinada formalidade, com atendimento do contraditório.

Uma leitura do pensamento de Fazzalari, que, pioneiramente, destituiu a relação jurídica processual da concepção de processo, foi feita por Cintra, Grinover e Dinamarco, ${ }^{99}$ que concluem ser "lícito dizer, pois, que o processo é o procedimento realizado mediante o desenvolvimento da relação entre seus sujeitos, presente o contraditório". No entanto, concluem os autores que a concepção se restringe ao processo judicial. ${ }^{100}$

Carlos Alberto de Salles, em sua obra Arbitragem em contratos administrativos, trata do processo como sendo um conjunto de regras (procedimento) que visa a uma decisão e é dotado de contraditório. ${ }^{101}$ Confira-se:

\footnotetext{
${ }^{97}$ Cumpre salientar que há ampla divergência doutrinária sobre a qualificação jurídica do ato de lançamento e da lavratura do auto de infração propriamente ditos. Nesse sentido, veja James Marins, Direito Processual Tributário Brasileiro, p. 204 e ss, e também Estevão Horvath, Lançamento Tributário e "Autolançamento", p. 33 e ss..

${ }_{98}$ Cf. Dinamarco, Instituições de Direito Processual Civil, vol, I, p. 35 e 36.

${ }^{99}$ Teoria Geral do Processo, p. 285.

${ }^{100}$ Afirmam os autores que "Ao garantir a observância do contraditório a todos os 'litigantes em processo judicial ou administrativo e aos acusados em geral', está a Constituição (art. $5^{\circ}$, inc. LV) formulando a solene existência política de que a preparação de sentenças e demais provimentos estatais se faça mediante o desenvolvimento da relação jurídica processual" (Teria geral do processo, p. 285).

${ }^{101}$ Importante destacar que há entendimentos doutrinários que destoam o ora esposado, entendendo-se pela distinção entre a fase procedimental fiscalizatória e a fase processual administrativa na seara tributária. Nesse sentido, confira-se James Marins, Direito Processual Tributário Brasileiro, p. 201. Nos dizeres do autor, "O processo administrativo tributário" refere-se ao conjunto de normas que disciplina o regime jurídico processual-administrativo aplicável às lides tributárias deduzidas perante a administração pública. $\mathrm{O}$ procedimento fiscal tem caráter 'fiscalizatório' ou 'apuratório' e tem por finalidade preparar o ato de lançamento".
} 
Três aspectos devem ser ressaltados nessa conceituação: (i.) ter como ponto de partida a decisão estatal - o provimento; (ii.) integrar o procedimento ao conceito de processo; (iii.) ressaltar o contraditório como essencial ao modelo judicial de solução de controvérsias.

(...)

Muito embora seja possível, em outros campos, conceber procedimento ou processo sem decisão, como, por exemplo, em relação a um processo industrial de produção de um determinado bem. Mas nesse caso, sem dúvida não há interesse jurídico, pois este tem na decisão elemento fundamental.

A integração do procedimento ao conceito de processo, também, é algo de fundamental importância . Afinal a referida conceituação pandectista, do processo como relação jurídica processual, ignora o procedimento como integrante da definição de processo. O procedimento, como conjunto ordenado de atos voltados a determinado fim, aparece apenas com a maneira pela qual o processo se exterioriza.

É possível ter-se procedimento sem processo, mas não o contrário.

Dependendo do atributo escolhido como definidor do que venha a ser processo - o contraditório, no caso da conceituação examinada - pode o procedimento deixar de ser caracterizado como tal. Digamos, por exemplo, uma investigação administrativa preliminar, ainda não aberta à participação dos interessados.

Contrariamente, no entanto, não é possível conceber-se processo sem procedimento. Mesmo o conceito de processo como relação jurídica, não faria sentido se ela não se desenvolvesse por meio de um procedimento. À falta deste ultimo esvazia-se o próprio conceito e conteúdo de processo.

O problema que se coloca, então, é que igualar, pura e simplesmente, processo a procedimento implica a uma conceituação demasiadamente ampla, remetendo a fenômenos destituídos de caráter normativo, estranhos ao universo jurídico.

Por essa razão, a conceituação acima transcrita adiciona ao procedimento o requisito do contraditório, muito embora não o faça expressamente sob esse fundamento. Processo, sob essa perspectiva, não seria qualquer procedimento, mas apenas aquele desenvolvido mediante contraditório, com a participação dos interessados no "provimento", isto é, no ato final cujos efeitos recairão sobre na esfera jurídica dos participantes". ${ }^{102}$

Odete Medauar, ${ }^{103}$ ao analisar especificamente a processualidade tributária, esclarece que o termo processo não necessariamente estará relacionado ao processo judicial estatal, na medida em que, sob o enfoque do contencioso tributário, há processo administrativo na medida em que as partes (particular e fisco) atuam em contraditório contrapondo seus interesses.

O entendimento de que, mesmo no procedimento fiscalizatório, poderemos falar na existência de processo decorre não só da previsão ritual normativa, mas também da existência de elementos do contraditório ${ }^{104}$ no procedimento de fiscalização na medida em que o contribuinte poderá receber intimações e termos e tem a oportunidade de responder à autoridade fiscal.

${ }^{102}$ P. $100 / 101$.

${ }_{103}^{103}$ A Processualidade administrativa tributária, p. 428-429.

${ }^{104} \mathrm{De}$ fato, durante a fiscalização, o contribuinte é intimado a apresentar documentos e informações relativos aos fatos investigados e, nesse sentido, pode responder expondo seus pontos e contrapontos ao quanto alegado pela fiscalização. O contraditório, ou princípio da audiência bilateral, estabelece comunicação idônea entre as partes envolvidas (nesse sentido, Cleide Previtalli Cais, O processo tributário, p. 103 e, a despeito de em certos momentos as oportunidades de manifestação do contribuinte serem limitadas, não há como afastar por completo a existência do contraditório. 
A partir dessa concepção funcional no sentido de que o procedimento decisório dotado de normatividade, ${ }^{105}$ bem como diante da presença do contraditório, segue-se pela característica processual, e não meramente procedimental, da fiscalização tributária não meramente destinada ao exercício do poder de polícia.

Importante salientar que o procedimento de fiscalização não se confunde com o ato de lançamento, privativamente realizável pela autoridade administrativa e consistente na efetiva consecução do ato que constituirá o crédito tributário, com previsão normativa no artigo 142 do CTN. A conclusão da fiscalização será o encerramento do procedimento sem qualquer ônus ao contribuinte ou, caso irregularidades sejam apuradas, lavrar-se-á a autuação fiscal.

Feitas essas observações acerca da possibilidade de entendimentos entre o fisco e contribuinte antes mesmo da constituição do crédito tributário, vale tratar das formas de solução de controvérsias aplicáveis quando já ocorrido o fato gerador.

\subsubsection{Métodos para questionar o crédito tributário já constituído}

A partir do momento em que o crédito tributário já se encontra formalmente constituído (ou no momento de sua consecução), podemos falar na fiscalização, no processo administrativo e no processo judicial. ${ }^{106}$

A fiscalização poderá, caso encontradas inconsistências pelo fisco, resultar na lavratura de auto de infração e, nesse caso, o contribuinte será intimado para defender-se

${ }^{105}$ Cf. Carlos Alberto de Salles, Arbitragem em contratos administrativos, p. 104.

106 James Marins considera que o momento anterior à constituição do crédito tributário consiste em procedimento e os meios procedimentais administrativo e judicial podem ser considerados os processos relacionados às controvérsias tributárias. Assim o autor resume seu entendimento:

" $1^{\circ}$ procedimento enquanto caminho para consecução de ato de lançamento (inclusive fiscalização tributária e imposição de penalidades);

$2^{\circ}$ processo como meio de solução administrativa dos conflitos fiscais. $e$

$3^{\circ}$ processo como meio de solução judicial dos conflitos fiscais." (In Direito Processual Tributário

Brasileiro (Administrativo e Judicial), p. 162). 
ou efetuar o pagamento do débito. Importa destacar que o ato de lançamento pode ou não ser precedido de fiscalização. ${ }^{107}$

Nesse momento surge uma das mais populares hipóteses de transação entre fisco e contribuinte, na medida em que quando do recebimento da autuação fiscal, normalmente o contribuinte tem a opção de efetuar o pagamento do débito com redução da multa aplicada pelo fisco. ${ }^{108}$

Caso o contribuinte opte por questionar a exigência, instaura-se o processo administrativo mediante apresentação da Impugnação, percorrendo-se as diversas instâncias administrativas. ${ }^{109}$

Sobre o processo administrativo em geral, vale destacar as vantagens que deságuam no adequado desempenho da função administrativa, trazidas por Odete Medauar: ${ }^{110}$ equilíbrio entre a autoridade do sujeito público e os direitos dos particulares, o encontro de pontos de vista e interesses diversos daquele assumido pela própria administração e a presente necessidade de que sejam considerados interesses e direitos co-presentes na situação.

Importa salientar que muito se discute na doutrina acerca da coisa julgada administrativa na hipótese de ser o contribuinte vencedor. Poderia o fisco levar a decisão proferida na sede da administração fiscal para revisão jurisdicional? ${ }^{111}$ Marciano Siqueira

\footnotetext{
${ }^{107}$ Para detalhes sobre o assunto, vide James Marins, Direito Processual Tributário Brasileiro, p. 204.

${ }^{108}$ No âmbito federal, a redução é regulamentada pela Lei $\mathrm{n} \stackrel{\circ}{-} 8.218$, de 1991 , art. $6^{\circ}$, com a redação dada pela Lei $\mathrm{n}^{\circ}$ 11.941, de 2009, art. 28; Lei $\mathrm{n}^{\circ}$-9.430, de 1996, art. 44, § $3^{\circ}$. No âmbito das fazendas estaduais, a título exemplificativo, anotem-se as reduções: Artigo 127, I, "b" da Lei Estadual do Estado do Ceará $\mathrm{n}^{\circ}$. 12.670/96, com redação da Lei Estadual no. 13.418/03; art. 40, parágrafo único da Lei do Estado do Paraná n. 11.580/1996; Lei do Estado de Pernambuco n. 10.654/91; dentre outras normas.

109 Sobre o processo administrativo tributário, confira-se: James Marins, Direito processual tributário brasileiro (administrativo e judicial), p. 153-371; Marcos Vinícius Neder e Maria Teresa Martinez Lopez, Processo administrativo federal comentado.

${ }^{110}$ Processualidade no direito administrativo. São Paulo: Editora Revista dos Tribunais, 1993, p. 66.

${ }^{111}$ Um dos aspectos em que se levanta a possibilidade de revisão judicial da decisão tributária administrativa favorável ao contribuinte reside na ocasião em que os julgadores administrativos declarem inconstitucionalidade de lei ou ato normativo, na medida em que tal prerrogativa seria exclusiva do Judiciário. Outro aspecto comumente analisado pela doutrina é a possibilidade de revisão judicial da decisão administrativa quando inexiste recurso hierárquico oponível no próprio seio da administração. O STJ entende que o Ministro poderá rever a decisão administrativa excepcionalmente, e sempre em respeito ao contraditório. Confira-se:
} 
de Godoy afirma que "se a pessoa jurídica de Direito público chegou à conclusão - por órgãos especializado e ao cabo de um processo regular previsto em lei -que não the assiste determinado direito creditório frente ao particular, essa mesma pessoa jurídica de Direito público não pode buscar a invalidação judicial daquele reconhecimento de partiu de si mesma". 112

Caso o contribuinte seja vencido, a via judicial poderá ser instaurada quer pelo contribuinte, quer pelo fisco, para discussão judicial acerca da existência e validade do crédito tributário.

A doutrina ${ }^{113}$ costuma classificar as ações tributárias em exacionais (ou seja, nas quais o sujeito ativo é parte ativa na ação, tais como ação de execução fiscal, medida cautelar fiscal, ação direta de inconstitucionalidade, ação direta de inconstitucionalidade por omissão, ação declaratória de constitucionalidade ou ação popular) ou antiexacionais (o sujeito passivo da relação tributária é ativo no processo, tais como ação anulatória de débito, fiscal, mandado de segurança, ação cautelar, ação declaratória de inexistência da relação jurídico-tributária, ação de repetição de indébito, ação direta de inconstitucionalidade, ação direta de inconstitucionalidade por omissão, ação declaratória de constitucionalidade e mandado de injunção).

\footnotetext{
“TRIBUTÁRIO - PROCESSO ADMINISTRATIVO - TRIBUTÁRIO - RECURSO DE OFÍCIO: FINALIDADE - REVISÃO ADMINISTRATIVA DA DECISÃO DO CONSELHO DE CONTRIBUINTES.

1. O Código Tributário do Estado do Rio de janeiro permitia o chamado recurso hierárquico (art. 266, $\S 2^{\circ}$ da Lei 3.188//99), plenamente aceito pelo STJ (precedente da 1a. Seção, relator Min.

Humberto Gomes de Barros)

2. O recurso hierárquico permite ao Secretário da Fazenda rever a decisão do Conselho de Contribuintes e impugná-la se eivada de vícios ou nulidades patentes e devidamente identificadas.

3. O recurso hierárquico não rende ensejo a que a autoridade administrativa, por deleite ou por mero capricho, venha a desfazer a decisão do colegiado.

4. Recurso ordinário provido." (RMS 16.902. 2a Turma. Rel. Ministra ELIANA CALMON. J. 19/08/2004. DJ 04/10/2004 p. 220).
}

A $1^{\text {a }}$ Seção do STJ decidiu que o Ministro de Estado não poderia anular decisões administrativas por falha de fundamentação e a fiscalização busca, por tal razão, atingir o Judiciário. Nesse sentido, vide Parecer PGFN 1.087 (DOU de 23.08.2004).

${ }^{112}$ Sobre a possibilidade de a Fazenda Pública reverter, em juízo, decisões definitivas dos Conselhos de Contribuintes, p. 410.

${ }^{113}$ Por todos, vide James Marins, Direito processual tributário brasileiro, p. 413-419. Há, outrossim, classificação acerca da existência de regramento próprio, sendo próprias a execução fiscal e respectivos embargos, bem como a medida cautelar fiscal. 
Tanto na ação anulatória de débito fiscal ${ }^{114}$ (ajuizada pelo contribuinte) quanto nos Embargos opostos à Execução Fiscal ${ }^{115}$ há cognição exauriente e possibilidade de ampla dilação probatória, o que é por demais das vezes essencial para a definição acerca da validade, ou não, da cobrança.

O fisco é legítimo, outrossim, para ajuizar medida cautelar fiscal nas hipóteses taxativamente previstas na Lei 8.397/1992, após constituição do crédito. Importa salientar que vem sendo prática corrente da Procuradoria-Geral da Fazenda Nacional o ajuizamento da medida cautelar fiscal antes mesmo da definitiva constituição do crédito tributário na esfera administrativa (ou seja, enquanto pende de julgamento o processo administrativo tributário) em casos cuja situação fática, no seu entender, assim justificam, tendo havido aval da jurisprudência quanto ao excepcional cabimento do procedimento.

Mas o processo judicial tributário pode ser intentado pelo contribuinte preventivamente à existência do débito fiscal, mediante ajuizamento de Mandado de Segurança, Medida Cautelar ou mesmo ação declaratória preventiva.

O Mandado de Segurança é amplamente utilizado por advogados tributaristas, sobretudo diante da possibilidade de decisão mandamental que impeça o exercício da atividade dos agentes fiscais e, ademais, em vista da inexistência de condenação da parte vencida ao pagamento de honorários sucumbenciais. ${ }^{116}$

O procedimento cautelar, no passado, era muito utilizado para fins de apresentação de garantia como forma de suspender a exigibilidade do crédito tributário e, após advento da Lei 8.952/1994, que inseriu a possibilidade de antecipação dos efeitos da tutela em medida judicial de rito ordinário, caiu de certa forma em desuso.

\footnotetext{
114 A ação anulatória pode vir combinada com pedido declaratório, visando ao atingimento de fatos geradores futuros pelo provimento jurisdicional a ser formulado.

${ }^{115} \mathrm{O}$ executivo fiscal é regulado pela Lei das Execuções Fiscais (Lei n. 6.830/80), a despeito de a certidão da dívida ativa se encontrar no rol dos títulos executivos constante do CPC (art. 585, VII).

A defesa do Executado é apresentada mediante oposição de Embargos à Execução Fiscal e adicionalmente às previsões específicas da Lei das Execuções Fiscais (“LEF”), aplica-se subsidiariamente o CPC.

${ }^{116}$ Vale mencionar que o STF possui entendimento no sentido de que o Mandado de Segurança é remédio processual adequado para tratar de questão de direito (Súmula 625) e próprio Superior Tribunal de Justiça já sumulou a viabilidade da via mandamental para viabilizar a compensação tributária (Súmula 213). Muito embora, nesses casos, o Mandado de Segurança não seja destinado à homologação da compensação, trata-se de possível instrumento para garantir ao contribuinte o direito de se utilizar de determinado recolhimento indevido, por exemplo, em razão da inconstitucionalidade da cobrança.
} 
Aplicação interessante da medida cautelar na seara tributária é a possibilidade de o contribuinte ajuizar medida cautelar para antecipação da garantia a ser oportunamente transferida à ação executiva fiscal que será proposta pelo fisco, como forma de viabilizar a emissão de certidão positiva de débitos com efeitos de negativa. ${ }^{117}$

Importante salientar que o processo judicial tributário não apenas trata de questionar o crédito tributário em si, pois há questões paralelas, do dia a dia dos contribuintes, que acabam sendo comumente levadas ao judiciário, a exemplo do que ocorre com as medidas intentadas para garantia de emissão de certidão negativa de débitos fiscais (artigos 205 e 206 do CTN).

\subsection{O processo, os métodos alternativos e o direito tributário}

A sociedade espera que o direito seja capaz de solucionais os mais diversos conflitos, ainda que não previsíveis, bem como que a resposta se dê de forma a não empacar a velocidade das relações havidas na sociedade informacional. ${ }^{118}$ Como afirma Mauro Cappelletti, "em certas áreas ou espécies de litígios, a solução normal - o tradicional processo litigioso em juízo - pode não ser o melhor caminho para ensejar a vindicação efetiva de direitos". 119

E nesse sentido, assumindo a definição de Elio Fazzalari acerca do processo,

${ }^{117}$ Aceita pelo STJ, essa ação é absolutamente sui generis na medida em que o autor da ação cautelar não é responsável pelo ajuizamento da ação principal, cuja legitimidade ativa é privativa do sujeito ativo da relação jurídico-tributária. Nesse sentido, menciona-se o Recurso Especial 1.123.669,julgado pela $1^{a}$ Sessão do STJ favorável à espécie cautelar ora mencionada e submetido ao regime do artigo 543-C do CPC.

${ }^{118}$ José Eduardo de Faria trata da crise dos mecanismos de solução de conflitos:

"progressivo esgotamento tanto da operacionalidade quanto da eficácia dos mecanismos jurídicos convencionais dos Estados - especialmente dos instrumentos legais de regulação e controle econômica e financeira, que não acompanham a velocidade com que as atividades econômicas se globalizam, nas duas ou três últimas décadas do século 20, o mundo se globalizou” (op.cit., p. 35).

119 O Autor trata, especificamente, do terceiro obstáculo ao adequado "acesso à Justiça", a saber, o processual, que se soma aos entraves econômico e organizacional. (In Os métodos alternativos de solução de conflitos no quadro do movimento universal de acesso à justiça, p. 124.). 
"il processo è un procedimento in cui partecipano (sono abilitati a participare) coloro nella cui esfera giuridica l'atto finale è destina a svolgere effetti: in contradittorio, e in modo che l'autore dell'atto non possa obliterare le loro attività. Non basta, per distinguere il processo dal procedimento, il rilievo che nel processo vi è la partecipazione di piu soggetti, che cioè gli atti finale, ma anche da altri soggetti.,"120

É crescente a noção de que tanto a atuação do Estado-juiz quanto sua relação com os jurisdicionados devem ser reguladas para que as soluções sejam prestadas em exata correspondência ao tipo de tutela pleiteada, buscando sempre a forma mais célere e menos onerosa àqueles que buscam a tutela jurisdicional como forma de solução de controvérsias, ${ }^{121}$ sempre com vistas a superar "a crise estrutural do Judiciário". ${ }^{122}$

Nesse sentido, a mera existência de processo judicial posto à disposição dos jurisdicionados pode não mais satisfazer as garantias constitucionais nem tampouco o anseio social por adequados métodos de solução de controvérsias $^{123}$ - isso sem perder de

${ }^{120}$ In Instituzioni di Diritto Processuale, p. 82-83.

Confira-se tradução livre: "O processo é um procedimento em que participam (são habilitados a participar) aqueles cuja esfera legal do ato final é destinado a desempenhar efeitos: no contraditório e de forma que o autor do ato não possa validar suas atividades. Não é suficiente, para distinção do processo do procedimento, a constatação de que o processo é a participação das partes mais, a saber, que os atos finais, mas também por outras entidades."

${ }^{121}$ Importante destacar que a noção de instrumentalidade dos mecanismos processuais em relação ao direito material foi analisada por Carlos Alberto de Salles: "o desenvolvimento mais recente do direito processual reflete a preocupação metodológica de um redimensionamento do objeto de estudo dessa área jurídica, reconhecendo a instrumentalidade dos mecanismos processuais em relação ao direito material. Esse redirecionamento metodológico introduz, como preocupação prioritária, a capacidade do processo de produzir resultados consistentes com as necessidades do ordenamento de direito material. A avaliação desses resultados, por seu turno, somente é possível levando-se em conta os escopos do processo, indicativos das funções a serem por ele exercidas e das finalidades que deve atingir no sistema jurídico e na sociedade" (Processo Civil e interesse público, p. 45-46).

${ }^{122}$ A expressão é utilizada pela Professora Ada Pellegrini Grinover em oportunidades distintas, a saber, A crise do poder judiciário, p.22 e Arbitragem e prestação de serviços públicos, p. 65.

123 “(... com a sentença, não há pacificação do conflito”, como lembra Valeria Ferioli Lagrasta Luchiari in "Gerenciamento do Processo e meios alternativos de solução de conflitos", p. 742.

Na seara tributária, essa realidade é ainda mais peculiar: por exemplo, ao se analisar o entendimento já sumulado pelo Supremo Tribunal Federal: "Decisão que declara indevida a cobrança do imposto em determinado exercício não faz coisa julgada em relação aos posteriores" (Súmula 239). Muito embora não seja razoável utilizar-se da mencionada súmula para limitar a coisa julgada de cunho declaratório que reconhece o direito do contribuinte de adotar certa postura com relação, inclusive, a exercícios posteriores àquele em que for proferida decisão, o intuito da Excelsa Corte ao editar mencionada súmula foi justamente o de frear o indevido aproveitamento em períodos posteriores e fora do objeto do litígio de decisão que reconhece ser determinada cobrança indevida com relação a determinado exercício e em razão de fato certo (vide, sobre o assunto, Walter Piva Rodrigues, Coisa Julgada Tributária, pp.107-108 e também nosso Coisa Julgada Tributária).

Vale transcrever trecho do julgado que originou a súmula: "Não alcança os efeitos da coisa julgada em matéria fiscal, o pronunciamento judicial sobre nulidade do lançamento do imposto ou da sua prescrição referente a um determinado exercício, que não obsta o procedimento fiscal nos exercícios subsequentes" (STF. Tribunal Pleno. Agravo de petição no 11.227. Rel. Min. Castro Nunes. J. 05.06.1944). 
vista a necessária vinculação dos métodos aos princípios e valores constitucionais vigentes. $^{124}$

\author{
Como ressalta Carlos Alberto de Salles, ${ }^{125}$
}

como as normas processuais surgem em resposta a um problema central do direito moderno, as concepções sobre relação entre direito e processo acabam por se tornarem indicativas, além do mais, do entendimento sobre o próprio papel do direito e da atividade judicial na sociedade. Nesse enfoque, o estudo do processo coloca-se sob uma perspectiva funcional, isto é, voltada à compreensão da função de seus institutos nos vários contextos nos quais estão inseridos, destacando dessa maneira sua relação com o ordenamento jurídico e com os sistemas político, econômico e social.

E como salienta Kazuo Watanabe, a despeito de o sistema vigente prestigiar os meios alternativos de solução de controvérsias, "a mentalidade forjada nas academias, $e$ fortalecida na práxis forense, que é aquela já mencionada de solução adjudicada autoritariamente pelo juiz,por meio de sentença, mentalidade essa agravada pela sobrecarga excessiva de serviços que têm os magistrados, vem fazendo com que os dispositivos processuais citados sejam pouco utilizados". ${ }^{26}$

Sob essa perspectiva de efetividade dos meios fornecidos pelo Estado aos jurisdicionados para solução de conflitos, em vista da realidade do contencioso tributário judicial atualmente enfrentado pelos contribuintes e pelos fiscos brasileiros, também em matéria tributária passa a ser louvável a "revisitação de equivalentes jurisdicionais, como a heterocomposição, na busca de meios alternativos ao processo". ${ }^{127}$

No entanto, cabe brevemente refletir se o teor da decisão que reconhece indevido o tributo em determinado exercício poderia ou não ser aplicado a exercícios diversos, desde que a cobrança ocorresse com base no mesmo fundamento legislativo e diante de igual situação fática. Em termos práticos, ainda que o contribuinte tenha reconhecido, por exemplo, seu caráter imune com relação a determinada relação jurídico-tributária, caso a decisão não possua cunho declaratório será necessário ajuizar demandas idênticas para reconhecimento da imunidade com relação a períodos diversos. Tal fenômeno certamente contribui para a existência de ações repetitivas perante as cortes pátrias.

${ }^{124}$ Como ressalta Owen Fiss, o juiz muito mais do que proporcionar a solução de conflitos, deve dar voz aos princípios constitucionais (As formas de justiça, in Um novo processo civil: estudos norte-americanos sobre jurisdição, constituição e sociedade, p. 25 e ss).

Válidos nesse aspecto os ensinamentos de Abram Chayes ao analisar o papel dos magistrados nos litígios de direito publico. Ao estudar o papel das provas, o jurista ressalta o impacto das evidências e fatos em relação às consequencias legais a serem consideradas: "The extended impact of the judgment demands a more visibly reliable and credible procedure for establishing and evaluating the fact elements in the litigation, and one that more explicitly recognizes the complex and continuous interplay between fact evaluation and legal consequence" (The role of the judge in public law litigation, p. 1.297).

${ }^{125}$ Processo civil e interesse público, p. 41-42.

${ }^{126}$ Cultura da sentença e cultura da pacificação, p. 686.

${ }^{127}$ The role of the judge in public law litigation, p. 22. 
Já em 1988 Geraldo Ataliba defendia a necessidade de se criarem mecanismos alternativos ao judicial para solucionar os conflitos tributários, ${ }^{128}$ na medida em que "se todas as divergências forem submetidas ao Poder Judiciário, este submergirá sob o peso de um acúmulo insuportável de questões para julgar. Além disso - e também por isso tardarão muito as soluções, em detrimento das partes envolvidas". ${ }^{129}$

A partir de uma análise das profundas mudanças econômicas surgidas no Estado, que refletem intimamente na noção do Estado e na sua própria relação com os administrados, aliada à atual situação das controvérsias tributárias levadas à solução judicial de controvérsias, o estudo visa avaliar, sob enfoque processual, a adequação e necessidade de que meios alternativos de solução de controvérsias sejam adotados no Brasil no campo tributário. ${ }^{130}$

Como se vê, inquietação acerca da possibilidade e viabilidade processual de métodos distintos do adjudicado em sede de controvérsias tributárias alinha-se à tendência da ciência processual civil, pois "fundamental importância para a transformação social, com a mudança de mentalidade, propiciaria uma solução mais adequada aos conflitos, com a consideração das peculiaridades e especificidades dos conflitos e das pessoas neles envolvidas". 131

Nesse passo, sem prejuízo das recentes medidas visando aprimorar e agilizar o andamento das demandas judiciais, ${ }^{132}$ questiona-se a possibilidade de que métodos

\footnotetext{
${ }^{128}$ Afirmava o Professor que "diversas razões recomendam que se crie um sistema de eliminação célere e eficaz desses conflitos, tendo em vista a harmonia fisco-contribuinte e os interesses em jogo" (in Recurso em matéria tributária. Revista de informação legislativa, v. 25, n. 97, p. 122).

${ }^{129}$ Recurso em matéria tributária, p. 122.

${ }^{130}$ Acerca da possibilidade de a lei vir a prever e regulamentar métodos alternativos para solução de conflitos tributários, vale transcrever o entendimento de Heleno Taveira Torres:

No campo da aplicação, nada impede que a lei possa qualificar, dentro de limites e no atendimento do interesse coletivo, os melhores critérios para constituição, modificação ou extinção do crédito tributário, inclusive os meios de resolução de conflitos, vinculativamente e com espaço para discricionariedade, no que couber, visando a atender à praticabilidade, economicidade, celeridade $e$ eficiência da Administração Tributária. ("Transação, arbitragem e conciliação judicial como medidas alternativas para resolução de conflitos entre administração e contribuintes - simplificação e eficiência administrativa", p. 56.)

131 Ada Pellegrini Grinover e Kazuo Watanabe, in Política Pública do Poder Judiciário Nacional para tratamento adequado dos conflitos de interesses.

${ }^{132}$ Dentre as recentes reformas da legislação processual civil, vale destacar a atual sistemática de julgamento de recursos às cortes superiores, que passou a exigir a arguição da repercussão geral do julgamento do apelo
} 
alternativos sejam postos à disposição dos jurisdicionados para fins de solução de controvérsias tributárias. ${ }^{133}$

O direito alienígena há muito enfrenta a questão e disponibiliza meios distintos da solução judicial aos conflitos tributários. A experiência estrangeira em soluções alternativas de controvérsias tributárias pode ser estudada, dentre outros, na Itália, Espanha, França, Portugal, Holanda, Inglaterra, Bélgica e Estados Unidos da América.

Quanto às relações internacionais entre países que se envolvam em controvérsias tributárias, a OECD (Organisation for economic co-operation and development), ${ }^{134} \mathrm{em}$ seu "Model Tax Convention", ${ }^{135}$ traz expressamente, no artigo $25,{ }^{136}$ a possibilidade de conflitos de tributação ${ }^{137}$ gerados entre os países membros ou mesmo entre residentes nos países membros e os respectivos fiscos virem a ser decididos por arbitragem. ${ }^{138}$

(em caso de Recurso Extraordinário - artigo 543-A do Código de Processo Civil), bem como a nova sistemática para julgamento de recursos repetitivos pelo Supremo Tribunal Federal (artigo 543-B do Codex). Vale mencionar recente estudo feito por James Marins (Defesa e vulnerabilidade do contribuinte), no qual o autor faz uma análise do princípio da razoável duração do processo no âmbito do processo tributário, analisando recentes alterações processuais e sua influência no direito processual em questão (pp. 59-78 e 123-166).

Humberto Theodoro Junior, in Celeridade e efetividade da prestação jurisdicional. Insuficiência da reforma das leis processuais, p.67-68, analisa as reformas havidas no Código de Processo Civil Brasileiro de 1973 conclui que "não obstante toda essa técnica de modernização processual, a justiça brasileira continua desacreditada aos olhos da sociedade pela excessiva demora na solução dos litígios”.

${ }^{133}$ Essa tendência de busca por meios alternativos à solução de conflitos tributários foi teorizada por Mauro Cappelletti e Bryant Garth, Access to justice dentre uma das ondas renovatórias. Para detalhes, vide Marco Antonio Garcia Lopes Lorencini, "A contribuição dos meios alternativos para a solução de controvérsias"; Arnold Wald Filho, in "Novos rumos para a arbitragem".

${ }^{134}$ Confira-se lista dos países atualmente membros da OECD: Austrália, Áustria, Bélgica, República Checa, Dinamarca, Finlândia, França, Alemanha, Grécia, Hungria, Islândia, Irlanda, Itália, Coréia, Luxemburgo, México,Holanda, Nova Zelândia, Noruega, Polônia, Portugal, República Eslovaca, Espanha, Suécia, Suíça, Turquia, Reino Unido e Estados Unidos da América (fonte: http://www.oecd.org/home/0,2987,en_2649_201185_1_1_1_1_1,00.html, acesso em 26.10.09).

${ }_{135}$ Trata-se de redação sugestiva para tratados internacionais firmados entre países no tocante a questões de tributação.

136 Referido dispositivo estatui que "any unresolved issues arising from the case shall be submitted to arbitration if the person so requests".

${ }^{137}$ A título exemplificativo, a arbitragem pode ser eleita por dois países membros da OECD para resolver questões atinentes à bi-tributação de determinada transação. Essa espécie de arbitragem é comum dentro da Comunidade Européia também por força do disposto na Convenção de Arbitragem da União Européia ("EU Arbitration Convention"), que determina que em caso de conflitos acerca de bi-tributação não resolvidos pelas autoridades competentes dentro de dois anos, contados da apresentação da problemática, o conflito deverá ser resolvido por arbitragem.

138 A despeito da orientação da OECD, poucos tratados para evitar bi-tributação trazem em seu texto a previsão para solução de conflitos por meio da arbitragem. Pode-se citar, a título exemplificativo, os tratados firmados entre Alemanha e Estados Unidos da América, Holanda e Estados Unidos da América, Bélgica e Estados Unidos da América e, ainda, o protocolo firmado entre Estados Unidos da América e Canadá. 
No Brasil não há regulamentação genérica para soluções alternativas às controvérsias tributárias em que o poder público federal se encontra envolvido ${ }^{139}$ quer no âmbito processual (judicial ${ }^{140}$ ou administrativo), quer em caráter preventivo (ou seja, anteriormente à constituição de crédito tributário).

Vale destacar, a esse respeito, entendimento exarado no Parecer AGU/SRG 01/2007, que considerou a Câmara de Conciliação e Arbitragem da Advocacia-Geral da União (CCAF) competente para dirimir conflitos da seara tributária surgidos entre os órgãos da administração pública federal, o qual ressalta a utilidade dos métodos alternativos também na seara tributária:

"diante do contexto que vem sendo configurado, é incontestável que o espectro da Administração Pública Federal, constituem elevados números e implicam significativas sifras os registros que dão conta da perpetuação de conflitos entre Órgãos elou Entidades, enfoque que alberga demandas, em sede judicial ou não, fazendo com o Estado Brasileiro despenda recursos públicos federais para a manutenção de conflitos perante o Poder Judiciário da União, sem a busca de vias alternativas de rápida, simples e eficaz solução, que, em muitas ocorrências, mais implica o estabelecimento do efetivo diálogo inter-institucional". ${ }^{141}$

Sobre o tema, dois projetos de lei em andamento tratam da regulamentação ${ }^{142}$ da transação e conciliação administrativa e judicial dentre as hipóteses de solução de

\footnotetext{
${ }^{139}$ É muito comum no Brasil a criação de anistias pelos fiscos, viabilizando o pagamento de tributos em atraso pelos contribuintes com benefícios específicos. A título exemplificativo, na esfera federal podem ser citadas, dentre outras, a Lei no 9.964, de 10 de abril de 2000, a Lei no 10.684, de 30 de maio de 2003, a Medida Provisória No. 303, de 29 de junho de 2006, a Lei no 10.522, de 19 de julho de 2002 e, ainda, Lei No. 11.941/09. Sobre a natureza de tais programas, vide III.1.6 infra.

${ }^{140}$ Importante salientar que as estatísticas mostram que as soluções alternativas aos conflitos no Brasil é expressiva se comparada à solução adjudicada. "atualmente, no Estado de São Paulo, o Setor de Conciliação e Mediação Pré-processual está instalado em 20 (vinte) Comarcas, nas quais, no período de janeiro de 2006 a janeiro de 2007, 65\% (sessenta e cinco por cento) das audiências realizadas resultaram em acordos.

Por outro lado, nas 76 (setenta e seis) Comarcas nas quais o Setor de Conciliação e Mediação Processual encontra-se em funcionamento, a porcentagem de acordos nas audiências realizadas é de $48 \%$ (quarenta e oito por cento)" (Valeria Ferioli Lagrasta Luchiari, op.cit., p. 749).

Acrescentem-se os conflitos solucionados por arbitragem, que desde o advento da Lei No. 9.307/96 vem sendo cada vez mais utilizada para solução de conflitos (a despeito de já ter tido fundamento desde a Constituição de 1824).

${ }^{141}$ Fls. 17 do mencionado Parecer, exarado no Processo n. 00407.001676/2007-22.

${ }^{142}$ A transação já vem prevista como uma das hipóteses de extinção do crédito tributário no artigo 156, III, do Código Tributário Nacional, a qual, nos termos do artigo 171 do mesmo diploma, depende de regulamentação legal e poderá ser feita para "determinação de litígio e consequente extinção do crédito tributário" (a doutrina entende que o termo "determinação", constante do referido artigo 171, quer em verdade dizer "terminação". Ou seja, pela sistemática do CTN, a transação somente poderia se dar nas hipóteses em que já constituído crédito tributário, não sendo viável, portanto, em caráter preventivo).
} 
controvérsias tributárias (Projeto de Lei No. 5.082/2009 ${ }^{143}$ e Projeto de Lei Complementar No. 469/2009). ${ }^{144}$

Há controvérsia na doutrina brasileira acerca da possibilidade de haver transação ou mesmo conciliação no âmbito tributário, ${ }^{145}$ discussão esta que se estende à possibilidade de haver soluções de controvérsias tributárias através da arbitragem. ${ }^{146}$

Inúmeras questões devem ser enfrentadas para concluir-se pela possibilidade ou impossibilidade de haver soluções alternativas de controvérsias tributárias, dentre as quais se destaca os limites e nuances da (in)disponibilidade ${ }^{147}$ do crédito tributário e do interesse público, na medida em que tal indisponibilidade deve ser analisada num cenário coerente

${ }^{143} \mathrm{Na}$ exposição de motives do Projeto de Lei, verifica-se que se busca a diminuição da litigiosidade e o aumento do cumprimento voluntário das obrigações tributárias, com a eliminação do desperdício de recursos públicos decorrente da sistemática em vigor. Importante esclarecer que o Projeto de Lei vem aliado a outro projeto que trata de reforma ao processo de execução fiscal (cf. Projeto de Lei No. 5.082/2009).

Oportuno salientar que há projetos de lei em tramitação em Estados da Federação, a exemplo do Estado da Bahia, o que viabilizaria a transação relativa a tributos estaduais.

${ }_{144}$ Conforme Projeto de Lei Complementar No. 469/2009.

${ }^{145}$ Confira-se, por oportuno, o entendimento de Paulo Ricardo de Souza Cruz sobre o assunto: “A admitir a possibilidade ampla de transação para solução dos litígios tributários, a tributação deixaria de ser determinada apenas pela vontade da norma, que deve ser geral e abstrata, impessoal e prestigiadora da isonomia, para ser determinada também pela vontade do administrador, com todas as consequências que isso implica, com relação ao aparecimento de subjetividade, com possibilidade de perseguições, arbitrariedades ou favorecimentos” (in “A Transação no Direito Tributário”, p.117 e ss., p. 190, apud GALINARI, Cledson Moreira. Abordagem principiológica e pragmática da transação tributária.).

Em sentido contrário, pela possibilidade de meios alternativos na solução de conflitos tributários, vale citar TORRES, Heleno Taveira: "Temos para nós que o legislador detém, sim, liberdade constitucional para proceder à identificação de métodos alternativos para extinção do crédito tributário, mediante solução de controvérsias em matéria tributária, ao tempo em que, ao fazê-lo deverá predispor, de modo claro, os limites que permitirão aos contribuintes e à Administração alcançarem bom êxito na resolução de conflitos que tenham como objeto matéria de fato de difícil delimitação ou cujas provas apresentadas não permitam a formação de um juízo consistente para identificar a proporção da ocorrência factual ou mesmo a correta quantificação da base de cálculo do tributo. Havendo dificuldades nesses processos lógicos de subsunção, poderia ser útil a utilização de algum desses mecanismos. (...) 'Il 'concordato' non costituisce un 'atto dispositivo' del credito tributario, ma un compromesso sugli aspetti controversi della determinazione dell'imposta'." (Transação, arbitragem e conciliação judicial como medidas alternativas para resolução de conflitos entre administração e contribuintes, p. 50).

Também Aliomar Baleeiro analisou a questão da transação tributária, no tocante à contribuição de melhoria, verbis: "Um campo fecundo de aplicação da transação para término de litígios e extinção de créditos tributários é, parece-nos, a contribuição de melhoria, sobretudo se o Fisco estiver armado do poder de preempção ou prelação, para adquirir o imóvel pelo valor baixo, que o sujeito passivo tende a opor à avaliação oficial, depois de realizada ou iniciada a obra pública” (in Direito Tributário Brasileiro, p. 905).

${ }^{146}$ Importante, nesse momento, esclarecer que a expressão controvérsias é utilizada no presente trabalho para tratar das situações submetidas a mecanismo que vise solucioná-la. Conflito, nesse passo, corresponderia à acepção mais ampla da litigiosidade. Essa mesma concepção foi adotada por Carlos Alberto de Salles, in Arbitragem em contratos administrativos, p. 7-9.

${ }^{147}$ A grafia do prefixo in entre parênteses foi utilizada por Eduardo Talamini no trabalho sobre as nuances e matizes a serem consideradas acerca da real abrangência da indisponibilidade do interesse público (A (in)disponibilidade do interesse público: consequências processuais - composição em juízo, prerrogativas processuais, arbitragem e ação monitória). 
com a atual realidade social e em vistas a trazer soluções satisfatórias em se tratando de efetividade da arrecadação.

Adicionalmente, será necessário analisar as disposições do próprio Código Tributário Nacional (lei recepcionada pela Constituição Federal vigente com status de lei complementar) sobre o tema, por tratar-se do instrumento legislativo competente para legislar sobre questões gerais em matéria tributária.

Sobretudo, os aspectos processuais dos meios alternativos à solução de controvérsia serão avaliados com especial enfoque, de modo a permitir a conclusão acerca de sua viabilidade ou inviabilidade no campo de direito material eleito.

Em suma, o estudo que se pretende, partirá da análise do atual modelo Estatal supra desenvolvida, decorrente das profundas transformações econômico-sociais e, em vista da situação das demandas tributárias que aguardam solução judicial, avaliará a adequação e viabilidade da introdução de meios alternativos à solução de controvérsias na seara tributária.

Nesse sentido, importante avaliar se a natureza do crédito tributário permite que as controvérsias que o envolvem sejam solucionados por métodos distintos do judicial, o que faremos a partir da verificação da arbitrabilidade e transigibilidade das controvérsias tributárias. 


\section{PARTE II - ARBITRAGEM}

\section{CAPÍTULO 1 - ARBITRABILIDADE DAS CONTROVÉRSIAS TRIBUTÁRIAS}

A arbitragem é meio heterocompositivo de solução de controvérsias na medida em que as partes não chegam a um acordo, mas têm a solução do conflito imposta pelo árbitro (ou pelo tribunal arbitral) e, por terem optado pela solução mediante arbitragem, submeterse-ão ao quanto decidido pelo(s) terceiro(s) nomeado.

Diferentemente da jurisdição estatal, a arbitragem é adotada por opção das partes envolvidas no conflito e somente será instituída mediante expressa manifestação de ambos os envolvidos. A jurisdição estatal, a seu turno, é imposta pelo Estado como meio para solucionar controvérsias e, provocado por qualquer pessoa, ${ }^{148}$ submete a parte contrária involuntariamente ao procedimento, não podendo deixar de proporcionar solução à lide que tenha sido instaurada. ${ }^{149}$

A doutrina britânica aponta outro aspecto de especial diferenciação entre a jurisdição estatal e a arbitragem: ${ }^{150}$ pela solução judicial do conflito, o julgador é imposto às partes pelo Estado; já em se tratando de solução por arbitragem, as partes têm a opção de escolha dos árbitros ou, alternativamente, podem apontar a forma de eleição daqueles que imporão a solução da controvérsia. ${ }^{151}$

\footnotetext{
${ }^{148}$ Física, jurídica, de direito público ou privado.

${ }^{149}$ A inafastabilidade da jurisdição encontra-se prevista no artigo $5^{\circ}, \mathrm{XXXV}$ da Constituição Federal, a qual expressamente prevê que "a lei não excluirá da apreciação do Poder Judiciário lesão ou ameaça a direito". ${ }^{150}$ Como apontam Susan Blake, Julie Brown e Stuartt Sime, "arbitration differs from litigation in two main respects:

- $\quad$ a dispute will only be referred to arbitration if that is the course agreed between the parties; and

- $\quad$ arbitrators are appointed by the parties (or through a mechanism agreed by the parties), whereas in litigation the judge will be appointed by the state." (In A practical approach to Alternative Dispute Resolution”, p. 372).

151 Importante salientar a possibilidade de cláusula vazia para a arbitragem. Sobre método de eleição de árbitros, vide abaixo II.2.7.2.
} 
A tradição ${ }^{152}$ brasileira é pela solução judicial das controvérsias, sobremaneira os de ordem tributária, aliada à possibilidade de instauração de contencioso administrativo ${ }^{153}$ perante órgãos julgadores vinculados à administração pública. ${ }^{154}$

No entanto, como bem ressalta Ada Pellegrini Grinover, ${ }^{155}$ os métodos heterocompositivos e autocompositivos de solução de controvérsias, tradicionalmente adotados por sociedades primitivas ${ }^{156}$, vem ganhando espaço no Brasil devido à crise no judiciário ${ }^{157}$ e a tendência é de que a busca por solução diversa da jurisdicional se acentue.

Em se tratando de controvérsias tributárias, diante do atual estágio dos litígios pendentes ${ }^{158}$ mostra-se necessária a adoção de métodos além daqueles hodiernamente disponíveis, pois como salienta José Casalta Nabais ${ }^{159}$, a adequada solução de litígios somente existirá na medida em que o número de litígios seja compatível com a capacidade de resposta do sistema posto para solução. Como visto acima ${ }^{160}$, atualmente no Brasil o Judiciário não vem sendo capaz de adequadamente solucionar as controvérsias tributárias e, desse modo, é essencial que haja métodos alternativos à disposição do físco e do contribuinte para o adequado tratamento dos conflitos, dentre os quais ora se menciona a arbitragem.

Resta investigar se as questões tributárias e o crédito tributário podem ser submetidos à arbitragem.

\footnotetext{
152 Miguel Reale destaca que no Brasil predomina a cultura da arbitragem como método excepcional de técnica de solução de conflitos, afirmando que "é crença predominante, nos círculos empresariais e até mesmo na classe dos advogados, que o processo de arbitragem seria mais propriamente destinado aos negócios internacionais, e quando estiverem em jogo questões de apurada técnica, cujo julgamento exija altos conhecimentos especializados tanto dos peritos, que geralmente atuam no foro, quando dos magistrados", ressaltando após a já real e necessária mudança de perspectiva (in Crise da Justiça e Arbitragem, p. 319).

${ }^{153}$ Sobre meios de solução de controvérsias tributárias já em vigor, vide I.3.2 acima.

${ }^{154}$ A despeito da composição paritária de alguns tribunais, não há independência da administração pública na medida em que os tribunais julgadores são parte dos órgãos respectivos. Assim, por exemplo, o Conselho Superior de Recursos Fiscais (CSRF) é parte da administração tributária federal; o Tribunal de Impostos e Taxas (TIT) compõe a administração tributária do Estado de São Paulo.

${ }^{155}$ Os fundamentos da Justiça conciliativa, p. 16.

${ }^{156}$ A arbitragem já era praticada na Grécia antiga, como salientam Susan Blake, Julie Borwne e Stuart Sime, op. cit., p. 372.

${ }^{157}$ Especificamente sobre a crise dos processos judiciais tributários, vide I.2 acima.

${ }^{158}$ Cf. I. 1 supra.

${ }^{159}$ José Casalta Nabais, Reflexão sobre a introdução da arbitragem tributária, p. 24.

${ }^{160}$ Item I.2 supra.
} 
Jeffrey Owens, ${ }^{161}$ então diretor do Centro para Políticas Tributárias e Administração da $\mathrm{OECD}^{162}$ defendeu que a arbitragem fosse mencionada no Modelo de Convenções da OECD, o qual é comumente utilizado para fins de elaboração de tratados internacionais firmados entre países para solucionar questões tributárias e evitar bitributação. Para Owens, a previsão da arbitragem no modelo é recomendável para proporcionar a solução de conflitos mais eficientemente. ${ }^{163}$

Em se tratando de conflitos internos no Brasil, a Lei de Arbitragem ${ }^{164}$ estabelece, em seu artigo $1^{\circ}$, que pessoas capazes de contratar submetam litígios relativos a direitos patrimoniais disponíveis à solução arbitral.

O Código Civil, a seu turno, admite compromisso judicial ou extrajudicial para solução de litígios entre pessoas "que podem contratar" 165 , veda a possibilidade de firmarse compromisso para "solução de questões de estado, de direito pessoal de família e de outras que não tenham caráter estritamente patrimonial"166 e admite, em contratos, a cláusula compromissória ${ }^{167}$.

Ou seja, a capacidade da pessoa e a disponibilidade do direito (patrimonial) são os dois aspectos que, nos termos da legislação em vigor, definiriam ou não pela possibilidade de adoção da arbitragem para solucionar determinado conflito ${ }^{168}$.

\footnotetext{
${ }^{161}$ In Jeffrey Owens. OECD Proposal to improve the resolution of tax treaty disputes. EuropeanTaxation. June 2007.

162 Organização para a Cooperação e Desenvolvimento Econômico (Organisation de coopération et de développement économiques), com sede em Paris, França (http://www.oecd.org/), é composta por 34 países membros (o Brasil não PE membro) e tem por objetivo promover políticas para melhorias econômicas e sociais às pessoas do mundo todo ("The mission of the Organisation for EconomicCo-operation and Development (OECD) istopromote policies thatwill improve the economic and social well-being of peoplearound the world, http://www.oecd.org/about/, acesso em 10.02.2013) .

${ }^{163}$ A arbitragem é atualmente adotada no Modelo de convenções, cf. artigos 25, para solução de conflitos que tratem de bi-tributação internacional. Os tratados assinados pelo Brasil não mencionam a arbitragem como meio viável para solução de eventuais conflitos (disponíveis em http://www.receita.fazenda.gov.br/Legislacao/AcordosInternacionais/AcordosDuplaTrib.htm; acesso em 24.06.2013).

${ }^{164}$ LA - Lei n. 9.307/96.

${ }^{165}$ Lei $10.406 / 2002$, artigo 851 .

${ }^{166}$ Artigo 852.

${ }^{167}$ Artigo 853

${ }^{168}$ A doutrina trata dos aspectos objetivo e subjetivo da arbitragem.
} 
No entanto, o estudo ora realizado demanda análise de aspectos adicionais para se verificar se as controvérsias tributárias seriam ou não arbitráveis.

A arbitrabilidade pode possuir roupagem diversa se considerado o sistema de civil Law a common Law. Alexandre Monteiro e Leonardo Castro ressaltam que no Brasil o termo arbitrabilidade trata da possibilidade de determinada controvérsia ser solucionada mediante arbitragem. ${ }^{169}$

Carlos Alberto de Sales ressalta que, na literatura jurídica norte-americana, arbitrabilidade, ou arbitrability, seria verificar se a disputa em voga é ou não solucionável mediante arbitragem ${ }^{170} \mathrm{e}$, nesse sentido, a análise seria mais ampla do que a simples averiguação da capacidade das partes e da disponibilidade do direito em disputa.

Carlos Alberto Carmona ${ }^{171}$ salienta que "são arbitráveis, portanto, as causas que tratem de matérias a respeito das quais o Estado não crie reserva específica por conta do resguardo dos interesses fundamentais da coletividade, e desde que as partes possam livremente dispor acerca do bem sobre que controvertem".

A possibilidade de as controvérsias tributárias serem ou não solucionáveis mediante arbitragem encontra, numa análise superficial, óbice em razão da suposta indisponibilidade do crédito tributário; de outro lado, caberia avaliar se o poder público seria ou não capaz de eleger a solução arbitral de conflitos.

No entanto, essa análise não se mostra satisfatória ao quanto ora pretendido, na medida em que aspectos adicionais devem ser avaliados para se verificar a possibilidade ou não de se solucionar controvérsia tributária por arbitragem ${ }^{172}$ - ou para se concluir pela arbitrabilidade, ou não, das controvérsias tributárias no Brasil.

\footnotetext{
169 Alexandre Luiz Moraes do Rêgo Monteiro e Leonardo Freitas de Moraes e Castro, Direito tributário e arbitragem: uma análise da possibilidade e dos óbices ao juízo arbitral em matéria tributária no Brasil, p. 20.

${ }^{170}$ Arbitragem em contratos administrativos, p. 211.

${ }_{171}^{17}$ Arbitragem e processo: um comentário à Lei $n$. 9.307/96, p. 56.

${ }^{172}$ Carlos Alberto de Salles salienta a necessidade de que sejam avaliadas limitações decorrentes de normas vigentes no ordenamento, e não somente normas previstas na lei de arbitragem, para se concluir pela arbitrabilidade de determinado litígio. Como bem salienta, "relativamente á Administração Pública, essa situação é patente, tendo em vista o dato de ela ter a sua atuação regida por diversos condicionantes jurídicos estranhos aos particulares. Mesmo constituindo um instrumento privado de solução de controvérsias, a arbitragem, quando aplicada a contratos administrativos, deve ser realizada com atenção a
} 
Quanto aos requisitos legais postos e também aos institutos intrínsecos à solução privada do conflito envolvendo o Poder Público, é necessária uma avaliação crítica para fins de alcançar uma resposta que, nos termos da atual conjuntura, será satisfatória à conclusão que ora se procura.

Assim, além da disponibilidade do crédito tributário, necessária à aferição do requisito da patrimonialidade necessária à possibilidade de o poder público adotar solução arbitral, e da existência de autonomia da vontade do Estado para conferir solução arbitral à controvérsia tributária, será analisado se o Estado pode renunciar à solução judicial (estatal) para o fim que se avalia, sobretudo à luz da estrita legalidade tributária e, ao final, se as vantagens da arbitragem justificariam a sua adoção.

\subsection{Disponibilidade do crédito tributário}

Muito se discute na doutrina que se propõe a desafiar se seria viável a solução de controvérsia tributária por arbitragem se o crédito tributário é ou não disponível, de forma que, a depender da conclusão a que se chegue, permitir-se-ia, ou não, submissão das controvérsias tributárias a tal modalidade de solução. Questiona-se, no entanto, se a possibilidade de o poder público poder ou não dispor do crédito tributário seria relevante para o objeto do estudo, ou se seu caráter pecuniário bastaria ao atendimento da disponibilidade do objeto para fins de aceitação da arbitragem tributária.

Passa-se, desse modo, a analisar se o crédito tributário é ou não disponível sob a perspectiva do administrador público para, após, adentrar na questão acerca da essencialidade da disponibilidade do crédito tributário como condição viabilizadora da solução arbitral do conflito aqui examinado.

alguns condicionantes do regime de direito público e aplicar a essa modalidade contratual a disciplina jurídica que lhe é especifica” (p. 215). 
A arbitragem é método privado de solução de controvérsias ${ }^{173}$ e há doutrina que não entende viável que o poder público se submeta a tal forma de solução diante da natureza pública do direito em litígio vis a vis a forma privada de solução. ${ }^{174}$

Haja vista a atual concepção de interesse público acima desenvolvida, ${ }^{175}$ não parece que a mera vedação objetiva seja suficiente à conclusão pela inviabilidade da solução arbitral das controvérsias tributárias.

Para tanto, a primeira vertente a ser considerada é o texto constitucional, topo do ordenamento jurídico e ao qual todo o sistema legal tributário se sujeita. Não há, na Constituição Federal, qualquer óbice objetivo à instauração de arbitragem tributária. ${ }^{176}$

Não obstante, o CTN traz a definição do tributo como sendo "toda prestação pecuniária compulsória, em moeda ou cujo valor nela se possa exprimir, que não constitua sanção de ato ilícito, instituída em lei e cobrada mediante atividade administrativa plenamente vinculada”, e justamente a partir de tal definição parte da doutrina repulsa a solução arbitral para controvérsias acerca do tributo diante da sua cobrança decorrer de exercício de atividade vinculada da administração pública.

O interesse público, como visto acima, ${ }^{177}$ não é absolutamente indisponível na medida em que prevalece o interesse da sociedade em detrimento do interesse estatal absoluto. ${ }^{178} \mathrm{O}$ interesse público não necessariamente será o interesse do Estado, na medida

\footnotetext{
${ }^{173}$ Susan Blake, Julie Browne e Stuart Sime salientam que, justamente por força da base contratual da arbitragem, questões de direito público e assuntos conexos, assim como questões que tratam do estado das pessoas, não podem ser solucionadas por arbitragem (A practical approach..., p. 376-377).

${ }^{174}$ Contrários à arbitragem envolvendo o poder público, veja Celso Antonio Bandeira de Mello, Curso de direito administrativo, 2010, p 716-789 e Lucia Valle Figueiredo, Curso..., 2003, p 106.

175 Acima, item I.2.2.

${ }^{176}$ Heleno Taveira Torres (In Princípios da segurança jurídica e transação em matéria tributária. Os limites da revisão administrativa dos acordos tributários, p. 305), exatamente nesse sentido, salienta que a existência de métodos alternativos para solução de conflitos tributários não encontra óbice na Constituição Federal na medida em que não há dispositivo constitucional vedando a sua instituição. Mais adiante, o Professor ensina que os métodos alternativos poderão tratar tanto preventivamente, quanto para solução das lides já pendentes (p. 306).

${ }_{177}$ Item I.2.2.

${ }^{178}$ Ricardo Lobo Torres, (Transação, conciliação e processo tributário administrativo equitativo, p. 107), salienta que "o princípio da supremacia do interesse público gerava a processualidade fundada na superioridade dos interesses da Fazenda Pública. A nova processualidade fiscal pressupõe a crítica vigorosa ao princípio da supremacia do interesse público. Hoje parte importante da doutrina brasileira repeliu a tese da superioridade do interesse público, separando o interesse da Fazenda Pública do interesse público. O
} 
em que há vertentes no direito público que homenageiam o interesse coletivo em detrimento do interesse individual do ente Estatal. Trazendo tal concepção à seara tributária, é possível afirmar-se que não basta arrecadar o tributo; é necessário que a arrecadação se opere de forma justa e coerente com os anseios sociais e com as necessidades da máquina estatal.

Já a atividade de arrecadar o tributo, nos termos do artigo $3^{\circ}$ do CTN, é indisponível na medida em que o administrador não pode abandonar, por caprichos, a função de fiscalizar, lançar e arrecadar o crédito tributário, sob pena de desvio de sua atividade funcional e também da atividade estatal.

Nos termos da definição do CTN acima transcrita, o que é indisponível, de fato, é a atividade de cobrança do crédito tributário, e não o crédito tributário per si. Como salienta Heleno Taveira Torres, ${ }^{179}$ a competência tributária constitucionalmente outorgada ${ }^{180}$ é indisponível, mas isso não significa dizer que o crédito tributário seria igualmente indisponível.

Hugo de Brito Machado é contrário à arbitragem tributária justamente por entender que o direito da Fazenda Pública de arrecadar o tributo seria indisponível e, desse modo, não seria viável a solução das controvérsias tributárias pela via arbitral. ${ }^{181}$

Ousa-se discordar da conclusão acima, pois a plena vinculabilidade da atividade de arrecadação do tributo não significa supor que haja vedação para a disposição do crédito tributário.

Muito pelo contrário, o próprio CTN traz a possibilidade de o crédito tributário ser anistiado, transacionado, remido ou mesmo parcelado, consoante permissão expressa dos artigos 151, 156, 171 e 180. Ou seja, a possibilidade de dispor-se do crédito tributário se encontra prevista no CTN. O que se entende por requisito essencial, de fato, é a plena

interesse fiscal, na época do processo administrativo tributário equitativo, só pode ser o interesse de arrecadar o imposto justo, fundado na capacidade contributiva".

${ }^{179}$ Transação, arbitragem e conciliação judicial como medidas alternativas para resolução de conflitos entre administração e contribuintes - simplificação e eficiência administrativa, p. 56.

${ }^{180}$ Artigos 153, 154, 155 e 156 da Constituição Federal.

181 Transação, arbitragem e conciliação judicial como medidas alternativas para resolução de conflitos entre administração e contribuintes - simplificação e eficiência administrativa, p. 130-134. 
vinculação das hipóteses de renúncia/disposição ao crédito a criteriosos requisitos e critérios legais.

Não faria sentido a letra da lei viabilizar, nos termos em que prevê, que o Estado renuncie ao recebimento do crédito tributário em determinadas situações e, em contrapartida, determinar tratar-se de instituto indisponível, ainda que nos termos da lei. Tal conclusão decorre da própria natureza pecuniária do tributo.

Pedro A. Batista Martins ressalta que os interesses e direitos do Estado que tenham expressão patrimonial são disponíveis ${ }^{182} \mathrm{e}$, a partir dessa premissa, a definição do artigo $3^{\circ}$ do CTN, acima transcrita, qualifica o crédito tributário por disponível.

Assim, o aspecto indisponível mencionado no artigo $3^{\circ}$ do $\mathrm{CTN}$ prescreve não haver possibilidade de a administração pública dispor da fiscalização e arrecadação crédito tributário.

Importa destacar, ademais, que em se tratando do aspecto sobre o qual a administração tributária, nos termos da lei, poderá dispor, haverá manifestação de discricionariedade ${ }^{183}$, dentro dos limites legais. ${ }^{184}$

${ }^{182}$ O Poder Judiciário e a arbitragem: quatro anos da Lei n. 9.307/96 ( $3^{\text {a }}$ parte), Revista Forense, vol. 359, p. 169.

${ }^{183}$ Floriano Azevedo Marques traz interessante análise sobre a interferência do Judiciário na atuação da administração pública por desvio de finalidade do ato, o que se dá mediante verificação da discricionariedade administrativa. $\mathrm{O}$ autor destaca o entendimento jurisprudencial no sentido de que ao Judiciário é vedado adentrar no mérito do ato administrativo e justifica tal posição na possível abertura que tal interferência dará para que se fiscalize também o poder judiciário (Discricionariedade administrativa e controle judicial da administração, in Processo Civil e interesse público. O processo como instrumento de defesa social, p. 194195).

${ }^{184}$ É muito tênue a linha entre aquilo que a administração tributária poderá dispor e o que é absolutamente indisponível em se tratando de tributação. Se a lei permite, por exemplo, renúncia ao crédito tributário, desde que preenchidos os requisitos legais a administração pública poderá conceder o benefício ao contribuinte que se adeque aos critérios definidos pelo legislador. Ou seja, haverá discricionariedade do agente público na medida em que, dentre tantos os contribuintes que possam ser remidos, alguns o serão, quer por iniciativa da administração, quer do próprio contribuinte. De outro lado, verificada a subsunção do fato à norma tributária, o agende público não poderá abrir mão do ato de lançamento tributário.

Vale transcrever as observações de Alberto Xavier a este respeito:

o que não pode é confundir-se, em qualquer caso, o problema da disponibilidade da obrigação tributária, no sentido de idoneidade para constituir objeto de negócios jurídicos, com o problema da discricionariedade administrativa: uma coisa é, na verdade, reconhecer que a obrigação tributária pode ser reduzida, diferida ou modificada pela Administração, outra é dizer que a Administração o pode fazer sempre que o considere oportuno e conveniente. Sento a instituição do imposto reservada à lei, não pode a Administração fiscal gozar de um poder discricionário relativamente aos elementos essenciais da obrigação tributária, cabendo-lhe apenas tais poderes no 
O caráter patrimonial do crédito tributário é inequívoco e decorre da sua função precípua, na medida em que se trata de fonte de custeio para a atividade Estatal e, como tal, propicia recursos financeiros para que o poder público possa exercer suas atividades institucionais. $^{185}$

O entendimento do Superior Tribunal de Justiça, ao julgar a possibilidade de determinada sociedade de economia mista da área portuária solucionar conflito por arbitragem, é justamente no sentido de que a indisponibilidade do interesse público não se confunde com seu caráter patrimonial. ${ }^{186}$ Mutatis mutandi, o entendimento aplica-se integralmente ao crédito tributário, na medida em que seu caráter patrimonial permitirá que o Estado dele disponha, nos termos da lei. Como destaca a ementa do referido julgado, "é assente na doutrina e na jurisprudência que indisponível é o interesse público, e não o interesse da administração”.

Ricardo Lobo Torres ${ }^{187}$, em linha com o entendimento de que a indisponibilidade do crédito tributário não seria absoluta, mas sim permitiria certa margem de disponibilidade por parte do administrador público, ressalta que diante da complexidade do ato de lançamento tributário ${ }^{188}$ há presença na atividade plenamente vinculada e de $(i)$ discricionariedade administrativa, (ii) tipificação administrativa, (iii) casuística e (iv) quantificação.

silêncio da lei, no que concerne aos outros aspectos daquela obrigação, como o modo e o prazo de pagamento (Do lançamento - teoria geral do ato do procedimento e do processo tributário, p. 213).

${ }^{185}$ Importa salientar que o tributo não é a única fonte de sustento do Estado, aliando-se a outras formas de custeio, tais como pagamento pelos serviços prestados pelo Estado ou valores recebidos em desapropriações, dentre outras.

${ }^{186}$ AgRg no MS 11308. Rel. Ministro LUIZ FUX.1 ${ }^{\text {a }}$ Seção. DJ 14/08/2006. No voto do Min. Luiz Fux, hoje membro do Supremo Tribunal Federal, extrai-se que "a arbitragem se presta a dirimir litígios relativos a direitos patrimoniais disponíveis, o que não significa dizer disponibilidade do interesse público, pois não há qualquer relação ente disponibilidade ou indisponibilidade de direitos patrimoniais e disponibilidade ou indisponibilidade de interesse público. Ora, tratar de direitos disponíveis, ou seja, de direitos patrimoniais, significa valer-se da possibilidade de transferi-los a terceiros, porquanto alienáveis. Nesta esteira, salientese que dentre os diversos atos praticados pela Administração, para a realização do interesse público primário, destacam-se aqueles em que se dispõe de determinados direitos patrimoniais, pragmáticos, cuja disponibilidade, em nome do bem coletivo, justifica a convenção da cláusula de arbitragem em sede de contrato administrativo".

${ }^{187}$ Ricardo Lobo Torres, Transação, conciliação e processo tributário administrativo equitativo, pp. 107-108. ${ }^{188}$ Artigo 142 do CTN. 
O que não se pode perder de vista, essencialmente, é a legalidade estrita que norteia toda e qualquer atuação do poder público, mormente em se tratando de aspectos tributários, nos termos dos artigos $5^{\circ}$ e 150 , I da Constituição Federal.

Em outras palavras, a indisponibilidade do crédito tributário, atendendo aos requisitos e premissas legais, estará sempre acompanhada de aspectos intrínsecos que lhe conferirão validade e efetividade.

A possibilidade de o poder público dispor do crédito tributário é efetiva, existente e real, na medida em que o CTN permite a anistia, remissão ou mesmo a transação. A disponibilidade e patrimonialidade necessárias à adoção da arbitragem para solução do conflito tributário, requisitos legais essenciais à definiçãa da arbitrabilidade das controvérsias em exame, se encontram, portanto, presentes. Resta saber se a opção pela solução arbitral acarretará ou não na disposição do crédito tributário, ou se consiste em atendimento do requisito legal.

\subsection{A arbitragem representa disposição do crédito tributário?}

Para se avaliar se seria recomendável ao fisco submeter solução de controvérsia tributária à arbitragem, é importante investigar se tal ato presumiria disposição do crédito tributário ou se o caráter patrimonial do crédito tributário, desvinculado que é da atividade vinculada de apuração, arrecadação e cobrança do tributo, daria atendimento ao critério objetivo para qualificar o crédito tributário como arbitrável.

Ao optarem por submeter a controvérsia tributária ao juízo arbitral, as partes não estão dispondo do direito em discussão, mas somente renunciando à solução jurisdicional estatal do conflito. Ou seja, não se sabe se o resultado será no sentido de conferir o direito integralmente a um dos litigantes, ou parcialmente a ambos, nem há manifestação pela renúncia a parcela do direito em discussão. As partes definem, apenas, que a solução será conferida por uma corte não estatal e que a decisão será vinculante entre as partes. 
Carlos Alberto Carmona ${ }^{189}$ define a arbitragem como sendo "meio alternativo de solução de controvérsia através da intervenção de uma ou mais pessoas que recebem seus poderes de uma convenção privada, decidindo com base nela, sem intervenção estatal, sendo a decisão destinada a assumir a mesma eficácia da sentença judicial - é colocada à disposição de quem quer que seja, para solução de conflitos relativos a direitos patrimoniais acerca dos quais os litigantes possam dispor. Trata-se de mecanismo privado de solução de litígios, através do qual um terceiro, escolhido pelos litigantes, impõe sua decisão, que deverá ser cumprida pelas partes".

Não há, na submissão da solução do conflito por arbitragem, entrega ou renúncia a qualquer direito, mas apenas e tão somente, como define Carmona, submissão do litígio à solução alternativa àquela provida pelo processo estatal. ${ }^{190}$

Desse modo, não parece relevante ser ou não renunciável o crédito tributário para fins de viabilidade da solução arbitral da controvérsia tributária. De fato, o caráter pecuniário do crédito tributário é suficiente à sua admissibilidade objetiva para fins de solução arbitral, ${ }^{191}$ na medida em que ao se optar pela solução arbitral não há renúncia ou disposição de direitos.

E a escolha pela via arbitral se justifica por certas vantagens que podem ser aproveitadas e deverá, por certo, ser avaliada conforme as necessidades e premissas do caso concreto, haja vista que nem sempre corresponderá ao método mais benéfico para solução do determinado conflito. ${ }^{192}$ O Superior Tribunal de Justiça (“STJ”) salienta, em julgado oriundo da Primeira Seção, ser assente na doutrina que

\footnotetext{
${ }^{189}$ In Arbitragem em processo, p. 51.

${ }^{190}$ In Arbitragem em processo, p. 52.

191 A doutrina que aceita a solução arbitral de conflitos contratuais da administração pública aceita, justamente, a possibilidade de se adotar tal método de solução em razão do caráter negocial e patrimonial do contrato administrativo. Nesse sentido, ver Carlos Alberto de Salles, Arbitragem em contratos administrativos, p. 147-148; Paulo Amaral Osternack, Arbitragem e administração pública - aspectos processuais, medidas de urgência e instrumentos, p. 65.

${ }_{192}$ Nesse sentido, vide as vantagens e desvantagens da solução arbitral, II.1.7 infra.
} 
ao optar pela arbitragem o contratante público não está transigindo com o interesse público, nem abrindo mão de instrumentos de defesa de interesses públicos, Está, sim, escolhendo uma forma mais expedita, ou um meio mais hábil, para a defesa do interesse público. Assim como o juiz, no procedimento judicial deve ser imparcial, também o árbitro deve decidir com imparcialidade, $O$ interesse público não se confunde como mero interesse da Administração ou da Fazenda Pública; o interesse público está na correta aplicação da lei e se confunde com a realização correta da Justiça." (grifou-se) (In artigo intitulado"Da Validade de Convenção de Arbitragem Pactuada por Sociedade deEconomia Mista", de autoria dos professores Arnold Wald, Atlhos Gusmão Carneiro, Miguel Tostes de Alencar e Ruy Janoni Doutrado, publicado na Revista de Direito Bancário do Mercado de Capitais e da Arbitragem, $n^{\circ} 18$, ano 5, outubro-dezembro de 2002, página 418.)

12. Em verdade, não há que se negar a aplicabilidade do juízo arbitral em litígios administrativos, em que presente direitos patrimoniais do Estado, mas ao contrário, até mesmo incentivá-la, porquanto mais célere, nos termos do artigo 23 da Lei 8987/95, que dispõe acerca de concessões $e$ permissões de serviços e obras públicas, que prevê em seu inciso $X V$, entre as cláusulas essenciais do contrato de concessão de serviço público, as relativas ao "foro e ao modo amigável de solução de divergências contratuais. ${ }^{193}$

$\mathrm{Na}$ opção pela solução por arbitragem, qualquer das partes envolvidas (poder público ou contribuinte) não estará abrindo mão de parcela do direito em disputa, mas sim estabelecendo que a decisão quanto ao julgamento controvérsia será tomada por tribunal distinto do judicial estatal ${ }^{194} \mathrm{e}$, da mesma forma, vinculará as partes tal como ocorreria com a solução adjudicada judicial.

Assim, irrelevante averiguar acerca da possibilidade de verificar se o fisco pode dispor do crédito tributário como requisito essencial viabilizador da submissão da controvérsia tributária à solução arbitral. Isso decorre não só do fato de a lei já trazer situações consolidadas nas quais o Estado pode dispor do crédito tributário e, desse modo, não basta tal avaliação para se conferir pela possibilidade ou não de adoção da arbitragem como ora se cogita, mas também da desnecessidade de se tratar de direito disponível para fins de instauração da arbitragem.

\footnotetext{
${ }^{193}$ AgRg no MS 11308. Rel. Ministro LUIZ FUX.1 ${ }^{a}$ Seção. DJ 14/08/2006 p. 251.

${ }^{194}$ Justamente nesse sentido, vale transcrever a posição de Adilson Abreu Dallari: "cabe ressaltar que ao optar pela arbitragem o contratante público não está transigindo com o interesse público nem abrindo mão de instrumentos de defesa de interesses públicos. Está, sim, escolhendo uma forma mais hábil para a defesa do interesse público. Assim como o juiz, no processo judicial, deve ser imparcial, também o árbitro deve decidir com imparcialidade. $O$ interesse público não se confunde com o mero interesse da Administração ou da Fazenda Pública; o interesse público está na correta aplicação da lei e se confunde com a realização concreta da justiça. Inúmeras vezes, para defender o interesse público, é preciso decidir contra a administração pública” (Arbitragem na concessão de serviço público, p. 66).
} 


\subsection{Renúncia à jurisdição estatal}

Como visto acima, nossa percepção é de que a disponibilidade (no sentido de irrenunciabilidade) do crédito tributário não interfere na definição acerca da viabilidade, ou não, da adoção da arbitragem para solucionar controvérsias tributárias na medida em que a opção pela arbitragem não implica, sob a perspectiva do fisco (sujeito ativo), na renúncia ao crédito tributário.

Como nos ensina a doutrina italiana de Giovanni Verde, ${ }^{195}$ a análise acerca da viabilidade de o poder público solucionar controvérsias mediante arbitragem depende da possibilidade de ele renunciar à jurisdição estatal.

Adotar a solução arbitral da controvérsia representará, de fato, a renúncia à solução judicial da lide, optando-se por uma solução imposta por um tribunal não estatal (privado), formado de acordo com critérios definidos pelas partes envolvidas nos termos da convenção da arbitragem, e que seguirá o procedimento que se determinar mediante tal convenção, sempre nos termos da lei.

A solução arbitral representa, assim, opt out da jurisdição estatal ${ }^{196}$ para fins de solução da controvérsia ${ }^{197}$ mas, no entanto, não significa dizer que a exclusão da jurisdição estatal será absoluta na medida em que controvérsias surgidas no decorrer do julgamento arbitral podem - e são - comumente levadas ao Judiciário. ${ }^{198}$

Inicialmente, vale fazer breve análise acerca da presença da jurisdição na solução arbitral do conflito, de forma a se concluir se a opção pela arbitragem represente renúncia à jurisdição estatal ou renúncia absoluta a qualquer espécime de jurisdição.

\footnotetext{
${ }^{195}$ Giovanni Verde. Arbitrato e publica amministrazione, p. 215.

${ }^{196}$ Guerrero, Convenção de arbitragem e processo arbitral, p. 125-129 trata do efeito negativo da convenção de arbitragem, referindo-se à opção pela exclusão da jurisdição estatal.

197 Carlos Alberto de Sales, Arbitragem em contratos administrativos, p. 85, salienta a divergência doutrinária acerca do caráter contratual ou jurisdicional da arbitragem.

${ }^{198}$ Nesse sentido, Sales, Carlos Alberto de, Arbitragem em contratos administrativos, p. 37-38.
} 
A doutrina se debruçou sobre a presença de jurisdição na arbitragem e ainda não há consenso sobre o assunto. Os estudiosos mais conservadores entendem ser a jurisdição função exclusivamente Estatal e, portanto, monopólio do Poder Judiciário, sendo inviável pensar em jurisdição exercida por uma corte privada, tal como a arbitral. Mais especificamente sobre a arbitragem tributária, Hugo de Brito Machado ${ }^{199}$ repulsa a presença da jurisdição na arbitragem, justamente por entender se tratar de atividade privativa estatal.

É fato que a arbitragem, tal como hodiernamente regulada, pode ser considerada recente no ordenamento jurídico brasileiro e não surpreende o fato de aqueles mais tradicionalistas afastarem a presença da jurisdição na solução de controvérsias por tribunal privado. No entanto, no atual cenário e diante da crescente participação da solução arbitral para controvérsias, entendemos que o assunto merece cuidadoso exame.

Uma análise histórica da arbitragem é feita por Gilberto Giusti ${ }^{200}$, que conclui pela efetiva existência da jurisdição no julgamento arbitral. Humberto Theodoro Junior ${ }^{201}$ igualmente vislumbra existência de jurisdição no julgamento arbitral por se tratar de decisão tomada por terceiro imparcial.

Carlos Alberto Carmona ${ }^{202}$ faz uma releitura do conceito de jurisdição e advoga pela quebra do entendimento tradicional, no sentido de que somente a justiça estatal estaria imbuída de jurisdição. Para Carmona, a solução arbitral é, sim, dotada de jurisdição, a despeito de seu caráter privado. No mesmo sentido, Selma Lemes ${ }^{203}$ destaca que a jurisdição dos árbitros para solucionar a controvérsia submetida a solução arbitral é outorgada pela convenção de arbitragem.

\footnotetext{
${ }^{199}$ In Transação e arbitragem...., p. 129.

${ }^{200}$ Gilberto Giusti, O árbitro e o juiz: da função jurisdicional do árbitro e do juiz, p. 7-14.

${ }^{201}$ Arbitragem e terceiros. Litisconsórcio fora do pacto arbitral. Outras intervenções de terceiros, p. 49-50.

${ }^{202}$ Arbitragem e jurisdição, p. 33-40. O mesmo autor trata da presença da jurisdição na arbitragem também na obra A crise do processo e os meios alternativos para a solução de controvérsias, p. 93.

${ }^{203}$ Convenção de arbitragem e termo de arbitragem..., p.5.
} 
Carlos Alberto de Salles, ao analisar a viabilidade da arbitragem para solução de controvérsia contratual envolvendo a administração pública, faz uma releitura do conceito de jurisdição, qualificando-a por poder, e diferencia as jurisdições exercidas pelo juiz togado e pelo árbitro daquela presente na atividade dos órgãos administrativos a partir de sua extensão (coercibilidade e vinculatividade) e forma de constituição (consenso entre as partes ou lei). Confira-se:

O elemento distintivo está na impossibilidade de exercício de coerção direta pelos árbitros na imposição do cumprimento de suas decisões. Para tanto, necessária a jurisdição estatal, tendo o monopólio do Estado no uso legítimo da força.

A principal diferença entre a jurisdição do juiz, do árbitro e do órgão administrativo, entretanto, não está localizada na extensão do poder a eles conferido, mas na forma como ele é constituído.

$O$ poder exercido nas decisões estatais, judiciais ou administrativas, é constituído por força de lei, com o mesmo caráter de generalidade próprio aos ordenamentos jurídicos modernos $e$ contemporâneos. Com isso, essa alternativa para solução de controvérsias está aberta para todos os casos em igualdade de condições. A decisão arbitral, contrariamente, é proferida com base em um poder consensualmente atribuído pelas partes ao árbitro, possuindo, de forma diversa àquele estatal, um caráter específico, circunscrito às situações abrangidas pela vontade dos interessados, seja em relação a um contrato (por via da cláusula arbitral), seja em controvérsia já colocada entre as partes (por meio de compromisso arbitral).

Há, portanto, um núcleo comum no poder exercido no âmbito judicial, arbitral ou administrativo. Os diferenciais, de um e de outro, não estão localizados na natureza do poder exercido. Ao contrário, os diferencial sua extensão - quanto à coercibilidade e vinculatividade - e a forma de sua constituição, por lei ou por consenso entre as partes." .204

José Casalta Nabais, ${ }^{205}$ especificamente sobre a introdução da arbitragem tributária, faz um retrospecto da definição de jurisdição e após trazer entendimento pelo seu monopólio estatal, flexibiliza o instituto para afirmar que "nem privatização nem monopólio estadual da justiça". ${ }^{206}$

Como se vê, a partir de uma concepção menos conservadora, a presença de métodos alternativos ao judicial para solução de controvérsias vem sendo cada vez mais adotada e a presença da jurisdição na solução arbitral deve ser considerada, sobretudo diante do poder de a solução arbitral se impor perante as partes, sendo vinculativa no que diz respeito à controvérsia submetida a solução por tribunal privado, quer mediante cláusula compromissória, quer por compromisso arbitral.

\footnotetext{
${ }^{204}$ Arbitragem em contratos administrativos, p. 92.

${ }^{205}$ José Casalta Nabais, Reflexão sobre a introdução da arbitragem tributária, p. 23.

${ }^{206}$ Interessante mencionar que o texto, muito embora tenha lastro no direito lusitano, onde já há lei que trata da arbitragem tributária promulgada (Decreto-Lei n. 10, de 20 de janeiro de 2011), pode ser aplicável ao direito brasileiro na medida em que haja regulamentação legal.
} 
Importa destacar que a opção pela renúncia à jurisdição estatal poderá determinar por vezes a escolha por um método mais qualificado em termos técnicos para solução do conflito, quer em razão de certa tradição do tribunal sobre o mérito a ser discutido, quer em razão da possibilidade de eleger técnicos no assunto para compor o tribunal arbitral. ${ }^{207}$

Conclui-se, assim, que ao optar pela solução arbitral da controvérsia tributária o poder público não estará renunciando em caráter absoluto à jurisdição, mas somente à jurisdição estatal, adequada e mandatória na solução de determinados conflitos mas que, na atual conjuntura, como acima delineado, vem se mostrando morosa e ineficiente, o que enseja a busca por solução perante distinto âmbito jurisdicional.

\subsection{Poder público e arbitragem}

Antes de adentrar na arbitragem tributaria, é importante brevemente refletir sobre a arbitragem nas atividades contratuais do Estado, na medida em que há relevantes pontos de intersecção a serem considerados para se concluir pela viabilidade da arbitragem relacionada à atividade de tributação. Esse ponto específico será brevemente analisado sem pretensões de esgotar o assunto, na medida em que há vasta e aprofundada doutrina sobre a possibilidade de o Estado, enquanto contratante, solucionar controvérsias por arbitragem.

Como a eficiência é dever da administração pública, optar pelo método de solução de controvérsias mais célere e adequado é obrigação e decorre precipuamente de sua função. $^{208}$

${ }^{207}$ Vale salientar que Martin Shapiro (Who guards the guardians? Judicial control of administration. p. 155159) trata da superioridade técnica de decisões proferidas administrativamente na esfera das agências estatais, inviabilizando uma adequada interferência do judiciário estatal sobre tais processos decisórios.

${ }^{208}$ Nesse sentido, Alexandre Monteiro e Leonardo Castro afirmam que "o poder de instituir arbitragem ou outras medidas alternativas para solução de conflitos no âmbito tributário deixa de ser uma faculdade e, diante do cenário jurídico caótico e instável atual, passa a ser uma necessidade" (Direito Tributário e arbitragem: uma análise da possibilidade e dos óbices ao juízo arbitral em matéria tributária no Brasil, p. 37 $38)$. 
É certo que nem sempre o direito em disputa será passível de solução arbitral, na medida em que há interesses públicos sobre os quais o Estado não poderá dispor. ${ }^{209}$ No entanto, em se tratando de aspecto sobre o qual o Estado pode contratar, não haveria razão para afastar a solução pela via arbitral. ${ }^{210}$

A administração pública, na busca do seu fim precípuo, a saber, bem estar dos administrados e a adequada administração dos bens públicos, deve ser eficiente, ${ }^{211}$ respeitar a moralidade e não poderá jamais se afastar da legalidade. Tais aspectos não são descartados na atividade contratual do Estado e igualmente não os abandona na hipótese de se optar pela solução arbitral das controvérsias que envolvem o Estado, sobretudo diante da celeridade e especialidade do julgamento.

A doutrina chega a recomendar a adoção da arbitragem quando a complexidade da situação e necessidade de agilidade justificarem a escolha de método de solução distinto da judicial estatal. ${ }^{212}$ Por certo não haverá respeito algum ao interesse público a demora e a possibilidade de decisão menos especializada, ainda que proferida pelo juiz estatal, se comparada à celeridade e especialidade da solução arbitral. ${ }^{213}$

209 A doutrina distingue os interesses públicos primários daqueles secundários, sendo estes últimos disponíveis e patrimoniais e, portanto, conflitos que o envolvam são passíveis de solução pela via arbitral.

${ }^{210}$ Esse é o pensamento de Caio Tácito, que salienta que uma vez se tratando de questão com envolvimento de contraprestação financeira do Estado, a solução da controvérsia por arbitragem será cabível (Arbitragem nos litígios administrativos, p. 142.

${ }^{211}$ Sobre a relevância da eficiência administrativa como aspecto a incentivar o uso da arbitragem tributária, vide Lauro da Gama e Souza Jr., Sinal verde para a arbitragem em parcerias público-privadas (a construção de um novo paradigma para os contratos entre o Estado e o investidor privado),p. 20-22. Como conclui o autor, "o princípio da eficiência do agir administrativo insere-se nesse contexto, flexibilizando os meios utilizados pela administração para a realização de suas ações, como contrapartida de um aumento dos controles dos resultados por ela obtidos" (p. 22).

212 "Não só o uso da arbitragem não é defeso aos agentes da Administração, como, antes, é recomendável, posto que privilegia o interesse público”, defende Eros Roberto Grau, Arbitragem e contrato administrativo, p. 15.

Paulo Brancher igualmente advoga pela possibilidade da adoção da arbitragem pelo poder público (in Soluções de controvérsias e as Agências Reguladoras, p. 46).

${ }^{213}$ A doutrina italiana igualmente advoga pela aplicabilidade de mpetodos alternativos de soluçaõ de conflitos no setor público: "Merita inoltre che la tesi delle ADR como espressione della privatizzazione della giustizia non corrisponde a verità nel caso delle procedure che gli ordinamenti giuridici mettono a disposizione degli interessati secondo precisi schemi normativi, disciplinanti le diverse fasi della procedura, il ruolo degli aggiudicatori/conciliatori ed il valores giuridico dell'atto conclusivo della procedura stessa. In tal senso, le ADR non attentano alla disciplina publicista delle forme de tutela, rappresentando di queste solo uma variante non giurisdizionale mirata ad offrire nouve apportunità per gli interessati" (CHITI, Mario, in La forme di resoluzione delle controversie con la pubblica amministrazione alternative alla giurisdizione, p. 6.). 
A jurisprudência, a seu turno, já se encontra consolidada acerca da viabilidade de adoção de arbitragem pelo Estado. Desde advento do famoso Caso Lage ${ }^{214}$ julgado pelo Supremo Tribunal Federal, ocasião na qual foi ressaltado no acórdão não ser possível a interdição do Juízo Arbitral nas causas contra a Fazenda, "o que importaria numa restrição à autonomia contratual do Estado que, como toda a pessoa 'sui juris', pode prevenir o litígio pela via transacional, não se lhe podendo recusar esse direito, pelo menos na sua relação de natureza contratual ou privada, que só estas podem comportar soluções pela via arbitral, dela excluídas aquelas em que o Estado age como Poder Público que não podem ser objeto de transação". ${ }^{215}$

Vale destacar o relatório do ICC (International Court of Arbitration) que destaca que mundialmente o número de arbitragens envolvendo Estados ou entidades públicas representou 9,5\% das arbitragens havidas no ano de 2009, tendo havido solução, sobretudo, de casos que tratam de construção civil. ${ }^{216}$

É importante, no entanto, esclarecer que a adoção da arbitragem pelo poder público necessariamente herdará toda a roupagem atribuída a todo e qualquer ato praticado pela administração pública, na medida em que a legalidade ${ }^{217}$ não pode deixar de ser observada.

${ }^{214}$ Confira-se a ementa do histórico julgado do C. STF:

INCORPORAÇÃO - BENS E DIREITOS DAS EMPRESAS ORGANIZAÇÃO LAGE E DO ESPÓLIO DE HENRIQUE LAGE - JUÍZO ARBITRAL - CLÁUSULA DE IRRECORRIBILIDADE - JUROS DA MORA - CORREÇÃO MONETÁRIA.

1 - Legalidade do Juízo Arbitral, que o nosso Direito sempre admitiu e consagrou, até mesmo nas causas contra a Fazenda. Precedente do Supremo Tribunal Federal.

2 - Legitimidade da cláusula de irrecorribilidade de sentença arbitral, que não ofende a norma constitucional.

3 - Juros de mora concedidos, pelo acórdão agravado, na forma de lei, ou seja, a partir da propositura da ação. Razoável interpretação da situação dos autos e da Lei $n^{\circ} 4.414$, de 1964 .

4 - Correção monetária concedida, pelo Tribunal a quo, a partir da publicação da Lei $n^{\circ} 4.686$, de 21.6.65.Decisão correta.

5 - Agravo de instrumento a que se negou provimento. (...)” (STF. Ag 52.181. Tribunal Pleno. DJ de 13/02/1974).

215 Vale destacar outros julgados oriundos do Superior Tribunal de Justiça que, mais recentemente, igualmente decidiram pela viabilidade de o poder púbico solucionar controvérsias por arbitragem: REsp 904.813, MS 11.308, dentre outros.

${ }^{216}$ ICC International Court of Arbitration Bulletin, vol. 21/1, 2010.

${ }^{217}$ Ao estudar sobre a possibilidade de a administração pública solucionar controvérsias mediante arbitragem, Ada Pellegrini Grinover traz a legalidade como pressuposto e requisito essencial para tanto (Arbitragem e prestação de serviços públicos, p. 67), concluindo, ao final, que "não deve pairar qualquer dúvida sobre a admissibilidade da arbitragem envolvendo a Administração” (p. 73). 


\subsection{Legalidade}

Em tratando a presente investigação de aspecto material de direito tributário, imprescindível analisar a legalidade na seara tributária, com vistas a investigar se a estrita legalidade, prescrita no artigo 150, I, da Constituição Federal, afastaria a arbitrabilidade das controvérsias tributárias. ${ }^{218}$

$\mathrm{Na}$ medida em que discorremos sobre direito tributário, não só a legalidade insculpida no artigo $5^{\circ}$, inc. II da Constituição Federal, nem tampouco a vertente legalidade para a administração pública, cf. artigo 37 da Lei Maior, hão de isoladamente intervir. O constituinte foi deveras cauteloso ao prescrever no artigo 150, I da Lei Maior vertente da legalidade aplicável exclusivamente ao direito tributário, determinando que as pessoas dotadas de competência tributária não podem "exigir ou aumentar tributo sem lei que o estabeleça”.

Sob esse enfoque, as regras do processo tributário devem cuidar de garantir que as determinações acerca do crédito tributário obedeçam à estrita legalidade, sendo inviável, por exemplo, que qualquer solução acerca dos aspectos materiais da regra matriz tributária seja tomada por modalidade processual desprovida de respaldo legal. ${ }^{219}$

Acerca da interferência da legalidade no processo tributário, James Marins esclarece que o processo administrativo fiscal é diretamente dependente da determinação legal e, ademais, que não pode caber esfera de discricionariedade nos atos administrativos de julgamento fiscal. ${ }^{220}$

A roupagem legalista de toda e qualquer regra destinada a regular a solução de controvérsia tributária é, assim, inerente ao sistema tributário brasileiro. Com salienta James Marins, "afigura-se de alto valor lógico o encadeamento no sistema tributário nacional dos princípios do plano material da estrita legalidade e tipicidade com os

\footnotetext{
${ }^{218}$ Importante destacar que a análise acerca do alcance e limites da estrita legalidade tributária terá aplicabilidade na análise da transação que será feita no presente estudo. Muito embora o assunto vá ser pormenorizadamente analisado abaixo (item III.1.4), os aspectos gerais da legalidade somente serão aqui abordados.

${ }^{219}$ Sobre a necessidade de a arbitragem estar prevista em lei, Oswaldo Othon, A transação e a arbitragem... p. 80.

${ }^{220}$ In Direito processual tributário brasileiro, p. 156-157.
} 
princípios do plano formal da legalidade objetiva e da vinculação, que galvanizam a esfera de proteção legal à relação jurídica tributária - estática e dinâmica - e consolidam seu regime de especial segurança constitucional. Nesse altamente coerente sistema de legalidade protege-se a um só tempo a relação jurídica tributária em sua forma, seu conteúdo e sua atuação", 221

Antonio Souza Ribas ${ }^{222}$ analisou a questão justamente pela possibilidade de solução de controvérsia tributária mediante arbitragem, desde que haja previsão legal, sem que com isso reste violada a estrita legalidade.

Heleno Taveira Torres igualmente advoga pela possibilidade de a lei prever a solução arbitral do conflito tributário, na medida em que tal providência esteja vinculada à eficiência e praticabilidade da tributação. ${ }^{223}$

Do que se infere que, havendo autorização e previsão legal ${ }^{224}$, a arbitragem tributária poderá ser adotada pela administração pública como forma de solucionar a controvérsia tributária, a depender da anuência do contribuinte quanto à sua adoção (o que decorre da própria natureza da arbitragem). Em assim sendo, não haverá ofensa a legalidade.

Nessa linha, vale destacar o entendimento acerca da viabilidade do procedimento arbitral desde que respeitada a legalidade, a exemplo do que decidiu a Câmara de Conciliação e Arbitragem (CCAF), criada pela Portaria 1.281/2007, a qual, nos termos

${ }^{221}$ Direito processual tributário brasileiro, p. 157.

${ }^{222}$ In Arbitragem como meio alternativo na solução de controvérsias tributárias. Confira-se: "Como restou demonstrado, a indisponibilidade do crédito tributário e a estrita legalidade não impedem a administração de se submeter à arbitragem, exigindo-se apenas que o legislador possa definir com suficiente precisão os pressupostos e o alcance deste mecanismo de solução de conflitos, distinto do Judiciário, mas àgil e especializado, também neutro e imparcial".

${ }^{223}$ Confira-se: "nada impede que a lei possa qualificar, dentro de limites e no atendimento do interesse coletivo, os melhores critérios para constituição, modificação ou extinção do crédito tributário, inclusive os meios de resolução de conflitos, vinculativamente e com espaço para discricionariedade, no que couber, visando a atender à praticabilidade, economicidade, celeridade e eficiência da Administração Tributária" (in Transação, Transação, arbitragem e conciliação judicial como medidas alternativas para resolução de conflitos entre administração e contribuintes - simplificação e eficiência administrativa, p. 56.).

${ }^{224}$ Nesse sentido, vale transcrever a posição de Heleno Taveira Torres: "com a lei criando condições para que se alcance uma posição de justiça sobre os elementos concretos da situação conflitiva, regula-se o modo adequado para solução do conflito e consequente extinção do crédito tributário sem demoras ou excessos de procedimentos" (in Transação, arbitragem e conciliação judicial como medidas alternativas para resolução de conflitos entre administração e contribuintes - simplificação e eficiência administrativa, p. 50). 
exarados no Parecer AGU/SRG 01/2007, ${ }^{225}$ é competente para solucionar controvérsias jurídicas tributárias existentes entre os órgãos da Administração Federal. ${ }^{226}$

Tratou-se, na ocasião, de solução de controvérsia travada entre o Banco Central do Brasil e a Receita Federal do Brasil acerca da incidência de contribuições previdenciárias sobre pagamentos feitos a profissionais autônomos que prestam serviços ao Programa de Assistência à Saúde de servidores do Banco Central do Brasil.

Consoante destaca-se no Parecer AGU/SRG 01/2007, atendidos os requisitos legais a CCAF poderá, sim, tratar de assuntos tributários, na medida em que o requisito da legalidade terá sido preenchido com o preenchimento de aspectos formais tais como competência e inexistência de vedação em sentido contrário. Como ressalta o parecer, “caem por terra obstáculos, quanto à possibilidade de conciliação em matéria tributária, pautados na suposta infração ao princípio da legalidade, ao se compreender que a advertência jurídica acerca da legalidade estrita, fundamento do direito tributário, resta imaculada com o advento da conciliação. (...) resguarda a seara tributária os atos administrativos praticados e o patrimônio individual da tributação". ${ }^{227}$

Na medida em que as partes não lograram solucionar o conflito em conciliação, houve emissão do Parecer AGU/SRG 01/2008, em linha com a fixação da competência da CCAF para solucionar matéria tributária, decorrente do Parecer AGU/SRG 01/2007228, que em sua ementa prescreve que "a conciliação entre Órgãos elou Entidades da Administração Federal, no âmbito da Advocacia-Geral da União, inclui a matéria de natureza tributária", bem como que "é da competência da Câmara de Conciliação e Arbitragem da Administração Federal - CCAF, integrante da Consultoria-Geral da União, a competência para a conciliação de controvérsias envolvendo a matéria tributária".

Resta, apenas, averiguar se a legislação que autorizará a adoção da arbitragem deve ser complementar.

\footnotetext{
${ }^{225}$ Emitido no processo n. 00407.001676/2007-22.

${ }^{226}$ Uma análise da atuação da CCAF é feita por SILVA, Eduardo da e DALMAS, Samis Bahlis, Câmara de Arbitragem da AGU e modelo arbitral brasileiro: aproximações e distinções, p. 341.

${ }^{227}$ Fls. 5 do referido Parecer.

${ }^{228}$ Emitido no processo n. 00407.001676/2007-22.
} 


\subsubsection{A necessária previsão legal}

Em seu artigo 146, a Constituição Federal determina que a lei complementar deve estabelecer privativamente sobre normas gerais em matéria de legislação tributária ${ }^{229}$ e, a despeito de promulgado como lei ordinária, o Código Tributário Nacional de 1966, lei 5.172, foi recepcionado ${ }^{230}$ com o status de lei complementar pela nova ordem constitucional.

O Código Tributário Nacional trata das normas gerais em matéria tributária, tais como aspectos da competência tributária, os tributos em espécie (impostos, taxas e contribuição de melhoria), a distribuição de receitas tributárias, a obrigação tributária, o crédito tributário e a administração tributária. O CTN não trata, como se vê e à exceção de algumas normas esparsas que podem ser pinceladas numa leitura atenta do codex, do processo tributário nem tampouco das formas de solução das controvérsias tributárias.

Somando-se ao fato de inexistir na lei complementar regras sobre o processo tributário, constata-se que (i) o Código de Processo Civil, lei ordinária, regula as ações judiciais tributárias; (ii) a Execução Fiscal é regulada pela Lei n. 6.830/80, ordinária; (iii) o processo administrativo fiscal federal é delineado pelo Decreto 70.235/1972. Além disso, a Constituição Federal é expressa ao determinar que somente a lei federal ordinária pode

${ }^{229}$ Confira-se inteiro teor do dispositivo:

Art. 146. Cabe à lei complementar:

I - dispor sobre conflitos de competência, em matéria tributária, entre a União, os Estados, o Distrito Federal e os Municípios;

II - regular as limitações constitucionais ao poder de tributar;

III - estabelecer normas gerais em matéria de legislação tributária, especialmente sobre:

a) definição de tributos e de suas espécies, bem como, em relação aos impostos discriminados nesta Constituição, a dos respectivos fatos geradores, bases de cálculo e contribuintes;

b) obrigação, lançamento, crédito, prescrição e decadência tributários;

c) adequado tratamento tributário ao ato cooperativo praticado pelas sociedades cooperativas.

d) definição de tratamento diferenciado e favorecido para as microempresas e para as empresas de pequeno porte, inclusive regimes especiais ou simplificados no caso do imposto previsto no art. 155,

II, das contribuições previstas no art. 195, I e $\$ \$ 12$ e 13, e da contribuição a que se refere o art. $239^{\prime \prime}$.

${ }^{230}$ O CTN, promulgado como lei ordinária, foi recepcionado pela Carta Constitucional de 1988 com status de lei complementar nos termos do artigo 34, parágrafo $5^{\circ}$ do ADCT. Esse é o entendimento reiterado do STF (a exemplo do seguinte julgado: RE 238358 AgR, Relator(a): Min. JOAQUIM BARBOSA, Julgamento: 05/04/2011). 
dispor sobre normas processuais (artigo 22, I da Constituição Federal), ${ }^{231}$ havendo exceções pontuais de aspectos privativamente regulados por lei complementar.

Diante das constatações acima, conclui-se que no atual sistema vigente, não é necessário que formas de solução de controvérsias tributárias venham previstas em lei complementar para ter validade, na medida em que o processo tributário é comumente tratado em legislação ordinária.

\subsubsection{Investigando a necessidade de edição de lei com status complementar}

Não obstante a constatação de que as regras que norteiam o processo tributário, à exceção de pontuais apontamentos contidos no CTN, podem e são veiculadas por legislação meramente ordinária, resta investigar se a possibilidade de a solução do conflito ser tomada em processo arbitral depende ou não de autorização em lei complementar. Dito de outro modo, passemos a averiguar se seria ou não necessária a edição de lei complementar para viabilizar a arbitragem tributária.

As hipóteses de extinção do crédito tributário são taxativas e se encontram insculpidas no CTN, lei recepcionada pela Constituição Federal de 1988 com status de complementar; desse modo, caso venha a ser possível que o crédito tributário regularmente constituído pelo fisco seja desconstituído por sentença arbitral, tal hipótese deverá constar expressamente no CTN, prescindindo, portanto, da edição de legislação com status complementar. $^{232}$

Seria viável a adoção de arbitragem para solução de controvérsias tributárias sem possibilidade de a solução ser instrumento hábil a extinguir o crédito tributário? Como visto acima, ${ }^{233}$ a doutrina que se dedicou ao estudo da arbitragem tributária não é unânime

\footnotetext{
${ }^{231}$ Dinamarco, in Instituições de Direito Processual Civil, vol. I, p. 76-78, traz as principais leis federais ordinárias que tratam do processo civil e, quanto a aspectos exclusivamente regulador por lei complementar, o autor menciona a Lei Orgânica da Magistratura, o Estatuto do Ministério Público da União Federal, a Lei Orgânica Nacional da Advocacia-Geral da União, a Lei Orgânica da Defensoria Pública, dentre outras (p. 79).

${ }^{232}$ Sobre a extinção do crédito tributário e a arbitragem, vide item II.2.10 infra.

${ }^{233}$ Item II.2.2.
} 
acerca da possibilidade de a arbitragem se instaurar preventivamente à existência do débito tributário, ou seja, arbitragem preventiva. ${ }^{234}$

Partindo da premissa de que a solução da controvérsia mediante arbitragem deve ser meio hábil para desconstituir o objeto em litígio, vislumbra-se que não seria aproveitável a adoção da arbitragem cuja sentença não tenha o condão de extinguir a obrigação tributária.

Tanto é assim que o mencionado artigo 156 do $\mathrm{CTN}^{235}$ aponta como formas de extinção do crédito tributário tanto a decisão administrativa não mais passível de recursos quanto a decisão judicial transitada em julgado (incisos IX e X, respectivamente).

Haveria relevância na instituição da arbitragem apenas e tão-somente voltada a solucionar controvérsias tributárias anteriores à constituição do crédito tributário? Nesse caso, a decisão arbitral teria o condão de vincular ulterior discussão judicial ou administrativa acerca de eventual crédito tributário que venha a surgir em decorrência da controvérsia solucionada mediante julgamento arbitral?

Não haveria, a nosso ver, sequer utilidade na adoção de método voltado a prover solução a controvérsia tributária que não tenha o condão de extinguir o crédito tributário ou mesmo dispor sobre a suspensão da sua exigibilidade, na medida em que para o desenrolar das atividades dos contribuintes é crucial que a discussão tributária não obste a emissão de certidão negativa de débitos.

O artigo 151 do CTN prevê que a liminar em mandado de segurança ou em qualquer outra medida judicial, a discussão administrativa e a concessão de suspensão dos efeitos da tutela são condições suspensivas da exigibilidade do crédito tributário, ao que se equipara, para fins de emissão de certidões negativas, a penhora regularmente efetuada em ação executiva fiscal, ${ }^{236}$ fica clara a utilidade dos processos judicial e administrativo. Tal se verifica, também, com relação à consulta fiscal, na medida em que desde sua

\footnotetext{
${ }^{234}$ Sobre o assunto, vide abaixo II.2.2.

${ }^{235}$ Importa salientar que o Projeto de Lei Complementar 469/2009 inseriu, dentre as hipóteses do artigo e 156 do CTN, o laudo arbitral.

${ }^{236} \mathrm{Ou}$ em medida cautelar antecipatória de garantia, cf. I.3.2 acima.
} 
apresentação até 30 dias após a ciência da decisão administrativa, o contribuinte, por determinação legal, ${ }^{237}$ está protegido de atos constritivos por parte da administração tributária federal que acarretem a aplicação de penalidades moratórias.

A adoção de qualquer método de solução de controvérsias que não tenha respaldo legal necessário a conferir autoridade para extinguir ou suspender o crédito tributário, ou mesmo amparar o contribuinte de atos constritivos até que a solução seja definitivamente tomada, não será, portanto, eficaz. E para que a sentença arbitral seja dotada de tais predicados, imprescindível a edição de legislação com status complementar.

Importa, outrossim, destacar a importância de que a arbitragem, se possível aos contribuintes, interrompa o curso do prazo prescricional relativo à cobrança do crédito tributário, o que exige alteração do texto do artigo 174 do CTN. ${ }^{238}$

Outro aspecto a ser considerado refere-se à possibilidade de a sentença arbitral reconhecer o pagamento indevido feito pelo contribuinte e, nesse sentido, constituir um crédito em favor do sujeito passivo da relação jurídica tributária. O artigo 165 do CTN prevê que a decisão judicial passada em julgado poderá reconhecer o pagamento indevido do tributo, não atribuindo tal aspecto sequer à decisão administrativa. Assim, para que a arbitragem possa igualmente constituir crédito em favor do contribuinte, ${ }^{239}$ necessária será a reforma legislativa do CTN mediante edição de lei complementar.

Nos parece, enfim, que a instituição da arbitragem para solucionar apenas litígios preventivos à existência do crédito tributário não surtiria os esperados efeitos de proporcionar método de solução mais ágil, especializado e flexível em se tratando de assuntos tributários.

\footnotetext{
${ }^{237}$ Cf. artigo 161, parágrafo $2^{\circ}$ do CTN.

${ }^{238}$ Tal alteração se encontra prevista no projeto de lei complementar 469/2009.

${ }^{239}$ Desenvolvendo tal hipótese, vide II.2.9 abaixo.
} 
Assim, conclui-se pela necessidade de edição de lei complementar dispondo sobre a possibilidade de (i) a sentença arbitral extinguir o crédito tributário, ${ }^{240}$ (ii) o processo arbitral suspender a exigibilidade do crédito tributário ou mesmo (iii) haver interrupção do prazo prescricional com a instauração do processo arbitral, sob pena de não ser adequada adoção do método de tal natureza para solução para controvérsias.

Nessa mesma linha é o ensinamento de Heleno Taveira Torres, ${ }^{241}$ para quem a instituição de arbitragem como forma hábil a solucionar controvérsia tributária prescinde da edição de lei complementar. O Professor ressalta que a norma geral a tratar da arbitragem deve ser editada por Lei Complementar, sob pena de ofensa ao artigo 146 da Constituição Federal mas, de outro lado, a (i) lei formal, que tratará do procedimento e forma de escolha dos árbitros, composição do tribunal arbitral, efeitos da decisão e do laudo arbitral; e a (ii) lei material, com contornos das controvérsias que poderiam ser levadas à solução por arbitragem, poderão ser meramente ordinárias.

\subsection{Autonomia da vontade}

A autonomia da vontade das partes é aspecto intrínseco da arbitragem na medida em que a solução arbitral do conflito somente será adotada se as partes assim acordarem, ${ }^{242}$ o que podem fazer livremente e tendo sempre garantia da inafastabilidade da jurisdição estatal, na medida em que todo e qualquer conflito pode ser levado ao Judiciário. Ou seja, as partes, ao optarem pela arbitragem, optam por não obter solução judicial ao conflito mas ao mesmo tempo sabem que, nos casos necessários, o Poder Judiciário poderá socorrê-las.

A opção pela solução da controvérsia por arbitragem representa, assim, manifestação da autonomia da vontade refletida no texto do artigo $2^{\circ}$ da Lei da Arbitragem e, em se tratando de direito tributário, tal manifestação deverá encontrar limites e condições na lei, na medida em que não se pode afastar a legalidade nem tampouco a tipicidade tributárias.

\footnotetext{
${ }^{240}$ Importa destacar que nem sempre a sentença arbitral extinguirá o crédito tributário, na medida em que tal prerrogativa ficará a cargo do pagamento, compensação ou outra forma já elencada no CTN. Vide, sobre o assunto, II.2.9 abaixo.

${ }^{241}$ In Transação, arbitragem e conciliação judicial como medidas alternativas para resolução de conflitos entre administração e contribuintes - simplificação e eficiência administrativa, p. 59.

${ }^{242}$ Carlos Alberto Carmona salienta que "ponto fundamental da arbitragem é a liberdade dos contratantes ao estabelecer o modo pelo qual seu litígio será resolvido” (Arbitragem e processo, p. 75).
} 
José Casalta Nabais ${ }^{243}$ traz uma comparação do desenvolvimento da arbitragem tributária brasileira ao fenômeno verificado quando o Estado passou a ser contratante, justamente por se ser a arbitragem, como define o autor, uma "manifestação da abertura do contrato". 244

A arbitragem como método de solução de controvérsias, deve observar o devido processo legal, o contraditório e a ampla defesa, igualdade das partes, imparcialidade dos árbitros e seu livre convencimento (consoante previsão expressa do artigo 21, parágrafo $2^{\circ}$ da Lei da Arbitragem), sob pena de haver legitimidade para questionamento judicial do quanto venha a ser decidido pelo tribunal arbitral.

Quanto à necessária autonomia da vontade das partes como pressuposto necessário à submissão de determinado conflito à solução arbitral, igualmente se estará vinculada aos princípios constitucionais, na medida em que não se pode afastá-los de qualquer forma de solução adequada de controvérsias. ${ }^{245}$

Carlos Alberto de Salles salienta, no entanto, que em determinadas situações nas quais uma das partes é claramente hipossuficiente, a autonomia da vontade pode não prevalecer e, nesses casos, a solução arbitral do conflito não seria adequada nem tampouco recomendável. ${ }^{246}$

Em se tratando de controvérsia tributária, parece razoável supor que, via de regra, o contribuinte estará em situação hipossuficiente se comparado ao fisco, que possui todo o aparato da máquina estatal, além da indelegável competência tributária.

\footnotetext{
${ }^{243}$ In Reflexão sobre a introdução da arbitragem tributária, p. 31 e seguintes.

${ }^{244}$ Reflexão sobre a introdução da arbitragem tributária, p. 31.

245 Paulo Osternack Amaral conclui que "muito embora a autonomia das partes seja ampla na arbitragem, ela encontra limite nos princípios constitucionais, especialmente na observância do princípio constitucional do devido processo legal" (Arbitragem e administração pública - aspectos processuais, medidas de urgência e instrumentos, p. 52).

${ }^{246} \mathrm{O}$ autor trata das questões trabalhistas e de consumo, salientando que nos Estados Unidos da América é comum a solução arbitral de questões relativas a consumo, na qual o consumidor está em clara posição de hipossuficiência, considerando plausível a decretação da inconstitucionalidade do acordo instituidor de arbitragem em tais situações (Arbitragem em contratos administrativos, p. 36-37).
} 
Permite-se concluir, desse modo, que nem sempre a arbitragem poderá ser adotada como manifestação exclusiva da autonomia da vontade, o que se infere da própria necessidade de previsão legal para instauração da solução arbitral das controvérsias. ${ }^{247}$

De outro lado, não parece que inviabilizar a solução arbitral das controvérsias tributárias seria o mais adequado em razão de tal possibilidade nem sempre decorrer de manifestação da autonomia da vontade.

Como a seara tributária é sui generis e ambas as partes compõem um vínculo jurídico independentemente de vontade - na medida em que o Estado deve exercer a competência tributária e não pode abrir mão da arrecadação; a seu turno, o contribuinte, ao praticar o fato jurídico relevante para fins de tributação, não escolhe estar sujeito ou não à tributação, sendo-lhe tal imposta por decorrência legal - não se mostra necessário que a solução da controvérsia tributária dependa exclusivamente da autonomia da vontade.

Cite-se um exemplo prático fictício: determinado trabalhador, como remuneração de seu ofício, recebe rendimentos tributários decorrentes de trabalho assalariado. No decorrer do ano-exercício, a fonte pagadora (empregador) retém mensalmente o Imposto sobre a Renda Retido na Fonte, nos termos da legislação tributária em vigor. Ao final do exercício, o trabalhador prepara sua declaração de ajuste e verifica que, a despeito de toda a retenção havida no decorrer do ano, há Imposto sobre a Renda adicional a pagar.

O trabalhador, involuntariamente sujeito passivo da relação jurídico tributária, passa a ter a obrigação de realizar pagamento do montante apurado a título de imposto sobre a renda. Não o fazendo, estará sujeito aos atos de cobrança e fiscalização por parte do fisco.

Sob perspectiva oposta, a fiscalização tributária recebe informações tanto da fonte pagadora (empregador) quanto do trabalhador acerca da renda auferida e, nos termos da lei, apura a insuficiência do imposto sobre a renda antecipadamente retido na fonte pela fonte pagadora. Involuntariamente, haverá direito, legitimidade e viabilidade jurídica de

${ }^{247}$ Infra, II.1.5. 
cobrança do saldo em aberto do imposto. Caso haja pagamento pelo trabalhador, não haverá controvérsia acerca do valor devido e o crédito tributário estará extinto.

De outro lado, caso o trabalhador não efetue o pagamento do imposto, involuntariamente a fisscalização deverá lançar e cobrar o crédito tributário, na medida em que se trata de atividade vinculada consoante previsão do artigo $3^{\circ}$ do CTN. Trata-se, assim, de dever indisponível de cobrar o débito.

Suponha, então, que o trabalhador não efetuou o pagamento do imposto por não concordar com os cálculos que resultaram na diferença a pagar. A seu turno, a fiscalização, justamente por ser responsável pelo cálculo, ${ }^{248}$ tem o dever de defender o acerto do valor remanescente apurado e cobrá-lo. Imaginemos que haja, então, lei prevendo que em se tratando de controvérsia quanto ao cálculo do imposto sobre a renda revido por pessoa física quando da elaboração da declaração de ajuste, nos termos e condições que estabeleça, o contribuinte poderá optar por buscar, perante a administração pública, solução arbitral do conflito.

Haveria impedimento de as partes partirem para uma solução arbitral para apuração do valor devido tão-somente em razão da inexistência de manifestação puramente decorrente da autonomia da vontade para sua instauração?

Muito embora, aparentemente, o contribuinte tenha optado, voluntariamente, por aderir à solução arbitral do conflito, ele não escolheu se tornar sujeito passivo da relação jurídico tributária.

De outro lado, a administração poderá vincular-se às possibilidades de instauração da arbitragem prevista na lei, mediante adesão do contribuinte, sem que tenha havido expressa manifestação de vontade nesse sentido.

Não parece que tal mitigação da autonomia da vontade seja suficiente a inviabilizar a solução arbitral no caso aqui exemplificado. Tal particularidade decorre da própria natureza da relação jurídico-tributária e coloca as partes em posição claramente distinta,

${ }^{248}$ Quer pelo cálculo exato do valor devido, quer pela disponibilização do sistema que efetue tal conta. 
mas não pode afastar a adoção de método que entendam mais vantajoso para solução da controvérsia em que involuntariamente se envolveram. Assim, a despeito de haver certa mitigação da autonomia da vontade necessária à submissão do conflito tributário à solução arbitral, não se afasta a validade e utilidade do procedimento no caso investigado.

\subsection{Vantagens da arbitragem na seara tributária}

Diante das reflexões acima, conclui-se pela arbitrabilidade das controvérsias tributárias na medida em que os requisitos legais de disponibilidade e patrimonialidade se encontram presentes e, outrossim, as nuances da controvérsia tributária não afastam a solução privada do conflito na medida em que (i) objetiva e subjetivamente há viabilidade de solução arbitral do conflito, mormente diante do inequívoco caráter patrimonial do objeto da relação jurídico tributária; (ii) ao optar por tal solução o fisco não estará renunciando ao crédito tributário, mas apenas submetendo a controvérsia a solução privada em detrimento da solução judicial estatal; (iii) a legalidade estrita trará os limites e situações às quais a solução arbitral poderá aplicar-se, sendo certo que há aspectos a serem tratados por legislação complementar sob pena de prejuízo da efetividade do procedimento; (iv) o fato de os sujeitos envolvidos na relação jurídica tributária não ali estarem exclusivamente em decorrência de sua vontade não afasta a necessária manifestação da autonomia da vontade para submissão da solução arbitral; e, ademais, (v) mesmo em se tratando de causa tributária, vislumbra-se possibilidade de o fisco renunciar à jurisdição estatal.

A norma portuguesa ${ }^{249}$ que instituiu a arbitragem tributária salienta a necessidade e cabimento do procedimento em razão de três objetivos principais: eficácia da tutela dos direitos envolvidos, celeridade e redução dos casos pendentes de julgamento perante os tribunais judiciais e administrativos tributários.

Resta, nesse passo, analisar se a solução arbitral traria vantagens aos sujeitos envolvidos na controvérsia tributária ${ }^{250}$. Desde a antiguidade, ${ }^{251}$ as partes envolvidas em

\footnotetext{
${ }^{249}$ Decreto-Lei n. 10, de 20 de janeiro de 2011.

${ }^{250}$ Como salienta Carlos Alberto de Sales, não se trata de uma análise arbitragem VS Poder Judiciário na medida em que diante da especialidade da controvérsia tributária, a análise a ser feita deve considerar os valores centrais da arbitragem vis a vis a realidade das lides tributárias (Arbitragem em contratos administrativos, p.29-32).
} 
conflito buscam formas de solução que sejam ágeis, tecnicamente hábeis e proporcionem uma solução justa, sendo certo que mesmo sem ter certeza quanto à prevalência de sua posição, partes em conflitos necessitam de tratamento adequado e de decisão que lhes seja imposta Não seria razoável que o poder público buscasse forma distinta de solução.

Justamente nesse sentido é que Diogo Leite de Campos $^{252}$ defendeu a eminente necessidade de se regulamentar, em Portugal, a arbitragem tributária na medida em que os anseios dos cidadãos e a nova ordem assim exigem, pois a celeridade e especialidade da decisão arbitral justificam sua instituição também em matéria fiscal. Interessante notar que, hodiernamente, já há lei que trata da arbitragem no país ibérico. ${ }^{253}$

A doutrina ressalta dentre as vantagens da arbitragem a celeridade, ${ }^{254}$ a preponderância da autonomia da vontade (na medida em que as partes são livres para escolha dos árbitros e da legislação aplicável quer no âmbito material, quer no processual), ${ }^{255}$ a especialidade e neutralidade dos árbitros e confidencialidade. Tais vantagens, por certo, amoldam-se perfeitamente aos anseios da realidade das soluções de controvérsias tributárias.

A celeridade é aspecto particularmente interessante em se tratando de controvérsia tributária relativa a aspecto inerente a relação continuativa das partes envolvidas. Isso porque, por vezes, o contribuinte não sabe como interpretar as normas e, nesses casos, há dúvida sobre os procedimentos que serão adotados para fins de tributação. Por exemplo, o contribuinte pode não saber se determinado insumo, devido a suas características peculiares, pode ser considerado como totalmente consumido no processo produtivo para

\footnotetext{
251 "Na mais remota antiguidade, a humanidade sempre buscou caminhos que não fossem morosos ou serpenteados de fórmulas rebuscadas, visto que os negócios, sejam civis, sejam comerciais, exigem respostas rápidas, sob pena de, quando solucionados, perderem o objeto e ficarem desprovidos de eficácia, com prejuizos incalculáveis para as partes interessadas. Isto se aplica também à arbitragem no direito público" (SZKLAROWSKY, Leon Frejda. "A arbitragem - uma visão crítica”, p. 3).

${ }^{252}$ In A arbitragem em direito tributário português e o estado-dos-cidadãos, p. 149.

${ }^{253}$ Conforme Decreto-Lei 10/2011.

${ }^{254}$ Selma Lemes relaciona a celeridade à especialidade dos árbitros, na medida em que tal atributo acaba por agilizar o julgamento da controvérsia (Arbitragem na administração pública..., p. 175-176).

${ }^{255}$ Nesse sentido, Paulo Osternack Amaral afirma que "sem dúvida, o principal atrativo da arbitragem consiste na ampla autonomia da vontade que permeia esse método de solução de controvérsias. Como se verá adiante, todas as vantagens que a arbitragem assume em relação ao processo estatal derivam da liberdade conferida às partes, não só em relação à escolha dos árbitros e da legislação (material e procedimental) aplicável, mas também no que concerne ao poder do árbitro de flexibilizar a condução do procedimento" (Arbitragem e administração pública - aspectos processuais, medidas de urgência e instrumentos, p. 35).
} 
fins de creditamento de ICMS. Com a decisão arbitral mais técnica e célere sobre o assunto, a postura de acordo com o quanto decidido poderá ser adotada num curto período de tempo e a adoção de procedimento dúbio não delongará.

José Luís Esquível ${ }^{256}$ aponta como vantagens da arbitragem envolvendo a administração pública a confidencialidade, qualidade técnica do julgamento, neutralidade do julgador (árbitro) e, ainda, a equiparação da sentença arbitral àquela produzida pelo Judiciário em termos de exequibilidade.

Antonio Souza Ribas ${ }^{257}$ trata também da melhora da relação fisco-contribuinte na medida em que no processo arbitral a participação dos envolvidos é mais representativa, na medida em que além da opção voluntária pelo método de solução, a arbitragem permite mais diálogo em todo o decorrer do julgamento.

Um aspecto a ser avaliado com cautela em se tratando de solução arbitral, no entanto, são os custos envolvidos.

Mais especificamente sobre a arbitragem tributária, José Casalta Nabais ${ }^{258}$ salienta que somente se aproveitarão da sua celeridade aqueles contribuintes que possuírem recursos suficientes a arcar com o julgamento da controvérsia por arbitragem, dados os custos razoavelmente elevados. ${ }^{259}$

Paulo Osternack Amaral ressalta que as partes devem ter cautela na opção pela solução da controvérsia pela arbitragem, pois os custos relacionados podem não compensar, a depender da natureza, valor envolvido e complexidade da controvérsia. ${ }^{260}$

\footnotetext{
${ }^{256}$ In Os contratos administrativos e a arbitragem. p. 77-78.

${ }^{257}$ In RIBAS, Antonio Souza. Arbitragem como meio alternativo na solução de controvérsias tributárias, p. 223.

${ }^{258}$ In Reflexão sobre a introdução da arbitragem tributária, p. 39

${ }^{259} \mathrm{O}$ autor questiona se a arbitragem seria realmente mais barata se comparada à solução adjudicada dos conflitos. Ao concluir que a arbitragem seria mais cara do que a solução pela justiça comum, o autor ressalta que não seria o caso de afastar a viabilidade da solução do conflito por arbitragem mas. Apenas chama a atenção para que a análise da relação custo-benefício da adoção da arbitragem seja realizada com a devida cautela.

${ }^{260}$ Arbitragem e administração pública - aspectos processuais, medidas de urgência e instrumentos, p. 5152.
} 
De fato, há controvérsias tributárias que não justificariam solução arbitral na medida em que além do valor envolvido não ser representativo, não necessariamente se tratará de questão cuja solução produzirá efeitos futuros e permanentes. Por exemplo, tratando-se de débito fiscal decorrente de divergência de cálculos, não há continuidade na relação entre as partes que possa, a depender do montante envolvido, justificar o custeio da solução arbitral.

De outro lado, há situações em que, ainda que o valor envolvido não seja extremamente relevante, a controvérsia jurídica se perpetuará no tempo e, desse modo, a relação continuada entre as partes justifica uma decisão mais técnica, na medida em que períodos futuros serão alcançados pelo resultado. Tal ocorre, por exemplo, em dúvida quanto à interpretação da lei: a solução servirá para fatos passados, presentes e futuros que sejam representativos da subsunção do fato hipotético previsto na norma.

Vale, ademais, destacar que a solução arbitral do conflito não representa qualquer vantagem ao contribuinte envolvido na medida em que, tal como na solução judicial, a decisão será exarada por terceiro imparcial não envolvido no conflito e, desse modo, não haverá prevalência de um ou outro ponto de vista em discussão. As vantagens são aquelas decorrentes do método escolhido, como especialidade do julgamento e celeridade, mas não representam qualquer favor fiscal ao contribuinte envolvido. ${ }^{261}$

261 “arbitragem jamais pode ser considerada como 'um beneficio' ao contribuinte, na medida em que um terceiro, imparcial, decidirá com base em fatos e argumentos jurídicos, uma controvérsia emergida de uma relação jurídica, não havendo qualquer benefício (na acepção de vantagem unilateral) para qualquer das partes. É evidente que existem vantagens, tais como a celeridade, tecnicidade e, por vezes, inclusive a redução de custos com a decisão arbitral, mas tais fatores servem tanto para o Fisco como para o contribuinte, jamais podendo ser entendidas como benefícios fiscais tais como anistia, remissão ou isenção tributária”. Essa é a posição de Alexandre Monteiro e Leonardo Castro, in Direito Tributário e arbitragem: uma análise da possibilidade e dos óbices ao juízo arbitral em matéria tributária no Brasil, p. 35. 


\section{CAPÍTULO 2 - ASPECTOS PROCESSUAIS NA ARBITRAGEM}

Diante da conclusão pela viabilidade de se submeter questões tributárias a solução arbitral, na medida em que o crédito tributário, finalidade precípua e objeto de interesse das controvérsias tributárias, é dotado de arbitrabilidade, passa-se enfim à análise específica dos aspectos processuais da arbitragem tributária, na medida em que, diante da particularidade do objeto e das consequentemente necessárias adaptações ao procedimento, se faz necessária uma análise cautelosa das nuances que poderão advir.

Isso não significa, no entanto, que a lei de arbitragem ${ }^{262}$ não será a principal fonte de consulta para se verificar os aspectos processuais da arbitragem tributária, que ora se cogita. De fato, por se tratar a tributação de direito do Estado, cuja competência é indelegavemente exercida pelas pessoas jurídicas de direito público, ${ }^{263}$ torna-se necessário avaliar os diversos aspectos processuais da arbitragem, como forma de adaptá-los, restringi-los ou até mesmo mitigá-los do procedimento aqui delineado.

Toda e qualquer análise, no entanto, não poderá se desvencilhar dos princípios $^{264}$ processuais constitucionais aplicáveis a toda e qualquer forma de solução de conflito, sob pena de acarretar na inviabilidade da decisão proferida. Referimo-nos ao contraditório, devido processo legal, ampla defesa, publicidade, celeridade e, no caso específico da

\footnotetext{
${ }^{262}$ A lei de arbitragem de 1996 quebrou paradigmas e foi responsável pela viabilidade de ampla divulgação e adoção do procedimento arbitral no Brasil. O Supremo Tribunal Federal, quando do histórico julgamento que consolidou a constitucionalidade da mencionada lei, conferiu segurança àqueles que optam por solucionar seus conflitos mediante arbitragem.

SZKLAROWSKY, Leon Fredja, faz uma análise crítica e histórica da lei de arbitragem in "A arbitragem uma visão crítica", p. 203.

Marcos Gomes da Costa (in Tutela de urgência e processo arbitral) trata do histórico da arbitragem, buscando nas origens a necessidade encontrada nos primórdios da civilização, antes mesmo de a figura do Estado com seu poder de coerção ser presente, de que um terceiro imparcial fosse responsável por solucionar os conflitos em que as partes se envolviam, até que na Grécia antiga tenha surgido uma das primeiras figuras do árbitro oficial. Ou seja, a adoção da arbitragem para solucionar os conflitos hodiernamente representa muito mais um retorno às origens do que um avanço - a despeito de justamente os mais tradicionalistas terem certa dificuldade em aceitar o instituto.

${ }^{263}$ Nos termos e limites prescritos nos artigos 153, 155 e 156 da Constituição Federal de 1988.

${ }^{264}$ Selma Lemes faz uma análise dos princípios que permeiam a arbitragem, ressaltando a autonomia da vontade, a boa-fé, tutela jurisdicional, devido processo legal, contraditório, igualdade das partes, imparcialidade do árbitro e de seu livre convencimento, autonomia da cláusula compromissória, acesso ao judiciário (in Princípios e origens da lei de arbitragem, p. 32-35.
} 
arbitragem tributária, legalidade, ${ }^{265}$ sem prejuízo, por certo, dos princípios elencados no artigo 21 da Lei da Arbitragem.

\subsection{Notas sobre procedimento arbitral tributário brasileiro, datado do Império}

Antes de adentrar nos aspectos processuais da arbitragem que ora se cogita, cumpre trazer alguns aspectos do procedimento que já existiu nos tempos do império, instituído pelo Decreto No. 2.467 de 19 de setembro de 1860 e consolidava o Regulamento das Alfândegas e Mesas de Rendas.

O regulamento em questão tratava de procedimentos de comércio exterior e em diversos momentos possibilitava que o contribuinte optasse pela solução por arbitramento, ${ }^{266}$ trazendo procedimento específico para tanto.

${ }^{265}$ Cf. acima concluído, diante da estrita legalidade tributária não há como qualquer método de solução de controvérsias se desvincular de expressa autorização legal (supra, II.1.5).

${ }^{266}$ Vale transcrever, por serem poucos, os principais dispositivos que tratam do processo de arbitramento (cf. redação original):

Art. 577. O processo de arbitramento, nos casos marcados pelo presente Regulamento, e salvas as disposições do Cap. $5^{\circ}$ do Tit. $3^{\circ}$ e Cap. $3^{\circ}$ do Tit. $8^{\circ}$, se regulará pelas seguintes:

$\S 1^{\circ}$ O Ministro da Fazenda na Côrte, e os Inspectores das Thesourarias de Fazenda nas Províncias escolherão d'entre as differentes classes dos Negociantes, Empregados, e pessoas profissionaes em cada hum ramo de industria, domiciliadas no lugar em que funccionar a respectiva Repartição Fiscal, que julgar mais idoneos para servirem de peritos ou practicos nas questões a que se referem os arts $559 \S 2^{\circ}$, 566 e $570 \S 5^{\circ}$ A relação destes peritos assim escolhidos será publicada, e revista no fim de cada semestre, e sua leitura sempre franqueada ás partes.

$\S 2^{\circ}$ Verificado o caso de arbitramento, a parte escolherá d'entre as pessoas incluidas na lista de que trata o paragrapho antecedente dous arbitros, e manifestará por escripto ao Chefe da Repartição a sua definitiva escolha. Por sua vez o Inspector da Alfandega, ou Administrador da Mesa de Rendas escolherá do mesmo modo os dous arbitros da Fazenda Publica, e de accordo, com a parte hum quinto, e se esta se recusar a isso á sua revelia será o quinto arbitro designado pelo mesmo Inspector, ou Administrador, que marcará o dia em que elles se devem reunir; no caso porém de não haver accordo sobre o $5^{\circ}$ arbitro será este designado pela sorte d'entre seis nomes escolhidos da lista dos arbitros, sendo tres pelo Chefe da Repartição, e outros tantos pela parte.

$\S 3^{\circ}$ Reunidos os quatro arbitros sob a presidencia do Chefe da Repartição, feita por este a exposição do facto, e ouvida a parte, procederão aos exames e indagações que julgarem convenientes, e no mesmo acto darão seu parecer por escripto, que será por todos assignado; não podendo retirar-se antes de concluido o julgamento e sua assignatura. E o que o contrario fizer será multado pelo Chefe da Repartição em $50 \$$ até 200\$, lavrando-se disto hum termo especial. Não comparecendo todos os arbitros no dia e hora marcados, o Inspector designará outro dia e hora; $e$ se ainda se verificar neste ultimo caso falta, os arbitros presentes, qualquer que seja o seu numero, darão logo sua decisão; no caso, porém, da falta ser proveniente de fallecimento, ou de mudança de domicilio de algum dos arbitros, se procederá á substituição deste na fórma do $\S 2^{\circ}$

$\S 4^{\circ}$ A decisão se regulará pela maioria dos votos; quando porém houver empate decidi-lo-ha o quinto arbitro que houver sido nomeado a apraziniento da parte e do Chefe da Repartição, ou por este á revelia daquella.

$\S 5^{\circ}$ No caso da parte se louvar nos arbitros nomeados pelo Inspector da Alfandega, ou Administrador da Mesa de Rendas, a decisão destes será reputada decisão arbitral para todos os effeitos marcados neste Regulamento. No caso de empate entre estes, se escolherá hum terceiro 
O processo de arbitramento ${ }^{267}$ se iniciava com a publicação semestral de uma lista de técnicos ${ }^{268}$ de cada "ramo de indústria", domiciliados no local das respectivas repartições fiscais, nomeados pelo Ministro da Fazenda ou Inspetores das Tesourarias. Ao optar pela solução por arbitramento, a parte escolheria da lista dois árbitros e, após, a fazenda pública elegeria unilateralmente outros dois deles e ambos contribuinte e fazenda escolheriam um quinto árbitro, em comum acordo.

Eram, então, designado dia e hora para comparecimento dos árbitros que, após análise do caso, proferiam seu parecer por escrito e, em caso de empate, o quinto árbitro seria chamado para o voto de minerva. Interessante destacar que a própria norma estabelecia que o quinto árbitro somente poderia votar de acordo com um dos votos já existentes, não podendo proferir um terceiro voto distinto dos demais.

A decisão arbitral era irrecorrível, à exceção de decisão tomada por entidade incompetente, com excesso de poder, violação de lei ou de forma essencial, ${ }^{269}$ podendo parte, se preferir, reexportar as mercadorias para evitar o ônus fiscal que tenha sido definido por arbitramento.

arbitro, na fórma estabelecida no $\$ 2^{\circ}$, para a nomeação do quinto. Este quinto arbitro será sempre obrigado a concordar com hum dos laudos empatados.

Art. 578. Os peritos ou practicos do Commercio, antes de procederem ao exame do objecto questionado, e de darem o seu parecer, prestarão juramento nas mãos do Chefe da Repartição, conforme a religião que professarem, de o fazerem segundo suas consciencias, sem dolo, nem malicia.

Art. 579. De taes decisões não haverá recurso algum, excepto o do art. 764, $\S 2^{\circ}$; mas todos os papeis a ellas relativos serão guardados no archivo, e a parte poderá reexportar, no prazo que o Chefe da Repartição marcar, suas mercadorias para fóra do Império, pagos os respectivos direitos; se o julgar conveniente; e não o fazendo serão postas em consumo, pagando os mesmos direitos pelo arbitramento á que se tiver procedido.

${ }^{267}$ A própria norma utilizava o termo processo para definir como se daria o arbitramento.

${ }^{268}$ Os técnicos não podiam recusar a função sob pena de serem excluídos da lista e perderem privilégios concedidos a comerciantes, a não ser em caso de moléstia ou suspeição, nos termos do art. 580 do Regulamento: “Os peritos escolhidos na fórma do $\$ 2^{\circ}$ art. 577 não poderão recusar-se a este serviço, sob pena de serem riscados de Assignantes, ou de não serem admittidos como taes, e da perda de quaesquer outras vantagens e privilegios que são outorgados aos Commerciantes pelo presente Regulamento; salva todavia a escusa por molestia provada, ou por suspeição na fórma de direito." (cf. redação original).

${ }^{269}$ Nos termos do artigo 764 do Regulamento, verbis:

Art. 764 . O recurso de revista pode ter lugar:

$1^{\circ}$ Das decisões proferidas dentro da alçada nos casos de incompetencia, excesso de poder, e violação de Lei, ou de formulas essenciaes.

$2^{\circ}$ Das decisões proferidas em juizo arbitral nos mesmos casos acima referidos 
Dentre as situações em que se previa a solução por arbitragem, incluíam-se divergência quanto à qualificação da mercadoria, havendo divergência entre as características declaradas pelo contribuinte na nota de importação e a conferência física ${ }^{270}$ (art. 559 do Regulamento), em caso de serem encontradas mercadorias omissas na tarifa de importação (artigo 566 do Regulamento) e nos casos de despacho de mercadorias ad valorem (cf. artigo 570 do Regulamento) e quando fosse necessário apurar o montante de dano havido na mercadoria no curso do despacho aduaneiro (art. 293 do Regulamento).

Como se vê, as hipóteses de controvérsia tributária que nos termos do Império podiam ser solucionadas por procedimento arbitral poderiam, também nos dias atuais, ser submetidas à solução por arbitragem, na medida em que a natureza das controvérsias, tecnicidade e complexidade das análise justificavam a solução que se impunha por definitiva entre as partes e era adotada sempre mediante opção manifestada pelo contribuinte, o que decerto permanece válidos para as relações hodiernas.

Resta, desse modo, avaliar quais as nuances do procedimento da arbitragem tributária que se cogita neste estudo, a qual, como se vê a partir do processo acima descrito, representa não absoluta inovação, mas sim adoção de prática antiga que poderá ser efetiva e eficiente desde que adequadamente levada a efeito.

\subsection{O objeto da arbitragem tributária}

Dois aspectos merecem ser analisados para se definir sobre os aspectos objetivos efetivamente solucionáveis por meio de arbitragem tributária: há possibilidade de a arbitragem tratar de assuntos tributários preventivamente à constituição do crédito tributário ou ela somente poderia ser instaurada após constituição do crédito tributário? Há limitação material da arbitragem? É o que se passa a individualmente analisar.

270 "Se a parte não concordar com a decisão do Chefe da Repartição, e a differença de direitos entre huma e outra qualificação exceder da alçada do Inspector, ou Administrador, poderá requerer que o negocio seja decidido por arbitros, e neste caso seguir-se-ha o disposto na Secção $11^{a}$ do presente Capitulo; ficando suspenso o despacho" (art. 559, parágrafo $2^{\circ}$. Redação original). 


\subsubsection{O momento de instauração da arbitragem}

A prática jurídica na defesa dos interesses dos contribuintes em controvérsias tributárias sugere que a arbitragem seja viável preventivamente à constituição do crédito tributário, na medida em que a complexidade da legislação e até mesmo das obrigações acessórias dos contribuintes merece sejam incrementados meios de diálogo entre contribuinte e fisco como forma de conferir segurança às práticas tributárias.

A Consulta fiscal ${ }^{271}$ é o meio existente atualmente para viabilizar diálogo entre fisco e contribuinte anteriormente à constituição do crédito tributário, com a segurança de vinculabilidade de ambas as partes à solução tal como definida pela administração tributária.

No entanto, as soluções de consulta por vezes não são claras o suficiente, ou mesmo objetivas, de forma a sanar adequadamente as dúvidas dos contribuintes. Ademais, a solução de consulta é unilateralmente produzida pela administração tributária e, desse modo, não há efetivamente diálogo entre fisco e contribuinte. Há, por vezes, um direcionamento produzido exclusivamente pelo fisco com pretenso caráter de orientação da postura do contribuinte.

Heleno Taveira Torres, ${ }^{272}$ que examinou tal aspecto específico da arbitragem tributária, concluiu pela possibilidade de a arbitragem ser anterior à constituição do crédito tributário e cita exemplos de controvérsias solucionáveis preventivamente à constituição do crédito tributário por juízo arbitral: fixação e definição de preço de mercado, valor venal, valor da terra nua, ou seja, conceitos amplos e abstratos, mas que possuem extrema relevância para definição de base imponível de exações, respectivamente imposto sobre a

\footnotetext{
${ }^{271}$ Sobre a natureza da consulta fiscal, ver Fabio Artigas Grillo, p. 213 e ss.

${ }^{272}$ Transação, arbitragem e conciliação judicial como medidas alternativas para resolução de conflitos entre administração e contribuintes - simplificação e eficiência administrativa, p. 51. Em outra oportunidade, o mesmo Professor reafirma seu posicionamento(Princípios da segurança jurídica e transação em matéria tributária. Os limites da revisão administrativa dos acordos tributários, p. 305-306), salientando que a existência de métodos alternativos para solução de conflitos tributários não encontra óbice na Constituição Federal na medida em que não há dispositivo constitucional vedando a sua instituição. Mais adiante, o Professor ensina que os métodos alternativos poderão tratar tanto preventivamente, quanto para solução das lides já pendentes.
} 
renda (casos de preços de transferência), Imposto sobre a Propriedade Territorial Urbana (IPTU), e Imposto Territorial Rural (ITR).

Outro campo fértil da arbitragem preventiva, salienta o Professor Heleno Taveira Torres, seria na aplicação de presunções como técnica probatória que agrega conteúdos, ${ }^{273}$ na medida em que a busca pela verdade material deve prevalecer para fins de tributação.

Quanto à possibilidade de a arbitragem se instaurar após já constituído o crédito tributário, cumpre investigar se a mesma poderá ser instaurada no curso de processo administrativo ou judicial.

Quanto à necessidade de o contribuinte renunciar a decisão administrativa quando da opção pela solução da controvérsia por arbitragem, nos termos do artigo 38 da Lei das Execuções Fiscais, o ajuizamento de medida judicial para questionar o crédito tributário importa renúncia à discussão travada na esfera administrativa. ${ }^{274} \mathrm{Na}$ arbitragem, do mesmo modo, nos parece que a opção por firmar compromisso arbitral acarreta na renúncia da adoção de solução judicial estatal para o conflito.

Parece lógico concluir, desse modo e de forma a manter a harmonia do sistema tributário, pela imediata renúncia à esfera administrativa no caso de os sujeitos ativo e passivo optarem pela solução arbitral da controvérsia tributária. Nesse exato sentido, colocam-se Alexandre Monteiro e Leonardo Castro. ${ }^{275}$

273 Para o autor, "(i)os fatos que originam obrigações tributárias e que devem ser objeto de prova dificilmente são de conhecimento direto da Administração, (ii) as pessoas que participarem efetivamente do ato tem melhor condições para produção das provas necessárias, (iii) os deveres instrumentais ou formais são ótimos instrumentos para vincular os contribuintes ao atendimento de exigências tributárias, mediante declarações etc., (iv) a praticidade dos mecanismos de arrecadação e pagamento dos tributos bem como a prevenção à incidência em faltas para as quais sejam previstas medidas sancionadoras é algo desejado pelo contribuinte" (Transação, arbitragem e conciliação judicial como medidas alternativas para resolução de conflitos entre administração e contribuintes - simplificação e eficiência administrativa, p. 53).

${ }^{274}$ Confira-se inteiro teor do dispositivo:

"A discussão judicial da Dívida Ativa da Fazenda Pública só é admissível em execução, na forma desta Lei, salvo as hipóteses de mandado de segurança, ação de repetição do indébito ou ação anulatória do ato declarativo da dívida, esta precedida do depósito preparatório do valor do débito, monetariamente corrigido e acrescido dos juros e multa de mora e demais encargos.

Parágrafo Único - A propositura, pelo contribuinte, da ação prevista neste artigo importa em renúncia ao poder de recorrer na esfera administrativa e desistência do recurso acaso interposto."

${ }^{275}$ In Direito Tributário e arbitragem: uma análise da possibilidade e dos óbices ao juízo arbitral em matéria tributária no Brasil, p. 33. 
Já na pendência de demanda judicial, não parece adequada a renúncia à discussão judicial para se optar pela discussão administrativa quanto à controvérsia tributária. De fato, em tendo sido ajuizada demanda (quer pelo fisco, quer pelo contribuinte) e havendo citação válida nos termos do $\mathrm{CPC}$, não parece viável às partes renunciarem à jurisdição estatal para busca de jurisdição privada, até mesmo porque tal opção necessariamente dependerá de compromisso arbitral.

Desse modo, sanar dúvidas em termos de interpretação e aplicação da legislação tributária é campo fértil a ser preenchido pela arbitragem tributária, na medida em que haverá, efetivamente, incentivo ao diálogo entre fisco e contribuinte e, ademais, a decisão imparcialmente tomada vinculará ambas as partes.

\subsubsection{Limites materiais da arbitragem tributária}

Campo fértil à arbitragem tributária, diante da qualidade e tecnicidade das decisões que poderão advir, são as complexas questões de fato que surgem no desenrolar das relações jurídicas de tal espécie. Cálculos complexos, aspectos contábeis que geram consequências diretas e objetivas nos aspectos da regra matriz tributária, composição de produtos e materiais, forma e quantidade de consumo de materiais nas indústrias, adequada classificação fiscal de determinado produto são exemplos de questões de alta complexidade e sobre as quais uma análise técnica é essencial ao adequado julgamento da controvérsia e, por conseguinte, tratamento do conflito.

Tanto é assim que, em juízo, tais questões são comumente objeto de prova pericial, na medida em que os magistrados, juristas que são, não possuem (e nem lhes seria exigido ter) conhecimento técnico específico necessário ao julgamento de tais questões. Também em se tratando de processo administrativo, é comum a baixa dos autos em diligência para fins de aclaramento de questões técnicas, pelas instâncias inferiores e nas quais há técnicos capazes de avaliar determinados aspectos inerentes à controvérsia. 
No sistema arbitral norte-americano, regulado pela IRS, ${ }^{276}$ os fatos já submetidos a julgamento em recurso administrativo poderão ser levados a oportuno julgamento arbitral, desde que fisco e contribuinte tenham buscado anteriormente a solução amigável do litígio e, sendo infrutífera, ambos anuam quanto aos efeitos vinculantes da decisão arbitral. Caso não tenha havido, portanto, busca por acordo, as questões não poderão ser levadas a solução arbitral.

Assim, a partir do cabimento da arbitragem tributária, não parece haver dúvidas quanto à possibilidade, adequação e viabilidade de que questões fáticas controversas possam ser submetidas a decisão arbitral.

Resta, no entanto, avaliar se simples dúvidas sobre interpretação legal poderiam ser submetidas a solução arbitral. Para Heleno Taveira Torres, ${ }^{277}$ questões mais simples, tais como dúvidas sobre a correta aplicação da lei tributária, não seriam arbitráveis, devendo permanecer solucionáveis por consultas fiscais.

Oswaldo Othon de Pontes Saraiva Filho salienta, a seu turno, a utilidade e adequação da arbitragem nos casos em que a lei não seja precisa sobre as hipóteses relevantes para fins de tributação ou mesmo sobre procedimentos, o que demandaria conhecimento técnico e cujas controvérsias seriam habilmente solucionáveis mediante arbitragem. $^{278}$

${ }^{276}$ Arbitration procedures for appeals.

${ }^{277}$ Como afirma o jurista, "em matéria tributária, a arbitragem somente poderia ser adotada para hipóteses de litígios fundados em questões materiais. Simples dúvidas sobre a aplicação da legislação tributária restariam com âmbito próprio para serem resolvidas por consultas fiscais; do mesmo modo que assuntos vinculados a matérias típicas de julgamento sobre o direito material, constitucionalidade, controle de legalidade, aplicação de sanções pecuniárias, dentre outras, continuariam sujeitas a controle exclusivo dos órgãos do processo administrativo. Em nosso entender, todas as matérias próprias de inversão do ônus da prova, por presunções e similaridades, garantem um espaço de disponibilidade, relativamente aos direitos patrimoniais envolvidos". (Transação, arbitragem e conciliação judicial como medidas alternativas para resolução de conflitos entre administração e contribuintes - simplificação e eficiência administrativa, p. 61).

${ }^{278}$ Confira-se:

"seria mais aceitável a utilização, com expressa previsão legal, de arbitragem, para solucionar, apenas, dúvida sobre questão de fato de evidente indeterminação, verificada nos casos em que os textos normativos não permitam adequada exatidão sobre as hipóteses alcançadas ou sobre os procedimentos exigidos, e requeiram conhecimentos técnicos especializados para sua compreensão. Assim, os árbitros só decidiriam questões sobre os fatos.

Mostra-se, realmente, desnecessário e inconveniente o estabelecimento de uma arbitragem, para que os árbitros interpretem a norma jurídica, questões de direito, e imponha, diante do pacto de compromisso, seu laudo à Fazenda Pública, tendo em vista a notória especialidade e expertise de agentes administrativos, como os procuradores e auditores fiscais" (A transação e a arbitragem no direito constitucional-tributário brasileiro, p. 80). 
Antonio de Souza Ribas, ${ }^{279}$ invocando a legalidade e a indisponibilidade do crédito tributário, ${ }^{280}$ traz exemplos nos quais a solução arbitral do conflito seria adequada, tais como presunções e apreciações que envolvam certo grau de subjetividade, dentre outros.

Não nos parece benéfico impedir, em termos gerais, que a arbitragem trate de determinados aspectos específicos, até mesmo porque determinada questão pode ser simples para um contribuinte mas gerar dúvidas a outros.

Por exemplo, a possibilidade de determinado produto conferir direito a crédito de PIS/COFINS pode depender de interpretação legislativa complexa, a qual poderia, a depender do interesse do contribuinte, ser solucionada por decisão arbitral. Por certo que simples questionamentos que não gerem dúvidas relevantes poderiam não ser levados à solução arbitral por falta de interesse das partes, na medida em que a relação custobenefício pode nãos ser compensatória. No entanto, se a questão é fundamental e estratégica para o contribuinte, não nos parece viável que haja óbice legal à sua solução arbitral.

Levanta-se, para analogia, a qualidade e complexidade das questões tributárias solucionáveis via mandado de segurança. É certo, de um lado, que mera dúvida interpretativa de lei ou ato normativo não viabiliza a impetração de mandado de segurança. ${ }^{281}$ Mesmo assim, a complexidade das questões tributárias solucionáveis por via mandamental é inegável e presente na realidade dos tribunais.

279 “O procedimento arbitral não pode afrontar os princípios da legalidade, nem da indisponibilidade do crédito tributário, portanto algumas condições têm que ser observadas: a) a solução arbitral só pode ser válida para decisões relacionadas com matérias de valoração jurídica incerta como - presunções, apreciações quantitativas que envolvam algum grau de subjetividade (como por exemplo, preços de mercado, preços correntes, custos correntes, etc.), apreciações qualitativas que envolvam algum grau de subjetividade, não havendo mecanismo para precisar os fatos (como por exemplo, a relação de causalidade de gasto com a atividade produtora de renda, imputação de custos ou gastos de atividades gravadas ou isentas, natureza jurídica do fato ou do ato, manobras de elisão do tributo, conceitos indeterminados amortizações, preços de transferência, etc.), métodos indiretos de taxação de bases imponíveis; b) os árbitros só podem tratar as questões em direito, jamais por equidade, devendo existir uma estreita sujeição das provas á norma”.(In Arbitragem como meio alternativo....).

${ }^{280}$ Nos termos acima expostos, entende-se que a indisponibilidade do crédito tributário é irrelevante para fins de arbitrabilidade das controvérsias tributárias. (supra, II.1.2).

${ }^{281}$ A doutrina é assente ao asseverar que não cabe mandado de segurança contra lei em tese, mormente em se tratando de lei tributária. Como afirma James Marins, "não se confunde o caráter preventivo do writ com sua utilização contra lei em tese. Somente nas ações diretas de constitucionalidade ou inconstitucionalidade é 
Têm-se, por exemplo, a questão de guerra fiscal, em pauta no Legislativo ${ }^{282}$ e também no Judiciário ${ }^{283}$ e cuja complexidade da análise é indubitável. Como se sabe, alguns estados concedem benefício fiscal sem que haja autorização do Conselho das Fazendas, em afronta ao artigo 155 , parágrafo $2^{\circ}$, XII, $g$ da Constituição Federal ${ }^{284}$ e $1^{\circ}$ da Lei Complementar 24/75. Como forma de anular os efeitos de benefícios fiscais unilateralmente concedidos, outros Estados da federação impedem que os contribuintes neles situados creditem-se do ICMS destacado em nota fiscal de transação interestadual.

A questão, a despeito de fundada em critérios legais, é por certo complexa e guarda nuances que precisam ser cautelosamente avaliadas no caso concreto, como, por exemplo, qual o montante do imposto que não pode ser creditado pelo contribuinte adquirente de mercadorias fornecidas por contribuinte beneficiado por tais incentivos irregularmente concedidos. É comum que o desconto unilateralmente concedido pelos estados não corresponda a desconto na incidência do tributo na transação interestadual, mas sim fator redutor do montante apurado ao final do exercício e devido ao Estado onde se localiza o fornecedor.

A despeito da complexidade da questão e de se tratar de questionamento meramente legal, sem aspectos probatórios ou fáticos, trata-se de controvérsia solucionável via mandado de segurança, como entende a jurisprudência que analisa a questão. ${ }^{285}$

que o Poder Judiciário se pronuncia sobre a validade ou invalidade constitucional da lei em tese, isto é, sem que se analise caso específico de incidência normativa” (Direito processual tributário brasileiro, p. 499).

A jurisprudência igualmente impede o processamento de mandados de segurança em sede tributária impetrados com manifesta intenção de questionamento da lei em tese, aplicando-se a Súmula 266 do C. STF ("Não cabe mandado de segurança contra lei em tese”), comumente aplicável na seara tributária (vide, p. ex., STF. MS 20623. Rel. Min. CELIO BORJA). Não se pode, no entanto, deixar de considerar a Súmula 625 do SFT que prescreve que "controvérsia sobre matéria de direito não impede concessão de mandado de segurança”.

${ }^{282}$ Muito se falou recentemente sobre a medida provisória que tratava da guerra dos portos (MP 595/2012), cujos termos não foram aprovada pelo Congresso.

${ }^{283}$ Já houve reconhecimento pelo STF da repercussão geral do tema no RE 628.075, sob relatoria do Min. Joaquim Barbosa.

${ }^{284} \mathrm{O}$ dispositivo estabelece que cabe preventivamente à Lei Complementar "regular a forma como, mediante deliberação dos Estados e do Distrito Federal, isenções, incentivos e benefícios fiscais serão concedidos e revogados". A seu turno, a Lei Complementar 24/75 dispõe que as "isenções do imposto sobre operações relativas à circulação de mercadorias serão concedidas ou revogadas nos termos de convênios celebrados e ratificados pelos Estados e pelo Distrito Federal". Ou seja, benefício fiscal ou incentivo concedido sem homologação do CONFAZ é inconstitucional.

${ }^{285}$ Nesse sentido, vide RMS 32453, oriundo do STJ. 
Do mesmo modo a norma que instituiu a arbitragem em Portugal (Decreto-Lei n. 10/2011) trata da possibilidade de que a arbitragem aprecie "qualquer questão de fato ou de direito", destacando, dentre as questões arbitráveis, a declaração de ilegalidade de atos.

Não parece viável, portanto, afastar da arbitragem questões tributárias complexas que, tão somente por tratarem de questionamentos em decorrência da interpretação legal, poderão ser solucionadas mediante decisão imparcial a ser imposta às partes.

Resta, enfim, verificar se a arbitragem seria meio hábil para tratar do aspecto material da hipótese de incidência tributária, sendo meio hábil de declarar inconstitucionalidade de atos normativos tributários.

Não nos parece que tal medida seria possível pois, diante da legalidade estrita e também em decorrência das prerrogativas do Judiciário, somente o Poder Judiciário pode adentrar no mérito dos atos normativos tributários e declarar sua consonância ou incongruência com o sistema constitucional tributário em vigor.

De outro lado, a lei já declarada inconstitucional por decisão irrecorrível do Supremo Tribunal Federal deve ser afastada pela decisão arbitral, administrativa ou por qualquer processo decisório previsto na legislação em vigor.

Ainda sob a égide da Constituição Federal anterior, o saudoso Geraldo Ataliba ressaltava a importância de as decisões da administração pública seguirem a Constituição e a legalidade. Ensinava o Professor que "nem pode parecer dúvida de que, ainda quando não alegada, por qualquer das partes, ilegalidade ou inconstitucionalidade, esses órgãos, no exercício da precípua função de promover o interesse público primário, haverão de deixar de aplicaras leis inconstitucionais ou os regulamentos ilegais, de ofício". ${ }^{286}$

Desse modo, há amplo campo fértil sobre o qual a arbitragem tributária poderia proporcionar soluções técnicas, céleres e adequadas, sempre de acordo com a Constituição Federal e nos termos da legalidade estrita tributária.

${ }^{286}$ In Principios informativos do contencioso administrativo tributário federal, p. 135. 


\subsection{Julgamento por equidade}

$\mathrm{O}$ artigo $2^{\circ}$ da Lei da Arbitragem estabelece que o julgamento da arbitragem pode se dar nos termos da lei ou por equidade, ${ }^{287}$ ou seja, de acordo com o que os árbitros entendem justo ao caso concreto. A seu turno, o CPC determina, em seu artigo 127, que o juiz somente decidirá por equidade nos termos em que expressamente autorizado por lei.

Em se tratando de arbitragem tributária envolvendo o Poder Público, nos parece inviável que o julgamento da controvérsia não tenha respaldo na lei, sob pena de afronta à legalidade aplicável à administração pública (Constituição Federal, artigo 37), e, mais especificamente em se tratando de controvérsia tributaria, em atenção à estrita legalidade tributária (artigo 150 da Lei Maior).

Paulo Osternack Amaral é contra o julgamento por equidade em toda e qualquer arbitragem que envolve a administração pública, ${ }^{288}$ sob pena de violação da necessária estrita legalidade, que por disposição constitucional, norteia a Administração Pública. ${ }^{289}$ Também sob o enfoque da legalidade, Lauro da Gama e Souza Jr. ${ }^{290}$ e Luis Fernando Guerrero $^{291}$ afastam a possibilidade de julgamento por equidade nas arbitragens que envolvam o poder público.

Adicionalmente às razões que levam a afastar o julgamento por equidade nas arbitragens em que o Poder Público seja litigante, haja vista a estrita legalidade tributária não seria viável o julgamento arbitral não fundado e respaldado na lei na medida em que

287 Como afirma Paulo Osternack Amaral, “o árbitro poderá decidir a controvérsia em sentido diverso daquele indicado no direito positivo - o que não significa dizer que ele deva necessariamente julgar de forma contrária àquela indicada na lei posta" (Arbitragem e administração pública..., p. 42).

Acerca do alcance e função da equidade, vale transcrever o ensinamento de SZKLAROWSKY, Leon Frejda:

"A equidade é a humanização do direito. É a mitigação da lei, segundo Aristóteles. Por meio dela, o juiz ameniza o rigor das regras jurídicas, tempera com justiça a rigidez da norma de direito, foge da norma escrita, pois o direito é bom senso, na acepção sempre atual do jurisconsulto romano Cícero. Deve o magistrado (vale também para o árbitro) fazer as adaptações possíveis à realidade social, na busca de uma solução mais justa e equilibrada, sem desprezar, naturalmente, a ética, a boa razão e, sem dúvida, a moral, princípio basilar expresso na Constituição” (In "A arbitragem uma visão crítica", p. 22).

${ }^{288}$ Vantagens, desvantagens e peculiaridades da arbitragem envolvendo o Poder Público, p. 335-336.

${ }^{289} \mathrm{O}$ mesmo autor reafirma seu posicionamento em Arbitragem e administração pública..., p.41), ao concluir pela inviabilidade de o árbitro julgar com base na equidade a controvérsia envolvendo o poder público, sob pena de ofensa ao artigo 37, caput, da Constituição Federal.

${ }^{290}$ In Sinal verde para a arbitragem em parcerias público-privadas (a construção de um novo paradigma para os contratos entre o Estado e o investidor privado), p. 37.

${ }^{291}$ Convenção de arbitragem..., p. 115. 
não haveria legitimidade para dispor sobre aspectos essenciais relativos ao crédito tributário. Não se pode admitir tributação ou mesmo qualquer atividade vinculada que não encontre respaldo legal.

\subsection{Competência para submeter o conflito à solução arbitral}

$\mathrm{O}$ artigo $1^{\circ}$ da Lei de Arbitragem prescreve que pessoas capazes poderão submeter os conflitos a solução arbitral. Carlos Alberto Carmona, a esse respeito, salienta que a aptidão para submeter conflito a arbitragem relaciona-se com a "aptidão de tornar-se sujeito de direitos e deveres, sendo tal capacidade o pressuposto de todos os direitos e obrigações". ${ }^{292}$ Não parece haver dúvidas, nesse tocante, que a lei se refere a pessoas físicas ou jurídicas, de direito público ou privado. ${ }^{293}$ Mas a discussão acerca da legitimidade do poder público instituir arbitragem não se encontra, ainda, consolidada na doutrina pátria.

Gustavo Justino de Oliveira, ao tratar dos requisitos que trazem ainda controvérsia acerca da viabilidade de o Estado solucionar controvérsias em juízo arbitral, esclarece que quanto à arbitrabilidade subjetiva não haveria dúvidas à legitimidade do poder público diante da capacidade contratual do Estado "aptidão inferida de sua personalidade jurídica de direito público", ${ }^{294}$ remanescendo questionamentos acerca da arbitrabilidade objetiva das controvérsias que envolvem o Estado.

De fato, o importante é que a pessoa a submeter o conflito para solução por arbitragem esteja no juízo perfeito e tenha capacidade para manifestação de autonomia da vontade, sendo defesa a manifestação de vontade àqueles inaptos a praticar atos da vida civil. Desse modo, a competência para legislar sobre as pessoas capazes de optar pela solução do conflito por arbitragem cabe ao Código Civil, na medida em que é o

\footnotetext{
${ }^{292} \mathrm{O}$ autor salienta que "não podem instaurar processo arbitral aqueles que tenham apenas poderes de administração, bem como os incapazes (ainda que representados ou assistidos), mas também que "entes despersonalizados (universalidades dotadas de representação ativa e passiva como condomínios em edifícios, massas falidas, espólios, sociedades de fato) podem valer-se da arbitragem, eis que têm capacidade de ser parte e de estar em juizo, nada impedindo que disponham seus direitos" (Arbitragem e processo, p. 55).

${ }^{293}$ Sobre o assunto, Fabio Brun Goldschmidt (in Arbitragem e transação tributária - verificação de compatibilidade, p. 49) salienta que a Lei da Arbitragem se refere tanto pessoas de direito público quanto de direito privado.

${ }^{294} \mathrm{~A}$ arbitragem e as parcerias público-privadas, p. 620.
} 
instrumento hábil a tratar da capacidade das pessoas. ${ }^{295}$ Sob a ótica do administrador público, sua competência dependerá de autorização legal expressa.

Luis Fernando Guerrero destaca a possibilidade de a convenção de arbitragem ser firmada por terceiros dotados de mandatos, na medida em que "na arbitragem, a capacidade do agente se verifica na medida em que este, de acordo com a legislação aplicável à arbitragem, pode comprometer-se por si, ou em casos específicos, nas hipóteses em que possa se comprometer por terceiros, como nos mandatos, nas representações comerciais etc. ${ }^{296}$

Em se tratando de conflitos internacionais, os países, na qualidade de pessoas jurídicas de direito público que são, poderão igualmente submeter controvérsias a solução arbitral, quer em se tratando de conflitos entre países, quer entre países e pessoas, desde que estejam no exercício de sua capacidade civil. ${ }^{297}$

Vale trazer o entendimento do Parecer AGU/SRG 01/2007, que considerou a Câmara de Conciliação e Arbitragem da Advocacia-Geral da União (CCAF) competente para dirimir conflitos da seara tributária na medida em que, atendidos os requisitos legais, a possibilidade de solução de conflitos tributários surgidos no seio da administração pública pela CCAF decorre da própria necessidade de a administração pública rever seus atos equivocados, à luz do entendimento que chegou a ser sumulado pelo Supremo Tribunal Federal ("STF”). ${ }^{298} \mathrm{Ou}$ seja, considerou-se a administração pública duplamente

\footnotetext{
295 Nesse exato sentido é o pensamento de Paulo Osternack Amaral, ao afirmar que "a competência legislativa para disciplinar a capacidade das pessoas recai sobre o Código Civil. Logo, a palavra pessoas mencionadas nas aludidas regras diz respeito precisamente à noção contida no Código Civil. Daí deriva a conclusão de que se incluem no conceito de arbitrabilidade subjetiva as pessoas físicas, pessoas jurídicas de direito privado e pessoas jurídicas de direito público interno (União, Estados, Distrito Federal, Territórios e Municípios, autarquias, associações públicas)"” (in, Arbitragem e administração pública..., p. 54).

${ }^{296}$ Convenção de arbitragem e processo arbitral, p. 50.

${ }^{297}$ Importante salientar que em se tratando de tributação internacional, arbitragem que trate de questões tributárias não se confunde com taxarbitrage, que pode ser definida como a transação desenhada para se obter vantagens de diferentes sistemas tributários, em transações internacionais, visando a evitar a dupla tributação. No original "tax arbitrage can be defined as transactions that are designed to take advantage of differences between national tax systems to achieve double non-taxation” (Reuven S. Avi-Yonah, International tax as international law: an analysis of the international tax regime, p. 185-186).

${ }^{298}$ Confira-se inteiro teor da Súmula: "A administração pode anular seus próprios atos, quando eivados de vícios que os tornam ilegais, porque deles não se originam direitos; ou revogá-los, por motivo de conveniência ou oportunidade, respeitados os direitos adquiridos e ressalvada, em todos os casos, a apreciação judicial".
} 
competente para solucionar conflito tributário por arbitragem, na medida em que no caso analisado o poder público figurava em ambos polos ativo e passivo da relação tributária.

O contribuinte capaz para prática atos civis, pessoalmente ou representado por procurador legalmente constituído, poderá manifestar a vontade de solucionar determinada controvérsia por arbitragem. A seu turno, a pessoa jurídica de direito público (sujeito ativo da relação jurídica tributária), mediante agende com competência legal delegada para tanto, poderá igualmente manifestar a intenção de submissão do conflito à solução arbitral.

Conclui-se que a opção pela solução arbitral da controvérsia tributária depende da capacidade das partes optantes, a saber, capacidade civil para o contribuinte e autorização legal no caso do agente público.

\subsection{Cláusula compromissória e compromisso arbitral}

A Lei da Arbitragem estabelece que a solução arbitral poderá ser acordada por meio de cláusula compromissória ou compromisso arbitral, a depender da pré-existência do litígio ou da opção das partes de pactuarem a forma de solução de conflito ainda eventual.

Vale parênteses sobre a inovação trazida pela atual Lei da Arbitragem ao conceder efeito vinculante à convenção de arbitragem, na medida em que a lei anterior somente o concedia ao compromisso arbitral, o que acabou por aproximar o procedimento arbitral brasileiro àquele dos países com mais tradição no instituto. ${ }^{299}$.

Os limites da jurisdição arbitral são os limites definidos no termo que a tal método de solução submete o conflito em apreço e, desse modo, a convenção é elemento essencial a definir a forma e abrangência da solução arbitral do conflito. ${ }^{300}$ Como ressalta Carlos

\footnotetext{
299 Para aprofundar a questão, Selma Lemes, Convenção de arbitragem e termo de arbitragem. Características, efeitos e funções.

Luis Fernando Guerrero esclarece que antes do advento da Lei de Arbitragem, a cláusula compromissória e o compromisso arbitral eram distintos em razão da forma de execução, pois a cláusula compromissória não possuía execução específica, ou seja, "qualquer negativa de instituição do juízo arbitral nas relações jurídicas que continham cláusula compromissória era, quando muito, apenada com perdas e danos, causa essa que foi indicada como primordial para a pouca utilização da arbitragem" (Convenção de arbitragem e processo arbitral, p. 9).

${ }^{300}$ Nesse sentido, vide Humberto Theodoro Junior, Arbitragem e terceiros. Litisconsórcio fora do pacto arbitral. Outras intervenções de terceiros, p. 53.
} 
Alberto Carmona, "a convenção de arbitragem tem um duplo caráter: como acordo de vontades, vincula as partes no que se refere a litígios atuais ou futuros, obrigando-as reciprocamente à submissão ao juízo arbitral; como pacto processual, seus objetivos são os de derrogara jurisdição estatal, submetendo as partes à jurisdição dos árbitros." ${ }^{301}$

Acerca da necessidade de a convenção de arbitragem estar expressa, o STJ era pelo entendimento positivo (SEC 856) e depois, reviu tal posicionamento quando do julgamento do SEC 866, mitigando a necessidade de a convenção estar expressa por força do atual dinamismo social. ${ }^{302}$ Mas a mitigação da expressa convenção arbitral poderia se aplicar à arbitragem tributaria?

Quanto à convenção de arbitragem pactuada pelo Poder Público, há doutrina que mitiga a necessidade de que haja autorização legal para firmá-la. Luis Fernando Guerrero, que profundamente analisou as formas de convenção arbitral, pensa ser necessária a expressa previsão legal para que o Poder Público possa firmar convenção de arbitragem. ${ }^{303}$

Em se tratando da arbitragem tributária, no entanto, como visto acima é necessária autorização legal expressa para adoção de tal método de solução de controvérsias. Resta saber, apenas, se a forma de fisco e contribuinte pactuarem a convenção arbitral seria ou não escrita, por compromisso ou cláusula compromissória.

Como acima mencionado, entende-se por viável a arbitragem preventiva à constituição do crédito tributário. Tal não representa dizer, no entanto, que a arbitragem seria anterior à existência do conflito. Isso porque para que o contribuinte tenha incerteza quanto ao procedimento a adotar, é necessário que (i) haja previsão normativa acerca da adequada postura, (ii) a qual gere dúvidas de interpretação e, ademais, (iii) o contribuinte que buscará dialogar com o fisco por certo entende que a norma sugere a adoção de prática que lhe seja menos benéfica.

\footnotetext{
${ }^{301}$ Arbitragem e processo, p.89.

${ }^{302}$ Nesse mesmo sentido, GUERRERO afirma que diante do atual dinamismo social é possível que a necessidade de expressa convenção arbitral seja mitigada (Convenção de arbitragem e processo arbitral, p. 56).

${ }^{303}$ Convenção de arbitragem e processo arbitral, p. 110-111.
} 
A origem da cláusula compromissória é necessariamente contratual, na medida em que as partes ao contratarem pactuarão que eventual e incerta controvérsia será decidida por arbitragem. Ora, a relação jurídico-tributária não é contratual, decorrente de manifestação da autonomia da vontade entre as partes ${ }^{304}$ e, desse modo, não seria viável que a opção pela arbitragem viesse pactuada contratualmente.

Outrossim, não parece ser razoável que haja uma "carta em branco" determinando que todo e qualquer conflito entre fisco e contribuinte, havido com relação à apuração e pagamento de determinado tributo, deva ser solucionado por arbitragem, na medida em que nem sempre a natureza da controvérsia assim admitirá.

Em se tratando de arbitragem tributária, entende-se que é necessário firmar compromisso arbitral, com fundamento legal, de forma que a abrangência da arbitragem e suas regras procedimentais estejam delineadas e pactuadas.

Outrossim, por força da estrita legalidade tributária, não seria razoável que a instituição da arbitragem fosse pactuada sem formalidades e prescrição escrita, sob pena de violação ao sistema constitucional tributário em vigor.

\subsection{Confidencialidade na arbitragem}

A regra geral aplicável ao processo civil é no sentido de que o processo é público, ${ }^{305}$ salvo em casos de segredo de justiça, nos termos do artigo155 do CPC e 93, IX da Constituição Federal. O processo judicial tributário, desse modo, a não ser que inserido nas exceções legais, ${ }^{306}$ será público.

\footnotetext{
${ }^{304}$ Sobre a vinculabilidade da tributação para ambos os sujeitos envolvidos, vide acima II.1.6.

305 Sobre a publicidade no processo civil, vide nosso Notas sobre o princípio da publicidade processual na atualidade: processo eletrônico e mídia.

${ }^{306}$ Vale destacar que usualmente, medidas cautelares fiscais, diante dos assuntos envolvidos, tramitam em segredo de justiça, na medida em que usualmente tratam de aspectos criminais.
} 
A arbitragem, a seu turno, é usualmente sigilosa. Regulamentos de câmaras arbitrais tratam da possibilidade de o procedimento arbitral não ter publicidade (p.ex. CCI - art. $6^{\circ}$ do apêndice I, Câmara de Mediação e Arbitragem de São Paulo, cláusula 17.4 e Amcham, cláusula 15.1) e dessa forma usualmente estabelecem as partes.

Em contrapartida, em se tratando de litígio envolvendo o poder público, não seria adequado que o procedimento arbitral corresse sigilosamente, na medida em que a publicidade dos atos da administração pública é constitucionalmente delineada (cf. artigo 37 da Constituição Federal) e, ademais, a tendência é pela ampla publicidade de atos e aspectos dos diversos braços da administração pública. ${ }^{307}$ Carlos Alberto de Salles, ao estudar a arbitragem nas relações contratuais da administração pública, defende que a confidencialidade da arbitragem deve, ao mesmo tempo, respeitar a publicidade que envolve a administração pública mas, de outro lado, garantir responsividade ao procedimento arbitral. $^{308}$

Carlos Alberto Carmona ${ }^{309}$ ressalta que a confidencialidade na arbitragem, por muitos apontada como óbice à viabilidade da solução arbitral do conflito que envolve o poder público, é uma tendência da arbitragem e não aspecto intrínseco do procedimento. Trata-se, como ressalta Carmona, de "falso dilema, já que o sigilo é uma característica que pode - apenas pode - ser estabelecida pelas partes, nada impedindo que os litigantes, por qualquer razão, abram mão da confidencialidade que geralmente cerca o procedimento arbitral". 310

No âmbito tributário, no entanto, não se vislumbra hipótese de que o sigilo na arbitragem seja recomendável para garantir efetividade da tributação ou, alternativamente,

\footnotetext{
307 Nesse sentido, mencione-se a recém publicada Lei de Acesso à Informação (lei n. 12.527/2011), que determina que todos os órgãos da administração pública deverão publicar na internet informações essenciais, tendo havido expressa determinação inclusive da divulgação dos recebimentos dos servidores. Marco importante da publicidade relativa à administração pública, outrossim, foi a lei de responsabilidade fiscal (lei complementar 101/2000), que determina, dentre outros aspectos, a publicação dos orçamentos públicos (art. $8^{\circ}$ ) e do Relatório Resumido da Execução Orçamentária (art. 52).

${ }^{308}$ Arbitragem em contratos administrativos, p. 55-57.

${ }^{309}$ Arbitragem e processo, p. 67.

310 Também pela inexistência de qualquer óbice decorrente da confidencialidade em se tratando de arbitragem que envolve o poder público, vide Lauro da Gama e Souza Jr., Sinal verde para a arbitragem em parcerias público-privadas (a construção de um novo paradigma para os contratos entre o Estado e o investidor privado), p. 35.
} 
respeitar a intimidade do contribuinte quanto às informações disponibilizada, além daquelas hipóteses que justificariam ser sigiloso o processo judicial.

A não ser que a situação se insira nos termos das exceções previstas no artigo 155 do CPC, ou seja, situação extraordinária que exige sigilo processual nos termos da lei, entende-se que a arbitragem tributária deverá ser pública e acessível a todos.

Vale mencionar, por fim, o entendimento de Luis Fernando Gerrero ${ }^{311}$ no sentido de que a arbitragem envolvendo o poder público não poderia ter sua validade questionada tão-somente por ter corrido sigilosamente. Outros aspectos deveriam ser analisados antes de se decretar a nulidade da arbitragem, tais como eventual conluio ou aproveitamento ilícito por parte do contribuinte.

\subsection{A definição do procedimento da arbitragem}

As partes podem dispor sobre o procedimento da arbitragem e tal maleabilidade é frequentemente apontada com uma das grandes vantagens da solução arbitral das controvérsias. $^{312}$ Riskin e Westbrook, ${ }^{313}$ por exemplo, ao definir a arbitragem, ressaltam que a possibilidade de as partes decidirem o procedimento pode resultar num julgamento mais célere, menos formal e menos custoso.

A Lei da Arbitragem, nos artigos 19 a 22, traz alguns aspectos procedimentais da arbitragem e estabelece, no artigo 21, que as partes podem adotar o procedimento estabelecido (sugerido) pelo tribunal arbitral ou delegarem ao próprio árbitro ou tribunal a definição do procedimento. As câmaras arbitrais disponibilizam aos interessados sugestões de procedimento, os quais podem, total ou parcialmente, ser adotados pelas partes. Não é incomum, no entanto, que as partes estabeleçam aspectos especiais do procedimento da arbitragem que enfrentarão. As arbitragens contratuais, desse modo, costumam possuir procedimento próprio, de acordo com as necessidades das partes e da especificidade das controvérsias.

${ }^{311}$ Convenção de arbitragem e processo arbitral, p. 114.

${ }^{312}$ Marc Galanter ressalta que a possibilidade de escolha de procedimento não representa indiscriminado informalismo da arbitragem (Introdução comparado a quê? Avaliando a qualidade dos mecanismos de solução de disputas,).

${ }^{313}$ Dispute resolution and lawyers, p. 3. 
A OECD, na convenção modelo sugere, em seu artigo 25 traz alguns aspectos comuns aos procedimentos arbitrais internacionais, tais como (i) ser necessária prévia tentativa de solução da controvérsia por intermédio de procedimento amigável, (ii) para se instaurar a arbitragem, é essencial que as autoridades competentes não tenham logrado resolver a controvérsia por meio do procedimento amigável, (iii) deve ter havido transcurso do prazo de 2 anos contados a partir da apresentação do caso ao outro Estado contratante, (iv) o caso somente poderá ser submetido à arbitragem caso não tenha sido objeto de decisão administrativa ou judicial em um dos Estados contratantes. ${ }^{314}$

Ou seja, especificamente no tocante a controvérsias tributárias internacionais, a despeito de não haver disposição quanto a todos os aspectos do procedimento arbitral a ser adotado, há algumas sugestões que, a despeito de não engessarem o procedimento, conferem determinados aspectos considerados essenciais sob o ponto de vista da OECD.

Em se tratando de arbitragem tributária interna, não parece viável que haja um procedimento engessado, na medida em que cada arbitragem poderá demandar procedimento específico haja vista as questões a serem resolvidas. Assim, por certo uma arbitragem que busque sanar dúvida quanto a procedimento acessório demandará um procedimento absolutamente distinto daquela destinada a conferir cálculos de forma a apurar a pertinência ou não do lançamento tributário ${ }^{315}$ que já tenha sido formalizado pelo fisco.

\footnotetext{
${ }^{314}$ Sobre a arbitragem internacional, cita-se interessante conclusão alcançada por Eduardo Silva Romero a partir da análise de caso julgado pela ICC, em Paris, na qual, a despeito de a arbitragem tratar de assunto relativo ao país de residência dos contratantes, o procedimento eleito foi o da câmara arbitra, localizada em outro país: (do original: "If the arbitrationisbased on anarbitrationagreementcontained in Statecontract, the lawapplicableto the characterization of the legal relationship and the arbitrationwillbethat of the seat of the internationalarbitration, if no internationalconventionisapplicable. Where the law of the seat contains a formal definition of the international nature of an arbitration, international arbitrators may, if the parties both come from the same State, decide that the legal relationship is national and accordingly decline jurisdiction over the dispute. If, on the other hand, the law of the seat contains an economic definition of the international nature of an arbitration, international arbitrators may, in the same circumstances, find that the legal relationship is international and that they therefore have jurisdiction over the merits. Such a decision was made in a recent ICC case, in which the seat was in Paris and the parties were nationals of the same Latin American State." (ROMERO, Eduardo Silva. "International arbitration involving state parties. Observations on the applicable Law in state contract arbitration", p. 190-191).

${ }^{315}$ Do mesmo modo ocorre com os processos judiciais tributários: os Embargos à Execução Fiscal e ações anulatórias de débito fiscal possuem procedimento diverso a depender da questão de mérito sub judice. De outro lado, os mandados de segurança possuem procedimento próprio e hábil a julgar determinadas questões tributárias, mas há lides não solucionáveis na via mandamental, que demandam dilação probatória e exigem o procedimento ordinário para solucioná-las.
} 
Tomemos, por oportuno, o exemplo da doutrina britânica. ${ }^{316}$ Por força da natureza contratual da arbitragem, se apresentam quatro nuances contratuais que estariam, necessariamente, envolvidas numa arbitragem: o contrato sobre o qual a disputa se refere (substantive contract), o contrato por meio do qual as partes anuem pela adoção da arbitragem (agreement to arbitrate), o contrato entre as partes e o tribunal arbitral, que o adota para solução do conflito e, finalmente, o contrato existente entre as partes e os árbitros. ${ }^{317}$

Acerca da importância da maleabilidade do procedimento da arbitragem, a norma portuguesa que instituiu o procedimento no país, ${ }^{318}$ salienta que o engessamento do procedimento poderia atrapalhar a necessária celeridade do processo arbitral, prescrevendo um "processo sem formalidades especiais".

Seriam, em suma, os aspectos essenciais a ser objeto de acordado entre as partes e, ao que parece, não seria viável engessar tais escolhas mediante pré-definição legal, sob pena de mitigar característica essencial da arbitragem.

Acerca da definição do procedimento da arbitragem, Carlos Alberto Carmona ${ }^{319}$ salienta que há, sim, rigor no procedimento arbitral e apresenta, exemplificadamente, as hipóteses em que os árbitros deverão ou não seguir a lei processual, salientando que os princípios processuais devem nortear o procedimento de todo e qualquer tribunal arbitral. $\mathrm{O}$ autor salienta, ainda, que qualquer alteração no procedimento deverá necessariamente ser avisada às partes, para que o julgamento arbitral ocorra da melhor forma e sem surpresas procedimentais indesejáveis a ambas as partes.

\footnotetext{
${ }^{316}$ Tendo por base o Arbitration Act 1996.

${ }^{317}$ Susan Brake, Julie Bowne e Stuart Sime, A practical approach to Alternative dispute resolution, p. 373.

${ }^{318}$ Decreto-Lei n. 10, de 20 de janeiro de 2011.

${ }^{319}$ In Flexibilização do procedimento arbitral, Revista Brasileira de Arbitragem, n. 24, out-dez. 2009, p. 11.
} 
Conclui-se, desse modo, que há certos aspectos que, s.m.j., a lei deve expressamente dispor, tais como o momento no qual a arbitragem poderia ser instaurada, ${ }^{320}$ a quantidade mínima de árbitros a compor o tribunal arbitral, ${ }^{321}$ a forma de se operar a eleição pela solução arbitral do conflito, a inviabilidade de instauração de arbitragem $a d$ $h o c^{322} \mathrm{e}$, finalmente, a impossibilidade de julgamento por equidade. Como salienta Carlos Alberto de Salles, a falta de indicação sobre como deverá instituir o juízo arbitral e como será a escolha dos árbitros "sem dúvida, reduz a efetividade da solução arbitral, expondo as partes ao risco de precisarem recorrer ao Judiciário para esse fim”." ${ }^{323}$

\subsubsection{O tribunal arbitral}

A adequada sistemática de escolha do tribunal arbitral é essencial ao bom funcionamento da arbitragem e as condições e garantias dos julgadores devem igualmente ser resguardadas de forma a conferir adequado tratamento das controvérsias. ${ }^{324}$

\footnotetext{
${ }^{320}$ Nesse sentido, Aurélio Pitanga Seixas Filho salienta que o contribuinte que, após término da discussão administrativa, optar pela submissão da controvérsia ao tribunal arbitral, estaria impedido de buscar o judiciário para solução da controvérsia (SEIXAS FILHO, Aurélio Pitanga. A solução de controvérsias fiscais por meio de arbitragem, p. 94).

${ }^{321}$ É necessário cláusula cheia na arbitragem que envolve o poder público, de forma que, ao se indicar pelo menos a forma de nomear o árbitro (conforme Carlos Alberto Carmona, O processo arbitral, p. 25) conferirse-á maior responsividade ao método.

${ }^{322}$ A arbitragem ad hoc a qual para Carlos Alberto Carmona deve ao menos indicar se as partes pretendem árbitro único ou colégio arbitral (O processo arbitral, p. 26), não se mostra compatível com a controvérsia tributária na medida em que, em se tratando de conflito com o poder público, é necessário que se afaste possibilidades de desvio de finalidade do método. A arbitragem ad hoc permite tamanha informalidade que seria incompatível com a estrita legalidade tributária e, também, possibilitaria desvios por parte dos julgadores em prejuízo ao interesse público, assim entendido como o interessa da coletividade de ver a controvérsia julgada da melhor forma, no menor tempo e com o menor custo possível.

${ }^{323}$ Arbitragem em contratos administrativos, p. 275.

${ }^{324}$ Nesse sentido, vale transcrever o sempre preciso ensinamento de Geraldo Ataliba acerca dos critérios e garantias dos julgadores do contencioso administrativo tributário vis a vis a confiabilidade do sistema (in Recurso em matéria tributária, p. 122-124):

"A rigor, só se pode dizer que haja contencioso nos sistemas jurídicos que atribuem a tal organismo parcelas de poder (competências) quase judicial, que se caracteriza pela definitividade de suas decisões. É requisito essencial, neste caso - segundo os padrões constitucionais próprios do Estado de Direito -, que os julgadores gozem de condições objetivas e subjetivas de atuação imparcial. Que os seus cargos sejam dotados das características de uma magistratura. Isto decorre do princípio segundo o qual ninguém pode ser juiz e parte concomitantemente.

(...)

Nesse sistema, organismos integrados por quase-magistrados - cujas garantias individuais repousam mais em vetusa e respeitada tradição do que em normas expressas - dirimem as controvérsias também fiscais.

(...)

Para que tenham eficácia, é fundamental que os julgadores gozem de condições funcionais efetivas de independência.
} 
Nesse tocante, a eleição de um único árbitro para solucionar a controvérsia tributária não seria recomendável. Isso porque a decisão tomada por maioria é mais certa e segura, sobretudo ao se considerar que o mérito da decisão arbitral não poderá ser revisto sequer pelo Judiciário. Carlos Alberto de Salles, na análise da arbitragem que envolve o Poder Publico, ressalta que a escolha de um tribunal arbitral é recomendável por ser mais facilmente encontrado o consenso desse modo. ${ }^{325}$

Há no Brasil, no entanto, órgãos paritários ${ }^{326}$ administrativos, compostos equitativamente por julgadores representantes do fisco e dos contribuintes, e suas decisões são submetidas ao Judiciário quando desfavoráveis ao contribuinte mediante iniciativa do mesmo ou, alternativamente, caso não seja pago o débito, mediante iniciativa privativa da pessoa jurídica de direito público com o ajuizamento de executivo fiscal.

A adoção de arbitragem para julgamento por órgão paritário, desse modo, não diferenciaria a arbitragem do julgamento pelas instâncias superiores administrativas. Devese, assim, formular a composição arbitral de forma que não se constitua novo tribunal administrativo.

\subsubsection{A composição do tribunal arbitral}

A lei deve, de forma a conferir a seriedade e responsividade à arbitragem,trazer critérios mínimos para que as partes possam escolher os árbitros. A grande vantagem da tecnicidade dos árbitros é essencial para que a arbitragem possa produzir o esperado resultado. Como ressalta Paulo Osternack Amaral "nada mais natural do que se esperar

Mas é igualmente decisivo que esses julgadores atuem conscientes do cunho dogmático do direito positivo e, como para-magistrados ou quase-magistrados, falam justiça formal, promovendo, nessa sua atuação, eficientemente, o interesse público primário - na concepção de CELSO ANTONIO e ALESSI.

Quanto mais próximos os sistemas estiverem desses padrões, melhor será a confiabilidade dos resultados de sua ação".

${ }^{325}$ Arbitragem em contratos administrativos, p. 277

${ }^{326}$ Sobre a composição paritária dos tribunais administrativos tributários, vide CARVALHO, Fabio Junqueira de; MURGEL, Maria Inês. "Órgão julgador administrativo - necessidade de o mesmo ser paritário", p. 27-44. 
uma decisão tecnicamente mais adequada, mais precisa do que a que seria prolatada no Judiciário". 327

A vantagem da especialidade dos árbitros (se comparada a arbitragem ao julgamento adjudicatório) é tamanha que na própria definição de arbitragem apresentada por Riskin e Westbrook ${ }^{328}$ ressalta-se especificamente a possibilidade de as partes escolherem um julgador com conhecimento e experiência para solução adequada da controvérsia.

Carlos Alberto Carmona ${ }^{329}$ aponta as diferenças entre o juiz e o árbitro, ressaltando que as partes, ao optarem pela solução arbitral, não estão à procura de método livre de solução do conflito, mas sim possuem intenção de obter um mecanismo mais flexível. Por isso, quanto ao papel do árbitro, salienta o Professor que os árbitros devem, sim, aplicar a lei tal como fariam os juízes estatais. $\mathrm{O}$ autor ressalta que os árbitros, diante de sua qualificação, poderão "estudar melhor o caso, avaliar melhor as provas, perquirir melhor as normas jurídicas que regem a espécie e terão oportunidade de fazer um bom julgamento”. Um bom juiz, se tivesse condições de se dedicar a caso único sem se perder nas inúmeras decisões que seu ofício exige sejam proferidas, poderia igualmente proporcionar um julgamento de alta qualidade técnica.

Assim, é importante que os árbitros detenham conhecimento técnico específico ${ }^{330}$ na área de atuação. Aspectos contábeis tributários devem ser julgados por experts contábeis; dúvidas quanto à classificação fiscal de alimentos, por exemplo, devem ser

\footnotetext{
${ }^{327}$ Vantagens, desvantagens e peculiaridades da arbitragem envolvendo o Poder Público, p. 333.

${ }^{328}$ RISKIN, Leonard L e WESTBROOK, James E. Dispute resolution and lawyers, p. 3.

${ }^{329}$ Flexibilização do procedimento arbitral, p. 11.,

${ }^{330}$ Quanto à tecnicidade dos julgamentos, Paulo Osternack Amaral ressalta que "como a tendência é que sejam escolhidos árbitros com conhecimento especializado na matéria objeto do litígio, nada mais natural do que se esperar uma decisão tecnicamente mais adequada, mais precisa do que a que seria prolatada no Judiciário".

Justamente acerca da especialidade e escolha dos árbitros, Carlos Alberto de Salles salienta que "de fato, considerando não haver exigência de o árbitro ter formação jurídica, a especialidade do árbitro pode estar ligada a uma grande diversidade de fatores, como a expertise técnica de uma determinada área ou simplesmente o conhecimento, ainda que leigo, dos costumes e práticas comerciais de determinado setor. Nesse sentido, por exemplo, um engenheiro pode estar credenciado para uma disputa envolvendo a conclusão de uma obra ou um comerciante experiente habilitado para decidir uma questão relativa à qualidade do algodão em um determinado contrato de fornecimento" (Arbitragem em contratos administrativos, p. 49-50).
} 
solucionadas por ao menos um especialista técnico em química ou engenharia química; e assim por diante.

Na arbitragem portuguesa delineada pelo Decreto-Lei n. 10/2011, delineou-se a formação de um Centro de Arbitragem Administrativa composto por árbitros que no biênio anterior a sua nomeação não podem ter feito parte dos quadros da administração tributária ou prestado serviços jurídicos (auditoria, consultoria, jurisconsultoria ou advocacia) aos sujeitos passivos ${ }^{331}$.e, na hipótese de o contribuinte optar por nomear um árbitro, o julgamento se dará necessariamente por três julgadores.

Outrossim, é importante que pelo menos um dos árbitros tenha experiência anterior em procedimentos arbitrais. ${ }^{332}$ Tais prerrogativas se amoldam perfeitamente à necessidade de conflitos tributários de alta especialidade e complexidade e, além do mais, diferirão a composição do tribunal arbitral dos tribunais administrativos já existentes, eis que compostos exclusivamente por fiscais e advogados representantes dos contribuintes.

\subsection{Cumprimento da sentença arbitral e o Judiciário}

A Constituição Federal garante a efetividade de jurisdição e, desse modo, determina que a jurisdição arbitral, se as partes assim elegerem, seja justa e efetiva. Gilberto Giusti ${ }^{333}$ ressalta a necessidade de cooperação entre árbitro e juiz na medida em que ao processo civil o que interessa é a efetividade da tutela dos direitos, independente de se tratar de processo estatal ou alternativo ao estatal.

Antes do advento da lei de arbitragem em vigor, a sentença arbitral precisava ser homologada pelo Poder Judiciário para ter validade, nos termos da antiga disposição do art. 1.100 do CPC, e justamente após mitigação dessa necessidade com a atual redação do artigo $475-\mathrm{N}$ do $\mathrm{CPC},{ }^{334}$ a arbitragem passou a ser mais comumente adotada.

\footnotetext{
${ }^{331}$ Cf. artigo $8^{\circ}$ do Decreto-Lei 10/2011.

${ }^{332}$ Nesse sentido, Paulo Osternack Amaral, em Vantagens, desvantagens e paculiaridades da arbitragem envolvendo o Poder Público, p. 334.

${ }^{333}$ GIUSTI, Gilberto. O árbitro e o juiz: da função jurisdicional do árbitro e do juiz, p. 13.

${ }^{334}$ Com redação pela Lei n. 11.232/2005.
} 
Vale, inicialmente, tratar da possibilidade de as partes buscarem a solução arbitral antes de instaurado o tribunal arbitral, em medidas cautelares preparatórias do procedimento arbitral. Por vezes, a necessária coercibilidade exclusivamente exercida pelo Judiciário poderá ser chamada de forma a conferir pressupostos para validade do procedimento arbitral. Isso, por certo, sem prejuízo da possibilidade de o fisco ajuizar medida cautelar fiscal para garantir a honra de crédito tributário já constituído mas ainda não executável judicialmente.

É importante, de forma a ser efetiva, que a sentença arbitral vincule tanto o fisco quanto contribuinte. ${ }^{335}$ Mas, tal como ocorre com a arbitragem comercial, a arbitragem tributária prescindirá de interferência judicial em determinados momentos, ${ }^{336}$ sendo certo que o mérito da decisão arbitral não poderá ser revisto pelo judiciário a não ser nos casos de comprovada anulabilidade ${ }^{337}$ da sentença arbitral. ${ }^{338}$

Em termos de validade do processo arbitral, o legislador cuidou de pincelar princípios processuais constitucionais e vincular a legalidade e a validade da arbitragem à sua observação, trazendo expressa menção ao contraditório, igualdade entre as partes, imparcialidade do árbitro e seu livre convencimento. Como destaca Carlos Alberto

${ }^{335}$ O Decreto-Lei 10/2011, que instituiu a arbitragem em Portugal, em seu artigo 24, estabelece que a decisão arbitral vincula a administração pública, trazendo as providências que se farão necessárias a partir de então. Na exposição de motivos, ressalta-se "a irrecorribilidade da decisão proferida pelos tribunais arbitrais".

${ }^{336}$ A doutrina aponta três momentos em que poderá haver interferência do judiciário na arbitragem. $\mathrm{O}$ primeiro deles se dá no momento anterior à instauração da arbitragem, quer quando da definição da convenção arbitral, quer em sede de medidas preparatórias ao procedimento que será instaurado. O próprio artigo $9^{\circ}$ da LA permite que a convenção de arbitragem seja judicial. Outro momento se dá no curso da arbitragem, a exemplo da hipótese prevista no artigo 25 da LA ou mesmo em caso de necessidade de concessões de medidas cautelares vinculadas à arbitragem. Cite-se, a título exemplificativo, a decisão proferida no proc. 053.10.017261-2, que consiste em interferência do Judiciário para fins de definição da prova pericial adequada (de engenharia ou contabilidade) à liquidação de sentença arbitral em processo no qual colidem o Metro e o Consórcio Via Amarela em arbitragem julgada pela Câmara Internacional de Comércio (ICC). O terceiro momento reside justamente no momento de se pleitear a anulação da decisão arbitral, nos termos aqui tratados.

Vale, no mais, destacar as anti-suit injunctions, que correspondem a decisão judicial estatal impedindo as partes de instaurar arbitragem perante jurisdição diversa (sobre o tema, vide NUNES, Thiago Marinho, A prática das 'anti-suit injunctions' no procedimento arbitral e seu recente desenvolvimento no direito brasileiro, Revista Brasileira de Arbitragem, n. 5, jan/mar/2005, PP. 15-51.

${ }^{337}$ Carlos Alberto Carmona ressalta que as hipóteses descritas no art. 32 da LA não tratam de nulidade da sentença arbitral, mas sim de sua anulabilidade (Arbitragem e processo..., p. 317).

${ }^{338}$ As hipóteses de anulabilidade da sentença arbitral se encontram taxativamente (hipóteses taxativas consoante entendimento de Carlos Alberto Carmona, Arbitragem e processo..., p. 318) expostas no artigo 32 da Lei da Arbitragem, a saber: nulidade do compromisso, incompetência do árbitro, desatendimento aos requisitos do artigo 26 da LA, desrespeito aos limites da convenção de arbitragem, comprovação de prevaricação, concussão ou corrupção passiva, desrespeito ao prazo do art. 12 da LA ou dos princípios de que trata o art. 21 da norma (quais sejam, contraditório, igualdade entre as partes, imparcialidade do árbitro e seu livre convencimento). 
Carmona, "a preocupação com os princípios atinge o processo arbitral, e ao apenas o procedimento, pois é claro o intuito de tutelar a relação jurídica que se instaura entre partes e árbitro, e não apenas a forma e a sequencia dos atos que serão praticados por uns e outro". 339

Flavio Yarshell ${ }^{340}$ salienta a subsidiariedade do controle jurisdicional da sentença arbitral e apresenta as semelhanças entre a medida judicial ajuizada para anular a sentença arbitral e a ação rescisória da decisão judicial, sobretudo porque em ambos os casos somente será admissível a pretensa anulação da decisão quando esgotados os esforços para sua integração (quer mediante interposição dos recursos cabíveis, quer mediante anulação da sentença arbitral para que nova decisão seja proferida extrajudicialmente). $\mathrm{O}$ autor fala do "dever de empregar todos os meios possíveis para solucionar a controvérsia de forma diligente e de boa-fé”. Conclui o autor que "a ação anulatória prevista pelo art. 32 da Lei de Arbitragem tem caráter subsidiário, entendendo-se como tal o fato de que, enquanto cabível impugnação no âmbito da própria arbitragem contra a solução de mérito, o controle estatal fica obstado”.

Como se vê, na arbitragem tributária a revisão judicial dependerá de falhas viscerais do procedimento arbitral e está jungida às hipótese legais.

Outrossim, o tribunal arbitral não possui prerrogativa de impor suas decisões às partes envolvidas na controvérsia pois não é imbuído de coercibilidade. Também nesses casos será necessário buscar o judiciário para exercício do poder coercitivo.

Assim, a decisão arbitral favorável ao fisco e não honrada pelo contribuinte poderá gerar certidão da divida ativa e consequente ação executiva fiscal. De outro lado, caso o fisco se negue a dar cumprimento à decisão arbitral, o contribuinte poderá buscar o judiciário e seus meios coercitivos para garantir efetividade da decisão.

\footnotetext{
${ }^{339}$ Arbitragem e processo..., p. 252.

${ }^{340}$ In Caráter Subsidiário da ação anulatória de sentença arbitral, p. 13.
} 


\subsection{Possibilidade de constituição de obrigação pecuniária contra a fazenda pública}

A Constituição Federal veda expressamente que a tributação tenha efeito confiscatório em seu artigo 150, IV e, ademais, o direito de propriedade é garantido a todos no art. $5^{\circ}$, inc. XXII também da lei maior.

Justamente como forma de se evitar que o locupletamento ilícito do ente tributante prevaleça, o CTN trata da ação de repetição do indébito tributário em seus artigos 165 a 169, a qual se fundamenta nos princípios da legalidade, tipicidade estrita, capacidade contributiva, moralidade $^{341}$ e, pela letra do CTN, o contribuinte somente poderá reaver ${ }^{342}$ valores indevidamente reconhecidos mediante decisão judicial transitada em julgado. $\mathrm{Ou}$ seja, por disposição de lei complementar, vislumbra-se a possibilidade de que seja recuperado o montante reconhecidamente recolhido a maior ao Erário, o qual pode ser composto por principal, encargos e multas punitivas. ${ }^{343}$

Poderia a sentença arbitral, nesse cenário, reconhecer o indébito tributário e constituir crédito em favor do contribuinte? Veja-se, a esse tocante, qual a razão que pode ter levado o legislador a determinar que a sentença judicial definitiva teria o condão de condenar o Estado a restituir ao contribuinte. Trata-se, por certo, de julgamento imparcial, feito por terceiro não envolvido na controvérsia, sujeito a graus hierárquicos de jurisdição que conferem confiabilidade e imparcialidade ao julgamento.

Diante de todo o acima avaliado, as características que conferem à decisão judicial confiabilidade e imparcialidade se encontram presentes na sentença arbitral, a qual, em adição aos predicados da sentença adjudicada, possui uma especialidade dos julgadores que, s.m.j., incrementam a confiabilidade se comparada à decisão judicial.

$\mathrm{O}$ aspecto divergente da sentença judicial e da arbitral que merece ser ressaltado para análise do que se propõe consiste justamente no fato de a decisão judicial possuir

\footnotetext{
${ }^{341}$ Os princípios que justificam a ação judicial em voga são elencados por Marins, James, Direito processual tributário brasileiro, p. 441-443.

${ }^{342}$ Vale destacar que há entes federativos que viabilizam a compensação desse crédito reconhecido por decisão judicial transita em julgado com tributos vincendos, a exemplo do que dispõe o artigo 74 da Lei $\mathrm{n}$. 9.430/96. De outro lado, sempre restará ao contribuinte a expedição de ofício precatório como forma de receber os valores objeto do indébito tributário.

${ }^{343}$ Artigo 167 do CTN.
} 
coercibilidade, enquanto a sentença arbitral, caso não seja prontamente cumprida pelas partes, prescindirá do Judiciário para se fazer efetiva. Resta saber se a falta de tal predicado afastaria a possibilidade de a sentença arbitral reconhecer e, sobretudo, constituir o direito do contribuinte à repetição do indébito tributário. Tal verificação guarda direta relação com as formas de execução da decisão judicial condenatória proferida em desfavor do poder público.

A Constituição Federal, em seu artigo 100, é expressa ao determinar que o ofício precatório decorre da sentença judiciária. A partir da análise do dispositivo, duas leituras se fazem possíveis. Uma delas é no sentido de que a sentença judiciária seria a decisão de mérito condenatória da fazenda pública; a outra hipótese reside justamente no fato de se possível tratar-se de sentença proferida em processo de execução de título extrajudicial, ou seja, a Constituição não veicularia necessidade de a decisão de mérito ser instrumento da condenação contra a fazenda pública. Nesse caso, seria viável que o contribuinte recebesse o indébito tributário reconhecido em sentença arbitral.

A legislação vigente e em especial o artigo 730 do Código de Processo Civil, ao regular o processo de execução para os fins de promover a executividade das obrigações inadimplidas pela fazenda pública, não fixou qualquer distinção entre os títulos judiciais e os extrajudiciais. Tanto é assim que, mesmo após mudanças viscerais no procedimento de cumprimento das sentenças judiciais (cf. artigos 475-I e seguintes do CPC, com relação pela Lei n. 11.232/2005), a execução de sentença em face da fazenda pública permanece regulada pelo artigo 730 do Codex processual. Ademais, tanto o CPC ao definir a sentença arbitral como título executivo (artigo 475-N, IV) quanto a Lei da Arbitragem (em seu artigo 31$)^{344}$ equiparam os efeitos das sentenças arbitral e judicial, de forma que a sentença arbitral será sempre título executivo judicial. ${ }^{345}$

Desse modo, é viável, pelo CPC, que a decisão proferida em processo de execução de título executivo correspondente a sentença arbitral seja instrumento hábil a determinar a expedição de ofício precatório para pagamento de condenação havida contra o poder

\footnotetext{
${ }^{344}$ Que estabelece que “A sentença arbitral produz, entre as partes e seus sucessores, os mesmos efeitos da sentença proferida pelos órgãos do Poder Judiciário e, sendo condenatória, constitui título executivo”.

${ }^{345}$ Nesse sentido, vale destacar o entendimento de Carlos Alberto Carmona, que traz as diversas disposições do CPC acerca da sentença arbitral e conclui que a decisão se equipara à sentença judicial também em termos de procedimentos para sua execução (Arbitragem e processo..., p. 315).
} 
público $^{346}$ mediante processo de execução contra a fazenda pública (o qual, como visto, não distingue na letra do CPC a sentença judicial da extrajudicial).

Vale mencionar que a discussão acerca da possibilidade de que contra a fazenda pública caiba a execução forçada, ${ }^{347}$ fundada em título extrajudicial sempre desafiou os juristas e, a partir da promulgação da Carta Constitucional de 1988, porém, essa celeuma foi de todo superada em virtude dos princípios constitucionais vigentes e da firme posição adotada pelos Tribunais Superiores ${ }^{348}$ e hodiernamente sumulada pelo STJ. ${ }^{349}$

Ou seja, a decisão arbitral é dotada de imparcialidade, efetividade, especialidade e exequibilidade necessárias ao reconhecimento do indébito tributário. Restaria, apenas, mediante reforma do texto legal do CTN, incluí-la dentre os instrumentos capazes de reconhecimento do locupletamento ilícito do ente tributante.

${ }^{346}$ Nesse exato sentido vale transcrever julgado oriundo do STJ:

"RESP - Processual Civil - Fazenda Publica - Execução - Titulo Extrajudicial. - A execução contra a Fazenda Pública obedece o procedimento do Art. 730, CPC e seguintes. A exigência do art. 100, $C F / 1988$, impondo, para expedir precatório, sentença judiciária, não interfere na conclusão. $O$ estado pode efetuar pagamento, independente de precatório: vencimentos de servidores, obrigações decorrentes de contrato para a realização de obras públicas. Também pagamento de alugueres. Impõe-se distinguir: o precatório deve ser precedido de "sentença judiciária". Esta é pressuposto. Não exclui, entretanto, a execução por titulo executório extrajudicial. Dever-se-á entender teleologicamente os dispositivos legais. Confere-se, pois, equilíbrio aos interesses do particular e do estado. Extremo formalismo reclamar processo de conhecimento para conferir o titulo executório extrajudicial. Entenda-se, para efeito do art. 100, CF/1988 - sentença judiciária - como verificação judicial do débito reclamado. Acontece, no processo executório, haja, ou não embargos do devedor" (RESP 98104 - Min. LUIZ VICENTE CERNICCHIARO - DJ DATA:16/12/1996 PG:50992)

${ }^{347}$ Sobre a execução provisória por quantia certa contra a Fazenda Pública, veja estudo de HOSSNE, Beatriz de Araujo Leite Nacif, Da execução por quantia certa contra a Fazenda Pública: aspectos polêmicos.

${ }^{348}$ Esse é o entendimento de Flavio Yarshell:

"Estas, de forma genérica, são as medidas predispostas à tutela das obrigações de fazer e não fazer. Como isso se coloca diante da Fazenda Pública? É comum se encontrar na doutrina a idéia de que contra a de que contra a Fazenda Pública não cabe execução forçada na linha do que já foi exposto precedentemente: natureza do patrimônio público, a separação de poderes... Seria correto, portanto, afirmar que não há execução forçada contra a Fazenda Pública? Não nos parece correte este entendimento por várias razões. Primeiro, porque se a prestação devida ao credor for de entrega de coisa a execução é possível. E esta execução se realizará nos termos em que nos definiu Liebman, isto é, de atuação da sanção secundária. Invade-se a esfera patrimonial do devedor para, contra a sua vontade, satisfazer-se o credor. Desapossa-se a Fazenda Pública sim. Há limites de direito material com relação à Fazenda Pública? Sim, mas é possível a execução contra a Fazenda Pública para desapossamento, para entrega de coisa. (in Direito Processual Público. A Fazenda Pública em Juízo, p. 220).

349 "É cabível execução por título extrajudicial contra a Fazenda Pública" - texto da Súmula 279 do C. STJ. 
Na hipótese de o contribuinte optar pela compensação do seu crédito, não haveria necessidade adicional, restando apenas às administrações fiscais regulamentarem previsões normativas que viabilizem a compensação a partir da sentença arbitral definitiva.

Desse modo, entende-se que a sentença arbitral possui os necessários predicados técnicos e de imparcialidade para reconhecimento do indébito tributário, o que poderia prontamente viabilizar a compensação dos créditos com tributos vincendos, a depender da regulamentação a ser conferida por cada ente tributante. No entanto, para fins de expedição de ofício precatório para pagamento pelo Estado da indenização devida ao contribuinte, entende-se necessária a execução da sentença arbitral nos termos do artigo 730 do CPC, assim como reforma legislativa do CTN para abarcar a possibilidade de o indébito tributário ser reconhecido por sentença arbitral como forma de viabilizar que os valores sejam incluídos em orçamento e entregues aos contribuintes.

\subsection{A extinção do crédito tributário e a sentença arbitral}

O artigo 31 da Lei de Arbitragem estabelece que a sentença arbitral é dotada dos mesmos efeitos da sentença judicial. No entanto, como acima delineado, a sentença arbitral muito embora possua inequívoca efetividade e validade no ordenamento jurídico, não pode ser imposta pelo tribunal arbitral eis que lhe falta poder coercitivo para tanto.

Passemos a analisar os efeitos da sentença arbitral na extinção do crédito tributário, a luz do disposto no art. 31 da Lei de Arbitragem e também com vistas à previsão do artigo 156 do CTN.

Alexandre Monteiro e Leonardo Castro entendem que a sentença arbitral não extinguiria o crédito tributário na medida em que ela reconheceria pagamento, compensação, prescrição, decadência ou outra forma de extinção já tipificada no CTN. ${ }^{350}$

${ }^{350}$ Confira-se;

Assim, vê-se que o juízo arbitral, seja viabilizado por meio de compromisso arbitral ou por cláusula compromissória, é apenas o meio pelo qual será criada a norma individual e concreta obtida pela subsunção do fato à hipótese de incidência, nada mais. A arbitragem, portanto, não cria, majora ou extingue o crédito tributário, mas sim, a decisão proferida pelo juízo arbitral veicula determinado evento vertendo-o em fato jurídico, fazendo com que se desencadeie as consequencias da norma tributária. Esse evento poderá ser o pagamento, a prescrição, a decadência, o parcelamento ou a remissão, por exemplo. Estas sim são as causas jurídicas da extinção do crédito tributário (Direito 
No entanto, como acima aventado, entendemos que a arbitragem poderá tratar da controvérsia tributária anterior ou posterior à constituição do crédito tributário. De fato, nas ocasiões em que a sentença arbitral determinar as condições em que o pagamento será realizado pelo contribuinte, ou mesmo reconhecer o direito à compensação, não terá o condão de extinguir o crédito tributário pois a condição extintiva do crédito será a situação ocorrida e apenas declarada ${ }^{351}$ pela sentença arbitral. Tal como ocorre com semelhantes decisões judiciais ou administrativas.

Por exemplo, suponha-se discussão tributária que visa à desconstituição de determinado auto de infração e imposição de multa lastreada na incorreta valoração do lucro tributável do contribuinte por força de controversas adições e exclusões que tenham sido contabilizadas indevidamente, sob perspectiva da fiscalização. A decisão arbitral poderá ser lançada reconhecendo a parcial validade da autuação fiscal e, desse modo, restaria consignado que o contribuinte tem pagamento a fazer. Feito o pagamento, haverá a extinção do crédito tributário nos termos do artigo 156, I, do CTN. Não havendo adimplemento pelo contribuinte, o fisco poderá constituir seu crédito e, oportunamente, buscar o Poder Judiciário para satisfação do mesmo (mediante inscrição do débito em dívida ativa e ulterior ajuizamento de execução fiscal).

Nesse caso, o fator extintivo do crédito tributário terá sido o pagamento, e não a sentença arbitral que tenha apurado o quantum devido pelo contribuinte.

Em também hipotético caso distinto, a sentença arbitral reconheceria a inexistência de débito sem decretar necessidade de pagamentos adicionais e julgaria extinto o crédito tributário. Nesse caso, a extinção se daria por sentença arbitral irrecorrível, tal como ocorre com a decisão judicial transita em julgado ou mesmo decisão administrativa irrecorrível, ambas aptas a reconhecer o pagamento do débito (nos termos dos incisos IX e X do art. 156 do CTN).

Tributário e arbitragem: uma análise da possibilidade e dos óbices ao juízo arbitral em matéria tributária no Brasil, p.32-33). Justamente por tal razão os autores entendem ser desnecessária a edição de lei complementar para viabilizar a arbitragem tributária.

351 Tratar-se-á de decisão arbitral com cunho declaratório de pagamento, compensação ou outra forma de extinção do crédito tributário. 
Justamente por tal particularidade é que se entende pela necessidade de edição de lei complementar que estabeleça ser a sentença arbitral apta a extinguir o crédito tributário. ${ }^{352}$ Caso contrário, a efetividade buscada na adoção da arbitragem tributária restaria limitada e sua adoção restrita a hipóteses nas quais os efeitos da sentença arbitral não seriam necessários para fins de extinção do crédito tributário.

Vale analisar, afinal, se a redação do art. 31 da Lei da Arbitragem prejudicaria a efetividade de disposição no sentido de que a sentença arbitral seria apta a extinguir o crédito tributário.

Entendemos pela inexistência de prejudicialidade entre a viabilidade de a sentença arbitral vir a extinguir o crédito tributário e a carência do tribunal arbitral para prática de atos coercitivos para cumprimento da decisão. Isso porque a extinção do crédito tributário estará diretamente relacionada à extinção da relação jurídica havida entre fisco e contribuinte. Novo fato a ensejar cobrança por parte do sujeito ativo da relação dependerá de constituição do crédito (CTN, art. 142) para oportunas providências de cunho executivo.

Assim, a carência de poderes para promover a execução forçada da sentença arbitral não afasta a viabilidade de a decisão vir a ser instrumento capaz de extinguir o crédito tributário, desde que irrecorrível e sempre sujeita a intervenção jurisdicional quanto ao mérito decidido nos excepcionais casos aplicáveis.

${ }^{352}$ Cf. II.1.5.2 supra. 


\title{
PARTE III - TRANSAÇÃO
}

\section{CAPÍTULO 1 - TRANSIGIBILIDADE DAS CONTROVÉRSIAS TRIBUTÁRIAS}

\begin{abstract}
Remetendo-nos novamente às observações acerca do estágio dos conflitos tributários no Brasil, cumpre verificar se as controvérsias tributárias são transacionáveis. Para tanto, é preciso avaliar, inicialmente, a natureza da transação e a possibilidade de a mesma ser adotada com relação aos créditos tributários haja vista peculiaridade do objeto. Será feita uma análise da transação a partir do texto do CTN e do crédito tributário frente à natureza da transação, passando-se pela legalidade cerrada em matéria tributária.
\end{abstract}

Será importante fazer uma análise das nuances da transação à luz da Lei de Responsabilidade Fiscal e frente aos novos rumos da tributação participativa, bem como apontamentos sobre os programas de pagamento incentivado de tributos comumente disponibilizados pelos fiscos aos contribuintes para, concluindo-se, avaliarem-se a viabilidade, bem como as vantagens e desvantagens da transação em matéria tributária.

\subsection{Conceito de transação}

Para se avaliar a transação tributária, é inicialmente importante tratar da transigibilidade do crédito tributário, ou seja, é importante aferir se o crédito tributário é um objeto que pode ser transacionado (objeto transacionável).

Para tanto, trazemos breves notas acerca do instituto da transação, a qual se encontra regulada no Código Civil (artigos 840 a 850) e caracteriza-se, substancialmente, por instituto destinado a prevenção ou término de litígios mediante concessões múltiplas das partes envolvidas (art. 840 do Código Civil). 
Candido Rangel Dinamarco ressalta o caráter compositivo e bilateral da transação ao afirmar que "a autocomposição bilateral transparece na transação, que se resolve em mútuas concessões (CC, art. 1.025) e, portanto, participa ao mesmo tempo da natureza da renúncia e da submissão, cada um dos sujeitos acedendo na parcial disposição de seus próprios interesses" ${ }^{353}$ Quanto à definição de litígio, vale mencionar o entendimento do Professor acerca do conflito, a saber, "situação existente entre duas ou mais pessoas ou grupos, caracterizada pela pretensão a um bem ou situação da vida e impossibilidade de obtê-lo - seja porque negada por quem poderia dá-lo, seja porque a lei impõe que só possa ser obtido pela via judicial". ${ }^{354}$

A transação põe fim ao litígio pendente entre as partes presumindo a existência de concessões mútuas, sendo essencial, desse modo, que ambas as partes abram mão de parcela do seu direito em disputa como forma de solucionar a controvérsia. Dito de outro modo, um acerto entre as partes por meio do qual somente uma delas abrirá mão de seus direitos não poderá, nos termos da legislação civil, ser qualificada como transação. É necessário que haja solução de um conflito previamente estabelecido entre as partes - o que não prescinde, por certo, da existência de demanda judicial em curso.

No entanto, o artigo 841 do Código Civil estabelece que a transação somente pode operar-se quanto a direitos patrimoniais de caráter privado. Teria tal disposição o condão de afastar por completo a possibilidade de haver transação tributária na medida em que o crédito tributário não se encontra na esfera dos direitos de caráter privado $?^{355}$

A definição do Código Civil, no nosso entender, não afasta a possibilidade de o poder público transigir com relação a direitos da esfera pública, o que se justifica sobretudo diante da nova concepção de interesse público e também por força das atuais e complexas relações existentes entre o poder público e os administrados. A própria viabilidade de a administração pública contratar com particulares denota ter havido

\footnotetext{
${ }^{353}$ Cândido Rangel Dinamarco, Instituições..., vol. I, p. 120.

${ }^{354}$ Importante destacar que a definição de conflito acima conclui pela existência de conflitos que somente poderão ser solucionados na via judicial, remetendo-se à definição do direito processual civil como técnica de solução imperativa de conflitos" (DINAMARCO, Cândido Rangel, Instituições..., vol. I, p. 117, referindose ao teor da p. 35). A definição de processo civil não guarda compatibilidade com os termos do presente estudo, conforme exposto no item I.2.3 e I.3.1 acima. Não se nega, no entanto, que há conflitos que somente poderão ser solucionados em juízo estatal, como por exemplo aqueles que envolvam incapazes.

${ }^{355}$ Veja, nesse sentido, as reflexões acerca da natureza do crédito tributário (cf. I.2.3 acima).
} 
mitigação da tradicional concepção de direito público indisponível, como amplamente abordado acima. ${ }^{356}$

Já não é recente no nosso direito a possibilidade de o poder público transacionar com relações a direitos da esfera pública. Vide, nesse sentido, ementa de julgado de 2007 que trata expressamente da possibilidade de o poder público renunciar a valores ao firmar transação extrajudicial:

\begin{abstract}
ADMINISTRATIVO. TERMO DE RESOLUÇÃO DE CONTRATO CELEBRADO ENTRE O INCRA E EMPRESA PARTICULAR. QUITAÇÃO POR VALOR QUE A PARTE CREDORA REPUTA INFERIOR AO DEVIDO. NATUREZA DE TRANSAÇÃO. IRRETRATABILIDADE. ACESSO AO PODER JUDICIÁRIO. PRESERVAÇÃO. MORALIDADE ADMINISTRATIVA. OBSERVÂNCIA. DEMORA NO PAGAMENTO. COAÇÃO NÃO CARACTERIZADA. 1. Qualifica-se como transação extrajudicial destinada a prevenir litígios (art. 1.025, CC/16) o "Termo de Resolução de Contrato" por meio do qual ambas as partes acordam quanto à quitação total do débito por quantia que a parte credora reputa inferior à devida. 2. Tratando-se de transação, não pode qualquer das partes dela se retratar unilateralmente (art. 1.030, CC/16), sob pena de ofensa ao princípio da obrigatoriedade das convenções (pacta sunt servanda). 3. A cláusula que materializa a quitação do débito, com declaração de que a contratada nada mais tem a receber administrativa ou judicialmente, não atenta contra o princípio da acessibilidade ao Poder Judiciário (art. $5^{\circ}, X X X V$, CF/88). 4. Não viola o princípio da moralidade administrativa a transação extrajudicial que põe fim a controvérsia envolvendo pessoa jurídica de direito público mediante pagamento de valor reputado devido por seus órgãos técnicos. 5. O eventual pagamento de quantia inferior à devida é inerente ao instituto da transação, não implicando ofensa ao princípio da moralidade administrativa, sob pena de se considerar ilegítima qualquer transação celebrada pelo Poder Público. 6. O simples atraso no pagamento de débito, ainda que submeta o credor a dificuldades financeiras, não se qualifica como coação. 7. Apelação não provida.". ${ }^{357}$
\end{abstract}

Há entendimento jurisprudencial que inclusive salienta serem necessários cuidados adicionais a serem avaliados nos casos em que o poder público transacione, como por exemplo a titularidade dos direitos transacionados e legalidade. Confira-se trechos de ementa de interessante julgado:

"(...) Em Direito Administrativo, a transação é possível, mas com limites bem conhecidos. Antes de nada, é preciso levantar uma dificuldade com relação aos efeitos da transação, dificuldade que a Apelada não foi capaz de perceber: ninguém pode transacionar um direito que não lhe pertence. Todos os direitos têm seus respectivos pressupostos. Por isso, quem tomá-los como objeto de consideração bem fará em primeiramente investigar a presença desses requisitos. Quando se diz, que as partes podem pôr termo ao processo mediante recíprocas concessões, isso tem como pressuposto que elas sejam as reais titulares dos direitos transacionados. - Todos sabem que um dos principais alicerces do nosso sistema encontra-se no princípio, expresso no art. $6^{\circ}$ do CPC, de que ninguém pode, em nome próprio, litigar direito alheio. Ora, isso também vale, com muito mais razão, para os acordos pelos quais as partes, concedendo direitos e deveres, terminam um litígio, eliminando a eventual incerteza de uma relação jurídica. Ao negar que alguém possa pleitear, em seu nome, direito de outrem, a lei também fixou o correlato princípio lógico de que somente o titular pode transacioná-lo. É que ninguém pode, em nome próprio, dispor de direito alheio.

\footnotetext{
${ }^{356}$ Vide análise mais pormenorizada da questão no item I.2.2 acima.

357 TRF 1, AC 200001000298180, Rel. JUIZ FEDERAL MARCELO ALBERNAZ, DJ DATA:05/02/2007 PAGINA:106.
} 
(...)

Não é por outro motivo que, depois de chancelar a sua natureza contratual, Orlando Gomes não perde a oportunidade de realçar que "a transação é res inter alios acta. Não aproveita, nem prejudica, senão aos que nela intervieram. Por outras palavras, obriga exclusivamente as partes. Terceiros não podem ser prejudicados com sua realização".

(...)

Os contratos firmados com o Poder Público apresentam dupla face: a do direito e a do dever. Ao lado das obrigações neles contraídas pelos particulares, há o direito subjetivo público, decorrente do principio da igualdade, que faculta a todos, uma vez atendidos os pressupostos condicionantes em legislação (Lei 8.666), a possibilidade de contratar com o Poder Público. Se todos são iguais, perante a lei (CF, art. $5^{\circ}$, caput), todos também haverão de sê-lo em face da Administração Pública que, por força da Constituição (art. 37, inciso XXI) e da Lei de Licitações (art. $3^{\circ}$ ), a todos assegura o igual direito de com ela pactuar. - Isso significa que ninguém pode ser alijado do rol dos possíveis licitantes ou dos efetivos contratados sem que haja um fundamento legal para tanto. Como se percebe, é sobretudo como titular de um direito subjetivo público que os licitantes e os contratados assumem o seu posto no âmbito da Lei 8.666. Pois bem, direito subjetivo público quer dizer faculdade protegida pela ordem jurídica com todos os meios possíveis e idôneos, cujo reconhecimento só pode ser negado quando o próprio sistema assim o prescrever. Mas não é isso o que se observa no caso dos autos. Uma vez que se trata de um autêntico contrato, falta àquela transação o essencial status de lei que lhe permitiria, então, arredar todas as Cooperativas de Trabalho do universo dos virtuais licitantes e dos atuais contratados. (...)"..

Especificamente na seara tributária, entendendo ser programa de recuperação fiscal modalidade de transação, ${ }^{359}$ confira-se entendimento jurisprudencial que admite não só a disposição parcial do crédito tributário, mas salienta a direta e imediata interferência da legalidade:

DIREITO TRIBUTÁRIO. PARCELAMENTO. REFIS. ADESÃO INTEMPESTIVA. PEDIDO DE INCLUSÃO FORA DE PRAZO. IMPOSSIBILIDADE. LEGALIDADE TRIBUTÁRIA. PRINCÍPIO DA ISONOMIA. 1 - Postulação de inclusão da parte autora no REFIS. Lide decorrente de pedido intentado fora do prazo legal em sede administrativa. 2 - O parcelamento tributário é forma de transação administrativa e, portanto, acarreta disposição parcial de erário público. Sujeita-se, assim, ao princípio da estrita legalidade, devendo ser obedecidos rigorosamente cada um dos aspectos previstos na lei. Não possui, pois, o administrador público o poder discricionário de disposição de tais critérios, e muito menos cabe ao magistrado atuar como legislador positivo. 3 Inexistência de ofensa ao princípio da isonomia, que só restaria violado na hipótese de concessão individual de novo prazo, presentemente. 4 - Cumpre relevar que o prazo do REFIS, foi prorrogado pela Lei 10.002/00, por mais noventa dias, dificilmente havendo motivo a justificar a omissão durante tanto tempo. ${ }^{360}$

Resta, assim, averiguar se a transação poderá se dar em se tratando de crédito tributário, na medida em que não basta tratar-se de transação firmada pelo poder público: há particularidades do objeto da transação tributária a serem averiguadas.

${ }^{358}$ TRF da 4a Região. AMS 200471000183773. Rel. CARLOS EDUARDO THOMPSON FLORES LENZ. DJ 23/08/2006 PÁGINA: 1107.

${ }^{359}$ Sobre a natureza de tais programas, vide infra III.1.6.

${ }^{360}$ TRF 4. AC 200170000265282. Rel. ARTUR CÉSAR DE SOUZA. DJ 02/08/2006 PÁGINA: 303. 


\subsection{O tributo e a transação}

Para transigir, o administrador representante do fisco deverá ter poderes para renunciar a parcela do crédito tributário. A indisponibilidade do crédito tributário pode ser mitigada na medida em que haja lei autorizativa da sua cessão, o que se conclui sobretudo diante da disposição expressa no sentido de que a lei poderá dispor sobre a transação tributária (artigos 156 e 171 do CTN). ${ }^{361}$

Muitos institutos adaptam-se da esfera privada para a pública e, a despeito de não perderem suas características essenciais, adquirem aspectos que viabilizam sua adoção nas relações envolvendo entes públicos. ${ }^{362}$ Haverá, por certo, diferenças de natureza jurídica da transação cível e da transação administrativa, o que certamente alcançará as transações tributárias. Tanto é assim que o Projeto de Lei 5082/2009, que trata da transação tributária, menciona expressamente os deveres de veracidade, de lealdade, de boa-fé, de confiança, de colaboração e de celeridade, como formas de conferir validade à transação.

Trazendo comparação entre a transação tributária e a transação civil, César García Novoa $^{363}$ destaca que o fato de os acordos terem sua origem em obrigação privada não traz qualquer consequência ao direito tributário na medida em que o acordo tendo por objeto o tributo decorrerá das normas fiscais aplicáveis.

\footnotetext{
${ }^{361}$ Vale destacar caso concreto no qual o Tribunal de Justiça do Estado do Rio Grande do Sul desconsiderou acordo firmado entre o fisco e contribuinte, homologado judicialmente na instância ordinária, por entender que seria "inadmissivel transação em sede de mandado de segurança, o objeto da transação extrapolaria o objeto do writ, não seria lícito compor acerca da incidência ou não de tributo, somente quanto a direitos patrimoniais de caráter privado se admite transacionar" (Embargos de Declaração em Embargos de Declaração em Apelação Cível em Mandado de Segurança 2006.032093-1/0002.01).

${ }^{362}$ Nesse sentido, vale destacar o entendimento do STJ no sentido de que em situações excepcionais o poder público pode transigir quanto a direitos difusos e coletivos. Confira-se:

PROCESSO CIVIL - ACÃO CIVIL PÚBLICA POR DANO AMBIENTAL - AJUSTAMENTO DE CONDUTA - TRANSAÇÃO DO MINISTÉRIO PÚBLICO - POSSIBILIDADE.

1. A regra geral é de não serem passíveis de transação os direitos difusos.

2. Quando se tratar de direitos difusos que importem obrigação de fazer ou não fazer deve-se dar tratamento distinto, possibilitando dar à controvérsia a melhor solução na composição do dano, quando impossível o retorno ao status quo ante.

3. A admissibilidade de transação de direitos difusos é exceção à regra. 4. Recurso especial improvido. (RECURSO ESPECIAL $\mathrm{N}^{\circ}$ 299.400. $2^{\text {a }}$ Turma. Rel. MINISTRO FRANCISCO PEÇANHA MARTINS. J. $1^{\circ}$ de junho de 2006).

${ }^{363}$ Mecanismos alternativos para la resolución de controversias tributarias. Su introducion em el derecho español, p. 94.
} 
Citando o sistema francês, José Luis Esquivel trata da diferença de fundamentação legal a amparar referidas possibilidades de transação nas esferas pública e privada, na medida em que a transação administrativa não necessariamente deverá pressupor concessões recíprocas e, ademais, salienta que nas negociações firmadas pela administração pública não há paridade entre as partes, mas sim superioridade da administração e o aniquilamento de aspectos essenciais da transação. ${ }^{364} \mathrm{O}$ autor conclui afirmando "a transacção administrativa está para a transacção de direito privado assim como o contrato administrativo está para o contrato de direito privado". 365

Interessante, nesse aspecto, ressaltar os institutos italianos ${ }^{366}$ que permitem acordos entre o fisco e o contribuinte, sobretudo em razão do entendimento da doutrina italiana no sentido de que a transação que ocorre no procedimento de conciliação não representa, para a administração pública, renúncia ao crédito tributário, ${ }^{367}$ mas sim renúncia a uma pretensão, não sendo correto, portanto, afirmar que a administração, ao transacionar, abre mão da obrigação tributária. ${ }^{368}$

Também pela viabilidade de o poder público transacionar, Rodolfo de Camargo Mancuso $^{369}$ esclarece que a expressão direitos indisponíveis participa de uma gama de conceitos vagos ou indeterminados, salientando que "já é tempo de essa expressão ser tecnicamente analisada, a fim de dar-lhe sua real dimensão”. O professor traz argumentos

\footnotetext{
${ }^{364}$ Confira-se: “somos da opiniao que apenas se pode falar em transacção administrativa quantanto figura distinta da transacção de direito privado, não no que se refere ao conceito base de transacção de raiz juscivilista, enquanto contrato pelo qual as partes previnem ou terminam um litígio mediante recíprocas concessões, que é válido no campo do Direito Adminsitrativo, mas na medida em que a transacção pode, consubstanciar um contrato administrativo adjectivo e, nessa medida, ficar sujeita a um regime material $e$ processual diferente das transacções celebradas, ainda que pela Administração Pública, ao abrido do Direito Privado." (Os contratos administrativos e arbitragem, p. 94-95).

${ }^{365}$ Os contratos administrativos e arbitragem, P. 107.

${ }^{366}$ Heleno Taveira Torres traz uma análise do accertamento com adesione italiano em Transação, arbitragem e conciliação judicial como medidas alternativas para resolução de conflitos entre administração e contribuintes - simplificação e eficiência administrativa, p. 57.

${ }^{367}$ No sentido de que na conciliação não há renúncia ao crédito tributário, ver Gaspare Falsitta, Manualle de Diritto Tributario, p. 350. O Autor defende, no entanto, a prevalência da indisponibilidade do crédito tributário, o que não seria ofendido pela conciliação na medida em que não se trata de crédito já constituído, pois ocorre na fase de denúncia.

Confira-se: "Né questa tesi può contradderra invocando gli istituti del concordato tributário e della conciliazione giudiciale delle liti tributarie di recente reintrodutte su vasta scala nel sistema tributário del nostro Paese. La scelte sottese al potere di definizione concordatária vengono adottate in uma fase del rapporto in cui Il credito tributário è incerto sai nella sua esistenza sai nel suo ammontade ed è sottoposto Allá spada di Damocle di um contenzioso dall'esito dubbio.Parlare di rinuncia al credito o di atti di disposizione dello stesso è perciò errato. ".

${ }^{368}$ Nesse sentido, FERRARA e BELLÈ, Diritto Tributatio Processuale, p. 159.

${ }^{369}$ O plano piloto de conciliação..., p. 874.
} 
para justificar a transação praticada pelo poder público na medida em que "os termos 'indisponibilidade' e 'transação' não são incompossíveis", ${ }^{370}$ tais como a previsão de acordo em ações que tratam de danos ao ecossistema (cf. artigo $7^{\circ}$ da Lei n. 7.661/1998). Após fazer a pertinente análise, conclui o autor que na medida em que o poder público é capaz de solucionar internamente seus próprios conflitos, seria plenamente viável a solução de demandas judiciais por conciliação. ${ }^{371}$

Ou seja, entende-se por mitigada a disposição do Código Civil no sentido de que a transação não poderia se operar diante da atual realidade do direito público, na medida em que há direitos patrimoniais públicos passíveis de ser objeto de negociação entre poder público e particular. Como visto acima, há vasto entendimento jurisprudencial a respaldar essa conclusão.

Especialmente quanto ao crédito tributário, vale analisar a questão diante da expressa autorização legislativa para que seja instaurada a transação quanto à controvérsia tributária, contida no artigo 171 do CTN. Assim, havendo previsão legal autorizativa, parece perfeitamente possível que a controvérsia tributária seja solucionada mediante concessões mútuas. É o que se investigará a seguir.

\subsection{Transação, o CTN e o crédito tributário como objeto transacionável}

$\mathrm{O}$ artigo $3^{\circ}$ do $\mathrm{CTN}$, que define tributo como sendo "toda prestação pecuniária compulsória, em moeda ou cujo valor nela se possa exprimir, que não constitua sanção de ato ilícito, instituída em lei e cobrada mediante atividade administrativa plenamente vinculada”, é apontado por muitos como impeditivo da transação tributária. No entanto, o próprio CTN, nos artigos 156 e 171, trata da possibilidade de fisco e contribuinte transigirem quanto ao crédito tributário. Cumpre avaliar, nesse cenário, se o Código Tributário Nacional ou mesmo a Constituição Federal trariam, ou não, dispositivo impeditivo da transação entre fisco e contribuinte em se tratando de controvérsia tributária.

${ }^{370}$ Cit., p. 877.

${ }^{371}$ Cit., p. 880. 
Para Eurico Santi, a transação seria inviável, dentre outras razões, por alterar o conceito de tributo insculpido no art. $3^{\circ}$ do CTN na medida em que o caráter vinculado da cobrança afastaria qualquer margem de transigibilidade relativa ao crédito tributário. ${ }^{372}$

Hugo de Brito Machado ${ }^{373}$ ao avaliar a questão entendeu que aqueles contrários à possibilidade de transação tributária apontam incompatibilidade entre os artigos $3^{\circ}$ e 171 do CTN, na medida em que o legislador permite a transação a despeito de conferir ao tributo qualidade de ser cobrado mediante atividade administrativa plenamente vinculada. ${ }^{374} \mathrm{O}$ autor salienta que a indisponibilidade do crédito tributário aplica-se ao agente público, mas não ao Estado ${ }^{375}$ na medida em que por vezes poderá ser mais vantajoso ao interesse público transacionar quanto ao crédito tributário do que perpetrar cobrança absolutamente indevida. ${ }^{376}$

Como afirma o Professor, "o caráter plenamente vinculado da atividade administrativa somente será contrariado se a lei ordinária atribuir às autoridades lançadoras em geral, ou às autoridades que em geral presentam (sic) a Fazenda Pública em juízo, competência para transações. (...) a lei ordinária deve estabelecer as condições em que pode ser feita a transação com tal objetividade que restará afastada a discricionariedade,. 377

\footnotetext{
${ }^{372}$ Para o autor, a transação ignora os seguintes aspectos do tributo: “(i) não há opção quanto à cobrança ou não do crédito; (ii) não há opção quanto ao procedimento e (iii) não há opção quanto ao conteúdo do crédito tributário objeto da atividade administrativa." (Eurico Marcos Diniz de Santi, Transação e arbitragem no direito tributário: paranoia ou mistificação?, p. 167-190).

${ }^{373}$ In Transação e arbitragem no âmbito tributário, p. 115.

${ }^{374}$ Transação e arbitragem no âmbito tributário., p. 113.

${ }^{375}$ Acerca da possibilidade de haver disposição pelo Estado do crédito tributário, Luiz Dias Martins Filho e Luís Adams salientam que "os interesses da Fazenda Pública, por representarem o que a doutrina denominou de interesses públicos secundários, podem ser, sim, nos estritos limites legais, objeto de transação tributária, prevista em dispositivos do CTN (art. 156, III, e art. 171)" (In, A transação no Código Tributário Nacional (CTN) e as novas propostas normativas de lei autorizadora., p. 31).

${ }^{376}$ Confira-se:

para aceitarmos a transação no Direito Tributário, realmente, basta entendermos que o tributo, como os bens públicos em geral, é patrimônio do Estado. Indisponível na atividade administrativa, no sentido de que na prática ordinária dos atos administrativos a autoridade dele não dispõe. Disponível, porém, para o Estado, no sentido de que eles, titular do patrimônio, dele pode normalmente dispor, desde que atuando pelos meios adequados para a proteção do interesse público, vale dizer, atuando pela via legislativa, e para a realização dos fins públicos.

Em algumas situações é mais conveniente para o interesse público transigir e extinguir o litígio, do que levar este até a última instância, com a possibilidade de restar a Fazenda Pública afinal vencida. Daí a possibilidade de transação. Em casos estabelecidos na lei, naturalmente, e realizada pela autoridade à qual a lei atribuiu especial competência para esse fim (In Transação e arbitragem no âmbito tributário, p. 115).

${ }^{377}$ A transação no direito tributário, p. 64-65.
} 
Heleno Taveira Torres ${ }^{378}$ salienta que sendo observada a legalidade, não há óbice para que haja solução de controvérsia tributária mediante transação, na medida em que a definição do artigo $3^{\circ}$ do CTN em momento algum prescreveu impeditivo à disposição legal do crédito tributário. Na mesma linha é o entendimento de Fabio Artigas Grillo, para quem "em face da indisponibilidade (...) da receita tributária concretizada no procedimento legal de lançamento tributário, o dever de pagar o tributo e exercício de seu direito de percepção pelo Fisco, somente pode ser objeto de disposição quando houver deliberação legal específica nesse sentido". 379

Não parece que o CTN, sem dispor expressamente sobre qualquer aspecto que pudesse impedir que a transação se operasse quanto ao crédito tributário, possa ser apontado como inviabilizador do instituto, sobretudo em razão da expressa menção à transação como condição extintiva do crédito tributário (artigo 156) e também sobre a adoção da transação, a ser regulamentada em lei própria, nos termos do artigo 171 do Codex.

Quanto à letra do artigo $3^{\circ}$ do CTN, a redação parece esclarecedora no sentido de que as atividades de constituição, cobrança, e arrecadação do tributo seriam indisponíveis, não trazendo qualquer menção à indisponibilidade do crédito tributário per si.

Também não se encontra no texto constitucional "qualquer dispositivo" que constitua óbice à transação tributária (ou mesmo a qualquer espécie de solução convencional), na linha do entendimento já manifestado por Fabio Artigas Grillo. ${ }^{380}$

\footnotetext{
${ }^{378}$ Como afirma o Professor, "Só a ignorância absoluta do conceito de tributo pode levar ao equívoco, de plano afastado, segundo o qual o tributo não poderia se submeter a um procedimento de extinção de créditos fundado na solução de litígios, por recíprocas concessões, à luz do art. $3^{\circ}$, do CTN, quando esta mesma disposição prescreve que a "legalidade" determinará as condições da existência e da vinculação das formas de extinção. Ademais, esta prescrição nunca foi a definição de tributo - formalismo esdrúxulo que não se entende - como ressalta a doutrina mais relevante. E, por fim, sobre a extinção do crédito, é a própria Constituição que estabelece a Lei Complementar como meio para instituir suas modalidades (art. 146, III, " $b$ ")" (In Princípios da segurança jurídica e transação em matéria tributária. Os limites da revisão administrativa dos acordos tributários,p. 308).

${ }^{379}$ Transação e justiça tributária, p. 186.

${ }^{380}$ Transação e justiça tributária, p. 185.
} 
Ademais, é assente na doutrina que entende viável a transação tributária que a solução da controvérsia mediante acordo entre fisco e contribuinte não acarreta, tecnicamente, em disposição ou renúncia ao crédito tributário na medida em que se tratará de solução mais adequada ao conflito e, portanto, mais benéfica também ao erário. Nesse sentido, vale destacar a conclusão de Fabio Artigas Grillo no sentido de que a transação necessariamente prescinde o "sacrifício por parte dos sujeitos da relação jurídica". 381

Na Itália, Ferrara e Belle ${ }^{382}$ ressaltam que a norma de conciliação tributária não considerou relevante a indisponibilidade do crédito tributário, priorizando a possibilidade e viabilidade de a administração pública solucionar a lide pendente com o abandono total ou parcial do crédito tributário.

Enquanto prevalecia na Itália a concepção de indisponibilidade absoluta da obrigação tributária, ${ }^{383}$ não era viável a ocorrência conciliação judicial. ${ }^{384} \mathrm{Com}$ o advento do Decreto Legislativo 546/92 instaurou-se a conciliação e a partir de norma de $1994^{385}$ aplicou-se a forma encerramento de lide fiscal pendente no âmbito judicial. Atualmente, a conciliação pode ser judicial ou mesmo extrajudicial (mediante acordo a ser ulteriormente homologado pelo juízo tributário). ${ }^{386}$

381 Transação e justiça tributária, p. 200.

${ }^{382}$ Op cit., p. 159.

${ }^{383}$ Nesse sentido, "La conciliazione era rimasta tradizionalmente estranea al processo tributario nona vendo trovato applicazione né prima né dopo la riforma degli anno settanta dello scorso secolo. Ad essa, infantii, se lega logicamente la disposizione dei diritto dedotti nella lite ed Il principio di indisponibilità dell'obbrigazione tributaria era stato considerato ostacolo insuperable Allá sua ittilizzazione” (FERRARA, Frabco Batistoni e BELLÈ, Brunella, Diritto tributatio processuale, p.154).

${ }^{384}$ A legislação italiana prevê as seguintes hipóteses para se evitar ou resolver os conflitos tributários: autotutela (l'autotutela), por meio da qual se aponta um erro da administração tributária, o qual é prontamente corrigido; aquiescência (l'acquiescenza), ou aceitação do ato como tributável,que concede redução na penalidade a ser paga pelo contribuinte; conciliação judicial (la conciliazionegiudiziale), que põe fim num contencioso já iniciado e confere desconto ao contribuinte para pagamento do tributo; avaliação com adesão (l'accertamentoconadesione), por meio do qual o contribuinte concorda em dever o imposto e obtém desconto da penalidade; e o convite ao contraditório e ao processo verbal de contatação (l'adesioneall'invito al "contraddittorio" e ai "processiverbali di constatazione"), no qual se define a situação fiscal do contribuinte antes de qualquer procedimento investigativo e concede descontos/vantagens ao contribuinte para liquidar o crédito tributário (conforme anuário do contribuinte - Annuariodel contribuinte $\quad 2012 \quad-, \quad$ disponível em http://www.agenziaentrate.gov.it/wps/wcm/connect/97f566004bb1f43c94bbf5d94f8d55f4/annuario2012+part e+VIII+online.pdf?MOD=AJPERES\&amp;CACHEID=97f566004bb1f43c94bbf5d94f8d55f4), acesso em 09.02.2013.

385 Decreto-Lei 452, de 18 de Julio de 1994 tratava do encerramento de uma lide fiscal pendente ("chiusiradellelitifiscalipendenti").

${ }^{386}$ Cf. DE LUCA, Gianni, Compendio di Diritto Tributario, p. 135. 
$\mathrm{Na}$ doutrina italiana, a transação tributária que ocorre no procedimento de conciliação não representa, para a administração pública, renúncia ao crédito tributário, ${ }^{387}$ mas sim renúncia a uma pretensão, não sendo correto, portanto, afirmar que a administração, ao transacionar, abre mão da obrigação tributária. ${ }^{388}$

A conciliação judicial, na medida em que voltada a eliminar total ou parcialmente a controvérsia, às vezes se qualifica como verdadeira transação na medida em que há concessões mútuas que, a seu turno, representam o reconhecimento da existência de direito da outra parte. ${ }^{389}$ Com a conciliação o contribuinte obterá, por exemplo, desconto no pagamento de penalidades e se livrará dos custos do processo; a seu turno, a administração pública verá resolvida a lide, em caráter definitivo, e receberá o prontamente os valores definidos.

Como bem salienta Heleno Taveira Torres, a solução da controvérsia fiscal mediante transação, em verdade, reforçará o princípio da verdade material ao proporcionar uma solução mais célere, justa e econômica "para controvérsia que poderia ocupar lustros em pendências administrativas ou judiciais". 390

Justamente por entender que a transação não corresponde a favor fiscal, o Pleno do Supremo Tribunal Federal, quando do julgamento da Medida Cautelar em Ação Direta de Inconstitucionalidade No. 2.401-5 $5^{391}$ entendeu viável a transação perpetrada pela legislação tributária analisada na ocasião. Ou seja, aliando-se a disposição do artigo 171 do CTN à

\footnotetext{
${ }^{387}$ No sentido de que na conciliação não há renúncia ao crédito tributário, ver Gaspare Falsitta, op, cit., p. 350. O Autor defende, no entanto, a prevalência da indisponibilidade do crédito tributário, o que não seria ofendido pela conciliação na medida em que não se trata de crédito já constituído, pois ocorre na fase de denúncia.

Confira-se: "Né questa tesi può contradderra invocando gli istituti del concordato tributário e della conciliazione giudiciale delle liti tributarie di recente reintrodutte su vasta scala nel sistema tributário del nostro Paese. La scelte sottese al potere di definizione concordatária vengono adottate in uma fase del rapporto in cui Il credito tributário è incerto sai nella sua esistenza sai nel suo ammontade ed è sottoposto Allá spada di Damocle di um contenzioso dall'esito dubbio.Parlare di rinuncia al credito o di atti di disposizione dello stesso è perciò errato.".

${ }^{388}$ Nesse sentido, FERRARA e BELLE, op cit., p. 159.

389 Confira-se o original: "la concilizazione se atteggia como strumento tendente all'eliminazione, totale ou parziale, della controvérsia in essere, suscetibilie, di volta in volta, di esprimere una transazione, ove comporti reciproche concessioni innovatrici, ma anche di risolversi in um riconoscimento del diritto altrui" (FERRARA e BELLÈ, op cit., p. 157-158).

${ }^{390}$ In Princípios da segurança jurídica e transação em matéria tributária. Os limites da revisão administrativa dos acordos tributários..., p. 307.

${ }^{391}$ Relator Min. Carlos Britto, j. 06.11.2002.
} 
expressa previsão legal que traga as condições, parâmetros e aspectos da transação, a mesma será viável.

A jurisprudência salienta que a possibilidade de transação entre fisco e contribuinte contribuirá para a confirmação do interesse público, sobretudo nas hipóteses em que a manutenção do litígio traria mais gravames ao Estado do que sua pronta solução, ainda que mediante acordo no sentido de reconhecer que parte do montante em discussão não é, de fato, devido. ${ }^{392}$

Como se vê, a possibilidade de fisco e contribuinte transigirem para fins de solução da controvérsia tributária não só estimularia o diálogo entre os sujeitos envolvidos na relação jurídico-tributária, mas também permitiria que a tributação se dê de forma participativa, o que por certo conferirá segurança, confiabilidade e também reciprocidade nas relações tributárias, as quais são, como já amplamente exposto no decorrer do estudo, complexas e nada cordiais sob a perspectiva do contribuinte. Tal aspecto é verificado, conforme ensina Caio Yuri Araújo Morais, na solução judicial das controvérsias tributárias e será aprimorado na medida em que se regulamente a transação tributária. ${ }^{393}$

${ }^{392}$ Nesse sentido, vale transcrever ementa de julgado oriundo do STF:

Poder Público. Transação. Validade. Em regra, os bens e o interesse público são indisponíveis, porque pertencem à coletividade. É, por isso, o Administrador, mero gestor da coisa pública, não tem disponibilidade sobre os interesses confiados à sua guarda e realização. Todavia, há casos em que o princípio da indisponibilidade do interesse público deve ser atenuado, mormente quando se tem em vista que a solução adotada pela Administração é a que melhor atenderá à ultimação deste interesse.

Assim, tendo o acórdão recorrido concluído pela não onerosidade do acordo celebrado, decidir de forma diversa implicaria o reexame da matéria fático-probatória, o que é vedado nesta instancia recursal ( Súm. 279/STF).

Recurso extraordinário não conhecido. (STF. RE 253.885-0 MG. Primeira Turma. J. 04.06.2002. DJ de 21.06.2002. Rel. Min. Ellen Gracie).

Vale transcrever trecho do voto da Min. Relatora sobre a preponderância do interesse público verificada na transação analisada: "Por outro lado, o acórdão recorrido, para concluir pela validade da transação firmada entre a Municipalidade e as recorridas, considerou que, no caso, o acordo serviu a uma mais rápida e efetiva consecução do interesse público, não havendo, assim, que se falar em ofensa ao art.37 da Constituição Federal".

${ }^{393}$ Confira-se:

Assim, a transação em matéria tributária oferece maior segurança jurídica tanto ao contribuinte quanto à Administração, pois substitui a atuação unilateral e discricionária da Administração por um ato administrativo participado, o qual permite a delimitação do conceito indeterminado segundo os dados concretos aportados por ambas as partes. Nesses casos, a precisão do conceito indeterminado significará o exercício de uma faculdade restrita ao âmbito puramente cognoscitivo e interpretativo em relação aos elementos fáticos na aplicação da lei. Ora, se já era possível exercer um controle jurisdicional para adequar a inicial aplicação do conceito jurídico indeterminado que realizou a Administração e processar sua adequação ao caso concreto, nada obsta que essa tutela jurisdicional seja substituída por uma solução pactuada (In Transação e 
Nesse sentido, vale destacar o entendimento de Rodolfo de Camargo Mancuso sobre a inexistência de monopólio do Judiciário para solucionar controvérsias tributárias, sobretudo em razão de ser preferencial ao interesse público, em determinados casos, que haja solução da controvérsia mediante transação. ${ }^{394}$

E de forma a corroborar todo o aqui exposto, não há prescrita no CTN óbice à transação tributária; o artigo 171 do Codex, de fato, traz expressa previsão de viabilidade do instituto. Vale destacar que os fiscos regulamentam constantemente programas de pagamento incentivado de tributos, com verdadeiro caráter transacional, ${ }^{395}$ o que torna não só a transação viável, mas também presente na realidade da relação entre físco e contribuinte.

Destaca-se, a esse respeito, entendimento jurisprudencial do Tribunal Regional Federal da $1^{\text {a }}$ Região ${ }^{396}$ no sentido de que o artigo 141 do Código Tributário Nacional, ao estabelecer que "o crédito tributário regularmente constituído somente se modifica ou extingue, ou tem sua exigibilidade suspensa ou excluída, nos casos previstos nesta Lei, fora dos quais não podem ser dispensadas, sob pena de responsabilidade funcional na forma da lei, a sua efetivação ou as respectivas garantias” obstaria a transação. Se a lei tratar da transação, dos seus limites e condições, não haverá margem para invalidação do

arbitragem em matéria tributária: a experiência estrangeira e sua aplicabilidade ao direito brasileiro, p. 483-503).

394 Assim salienta o Professor:

o propósito da União em cobrar sua dívida ativa através de seus próprios quadros administrativos não ofende, direta ou obliquamente, o art. $5^{\circ}, X X X V$, da $C F$, nem se choca com o sistema como um todo, porque, conforme tese desenvolvida ao longo do trabalho ora introduzido, tal dispositivo não firma qualquer sorte de monopólio em prol da Justiça estatal, nem tampouco obriga as pessoas físicas ou jurídicas, de direito privado ou público, a submeterem seus pretensões a um órgão judicial, certo ainda que a obrigação tributária integra o âmbito do interesse fazendário (ou interesse público secundário), passível, portanto, de ser transacionado (MANCUSO, A resolução dos conflitos e a função judicial no contemporâneo Estado de Direito (nota introdutória), p. 15-16).

${ }^{395}$ Vide especificamente item III.1.6.

${ }^{396}$ Confira-se, por todas, trechos de ementa de julgado do TRF1:

(...) DIREITO INDISPONÍVEL. ART. 144 DO CTN. TRANSAÇÃO. INADMISSIBILIDADE. AUSÊNCIA DE UMA DAS PARTES NA AUDIENCIA. NULIDADE AFASTADA. 1. Ao Poder Judiciário não está vedada pela Constituição Federal a implementação de alternativas para solução dos conflitos de forma rápida e consensual, conforme o princípio da eficiência (art. 37). 2. Execução fiscal de anuidade devida a conselho profissional, de natureza tributária, constitui direito indisponível nos termos do art. 141 do CTN, e, portanto, inadmissível a transação. 3. A não realização de audiência de conciliação, por ausência da parte autora, não importa em nulidade do processo, uma vez que as partes podem transigir a qualquer momento. 4. Apelação a que se dá provimento. (TRF 1. Rel. DESEMBARGADORA FEDERAL MARIA DO CARMO CARDOSO. $8^{\mathrm{a}}$ Turma. e-DJF1 DATA:23/03/2012 PAGINA:1324). 
ato nos termos do mencionado dispositivo. E, como visto, a legalidade e a tipicidade são intrínsecas a toda e qualquer relação entre fisco e contribuinte, o que por certo não seria ignorado em se verificando a transação.

Desse modo, não se entende haver qualquer vedação no Código Tributário Nacional ou mesmo na natureza do crédito tributário à solução das controvérsias tributárias por transação, desde que haja regulamentação e fundamentação legal, em respeito à legalidade e tipicidade cerrada tributária (artigo 150, I da Constituição Federal), como se passa a observar. Em sendo observados tais ditames, como passaremos a avaliar, demonstraremos que também na Constituição Federal não há óbice à transação tributária.

\subsection{Legalidade}

A legalidade é apontada tanto pela doutrina como pelo Código Tributário Nacional como elemento essencial e condicionante da transação tributária e de toda e qualquer situação que interfira nos aspectos da regra matriz de incidência tributária. Nos termos da Constituição Federal, a legalidade estrita ${ }^{397}$ é intrínseca a qualquer relação jurídicotributária (art. 150, I da Constituição Federal).

Não podemos, ademais, nos esquecer da necessária tipicidade tributária, pois em se tratando de transação, haverá necessária vinculação da atuação da administração pública à lei, ou seja, suporte para que o contribuinte tenha segurança de que o quanto decidido não está no âmbito de livre decisão por parte da administração pública. ${ }^{398}$

Vale destacar, por oportuno, que a doutrina inglesa salienta que, ainda que se trate de relação entre particulares, questões legais serão sempre centrais e intrínsecas a qualquer processo destinado a solucionar conflitos. A despeito de na transação não haver necessariamente advogados colacionando argumentos e fundamentos legais para sobrepor seus respectivos pontos de vista, nem tampouco não haver uma decisão tomada em caráter independente por um julgador (terceiro estranho ao conflito) neutro com fundamento em

\footnotetext{
${ }^{397}$ Sobre legalidade estrita na esfera tributária, vide acima II.1.5.

${ }^{398}$ Nesse sentido, César García Novoa, Mecanismos alternativos para la resolucion...,p. 97.
} 
disposição legal, a legalidade estará sempre presente em qualquer processo de negociação. ${ }^{399}$

E o próprio CTN, no artigo 171, ao estabelecer que a transação tributária será delineada em lei, ${ }^{400}$ corrobora a necessidade de previsão legal. Ademais, tal previsão não precisa ser complementar na medida em que o próprio $\mathrm{CTN}$, lei recebida com status de complementar pela ordem constitucional vigente, estabelece que poderá haver regulamentação legal sobre a transação.

A esse respeito, vale destacar que a despeito de haver mandamento constitucional no sentido de que a lei complementar é competente para dispor sobre normas gerais em matéria de legislação tributária (artigo 146, III, da Constituição Federal), mediante expressa disposição do CTN no sentido de que a transação poderá ser instituída em lei, entende-se pela desnecessidade de edição de legislação com status complementar para dispor dos detalhes da transação. ${ }^{401}$

Sem prejuízo, o Projeto de Lei 5082/2009 em tramitação no Congresso Nacional que trata da transação tributária pretende alterar a atual redação do artigo 171 do CTN, o

${ }^{399}$ Vale transcrever o entendimento referido:

Legal principles are central to a trial. The issues in the case are defined by law, the lawyers on each side focus their arguments on how the law supports their case, and the judge makes a decision based on and often setting out the application of the law to the case. For a negotiation the legal context is different, but potentially equally important (BLAKE, Susan; BROWNE, Julie; SIME, Stuart. A practical approach to Alternative Dispute Resolution. p. 136).

${ }^{400}$ Vale destacar o entendimento do Tribunal Regional Federal da $4^{\text {a }}$ Região no sentido de que a transação firmada pelo poder público prescinde de autorização expressa por lei, sob pena de nulidade:

ADMINISTRATIVO. CONTRATO ADMINISTRATIVO. CONCESSÃO DE SERVIÇO PÚBLICO. TRANSAÇÃO. IMPOSSIBILIDADE, POR SE TRATAR DE RELAÇÃO DE DIREITO PÚBLICO. AUSENCIA DE PRÉVIA E EXPRESSA AUTORIZAÇÃO LEGISLATIVA. NULIDADE. INTERVENÇÃO DO MINISTÉRIO PÚBLICO. ART.82, III, DO CPC.

1. A transação celebrada entre representante do Poder Público e as concessionárias do serviço público, versando cláusulas do contrato administrativo, sua validade, extensão e eficácia, somente poderão ser apreciadas à luz de regras fixadas pelo direito público.

2. É regra pacífica que as autoridades administrativas não podem transigir, na execução dos contratos administrativos, nem rescindi-los mediante indenização sem lei autorizativa.

3. Precedente do STF (RE no79.102-BA, rel. Min. Bilac Pinto, in RTJ 78/194).

4. In casu, restou configurado o interesse público a exigir a intervenção do Ministério Público no processo, consoante dispõe o art.82, III, do CPC.

5. Interpretação dos arts.1.035 do Código Civil e 82, III, do CPC.

6. Apelação conhecida e provida. (APELAÇÃO CÍVEL No 2000.04.01.097971-2/PR. Rel. DES. FEDERAL CARLOS EDUARDO THOMPSON FLORES LENZ.)

${ }^{401}$ Vale destacar que a lei complementar será fundamental para conferir à transação os efeitos do artigo 151 do CTN, como também para fins de viabilizar que, durante processo de transação e antes de se operar a extinção do crédito tributário, o contribuinte possa emitir certidão positiva de débitos com efeitos de negativa. Tais aspectos encontram-se inseridos no Projeto de Lei que tramita no Congresso Nacional. 
qual passaria a dispor que $(i)$ haveria lei geral ou específica tratando da transação, (ii) não se exigiria o implemento de concessões mútuas e (iii) o objetivo principal seria a composição do conflito ou litígio, em substituição à atual previsão pela determinação do litígio. $^{402}$

Eurico $\operatorname{Santi}^{403}$ critica vorazmente o mencionado projeto de lei de transação por entender impossível a existência de uma norma geral de transação, advogando no sentido de ter havido desrespeito a conceitos essenciais do direito tributário, tais como litígio, motivação, tributo, lançamento tributário, suspensão da exigibilidade, decadência, prescrição, extinção do crédito tributário, todos estes fixados no CTN. O autor entende que a transação com status de coisa julgada (artigo 23 do Projeto de Lei) não seria cabível no nosso ordenamento.

Nos termos acima avaliados, entende-se, no entanto, pela inexistência de óbice constitucional ou mesmo normativo para fins de regulamentação e adoção da transação tributária, na medida em que o crédito tributário é disponível (nos termos da lei, conforme já analisado $)^{404}$ e poderá ser objeto de negociação entre fisco e contribuinte. Assim, a legalidade figura não só como elemento essencial da transação, mas também como seu pressuposto de validade. Caso a transação não tenha fundamento e amparo legal, teremos ofensa não só ao CTN, mas também ao texto constitucional. Em havendo autorização e regulamentação legal, no entanto, não haverá qualquer incompatibilidade com o sistema constitucional tributário vigente.

\subsection{Transação e tributação participativa}

A transação é modalidade de solução de controvérsias inequivocamente autocompositiva, na medida em que, quando adotada, as partes produzem, em comum acordo, mandamento que solucionará a controvérsia, comprometendo-se, livre e voluntariamente, a cumprir com o quanto acordado (termo de transação). Na medida em que as partes alcançam autocompositivamente o termo de acordo, há intensa abertura para

\footnotetext{
402 Para uma análise comparativa da atual redação do art. 171 do CTN e da redação do Projeto de Lei Complementar No. 469/2009, vide GODOY, Arnaldo Sampaio de Moraes, Transação Tributária, p. 138140.

${ }^{403}$ Processo judicial. p. 93-131.

${ }^{404}$ Vide item II.1.1 acima.
} 
diálogo entre as mesmas e, como já tratado acima, ${ }^{405}$ haverá concessões mútuas para que se alcance a solução do litígio.

Arnaldo Sampaio de Moraes Godoy, citando Túlio Rosembuj, afirma que a transação é a "figura jurídica que melhor fomenta o direito de participação do contribuinte junto à Administração". ${ }^{406}$ Tal assertiva vai ao encontro da onda por uma tributação mais participativa e efetiva, sempre atendendo da melhor forma aos interesses da coletividade em detrimento de interesses unilaterais do fisco e/ou do contribuinte envolvido na controvérsia. ${ }^{407}$

Como destaca Heleno Taveira Torres "o princípio jurídico e técnico da praticabildade da tributação impõe um verdadeiro dever ao Legislador de busca dos caminhos de maior economia, eficiência e celeridade para viabilizar a imposição tributária, o que poderá ser alcançado com intensificação da participação dos administrados na gestão tributária e possibilidade de solução extrajudicial de conflitos entre a Administração e os contribuintes".

Ademais, a transação colabora para a consecução de um processo fiscal equitativo, ${ }^{408}$ o qual, no entender de Ricardo Lobo Torres, 409 "mediante o diálogo entre fisco e contribuinte, busca a solução justa do caso concreto", ${ }^{410}$ além de ser determinante para a prevenção de litígios. ${ }^{411}$

\footnotetext{
${ }^{405}$ Vide item III.1.1.

${ }^{406}$ In Transação tributária..., p. 139.

${ }^{407}$ Princípios da segurança jurídica e transação em matéria tributária. Os limites da revisão administrativa dos acordos tributários, p. 299-330.

${ }^{408}$ Acerca do processo fiscal equitativo, vale transcrever o artigo $6^{\circ}$, parágrafo $1^{\circ}$ da Convenção Européia dos Direitos do Homem: "qualquer pessoa tem direito a que a sua causa seja examinada, equitativa e publicamente, num prazo razoável por um tribunal independente e imparcial, estabelecido por lei".

${ }^{409} \mathrm{O}$ autor salienta que o processo fiscal equitativo decorre das necessidades econômicas e sociais inerentes ao processo de globalização e da sociedade do diálogo. Não há dúvidas, enfim, que a transação aprimora o diálogo e contribuirá para a consecução dos valores intrínsecos à tributação equitativa tal como delineada pela doutrina.

${ }^{410}$ Transação, conciliação e processo tributário administrativo equitativo, p.93.

${ }^{411}$ Nesse mesmo sentido, veja o entendimento de Hugo de Brito Machado, Transação e arbitragem no âmbito tributário, p. 127.
} 
A abertura de diálogo entre fisco e contribuinte, ademais, tende a priorizar a consecução do interesse público ${ }^{412}$ na medida em que permite ao administrador que busque a forma de solução que melhor atenderá o interesse envolvido. Por exemplo, por certo não vale a pena manter interminável questionamento judicial de crédito tributário sabidamente não devido pelo contribuinte, quer em razão de evidências que tenham sido apuradas em análise técnica, ${ }^{413}$ quer por força da incidência de determinação legal ou entendimento jurisprudencial consolidado ${ }^{414}$ que afasta o lançamento tal como realizado pela autoridade fiscal.

Heleno Taveira Torres destaca, ademais, que "o princípio jurídico e técnico da praticabilidade ou praticidade da tributação, que se deve estender aos meios de resolução de controvérsias, deve ser repensado e posto como condição de eficiência administrativa”, destacando "a importância da garantia de certeza e praticabilidade dos tributos, como meio de igualdade e segurança jurídica para os contribuintes". 415

A doutrina italiana salienta que a transação envolvendo a administração pública é tradicional no sistema e, especificamente na seara tributária, traz benefícios que resultam na consecução do interesse público, sobretudo em se considerando o tempo que seria

412 Acercada homenagem ao interesse público, vale transcrever a posição de GODOY, Arnaldo Sampaio de Moraes (Transação tributária: paradoxos e possibilidades, p. 27.):

Remete-se à observância do interesse público e da conveniência administrativa. Distancia-se de tipologia fechada, que plasma o interesse público na intransigência. Tem-se nova dimensão de discricionariedade, oxigenada pela participação do interessado, do cidadão que recolhe tributos, a quem compete também fiscalizar como é cobrado.

Mitigam-se alguns focos de tensão. Minimiza-se a demanda dos serviços do Judiciário. Reduzem-se os custos de aquiescência. Persegue-se a eficiência, que deixa de ser paradigma imaginário da administração pública, inserido em cláusula constitucional, plasmando-se em medida concreta, realista, de resolução de problemas.

${ }^{413}$ Perícia judicial ou mesmo diligência durante o julgamento na esfera administrativa.

${ }^{414}$ Interessante destacar que a Procuradoria da Fazenda Nacional editou Ato Declaratório que a dispensa de contestar e/ou apresentar recurso em se tratando de matérias cujo entendimento jurisprudencial já tenha sido consolidado em favor do contribuinte.

No entanto, a prática jurídica demonstra que nem sempre a direção de atuação dos defensores da Fazenda Nacional é adotada, na medida em que ainda há recursos sendo interpostos e Contestações apresentadas em lides que tratam das matérias elencadas no mencionado ato normativo.

Ademais, questiona-se a efetividade da medida pois, a despeito de os procuradores serem dispensados de questionar judicialmente as controvérsias cujos méritos tratem de questões pacificadas, o contribuinte permanece sendo coagido a buscar o judiciário para defesa de seus interesses ainda que o assunto tenha sido decidido jurisprudencialmente em seu favor pois não há mecanismo perante as autoridades fiscais que o libere do questionamento judicial para fins de ver prevalecer seu direito. Ou seja, há fértil campo para que autoridade fiscal e contribuinte acertem postura para fins de evitar que questionamentos desnecessários e cuja solução pode ser antecipada antes mesmo de proposta medida judicial competente.

415 Arbitragem e transação em matéria tributária, p. 196. 
necessário para término dos litígios não fosse a possibilidade de acordo entre fisco e contribuinte. $^{416}$

Há, no entanto, aspectos que podem advogar contra a transação tributária. Tratemos, nesse tocante, da questão da corrupção, ${ }^{417}$ comumente apontada pela doutrina contrária á transação tributária ${ }^{418}$ como óbice intransponível para qualquer abertura de diálogo entre fisco e contribuinte.

É notório que a corrupção se encontra enraizada nos mais diversos setores da sociedade brasileira. De outro lado, afastar instituto deveras benéfico sob a justificativa de que sua inviabilidade residiria na ampla possibilidade de indevido conluio entre sujeitos da relação jurídico-tributária não parece razoável, afora contribuir para um afastamento cada vez mais acentuado da consecução do melhor interesse público. Evitar o diálogo apenas e tão somente em razão de haver margem para percebimentos de vantagens indevidas é postura que não coaduna com o dinamismo e com a complexidade das atuais relações que envolvem poder público e administrado, mormente na seara tributária. ${ }^{419}$

${ }^{416}$ Confira-se o original:

"L'applicabilità della transazione anche alle pubbliche amministrazioni è da tempo del secondo ottocento; anche se, ovviamente, per la parte dell'attività amministrativa che è assoggettata al diritto comune e sempre nel rispetto del c.c. ordine pubblico.

La transazione ha trovato finora espressioni rilevanti in matéria fiscale, di esportazione e regime dognale. Se ne auspica l'applicazione generalizzara anche in altri settori, come gli appalti publici, specie AL fine di definire preventivamente gli oneri finali complessivi delle opere, delle forniture o dei servizi oggetto degli appalti, e di prevenire Il contenzioso. In effetti, i tempi di definizione di queste controversie sono particolarmente negativi per Il pubblico interesse, specie quando sono stati assunti provvedimenti cautelari Che ritardano la realizzazione dell'appalto" (CHITI, Mario, in La forme di resoluzione delle controversie con la pubblica amministrazione alternative alla giurisdizione, p. 9).

${ }^{417}$ Importante destacar que o jurista Miguel Reale alerta que nem mesmo o Judiciário é livre da corrupção (Crise da Justiça e Arbitragem, p. 319,).

${ }^{418}$ Nesse sentido, vale transcrever a opinião de SARAIVA FILHO, Oswaldo Othon Pontes, que, analisando o projeto de lei de transação pendente no Congresso Nacional, traz não só o receio à corrupção mas também comenta a postura retroativa das autoridades fiscais quanto à aprovação do projeto, na medida em que "atualmente, com a prevalência do princípio da legalidade estrita no campo tributário, com quase nenhum espaço para discricionariedade, as injunções políticas em matérias técnicas e os favorecimentos pessoais são, praticamente, nulos, tudo depende, exclusivamente, de expressa disposição constitucional e de específica previsão legal. Prevalece a vontade da lei, e não do administrador. Com o aumento da discricionariedade administrativa no campo tributário, representantes desse grupo receiam que essa injunção seja fortalecida - a utilização do tributo para fins políticos ou de favorecimentos pessoais ou para o atendimento dos detentores do poder econômico. E a sociedade sabe - próprio art. 14 da Lei Complementar $n^{\circ}$ 101, (LRF) tem essa previsão -, que não há milagres nessa área: se há, de fato, uma renúncia, mesmo com a capa da transação, redução relevante de tributo e seus acessórios, outros grupos de contribuintes serão chamados a se sacrificar, ainda mais, para arcar com o prejuízo, para que o Estado tenha recursos de que necessita, para cumprir os seus encargos, para que preste, adequadamente, os inerentes serviços públicos" (Visão da sociedade sobre transações tributárias).

${ }^{419}$ Cf. item II.2.1 supra. 
Sob esse aspecto, Hugo de Brito Machado ${ }^{420}$ salienta que a regulamentação da transação contribuirá para o combate à corrupção justamente por haver exigência de que a fiscalização tributária justifique a conveniência e pertinência do termo a ser firmado, proporcionando sempre uma atuação transparente e oficializando as transações que surgirão.

Outro aspecto apontado pela doutrina contrária à adoção da transação tributária reside no fato de que ao ser viável a transação, haveria possibilidade de incentivo aos contribuintes que deixam de adimplir tempestivamente com suas obrigações tributárias justamente por saberem que haverá margem para ulterior adimplemento sem severos ônus decorrentes da mora. Nesse tocante, vale tratar dos programas de pagamento incentivados de tributo comumente concedidos pelos fiscos brasileiros.

\subsection{Os programas para pagamento incentivado de tributos}

Nas diversas esferas do poder público brasileiro vem sendo cada vez mais comum a criação de programas de pagamento incentivado de tributos, comumente denominados anistias, por meio dos quais o poder público concede reduções (significativas) dos encargos moratórios ${ }^{421}$ para fins de incentivar contribuintes que tenham débitos em aberto a quitar suas obrigações físcais. ${ }^{422}$

Ou seja, o poder público apresenta condições e critérios para que o contribuinte que assim deseje, caso preenchidos os pressupostos necessários, opte por quitar suas obrigações fiscais. Não se trata, assim, de solução pactuada entre as partes nem tampouco de solução autocompositiva do litígio. Vale, assim, avaliar se tais programas podem ser considerados como transação.

O Superior Tribunal de Justiça, por diferentes razões de decidir, desvinculou a extinção da obrigação tributária nos termos de tais parcelamentos da solução da

\footnotetext{
${ }^{420}$ In Transação e arbitragem no âmbito tributário, p. 127.

${ }^{421}$ Vale destacar que Projeto de Lei 5082/2009, que trata da transação tributária somente permite que o poder público abra mão de encargos moratórios ao firmar transação tributária (artigos $6^{\circ}$ e $7^{\circ}$ ).

${ }^{422}$ Por exemplo, Lei 11.941/2009.
} 
controvérsia da transação. Quer em razão de o Código Civil determinar que a transação somente se operaria quanto a direito disponível, ${ }^{423}$ quer por não se tratar de extinção da lide em razão de acordo, ${ }^{424}$ mas sim de adimplemento da obrigação, a corte superior manifesta entendimento no sentido de desvincular tais programas de pagamento incentivados de tributo à transação.

Em oportunidade diversa, o STJ tratou a adesão a programa de pagamento incentivado de tributos como verdadeira transação ${ }^{425}$ por entender que o contribuinte, ao aderir, teria aberto mão do questionamento judicial e, a seu turno, o fisco teria optado por não receber honorários advocatícios.

${ }^{423}$ Veja trechos de ementa de julgado nesse sentido:

PROCESSUAL CIVIL. EMBARGOS À EXECUÇÃO FISCAL. EXTINÇÃO DO PROCESSO EM VIRTUDE DE ADESÃO DO CONTRIBUINTE A PROGRAMA DE PARCELAMENTO OU PAGAMENTO À VISTA DE CRÉDITOS TRIBUTÁRIOS. TRANSAÇÃO NÃO-CONFIGURADA. CONDENAÇÃO EM HONORÁRIOS ADVOCATÍCIOS. CABIMENTO.

1. A adesão do contribuinte a programa instituído por lei para fins de parcelamento ou pagamento à vista de créditos tributários não configura transação, pois o Código Civil só permite a transação quanto a direitos patrimoniais de caráter privado (art. 841). Se recair sobre direitos contestados em juizo, a transação será feita por escritura pública, ou por termo nos autos, assinado pelos transigentes e homologado pelo juiz (art. 842). De acordo com o Código Tributário Nacional, a lei pode facultar, nas condições que estabeleça, aos sujeitos ativo e passivo da obrigação tributária celebrar transação que, mediante concessões mútuas, importe em determinação de litígio e consequente extinção de crédito tributário (art. 156, III, c/c art. 171). A lei indicará, ainda, a autoridade competente para autorizar a transação em cada caso (art. 171, parágrafo único). Por não se tratar de transação, não se aplica ao caso o $\$ 2^{\circ}$ do art. 26 do Código de Processo Civil, segundo o qual, "havendo transação e nada tendo as partes disposto quanto às despesas, estas serão divididas igualmente". (...). (REsp 1244347. $2^{\mathrm{a}}$ T. Ministro MAURO CAMPBELL MARQUES. J. 14/04/2011).

${ }^{424}$ Confira-se trechos de ementa de julgado:

DIREITO PROCESSUAL CIVIL E TRIBUTÁRIO. EXECUÇÃO FISCAL. EXTINÇÃO. ADIMPLEMENTO DA DÍVIDA. PARCELAMENTO. HONORÁRIOS DE SUCUMBÊNCIA.

(...)

7. A extinção da Execução Fiscal pela quitação da dívida objeto de parcelamento tributário não configura hipótese de encerramento do processo por transação entre as partes. Em verdade, a sentença não teve como fundamento o negócio bilateral, mas o completo adimplemento da obrigação. Nesse caso, aplica-se o disposto no art. 26, caput, do CPC, pois a satisfação do débito equivale ao reconhecimento do pedido.

8. Agravo Regimental não provido. (AgRg no REsp 1280482, $2^{\mathrm{a}}$ Turma, Rel. Ministro HERMAN BENJAMIN, j. 07/02/2012).

${ }^{425}$ Vale transcrever a ementa:

AGRAVO REGIMENTAL EM RECURSO ESPECIAL. TRIBUTÁRIO. EXECUÇÃO FISCAL. DESISTÊNCIA DOS EMBARGOS À EXECUÇÃO PELO CONTRIBUINTE PARA SUA INCLUSÃO EM PARCELAMENTO FISCAL. DESCABIMENTO DA CONDENAÇÃO EM HONORÁRIOS ADVOCATÍCIOS. AGRAVO REGIMENTAL DESPROVIDO.

(...)

2. Trata-se, em verdade, de uma verdadeira transação, em que uma parte, o contribuinte, abre mão da ação judicial, e a outra, a FAZENDA, em contrapartida, dos honorários advocatícios, com o objetivo maior de satisfação do próprio crédito da Receita Federal, pois é sabido que as demandas judiciais consomem demasiado tempo.

3. Agravo Regimental desprovido. (AgRg no REsp 1231738. $1^{\text {a }}$ Turma. Rel. Ministro NAPOLEÃO NUNES MAIA FILHO. J. 08/11/2011). 
Arnaldo Sampaio de Moraes Godoy ${ }^{426}$ entende que a transação tributária já é realidade no Brasil na medida em que os programas de parcelamento de tributos configuram verdadeiras hipóteses de transação, na medida em que há concessões mútuas: o fisco renuncia aos valores correspondentes aos descontos concedidos a título de encargos moratórios concedidos pelo programa de parcelamento e, a seu turno, o contribuinte reconhece devido o tributo e aceita efetuar o pagamento dos valores necessários à plena quitação do débito.

Analisando especificamente o Programa de Recuperação Fiscal (Refis) instituído pela Lei 9.964/2000, Hugo de Brito Machado ${ }^{427}$, entendeu pela natureza de transação do programa na medida em que a finalidade essencial do programa é a extinção dos litígios pendentes entre a União Federal e os contribuintes.

Destarte, os programas de incentivo de pagamento de tributos configuram verdadeira modalidade transação, na medida em que há solução de litígio mediante concessões mútuas quando o contribuinte aceita pagar parte do valor atualizado do débito e o fisco concede algum desconto nos encargos incidentes sobre o débito fiscais. Tais concessões conferem necessária margem de discricionariedade ao ato das partes envolvidas no litígio a viabilizar sua qualificação como transação.

\footnotetext{
${ }^{426}$ Vale transcrever a opinião do autor:

"A transação já é fato entre nós. Materializada em parcelamentos de gaveta, em medidas de conciliação, em fórmulas de parcelamento, é elemento comum na prática tributária contemporânea. Refiro-me, por exemplo, ao Programa de Recuperação Fiscal (REFIS), que qualificou regime de parcelamento de débitos fiscais perante a então Secretaria da Receita Federal, à ProcuradoriaGeral da Fazenda Nacional e ao Instituto Nacional de Seguridade Social.

(...)

Mais tarde, com a Lei No. 10.684, de 30 de maio de 2003, implementou-se um novo modelo de parcelamento especial de débitos junto à também então Secretaria da Receita Federal, à Procuradoria-Geral da Fazenda Nacional e ao Instituto Nacional de Seguridade Social.

(...)

Tem-se, de fato, a renúncia de recursos e do processamento das execuções, por parte do devedor e, de outro lado, a renúncia de valores (supostamente irrenunciáveis) por parte da Administração. É essa reciprocidade de concessões, na qual todos ganham, que qualificam a transação, ainda que não se altere o Código Tributário Nacional e que não se tenha uma Lei Geral de Transação” (in Transação tributária: introdução à Justiça Fiscal Consensual”. p. 28-31).

${ }^{427}$ In Transação e arbitragem no âmbito tributário, p. 122.
} 


\subsection{A lei de responsabilidade fiscal}

Importante avaliar, ainda tratando da transigibilidade do crédito tributário, da interface entre a transação tributária e a responsabilidade fiscal, na medida em que a transação, por implicar vez por outras em renúncia fiscal, estará jungida aos mandamentos da Lei de Responsabilidade Fiscal (lei complementar No. 101/2000).

Ao tratar da transação tributária, o legislador deverá observar as premissas e condicionantes nos casos em que a transação importe em renúncia fiscal por parte do ente tributante, diante da disposição legal acerca dos cuidados necessários em decorrência da existência de renúncia por parte do poder público. ${ }^{428}$

Vale refletir, nesse ponto, sobre o que configuraria renúncia fiscal, a ensejar a incidência da Lei de Responsabilidade Fiscal. Pode-se mencionar a remissão, anistia, dispensa de juros, parcelamento, dação em pagamento, p.ex., como modalidades pelas quais o sujeito ativo da relação jurídico tributária poderá instituir programa a ser aderido pelos contribuintes para quitar suas dívidas tributárias. Nesse caso, é certo que haveria, nos termos da lei, dispensa pela arrecadação de parte do crédito tributário. Qualquer uma de tais previsões, nesses termos, demandará uma análise orçamentária a justificar a relevante renúncia de receita.

${ }^{428}$ Confira-se o disposto na norma sobre a renúncia fiscal:

Art. 14. A concessão ou ampliação de incentivo ou benefício de natureza tributária da qual decorra renúncia de receita deverá estar acompanhada de estimativa do impacto orçamentário-financeiro no exercício em que deva iniciar sua vigência e nos dois seguintes, atender ao disposto na lei de diretrizes orçamentárias e a pelo menos uma das seguintes condições:

I - demonstração pelo proponente de que a renúncia foi considerada na estimativa de receita da lei orçamentária, na forma do art. 12, e de que não afetará as metas de resultados fiscais previstas no anexo próprio da lei de diretrizes orçamentárias;

II - estar acompanhada de medidas de compensação, no período mencionado no caput, por meio do aumento de receita, proveniente da elevação de alíquotas, ampliação da base de cálculo, majoração ou criação de tributo ou contribuição.

$\S I^{o}$ A renúncia compreende anistia, remissão, subsídio, crédito presumido, concessão de isenção em caráter não geral, alteração de alíquota ou modificação de base de cálculo que implique redução discriminada de tributos ou contribuições, e outros benefícios que correspondam a tratamento diferenciado.

$\S 2^{\underline{o}}$ Se o ato de concessão ou ampliação do incentivo ou benefício de que trata o caput deste artigo decorrer da condição contida no inciso II, o benefício só entrará em vigor quando implementadas as medidas referidas no mencionado inciso.

$\S 3^{\circ} \mathrm{O}$ disposto neste artigo não se aplica:

I - às alterações das alíquotas dos impostos previstos nos incisos I, II, IV e V do art. 153 da Constituição, na forma do seu § 10 ;

II - ao cancelamento de débito cujo montante seja inferior ao dos respectivos custos de cobrança. 
Vale destacar, no entanto, que o histórico dos programas de pagamento incentivado de tributos que concedem redução de penalidades representa relevante arrecadação, servindo como incentivador ${ }^{429}$ ao pagamento de valores devidos pelos contribuintes e consequente mecanismo para viabilizar incremento na arrecadação tributária.

Diferentemente ocorrerá com o término de determinado litígio já travado entre fisco e contribuinte, pois não necessariamente restará configurada renúncia fiscal. Isso porque por vezes o contribuinte tem fundamentos para desconstituir total ou parcialmente o lançamento tributário em discussão e o término do litígio mediante transação, afora viabilizar imediata arrecadação nos termos a serem acordados, representará economia de recursos com a defesa do Estado na controvérsia, que sabidamente onera todas as esferas do nosso poder público.

Importante, no entanto, assegurar que não haja em transações tributárias tratamento diferenciado ao contribuinte envolvido, sob pena de invalidação do negócio jurídico. Nesse caso, por certo a transação estaria sujeita à Lei Complementar No. 101/2000 e deverá justificar numericamente a viabilidade e adequação da medida, nos termos descritos na norma. $^{430}$

Importante, nesse contexto, ressaltar que as renúncias fiscais somente poderão ocorrer nos exatos termos da lei, o que mitiga a parcela de discricionariedade do agente administrativo. ${ }^{431}$ Tal aspecto decorre não só do artigo 171 do CTN, mas também da

${ }^{429}$ É bem certo que tais programas acabam por homenagear maus pagadores que, não honrando com suas obrigações tributárias tempestivamente e muitas vezes sequer adotando as medidas necessárias para regular questionamento do crédito tributário, aproveitam tais oportunidade para regularizar sua situação fiscal, beneficiando-se de relevantes e expressivos descontos periodicamente concedidos pelos entes tributantes.

A título ilustrativo, veja o Estado de São Paulo que em 2008 criou o PPI do ICMS (Decreto 56.102/2012) e, já em 2013, instaurou o PEP do ICMS, outro programa incentivado para pagamento de tributos em atraso (Decreto No. 58.811/2012).

$\mathrm{Na}$ esfera federal não é diferente: há uma série de programas de incentivo de pagamento de tributos fiscais em atraso. Dentre os mais recentes podemos citar a Lei 10.833/2003 e a Lei 11.941/2009.

${ }^{430}$ Nesse sentido, vide Hugo de Brito Machado, in Transação e arbitragem no âmbito tributário, p. 119-120.

${ }^{431}$ Nesse sentido, ver Oswaldo Othon de Saraiva Filho, a transação e a arbitragem no direito constitucionaltributário brasileiro, p. 62-63. Vale transcrever trecho do entendimento em questão:

Portanto, margem não poderá haver para excesso de discricionarismo por parte da administração tributária, não sendo admissível uma espécie de delegação legislativa nessas matérias, todas elas submetidas ao âmbito da reserva legal.

Diante da inocorrência, ainda, de uma pretensão resistida, ou de inexistência de uma relação jurídica duvidosa, posta em processo administrativo ou judicial, a transação não tem objeto ou 
legalidade estrita tributária (conforme artigo 150 da Constituição Federal) e princípios que norteiam a atuação dos administradores públicos.

Ademais, qualquer transação que comprovadamente traga indevida vantagem ao particular, poderá ser invalidada com fundamento no art. 14 da LRF, como afirma Hugo de Brito Machado. $^{432}$

Assim, conclui-se que a Lei de Responsabilidade Fiscal deve ser observada e cumprida para fins de conferir fundamento de validade à transação tributária, mas não afasta sua viabilidade, sobretudo diante da preponderância de atendimento ao interesse público.

\subsection{Os porquês da transação}

Diante das constatações acima, as quais consideram o crédito tributário objeto transacionável, sempre em atendimento ao estrito mandamento legal e, ademais, observadas as nuances da Lei de Responsabilidade Fiscal, tudo em linha com a cada vez mais crescente noção de tributação participativa e equitativa, e também em respeito à novel concepção de interesse público, vale analisar quais seriam as vantagens a incentivar sejam firmados acordos entre fisco e contribuinte para solução de controvérsias tributárias.

Ao analisar a transação tributária, Ricardo Lobo Torres ${ }^{433}$ salienta que o instituto aprimoraria a igualdade entre fisco e contribuinte, a ponderação e proporcionalidade da tributação e da atuação dos agentes públicos, a transparência, economicidade, além dos princípios constitucionais ligados à liberdade, justiça, capacidade contributiva, segurança jurídica, legalidade, tipicidade, confiança, supremacia do interesse público e até mesmo a indisponibilidade do crédito fiscal.

finalidade, parecendo um absurdo se cogitar de uma transação preventiva, para prevenir litígio, quando, por exemplo, sequer ocorreu o fato gerador, ou exista uma relação jurídico-tributária em conflito, ou impugnação administrativa ou judicial (p. 63).

${ }^{432}$ A transação no direito tributário, p. 67.

${ }^{433}$ In Transação, conciliação e processo tributário administrativo equitativo, p. 96-109. 
Susan Blake, Julie Browne e Stuart Sime ${ }^{434}$ trazem como vantagens da transação seu caráter flexível, os baixos custos envolvidos, a possibilidade de as partes envolvidas manterem-se no controle da solução a ser pactuada, bem como a aprovarem, bem como o caráter privado da negociação.

De outro lado, dentre as possíveis desvantagens da transação os mesmos autores apontam as dificuldades a serem enfrentadas durante um processo de transação: ${ }^{435}$ o sucesso da transação dependerá da extensão e profundidade da análise das questões controversas para que as soluções possam ser adequadamente pactuadas; a satisfatoriedade da decisão dependerá muito das habilidades dos negociadores, da estratégia e das táticas adotadas; os resultados podem não ser satisfatórios para uma das partes; e a informalidade pode levar à baixa efetividade da transação.

A lei tributária terá que trazer os limites e situações nas quais a transação poderá se operar, mas a própria natureza do instituto exige que haja certa margem de discricionariedade por parte dos sujeitos envolvidos para pactuarem a solução que as vinculará e extinguirá o litígio.

As soluções de controvérsias autocompositivas contribuem não só para a pacificação social, mas também para a construção de uma relação frutífera entre as partes envolvidas. Na seara tributária, tal aspecto é por demais vantajoso sobretudo na medida em que a natureza continuativa da relação é deveras beneficiada pela construção de um bom relacionamento entre as partes.

Ademais, a celeridade da solução transacional do conflito é benéfica a ambas as partes e ao próprio sistema, pois permitirá que uma solução pactuada entre as partes solucione com brevidade e definitividade a controvérsia.

Desse modo, a transação contribui para que a relação entre fisco e contribuinte se aprimore e evolua, na medida em que incentiva não só o diálogo, mas também um processo de tomada de decisão que incrementa a pacificação social e o relacionamento

${ }^{434}$ A practical approach to Alternative dispute resolution, p. 27-28.

${ }^{435}$ A practical approach to Alternative dispute resolution, p. 28. 
entre sujeitos tradicionalmente colocados em posições diametralmente opostas e contrapostas em qualquer relação que se instaure. 


\section{CAPÍTULO 2 - A REGULAMENTAÇÃO DA TRANSAÇÃO}

Como acima exposto, a transação tributária, para ter validade, prescinde de disposição legal e terá seu fundamento de validade na lei, a qual deverá tratar dos pressupostos e aspectos procedimentais essenciais a serem observados como forma de conferir validade ao ato decisório que advier. ${ }^{436}$ Tal como na regulamentação da arbitragem, ${ }^{437}$ trataremos de alguns aspectos para verificar se, procedimentalmente, a transação tributária seria viável.

\subsection{Competência para transacionar}

Iniciemos o assunto a partir da análise da competência do agente representante do sujeito ativo da relação jurídico tributária. O crédito tributário poderá ser objeto de transação na medida em que o agente responsável por firmar o termo respectivo detenha autorização legal ${ }^{438}$ para tanto. Tal necessidade é decorrência direta da tipicidade fechada em matéria tributária ${ }^{439}$ e proporcionará à transação fundamento de validade.

${ }^{436}$ Vale, quanto à natureza e alcance da transação tributária, destacar o entendimento de RIBAS e RIBAS: Como meio alternativo para solução de controvérsias entre o fisco e os contribuintes a transação é uma forma de compor o litígio. Em vez de se encomendar a solução a um árbitro ou a um juiz são as partes interessadas que a estabelecem. Sendo um negócio jurídico a compor, um litígio entre as partes, o contrato de transação tem o mesmo valor de uma sentença (que as partes dão a si mesmas). Ao dirimir o conflito a transação declara, fixa e dá certeza às relações jurídicas entre as partes. A transação pode ser vista também a partir de procedimentos como a mediação e a conciliação ou a utilização da própria arbitragem. (Arbitragem como meio alternativo na solução de controvérsias tributárias, Revista Tributária e de Finanças Públicas, vol. 60, p. 223, jan. 2005).

${ }^{437}$ Sobre semelhanças e diferenças entre a arbitragem e a transação, ver ESQUIVEL, p. 90-91.

${ }^{438}$ A jurisprudência menciona não só autorização legal, mas defende que a autorização seja específica para a prática do ato. Confira-se:

PREVIDENCIÁRIO - ACORDO - PROCURADOR AUTÁRQUICO - PORTARIA N ${ }^{\circ}$ 4.450/89, DO MPAS - PODERES ESPECIAIS PARA TRANSIGIR - INTERVENÇÃO DO MP NAS TRANSAÇÕES DO INSS E DO SEGURADO -O Procurador Autárquico necessita, também, de autorização expressa para transigir nos termos da Portaria $n^{\circ} 4.450$, de 16/05/89, do MPAS, que normatizou a realização de transações e conciliações judiciais. -A não observância da Portaria $n^{\circ}$ 4.450/89 e, também, a ausência da intervenção do Ministério Público, consoante os termos insertos no inciso III do artigo 82 do CPC, nas causas nas quais o INSS é parte litigante, geram nulidade. -Apelação provida. Sentença anulada. (TRF 2a Região. AC 200202010379919. Rel. Desembargador Federal FRANCISCO PIZZOLANTE. $3^{\mathrm{a}}$ Turma. DJU - Data::10/12/2003). No mesmo sentido, AC 200102010155790 e AC 200302010084080 do mesmo tribunal.

${ }^{439}$ Constituição Federal, art. 150, I. 
Heleno Taveira Torres ${ }^{440}$ destaca que, ainda que a transação não seja o método preferencial do agente para dirimir o conflito, caso haja determinação legal pela prática do ato será mandatória a solução da controvérsia por transação sob pena de perpetrar-se ilegalidade do ato tendente a buscar forma diversa para solução da controvérsia e, consequentemente, afronta à Constituição Federal.

O agente capaz de transacionar ${ }^{441}$ quanto a obrigações tributárias precisará ter, além de autorização legal para tanto, legitimidade para dispor ou mesmo alienar, ${ }^{442}$ na medida em que as ações são intrínsecas ao ato de realizar concessão mútua na seara tributária. Em se tratando do poder público, qualquer manifestação que implique em disposição do bem público precisará de autorização legal específica, na medida em que tal ato deverá atender ao interesse público e não poderá implicar em prejuízo do interesse da coletividade em detrimento do interesse do particular envolvido. É essencial, portanto, que o agente competente esteja dotado de boa-fé f43 $^{4}$ e assegure o cumprimento, por parte do poder público, do acordo a ser firmado.

Hugo de Brito Machado manifesta opinião no sentido de que somente "autoridades de escalões superiores" poderão firmar a transação tributária para que "se alguma discricionariedade ainda restar, seja mais fácil o controle do ato que há de ser praticado sempre no interesse da Fazenda Pública", 444

${ }^{440}$ In Princípios da segurança jurídica e transação em matéria tributária..., p. 309.

${ }^{441}$ Vale destacar que o Projeto de Lei 5082/2009, que trata da transação tributária, confere ao Procurador Geral da Fazenda Nacional o poder de designar Procuradores capazes de transacionar em nome da Fazenda Nacional, bem como critérios materiais para anuência do próprio Procurador Geral ou do Ministro da Fazenda.

${ }^{442}$ Nesse sentido, Onofre Alves Batista Junior trata de tais prerrogativas a todo e qualquer agente autorizado a firmar transação administrativa:

"A cláusula setorial autorizativa de transação administrativa não é uma norma de atribuição genérica de competência para celebrar contratos administrativos alternativos, mas norma que permite o afastamento da solução genérica, em determinados casos, quando se verificar que essa solução não é capaz de proporcionar o melhor interesse público possível, quando comparada com as possibilidades de solução concertada” (Transações administrativas, p. 481).

443 Nesse sentido, vale destacar que Heleno Taveira Torres salienta que "O fundamento das transações tributárias é a confiança recíproca, amparada na boa-fé objetiva, no respeito ao pacta sunt servanda e no fundamento constitucional do ato jurídico perfeito" (in Princípios de segurança jurídica e transação em matéria tributária. Os limites da revisão administrativa dos acordos tributários, p. 310).

${ }^{444}$ A transação no direito tributário, p. 65. 
Quanto à margem de discricionariedade intrínseca à transação, Fabio Artigas Grillo $^{445}$ afirma que "a legislação instituidora da transação em matéria tributária deve, nesse aspecto, necessariamente propiciar um maior grau de flexibilização, conferindo certa margem de discricionariedade à Administração Tributária, com o intuito de compor ou solucionar, a depender da situação, conflitos envolvendo obrigações de cunho tributário"

A título exemplificativo, mencione-se que a Lei Orgânica do Ministério Público da União prevê as condições especiais em que os órgãos do Ministério Público da União poderão transigir ou fazer composições, sempre dependendo de autorização expressa e específica do Procurador-Geral. ${ }^{446}$

Feitas as observações quanto aos aspectos de competência por parte do agente representante do sujeito ativo da relação jurídico-tributária, vale tecer comentários acerca de eventuais critérios que capacitarão o contribuinte a firmar a transação tributária, na qualidade de sujeito passivo da relação.

Nos Estados Unidos da América há o instituto do Offer in Compromising, ${ }^{447}$ pelo qual o fisco federal (IRS - Internal Revenue Service) avalia a capacidade do contribuinte de quitar o débito. Leva em consideração, para tanto, sua renda, seus gastos e suas posses, permitindo, quando entender prudente, que o débito seja quitado mediante pagamento parcial do total devido. Aceita a proposta pelo fisco, o contribuinte realisará o pagamento em dinheiro (à vista ${ }^{448}$ ou em parcelas). ${ }^{449}$ Verifica-se que, com o pagamento das condições acordadas entre as partes, se dará a extinção do crédito tributário.

\footnotetext{
445 Transação e justiça tributária, p. 174-175.

${ }^{446}$ Confira-se o teor do artigo 23 da Lei n. 1341/1951:

Salvo quando autorizados pelo Procurador Geral, os órgãos do Ministério Público da União não podem transigir, comprometer-se, confessar, desistir ou fazer composições.

Parágrafo único. Sempre que julgarem conveniente, deverão representar confidencialmente ao Procurador Geral para que êste, opinando a respeito, obtenha do poder competente a necessária autorização para transigir, confessar, desistir ou fazer composições.

447 As regras aplicáveis a pessoa física estão disponíveis em http://www.irs.gov/Individuals/Offer-inCompromise-1. Note que há expressa previsão de recurso administrativo em face da decisão denegatória da proposta de acordo.

${ }^{448}$ Lump sum cash payment.

${ }^{449}$ Periodic payment.
} 
Sugere-se, seguindo o modelo citado, que um exame da saúde financeira do contribuinte seja relevante para fins de capacitá-lo a transacionar quanto a créditos tributários. Certo contribuinte insolvente (ou em processo de decretação de insolvência) não deveria ter a opção pela transação quanto a créditos tributários em aberto na medida em que a medida seria meramente protelatória, pois há relevantes indícios de que as obrigações pecuniárias decorrentes do acordo não serão adimplidas e somar-se-ão ao universo de prestações pendentes.

O objetivo da transação é a composição do litígio e para tanto o Poder Público poderá dispor de valores que em condições normais receberia. Não faz sentido, desse modo, que tal disposição sirva para extinguir uma obrigação inadimplida para surgimento de nova obrigação a ser igualmente descumprida pelo sujeito passivo da relação jurídicotributária.

Contrariamente ao raciocínio acima, o Projeto de Lei 5.082/2009 traz a possibilidade de o contribuinte em processo de insolvência civil, falência ou recuperação judicial transigir com o físco para fins de composição do litígio tributário, estabelecendo, no entanto, que "quando se apurar que o sujeito passivo concorreu com dolo, fraude ou simulação para sua insolvência ou falência (...) o respectivo termo não poderá ser concluído ou será nulo”. No entanto, a averiguação dos elementos que nos termos do projeto de lei afastariam a viabilidade da transação é por demais complexa e dependerá de verificações que, no nosso entender, poderão tornar inviável a dinamização das tratativas tendentes a alcançar a transação.

Contrariamente se verifica com a previsão pela recuperação tributária, que é tendente a auxiliar o contribuinte em momentânea situação de crise econômico-financeira, com vistas a manter as atividades e deixar de prejudicar os empregados e clientes da pessoa jurídica (artigos 35 e seguintes do projeto retrocitado). Previsão que se entende não só louvável socialmente, mas com ampla aplicabilidade na rotina de país que tem notória elevada carga tributária.

Por fim, parece razoável que responsáveis tributários possam transigir com o poder público na medida e extensão de sua responsabilidade pelo crédito tributário, sobretudo em razão de poderem ter por interesse solucionar a controvérsia quanto ao crédito tributário 
pendente como forma de cessar não só o objeto (crédito tributário), mas também sua responsabilização.

\subsection{Momento para se instaurar a transação}

Tal como avaliado com relação à arbitragem, ${ }^{450}$ cumpre verificar se a transação poderá ocorrer preventivamente à constituição do crédito tributário ou se somente poderá servir para solucionar a controvérsia havida após já constituído o crédito tributário, ou mesmo no curso do processo administrativo, judicial ou arbitral.

A discussão aprofunda-se em se tratando de matéria tributária sobretudo em razão de haver previsão na própria definição de transação do CTN (artigo 171) acerca de sua ocorrência estar necessariamente vinculada à prevenção ou ao término de litígio entre as partes (em linha, saliente-se, com a definição prescrita no artigo 840 do Código Civil).

A experiência alienígena sugere que poderia haver requisitos prévios condicionantes à viabilidade do acordo. Como exemplo, a lei tributária italiana estabelece que, em se tratando de controvérsia tributária não superior a 20.000 Euros, o contribuinte, antes de adentrar na discussão judicial, deve questionar administrativamente a cobrança tributária, momento no qual poderá propor solução da controvérsia por mediação (“motivata proposta di mediazione"). ${ }^{451}$ Caso o contribuinte não o faça, a própria administração poderá propor a mediação ao contribuinte. Ressalte-se, no entanto, que a já estipulada necessidade de apresentação de recurso administrativo como pressuposto da ação judicial foi considerada inconstitucional, conforme relata Falsitta. ${ }^{452}$

Não parece que similar condição prosperaria no direito brasileiro na medida em que se exigir seja percorrida determinada esfera contenciosa como pressuposto para que se opere qualquer espécie de entendimento entre fisco e contribuinte ofenderá a inafastabilidade da jurisdição e a livre iniciativa, asseguradas constitucionalmente.

\footnotetext{
${ }^{450}$ Cf. item II.2.2 supra.

${ }^{451}$ Nesse sentido, FERRARA e BELLÈ, op cit., p. 161.

${ }^{452}$ Gaspare FALSITTA, Manuale di Diritto Tributario, p. 558.
} 
Nesse tocante, Hugo de Brito Machado ${ }^{453}$ entende que a transação somente poderá ser instaurada quando já existente o litígio, ou seja, não poderia ser preventiva à existência deste. Para tanto, o autor qualifica como litígio a discussão judicial ou administrativa do crédito tributário, sempre configuradas com a propositura de ação judicial ou após instauração de contencioso administrativo para questionamento do crédito tributário constituído pela autoridade administrativa. ${ }^{454}$

Já Oswaldo Othon de Pontes Saraiva Filho ${ }^{455}$ entende que "só pode haver uma autêntica transação para extinguir litígio, quando surja, no seio de um procedimento de consulta, logo após a ciência da resposta, ou do processo administrativo ou judicial, alguma controvérsia sobre a mais correta interpretação jurídica da norma tributária e as consequências decorrentes; ou sobre a realidade dos fatos, se a norma tributária incidiu com exatidão sobre determinado fato, ou se o fato tributado não é aquele que a autoridade fiscal enxergou, ou seja, quando há dúvida da incidência correta da norma sobre fato certo ou situação”. O autor entende, assim, que o procedimento de consulta já seria suficiente à configuração do litígio necessário à formação da transação. Cita, para tanto, exemplos de campos férteis para transação havida antes da constituição do crédito tributário, tais como interpretação de atos praticados pelo contribuinte em planejamento tributário ou definição de base imponível de ITBI, ITCMD ou IPTU.

Heleno Taveira Torres, a seu turno, afirma que "materialmente, uma transação somente pode prosperar naqueles casos em que se reconheça efetiva incerteza, geradora de litígio nos quais a Administração, por si própria, reste impedida de alcançar,

\footnotetext{
${ }^{453}$ In Transação e arbitragem..., p. 115-116.

${ }^{454}$ Confira-se:

"Para que seja possivel a transação no Direito Tributário impõe-se tenha sido já instaurado o litígio, embora não se exija que este se caracterize pela propositura de ação judicial. Basta que tenha sido impugnado, pelo sujeito passivo da obrigação tributária, um auto de infração contra o mesmo lavrado. Ou por outra forma se tenha estabelecido uma pendência, dando lugar à instauração de um procedimento administrativo a ser julgado pelo órgão administrativo competente.

Realmente o que se impõe é que esteja configurado um litígio, a ser dirimido pelo órgão julgador administrativo, nos termos do procedimento próprio. Litígio atual, já instaurado, e não apenas anunciado por um dos sujeitos da relação, geralmente o Fisco. A pretensão do Fisco há ter sido formalmente manifestada. Só assim estará caracterizado o litígio que faz possível a transação destinada a sua terminação” (In Transação e arbitragem..., p. 116-117).

O mesmo entendimento é manifestado em A transação no Direito Tributário, p. 63.

${ }^{455}$ In A transação e a arbitragem..., p. 55.
} 
satisfatoriamente, a um resultado mais compatível com o princípio inquisitório da verdade material". 456

Fabio Brun Goldschmidt ${ }^{457}$ advoga pela possibilidade de transação tão somente para solução do conflito tributário já instaurado, nos termos do texto do CTN e ainda com amparo no texto aprovado como Modelo de Código Tributário para a América Latina, de 1966.

No mesmo sentido é a opinião de César García Novoa, que permite a transação também anteriormente à existência da obrigação tributária, ocasião na qual versará sobre conceitos jurídicos indeterminados. ${ }^{458}$

Dos aspectos acima ressaltados verifica-se, sem prejuízo de posições contrárias, haver entendimento doutrinário que vislumbra haver campo para que poder público e contribuinte dialoguem antes mesmo da existência do crédito tributário, na medida em que o acerto poderá interferir na própria formação do mesmo na qualidade de preventivo de litígio, na medida em que a legislação tributária abre campo para dúvidas e questionamentos que intervirão nos aspectos da regra matriz de incidência tributária.

O próprio Projeto de Lei 5.082/2009 estabelece que, além de a transação ser viável no curso de processo judicial ou em recuperação tributária, poder se dar administrativamente por adesão (art. 15).

Entende-se, assim, pela possibilidade de a transação operar-se em qualquer estágio em que haja controvérsia na seara tributária, a saber, antes da constituição do crédito tributário ou mesmo quando já constituída a obrigação do contribuinte, na medida em que os diversos aspectos da regra matriz de incidência se definem em momentos distintos ${ }^{459} \mathrm{e}$

\footnotetext{
${ }^{456}$ In Princípios da segurança jurídica e transação em matéria tributária. Os limites da revisão administrativa dos acordos tributários ,p. 307.

${ }^{457}$ In Arbitragem e Transação Tributária-Verificação de Compatibilidade.

${ }^{458}$ Mecanismos alternativos para la resolucion..., p. 104. Como afirma o autor, a transação preventiva tem por função prevenir a litigiosidade derivada de interpretações divergentes que podem surgir com relação a determinadas normas (tradução livre, cit., p. 105).

${ }^{459}$ A definição de certos aspectos da regra matriz, temporalmente, ocorre em momentos distintos a depender da natureza do tributo. Assim, quanto ao Imposto sobre a Renda (quer para pessoa física, quer para empresas), a definição da base de cálculo será feita após encerrado o período base de apuração, na medida em que se trata de fato gerador complexo. Já no caso dos tributos reais, a mensuração da base imponível poderá
} 
podem, assim, gerar campo fértil para acertamentos entre fisco e contribuinte na medida em que dúvidas instaurarão o litígio, sobretudo na medida em que se tratando de relação tributária, não há opção de qualquer das partes pela configuração do fato tributário 460 .

Por exemplo, o momento de quantificação da base imponível de tributos tais como IPTU ou ITBI (valor venal) ${ }^{461}$ pode gerar ampla discussão entre as partes antes mesmo que o lançamento tributário formalize sua constituição. Tal aspecto não afasta, no entanto, a divergência de posicionamento entre fisco e contribuinte a ensejar a existência de litígio.

Já em se tratando de IPI incidente no desembaraço aduaneiro pode haver divergência entre a classificação fiscal conferida pelo contribuinte ao produto e aquela que o fisco entende correta, sendo viável, nesse caso, que as partes discutam e alcancem a classificação mais adequada no caso concreto, determinando-se os eventuais acertos nos documentos de importação decorrentes e recolhimento de eventuais diferenças de exações incidentes. Ora, se há discordância quanto aos critérios declarados pelo contribuinte e aqueles que o fisco entende por corretos, há litígio instaurado a justificar seja firmada transação.

Quanto à possibilidade de a transação se operar quando já constituído o crédito tributário, não há dúvida, nos termos da própria definição legal, de que para que a transação se configure poderá haver litígio já instaurado ou a ser prevenido entre fisco e contribuinte.

Nesses casos, a transação se dará no âmbito administrativo, judicial ou arbitral, a depender da espécie do contencioso instaurado para questionamento quanto à exigibilidade do tributo. Temporalmente, em qualquer caso, será necessária, no entanto, que haja autorização legislativa para formulação do acordo, na medida em que a discussão quanto ao crédito tributário será levada a termo na ocasião. Em qualquer desses casos, será inequívoca a existência de litígio.

feita antes mesmo de qualquer materialização da hipótese de incidência pois o valor venal é definido pelas autoridades fiscais independentemente da ocorrência do fato gerador do ITBI.

${ }^{460}$ Sobre a vinculabilidade das partes em se tratando de relação jurídico-tributária, vide item I.2.3 acima.

${ }^{461} \mathrm{Ou}$ valor da transação, o que for maior no caso do ITBI. 


\subsubsection{A transação no curso da demanda judicial}

Cumpre investigar com cautela sobre a transação tributária no âmbito judicial na pendência de demanda já travada entre os sujeitos da relação jurídico-tributária. O Projeto de Lei 5.082/2009, ${ }^{462}$ assim como diversos programas de pagamento incentivado de tributos criados pelos fiscos, ${ }^{463}$ viabilizam a transação no curso da ação judicial pendente de julgamento e, a tal respeito, há precedentes de transações havidas em demandas judiciais em curso. Dentre os precedentes, localizam-se acordos devidamente homologados pelos magistrados, mas há também casos em que a transação tributária não foi albergada pelo Judiciário.

Por exemplo, tome-se a transação firmada na seara tributária não homologada pelo Tribunal de Justiça do Estado de Santa Catarina. ${ }^{464}$ Na ocasião, uma das razões de negativa da homologação residiu no fato de a discussão judicial posta a termo pelo acordo ter sido travada em sede de mandado de segurança, o que inviabilizaria, nos termos do entendimento dos julgadores, fosse firmado acordo para por fim ao litígio.

Não parece que a discussão acerca da espécie de demanda seja relevante para fins de afastar eventual possibilidade de se operar a transação no curso do processo judicial. Há muito a jurisprudência decidiu que em se tratando de matéria tributária, o Mandado de Segurança é cabível na medida em que não questiona lei em tese, sendo instrumento hábil para questionar aspecto legal da incidência tributária diante do caráter continuativo das relações entre fisco e contribuinte. ${ }^{465}$

De fato, na medida em que haja atendimento aos requisitos legais, não parece válido obstar que a transação firmada entre fisco e contribuinte seja homologada em juízo, sem que haja interferência no mérito do ato. ${ }^{466}$

\footnotetext{
${ }^{462}$ Há aspectos procedimentais específicos descritos nos artigos 30 e 31 do projeto, tais como vedação à transação firmada após advento de despacho que trate de admissibilidade de recursos especial e/ou extraordinário interpostos.

${ }_{463}$ Cite-se, por exemplo, o artigos $5^{\circ}$ e $6^{\circ}$ da Lei $11.941 / 2009$ ou $1^{\text {o }}$ do Decreto Paulista 58.811/2012.

${ }^{464}$ Nos autos da Apelação Cível em Mandado de Segurança n. 2006.032093-1/0002.00.

465 Tanto é assim que o Superior Tribunal de Justiça tem sumulada a possibilidade de se discutir o direito abstrato a compensação tributária (Súmula 212).

${ }^{466}$ Sobre o judiciário frente ao mérito da transação, vide III.2.8 infra.
} 
Outro aspecto interessante reside na necessidade de reexame necessário nos casos em que haja acordo firmado entre poder público (fisco) e contribuinte, nos termos do artigo 475 do Código de Processo Civil.

Se a transação implicar em mandamento jurisdicional parcialmente sucumbente sob a ótica do poder público, não parece viável afastar o duplo grau necessário, nos termos já decididos pelo Superior Tribunal de Justiça. ${ }^{467}$

Finalmente, importante destacar que em se tratando de processo judicial em curso, será essencial a participação do Ministério Público, ex vi do artigo 82, III do Código de Processo Civil, consoante entendimento jurisprudencial já proferido. ${ }^{468}$

No mais, a resolução da demanda judicial em razão de transação firmada entre fisco e contribuinte se afigura medida coerente com a noção de tributação participativa e contribui para a melhora no sistema atual de solução de controvérsias tributárias, na medida em que além de produzir solução autocompositiva ao conflito, encerrará discussão judicial que contribui para a situação calamitosa do nosso Judiciário.

Cumpre destacar que a modalidade de transação aqui tratada é distinta da conciliação judicial, eis que se trata de acordo firmado entre as partes fora do âmbito processual e levado a conhecimento do juízo para fins de extinção da lide. ${ }^{469}$

${ }^{467}$ Confira-se ementa:

"PROCESSUAL CIVIL. AGRAVO REGIMENTAL. LIMINAR. MEDIDA CAUTELAR. 1. Liminar concedida pela presença da fumaça do bom direito e do "periculum in mora". 2. Transação firmada entre Poder Público e particular, no curso de ação judicial, para pagamento de quantias mensais, tudo homologado pelo juiz, porém, sem o duplo grau de jurisdição obrigatório e desobedecendo expedição de precatório. 3. Agravo regimental improvido." (STJ. $1^{\mathrm{a}}$ Turma. AGRMC 200001008358. Rel. Min. JOSÉ DELGADO. J. 16/11/2000).

${ }^{468}$ Menciona-se a julgado oriundo do TRF da $4^{a}$ Região, APELAÇÃ̃ CÍVEL No 2000.04.01.097971-2/PR, que decretou a nulidade de acordo firmado pelo poder público por falta de intervenção do Ministério Público, nos termos do artigo 82, III do CPC.

${ }^{469}$ Sobre a conciliação judicial, Fabio Artigas Grillo traz as espécies de ação judicial nas quais poderia configurar-se, bem como aquelas nas não caberia a atividade conciliatória do juízo (Transação e justiça tributária, p. 227-232). 


\subsubsection{A transação no curso do processo arbitral}

Partindo da premissa a que chegou este estudo no sentido de que seria viável a submissão do conflito tributário à solução arbitral, cumpre averiguar se seria viável operarse acordo entre as partes para composição amigável do litígio, aplicando-se o disposto no artigo 28 da Lei da Arbitragem.

Nos termos do mencionado dispositivo da lei, o árbitro poderá, nos limites da convenção da arbitragem, homologar o acordo firmado entre as partes por sentença que conterá os mesmos efeitos da sentença que julgará o mérito da arbitragem.

Isso porque as partes poderão requerer que o acordo seja homologado por sentença com os mesmos efeitos da sentença judicial para as ocasiões nas quais, não havendo cumprimento voluntário de qualquer das partes, poderá ser instaurada execução de título judicial, nos termos do artigo 741 do CPC..$^{470}$

Inicialmente é importante esclarecer que a homologação do acordo a que as partes chegam fora do âmbito do tribunal arbitral não equivale à conciliação de que trata o artigo 21, parágrafo $4^{\circ}$ da Lei da Arbitragem, na medida em que a conciliação é mediada $e$ incentivada pelo juízo (judicial ou arbitral) e, contrariamente, no acordo firmado entre as partes a solução é alcançada somente pelos indivíduos em litígio em solução autocompositiva do conflito. Trata-se, assim, de transação firmada entre as partes, em termo que poderá ser levado a juízo.

Em sendo levada a juízo, Carlos Alberto Carmona salienta que "o legislador, ao asseverar que o árbitro, a pedido das partes, declarará que elas chegaram a um acordo, nada mais faz do que permitir ao árbitro uma atividade que, em última análise, é típica do exercício da jurisdição voluntária (homologação), tudo a reforçar a ideia da jurisdicionalidade da arbitragem". ${ }^{471}$

\footnotetext{
${ }^{470}$ Como visto no item III.2.8, trata-se de hipótese de busca do judiciário em decorrência da transação firmada entre as partes, para conferir obrigatoriedade ao cumprimento do acordo firmado.

${ }^{471}$ Arbitragem e processo..., p. 300.
} 
Carmona destaca, no entanto, que a atividade homologatória do árbitro no caso ora exemplificado guarda particularidade na medida em que haverá vinculação com a convenção da arbitragem: somente poderá haver homologação de acordo se a convenção assim permitir. $^{472}$

Tal requisito, por certo, é aplicável a toda e qualquer arbitragem, na medida em que a convenção arbitral confere poder e legitimidade ao tribunal arbitral que a decisão tomada seja mandatória entre as partes.

No caso da arbitragem tributária, adiciona-se requisito decorrente da estrita legalidade, que deverá não só nortear a firmação da convenção de arbitragem, mas também é pressuposto de validade da transação.

Assim, para que o artigo 28 da Lei de Arbitragem aplique-se à arbitragem tributária dois são os requisitos formais: a transação a ser firmada entre as partes deverá seguir os estritos limites legais da norma que norteie a transação e, adicionalmente, o tribunal arbitral $^{473}$ deverá ter competência para homologar o acordo firmado entre as partes fora do seio do tribunal formado, em previsão a vir expressa na convenção de arbitragem. ${ }^{474}$

Desse modo, conclui-se pela viabilidade de haver transação entre fisco e contribuinte antes ou depois da constituição do crédito tributário, bem como independentemente da pendência de demanda judicial ou arbitral já existente na qual litiguem fisco e contribuinte.

\subsection{Aspectos materiais transacionáveis}

Materialmente a transação poderá representar exclusivamente redução dos valores envolvidos na controvérsia tributária, tratar de aspectos materiais da regra matriz de incidência ou mesmo adentrar nos aspectos atinentes a interpretação legal.

\footnotetext{
${ }^{472}$ Arbitragem e processo, p. 301.

${ }^{473}$ Veja as anotações sobre o tribunal arbitral nos itens II.2.7.1 e II.2.7.1 supra.

${ }^{474}$ Sobre a convenção de arbitragem tributária, vide II.2.5 supra.
} 
A redução dos valores envolvidos na controvérsia tributária é já presente nas relações jurídicas que envolvem fisco e contribuinte, tal como exposto no item III, 1.6 acima, na medida em que comumente as pessoas jurídicas de direito público editam lei para criação e regulamentação de programas de pagamento incentivado de tributos.

O próprio Projeto de Lei 5.082/2009 estabelece que a transação nos moldes que pretende instituir poderá "dispor somente sobre multas, de mora e de ofício, juros de mora, encardo de sucumbência e demais encargos de natureza pecuniária, bem como valores oferecidos em garantia ou situações em que a interpretação da legislação relativa a obrigações tributárias seja conflituosa ou litigiosa" (artigo $6^{\circ}$ ), trazendo inclusive os limites quantitativos dos descontos viáveis de ser oferecidos.

Interessante destacar que o referido projeto de lei é expresso ao vedar a negociação quanto ao montante do tributo devido (art. $7^{\circ}$, I); ou seja, os descontos passíveis de negociação restringem-se, nos termos da regulamentação ainda pendente de análise, aos encargos incidentes sobre o tributo.

Quanto à possibilidade de a transação tratar de dúvidas acerca da melhor interpretação legal, tal como exposto com relação à arbitragem ${ }^{475}$ entende-se haver campo fértil para tanto, na medida em que ao tratar dos elementos da regra matriz tributária, a lei vez por outras é obscura ou traz fatos cuja averiguação é demasiadamente complexa, havendo campo fértil ${ }^{476}$ para que contribuinte e fisco acordem quanto ao melhor procedimento a ser adotado.

${ }^{475}$ Vide item II.2.2 supra.

${ }^{476}$ Confira-se, a esse respeito, o entendimento de RIBAS, Antonio Souza no sentido de que havendo campo para a transação tributária, as leis deverão tratar com cautela dos elementos essenciais que caracterizarão os elementos centrais da transação:

"Na defesa da legalidade a doutrina às vezes impõe uma interpretação com alcance de mitos como o de que a lei só admite uma única interpretação, pelo desenvolvimento de um silogismo perfeito, o que não é verdadeiro (assim como é um mito definir o valor efetivo da capacidade do contribuinte). Muitas vezes a linguagem na lei é dúbia, admitindo diferentes interpretações.

A possibilidade de existência de acordos ou transações em relação a essas zonas de incerteza, mesmo dentro da estrita legalidade, surge quando da aplicação da norma geral e abstrata ao caso concreto e visando a eventual solução de conflitos entre o particular e a administração tributária. No contexto de discussões e de dúvidas sobre os fatos jurídico-tributários em que não haja prova certa e direta, não há como se afirmar disposição de direitos, pelo que esses mecanismos alternativos podem contribuir, de forma significativa, para a eficácia da administração da justiça. A introdução de mecanismos negociais ou transacionais supõe um aumento objetivo da certeza dos fatos jurídico-tributários, mas que não pode colidir com a legalidade que rege o ordenamento tributário, uma vez que a segurança jurídica deriva da legalidade. Para tanto, tais técnicas 
Importante destacar que, nesses casos, não haveria necessariamente disposição de direitos por parte da Fazenda Pública na medida em que a adequada interpretação legal nem sempre resultará na apuração do tributo tal como feito pela Fazenda Pública no ato do lançamento.

Vale destacar que em linha com o disposto em seus artigos $6^{\circ}$ e $7^{\circ}$, I, o próprio Projeto de Lei 5082/2009, seu artigo 7o, III trata da impossibilidade de a transação tratar de matéria de fato ou de direito. Mais adiante, o projeto esclarece, no entanto, que "não constituem negociação do montante dos tributos as reduções que decorram do procedimento da transação, quanto à interpretação de conceitos indeterminados do direito ou à identificação e relevância do fato, aplicáveis ao caso, cujo resultado seja a redução de parte do crédito tributário" (artigo $7^{\circ}$, parágrafo $1^{\circ}$ ).

Ricardo Lobo Torres, ${ }^{477}$ ao tecer comentários sobre o anteprojeto de lei apresentado pela PGFN, o qual, para o autor, mais se aproxima de conciliação do que de transação propriamente dita, pois mediante concessões mútuas fisco e contribuinte podem evitar ${ }^{478}$ ou encerrar litígios, trata das possibilidades de transação para fins de preços de transferência. Como exemplo, o autor cita a dificuldade de se alcançar o preço de mercado para fins de cálculo do preço de transferência, considerando também a problemática de quais fatores devem ser considerados para fins de definição do preço parâmetro, tais como política governamental referente a salários e incentivos devem ou não ser consideradas, o autor entende se tratar de campo fértil para incidência da transação (e também da conciliação).

Outro exemplo acerca de questões decorrentes de interpretação legal que poderiam ser satisfatoriamente transacionáveis reside na classificação fiscal de mercadorias, necessária à imputação das bases imponíveis do Imposto sobre Produtos Industrializados e

transacionais podem ser entendidas pelos elementos essenciais à configuração da obrigação tributária e devem estar contempladas expressamente na lei. A eventual transação pode estar orientada para evitar o conflito em sentido estrito" (Arbitragem como meio alternativo na solução de controvérsias tributárias).

${ }^{477}$ In Transação, conciliação e processo tributário administrativo equitativo..., p. 90-91.

${ }^{478}$ Por tal afirmação, o autor já se posiciona no sentido de admitir a transação preventiva. 
do Imposto de Importação, e por vezes também do ICMS ${ }^{479}$ Isso porque a complexidade das regras de classificação fiscal abre margem de dúvida e até mesmo controvérsias entre fisco e contribuinte acerca da posição tarifária adequada. É possível, inclusive, que seja necessária a avaliação de perícia técnica, por vezes executada por técnicos da Receita Federal do Brasil, para que se alcance a classificação mais adequada ao produto. Nesses casos, entendemos haver campo fértil para possível transação entre fisco e contribuinte, o que poderá evitar prolongadas controvérsias e também futuros litígios.

Vale, por oportuno, mencionar que, diferentemente do acima defendido, na Alemanha o acordo tributário somente poderá versar sobre questão de fato (sob pena de ofensa ao princípio local da legalidade) e corresponde a mecanismo de cooperação entre Administração pública e contribuinte. ${ }^{480}$ Entende-se, no entanto, que no sistema brasileiro a possibilidade de a transação tratar de dúvida quanto a melhor interpretação legal não afasta o caráter cooperativo entre fisco e contribuinte, na medida em que a transação sempre representará diálogo entre os sujeitos envolvidos na relação jurídico-tributária.

Quanto a aspectos objetivos da regra matriz de incidência, a transação igualmente possui campo fértil para prosperar. Por exemplo, na definição de base imponível do Imposto sobre a Renda, há controvérsias acerca do tratamento contábil de determinadas receitas das pessoas jurídicas que poderiam ser solucionadas mediante transação acerca da postura a ser adotada pelo contribuinte. Ou ainda, poderia haver acordo entre fisco e contribuinte para fins de conferir direito a determinado crédito de PIS/COFINS para os contribuintes que apurem as contribuições pelo regime não cumulativo, pois a natureza das aquisições por vezes geram dúvidas quanto ao tratamento fiscal adequado de tributos destacados em nota fiscal.

Em termos quantitativos, vale trazer o exemplo da conciliação italiana, a qual somente poderá tratar do valor do tributo, não podendo adentrar no mérito da obrigação tributária, sob pena de ofensa à indisponibilidade do crédito tributário. ${ }^{481}$

\footnotetext{
${ }^{479}$ Saliente-se, nesse sentido, a Resolução do Senado Federal, 13/2012, que instituiu alíquota única do ICMS para transações interestaduais e excluiu da regra produtos que, em termos práticos, possui alíquota diferenciada para fins de incidência do Imposto de Importação, em regra a ser expedido pelo Camex.

${ }^{480}$ Carlos Yuri Araújo Moraes, op. Cit., p. 495-496.

${ }^{481}$ Nesse sentido, Baldassarre Santamaria, Diritto Tributario, p. 494.
} 
Desse modo, materialmente, há campo fértil para a transação tributária não só para composição de litígios após já instaurado o contencioso entre físco e contribuinte ou mesmo quando já constituído o crédito tributário, mas se averigua campo fértil para que a transação opere também nas situações em que a legislação de regência deixa margem para acertamentos entre as partes.

\subsection{A constituição de crédito em favor do contribuinte a partir da transação}

Imprescindível, ao tratar de aspectos materialmente transacionáveis, investigar se seria viável que a transação constitua crédito em favor do contribuinte contra o fisco, nos termos do artigo 165 do CTN (repetição de indébito tributário). A transação poderá reduzir o valor do crédito tributário e trazer novas condições para seu adimplemento, sempre nos limites da lei. Poderia também constituir crédito em favor do contribuinte, reconhecendo o indébito tributário?

Diferentemente do que se passa com a arbitragem, ${ }^{482}$ o termo da transação é ato decorrente de manifestação de vontade das partes envolvidas. Ou seja, fisco e contribuinte manifestam suas vontades, anuem quanto à renúncia recíproca de direitos e, a partir de então, se verifica o cumprimento de novas obrigações a serem adimplidas por ambos para terminação da controvérsia.

Enquanto na arbitragem a decisão é proferida por terceiro (árbitro ou tribunal) imparcial e estranho ao litígio, os termos da transação são definidos pelas partes envolvidas e a elas se aplica, representando uma solução autocompositiva produzida mediante manifestação de vontade das partes. Não parece que haveria campo fértil para que no termo de transação haja reconhecimento do indébito tributário em favor do contribuinte, na medida em que seria necessário para tanto que se constituísse crédito em desfavor do poder público.

A transação, nessas condições, não parece que poderá constituir qualquer montante a ser restituído pelo físco ao contribuinte, pois tal verificação somente poderá ser feita com exatidão e precisão de forma que não haja, em espécie alguma, indevido dispêndio de

${ }^{482}$ Cf. análise feita no item II.1.6 acima. 
recursos. O fisco poderá renunciar a crédito tributário, mas não poderia constituir, em termo de acordo, débito a ser adimplido ao contribuinte.

Justamente para hipóteses em que o próprio contribuinte apure crédito decorrente de indébito tributário e que a fiscalização anua com o recolhimento a maior, há previsões nas normas expedidas pelos diversos braços do fisco brasileiro expressas de meios para que o contribuinte possa pleitear, na esfera administrativa, seja apurado e averiguado eventual indébito, a originar pleitos de restituição propriamente dita ou mesmo compensação com tributos vincendos, desde que administrados pelo mesmo ente tributário.

De outra monta, em havendo prévio e inequívoco reconhecimento de indébito tributário pendente de recebimento pelo contribuinte, a transação poderá decretar a compensação de tal montante com débitos pendentes, como forma de realizar encontro de contas e extinguir ambas as obrigações existentes.

O Estado do Espírito Santo, em 2002, editou lei ${ }^{483}$ autorizando a Procuradoria do Estado a firmar acordos com contribuintes que possuíam crédito contra o Estado. Tratavase, por certo, de autorização para compensação com utilização de crédito já reconhecido, e não de termo de transação a reconhecer o crédito em favor do contribuinte. ${ }^{484}$ A diferença pode ser sutil numa impressão preambular, mas avaliando-se com a devida profundidade notar-se-á que o reconhecimento do crédito do contribuinte, na primeira hipótese, era pressuposto do ato de compensação e, na segunda, seria objeto da transação.

${ }^{483}$ Confira-se o artigo $7^{\circ}$ da Lei Estadual 7.249/2002:

Fica autorizada a Procuradoria Geral do Estado a firmar contratos com contribuintes, transacionando a extinção de créditos tributários, tendo por contrapartida a assunção e extinção de débitos estaduais em valor equivalente.

${ }^{484}$ O Superior Tribunal de Justiça chegou a analisar casos decorrentes da legislação e entendeu que a autorização legal prescindia da análise da conveniência do ato por parte dos agentes estatais. Confira-se: RECURSO ORDINÁRIO. MANDADO DE SEGURANÇA. COMPENSAÇÃO DE DÉBITO TRIBUTÁRIO COM PRECATÓRIO JUDICIAL. LEI CAPIXABA N. 7249/02 (ART. $\left.7^{\circ}\right)$. DIREITO LÍQUIDO E CERTO INEXISTENTE.

1. A autorização contida no art. 7 o da Lei Estadual 7249/2002 para que a Procuradoria-Geral do Estado transacionasse, mediante contratos com os contribuintes de créditos tributários, não implicou na obrigatoriedade de efetuar a transação sem exame da sua oportunidade e conveniência. 2. Os valores contidos em precatórios judiciais, sujeitos à ordem de preferência do pagamento e que, por isso mesmo, não apresentam liquidez imediata a fim de possibilitar sua compensação com débitos fiscais vencidos ou vincendos. - 3. Inexistência do alegado direito líquido e certo da impetrante. - 4. Recurso ordinário improvido. (ROMS 200400507965. $2^{\text {a }}$ Turma. FRANCISCO PEÇANHA MARTINS. DJ DATA:21/11/2005 PG:00172). 
Desse modo, na medida em que seu caráter autocompositivo não fornece a segurança e imparcialidade necessárias para que se constitua obrigação pecuniária contra o poder público, entende-se pela inviabilidade de o termo de acordo (transação) constituir crédito em favor do contribuinte, decorrente de indébito tributário, a despeito de a transação poder viabilizar compensação de crédito já constituído com obrigações vincendas do sujeito passivo da relação jurídico tributária.

\section{5. Âmbito para se processar a transação}

A lei que tratar da transação necessariamente disporá sobre as autoridades competentes a regulamentar e processar os trâmites necessários à conclusão das obrigações a serem previstas no termo de acordo até que se opere a extinção das obrigações.

De todo o modo, parece claro que a transação tributária necessariamente será processada no seio da administração fiscal respectiva, na medida em que a autoridade competente para firmá-la necessariamente será agente público munido de autorização legal.

A própria legalidade que norteia a transação ${ }^{485}$ necessariamente demandará que a regulamentação do procedimento disponha sobre a forma de conclusão das negociações e das obrigações a serem pactuadas, bem como precisará tratar das formas para solucionar aspectos controversos entre as partes, surgidos no curso da negociação, ou mesmo adimplemento das obrigações mútuas.

Poderá haver, nesse sentido, a criação de um órgão especial da administração fazendária respectiva apenas para tratar da transação, cuidar da sua formação, processamento e adimplemento pelos envolvidos. Importante destacar que cada ente tributário será competente para criar suas regras próprias e cada espécie de transação terá sua regulamentação. Assim, uma lei que traga previsão geral sobre a transação poderá conferir aos conflitos dela resultantes tratamento diferenciado do que uma lei específica que trate pontualmente de programa incentivado de pagamento de tributos. ${ }^{486}$

\footnotetext{
${ }^{485}$ Cf. III.1.4 supra.

486 Confirme item III.1.6 supra, entendemos pela natureza transacional dos programas incentivados de pagamento de tributos.
} 
O Projeto de Lei 5.082/2009, por exemplo, trata da criação da Câmara-Geral de transação e conciliação (artigos 46 e seguintes), com competência para não só decidir sobre as modalidades de transação, mas também regulamentar as negociações e solucionar incidentes surgidos entre as partes.

O essencial, seja mediante criação de órgão especial específico, seja com a atribuição de competência para órgão e entidades já existentes, é que haja detalhada previsão legal acerca de aspectos inerentes à transação, a saber: competência para transacionar, objeto da transação, formalização do acordo, obrigações transacionáveis, elementos renunciáveis pelo fisco, forma de solução de incidentes e conflitos surgidos entre as partes.

\subsection{A extinção do crédito tributário frente à transação}

O CTN traz as taxativas hipóteses de suspensão (artigo 151) e extinção (artigo 156) do crédito tributário e na atual redação do Codex há menção à transação tão-somente em se tratando de condição extintiva do crédito tributário (inciso III).

Em se tratando de transação posterior à constituição do crédito tributário, Hugo de Brito Machado ${ }^{487}$ salienta que nem sempre a transação extinguirá o crédito tributário, na medida em que poderá conceder novo prazo ou condição para pagamento do tributo, o que, a seu turno, terá o condão de extinguir o crédito tributário. A transação, na verdade, extinguirá o litígio e o seu adimplemento pelo contribuinte (mediante pagamento, compensação ou outra forma de extinção já tipificada pelo $\mathrm{CTN})^{488}$ será meio hábil a extinguir o crédito tributário.

${ }^{487}$ In Transação e arbitragem no âmbito tributário, p. 117.

${ }^{488}$ Nesse sentido, vale transcrever Oswaldo Othon de Pontes Saraiva Filho: quando a transação, por si só, não extingue o litígio e o crédito tributário, servindo apenas como instrumento, emerge, mesmo que simultâneo, o aparecimento de outras figuras como o parcelamento, ou a concessão de benefícios fiscais, anistia, remissão, todos dependentes de lei tributária específica, ou de lei que trate do respectivo tributo ou contribuição nos termos exigidos pelo artigo 150, par. $6^{\circ}$, da Constituição da República, sendo, no caso, ainda mais insuficiente a eventual existência de lei geral, ou que o legislador delegue à autoridade administrativa a atribuição de legislar; ou mesmo confira a ela poderes demasiadamente discricionários, para a realização da transação. (A transação e a arbitragem..., p. 69). 
Heleno Taveira Torres, ${ }^{489}$ da mesma forma, entende que a transação não extingue o crédito tributário, na medida em que é "simples mecanismo de resolução de conflitos". O que terá o condão de extinguir o crédito tributário será o pagamento do montante acordado entre as partes, por exemplo.

Diferentemente do verificado com relação à arbitragem, ${ }^{490}$ nos parece que com relação à transação não é necessário que haja previsão no sentido de ser o ato capaz de extinguir o crédito tributário. Isso porque, na qualidade de ato por meio do qual há concessões mútuas, a transação implicará no cumprimento de determinada obrigação pelo contribuinte e, somente após, operar-se-á a extinção do crédito tributário.

Desse modo, alinhando-nos a doutrina que já desafiou o assunto, entendemos pela desnecessária previsão do art. 156, III do CTN para fins de que a transação seja apta a extinguir o crédito tributário pois o adimplemento da obrigação pelo contribuinte terá o condão de fazê-lo nos termos das hipóteses já elencadas no Codex.

Outrossim, nos casos em que a transação se opere em situações nas quais ainda não há crédito tributário constituído, por exemplo para fins de apuração de preço parâmetro relativo a cálculo de ajuste da base de cálculo do IRPJ e da CSLL em se tratando de preços de transferência, não haverá necessidade de que haja extinção do crédito tributário em decorrência do ato. Em verdade, nesse caso a transação operará diretamente na formação do mencionado crédito tributário preventivamente ao litígio - e deverá ser levada em eventual julgamento de litígio entre as partes, decorrentes de fato objeto da transação.

${ }^{489}$ In Princípios da segurança jurídica e transação em matéria tributária. Os limites da revisão administrativa dos acordos tributários, p. 305.

Confira-se o entendimento mais adiante manifestado pelo Professor:

Ora, dizer.que a transação "extingue" o crédito tributário nada tem a ver com o "pagamento" desta eventualmente decorrente. Decerto que tal menção no rol das causas extintivas das obrigações tributárias só tem cabimento se entendermos a transação no contexto da extinção da pretensão tributária sobre o quanto foi concedido pela Administração tributária, com respeito às concessões (recíprocas) dos contribuintes. (p. 310)

Em análise distinta o Professor manifestou no mesmo sentido sua opinião:

A transação, per se, não extingue o crédito; é simples mecanismo de resolução de conflitos que se presta para pôr fim ao litígio, mediante composição das partes. Nos termos do acordo a que cheguem as partes, o processo será decidido. Com base na decisão, a autoridade responsável pelo lançamento emitirá novo ato administrativo, para que o contribuinte efetue o pagamento dentro do vencimento. O pagamento, sim, extinguirá o crédito; não a transação, pura e simplesmente. (In Transação e arbitragem.., p. 58).

${ }^{490}$ Vide II.2.10 acima. 


\subsection{A suspensão da exigibilidade do crédito tributário}

Em se tratando da suspensão do crédito tributário, no entanto, para que a transação possa ser efetiva, será necessário alterar a redação do artigo 151 do CTN para que esteja elencada dentre as hipóteses suspensivas da exigibilidade do crédito tributário. Isso porque desde o momento em que seja firmada a transação até o efetivo e completo adimplemento pelo sujeito passivo do quanto acordado, é essencial que haja segurança de que atos constritivos não serão adotados (desde que não haja mora, por certo).

Na atividade empresária é essencial que seja viabilizada a emissão de certidão positiva de débitos com efeitos de negativa (nos termos dos artigos 205 e 206 do CTN), o que somente seria viável desde que a transação suspendesse a exigibilidade do crédito tributário.

Assim, a despeito de não se entender pela necessidade de previsão expressa no artigo 156 do CTN para fins de que a transação seja elencada dentre as condições extintivas do crédito tributário, para que a transação seja efetiva é importante que passe a ser condição suspensiva da exigibilidade do crédito tributário (CTN, artigo 151), de forma que haja segurança e amparo necessários ao contribuinte até que seja integralmente adimplida a obrigação decorrente do termo de acordo firmado com o fisco.

Interessante mencionar que o Projeto de Lei 5.082/2009 prevê que a formalização do acordo nos termos e condições previstos, determinará a suspensão do curso da ação executiva proposta para cobrança do débito fiscal objeto de negociação (artigo 28, parágrafo $1^{\circ}$ ). Não traz, no entanto, menção à suspensão da exigibilidade do crédito. 


\subsection{Revisão judicial do acordo}

É certo que qualquer transação firmada entre poder público e particular deve pautar-se nos princípios que regem os atos dos administradores públicos, sob pena de ser decretada sua nulidade. Assim, transação que não siga estritamente a legalidade, moralidade, razoabilidade e na qual que haja indevido conluio entre as partes ou mesmo se comprovado ter havido indevida vantagem do particular ou conluio entre as partes, a transação poderá - e deverá - ser revisada judicialmente ${ }^{491}$ e ter seu mérito invadido.

A título exemplificativo, vale mencionar que a conciliação extrajudicial italiana tem caráter definitivo $^{492}$ e tal prerrogativa parece ser também necessária a efetividade da transação tributária extrajudicial. No entanto, não há como afastar a tutela jurisdicional nas hipóteses em que irregularidades insanáveis se verifiquem, tais como conluio entre as partes para prática de transação ilícita.

No sistema britânico, ${ }^{493}$ o acordo somente poderá ser questionado em determinadas circunstâncias, dentre as quais os autores ressaltam em caso de fraude ou interpretação equivocada dos fatos, erro incorrido por ambas as partes envolvidas, erro provocado por uma das partes, incorreta interpretação da lei ou indevida influência econômica.

Acerca de eventual vantagem indevida percebida em decorrência de transação, importante destacar que o Superior Tribunal de Justiça entende necessária ação própria para apurar eventual irregularidade, antes de decretar a nulidade da transação ${ }^{494}$ Ou seja, eventuais prejuízos ao Erário deverão ser apurados pelas vias próprias.

491 O Projeto de Lei 5.082/2009 traz as seguintes possibilidade de nulidade da transação: ausência de requisitos formais ou materiais, desrespeito aos limites materiais legais, existência de coisa julgada anterior ao acordo, ocorrência de prevaricação, concussão, corrupção passiva, dolo, fraude, simulação, erro essencial quanto à pessoa ou ao objeto (art.12).

${ }^{492}$ Baldassare Santamaria, op. Cit., p. 495.

493 Cf. BLAKE, Susan, BROWNE, Julie e SIME, Stuart, in A practical approach to Alternative dispute resolution, p. 489.

${ }^{494}$ Confira-se ementa do julgado:

ADMINISTRATIVO. PROCESSUAL CIVIL. EMBARGOS DE DIVERGÊNCIA. REJEIÇÃO.

1. Não merecem conhecimento embargos de divergência que nãodemonstram dissídio jurisprudencial entre o acórdão embargado e os apresentados para confronto.

2. Desapropriação. Transação. Possibilidade. Apelação em segundo grau que não foi conhecida, sem adentrar no mérito do que as partes ajustaram.

3. Reconhecimento do Poder Público, em tais casos, de firmar transação. Homologação judicial.

4. Dano ao patrimônio público, se apurado, há de ser investigado e decidido em ação própria. 
Importante outrossim mencionar que a administração pública não poderá unilateralmente pretender rever o ato administrativo que corporifica a transação sob a pretensão de formular ato mais benéfico ao poder público, na medida em que a bilateralidade do ato e o custo da cessão de interesses e prejuízos pessoais inviabilizam tal pretensão. $^{495}$

É importante destacar que enquanto ato jurídico ${ }^{496}$ perfeito, a transação não poderá ter seu mérito analisado pelo Judiciário, consoante jurisprudência que ensejou a edição da Súmula Vinculante No. 1 do STF, que trata de FGTS e segundo a qual "ofende a garantia constitucional do ato jurídico perfeito a decisão que, sem ponderar as circunstâncias do caso concreto, desconsidera a validez e a eficácia de acordo constante de termo de adesão instituído pela Lei Complementar n 110/2001”.

Aspectos essenciais a serem verificados na transação tributária são a estrita legalidade e capacidade do agente ${ }^{497}$ para firmar a transação, na medida em que tais aspectos podem invalidar o ato. O acordo firmado na seara tributária, para ser formal e materialmente válido, deverá atender plenamente aos requisitos legais, sob pena de poder ser questionado judicialmente em seu mérito.

5. Embargos não conhecidos (EREsp 70402. Primeira Sessão. Rel. Ministro JOSÉ DELGADO. DJ 28/02/2000).

${ }^{495}$ Nesse sentido, Heleno Taveira Torres, Princípios da segurança jurídica e transação em matéria tributária. Os limites da revisão administrativa dos acordos tributários, p. 313.

496 Nesse sentido, vale transcrever o entendimento de Heleno Taveira Torres (In Princípios da segurança jurídica e transação em matéria tributária, p. 311):

De fato, quando se viola o ato jurídico perfeito dos acordos realizados em transações legais específicas, não se viola apenas um acordo, isoladamente, mas viola-se todo o ordenamento jurídico, toda a razão de ser do devido processo legal e dos procedimentos administrativos, expõese à dúvida a função do estado no seio da sociedade e lança-se a segurança jurídica a uma condição de princípio meramente formal e episódico do ordenamento jurídico.

${ }^{497}$ Sobre competência para transacionar, vide III.2.1 supra. 
Desse modo, não se verificando quaisquer das situações excepcionais ${ }^{498}$ que trariam legitimidade para se invalidar o acordo, não seria lícito ao Judiciário sobrepor-se à vontade das partes para adentrar ao mérito do termo anuído entre os envolvidos no conflito e interferir no termo de transação.

Adicionalmente à hipótese de interferência judicial para se anular termo transacional irregular ou mesmo rever seu mérito, vale tratar da possível atuação judicial para garantir o cumprimento do acordo. Como salientam Susan Blake, Julie Browne e Stuart Sime, ${ }^{499}$ num processo de decisão não adjudicativo, se as partes resolveram seu litígio, é porque anuíram para tanto num contrato ou compromisso. O cumprimento do acordado tem fundamento justamente no quanto restou decidido. Alternativamente ao voluntário cumprimento do acordo, as partes poderão buscar o Judiciário para enforcement da decisão.

O Judiciário ${ }^{500}$ pode, desse modo, vir a ser necessário na hipótese de qualquer das partes não adimplir com os termos do acordo, situação na qual o poder de polícia será necessário para fins de coerção quanto ao cumprimento dos termos acertados. Nesse tocante, vale destacar o entendimento de Heleno Taveira Torres ${ }^{501}$ no sentido de que o princípio da boa-fé objetiva, da confiança legítima e da moralidade afastariam a possibilidade de descumprimento do acordo.

\footnotetext{
${ }^{498}$ Importa destacar situação na qual, a despeito da edição de lei autorizando o Município de Içara a firmar acordo com o contribuinte (Lei 2.411/2007), tendo sido firmado termo de acordo por meio do qual as partes anuíram que o contribuinte poderia excluir valores com custo de material e mão de obra da base imponível do ISS, matéria sub judice quando da formação da transação, o acordo foi anulado e não homologado pelo Tribunal de Justiça quando do julgamento da Apelação Cível em Mandado de Segurança n. 2006.0320931/0002.00.

Oportuno transcrever, do voto condutor do acórdão, que "as ações mandamentais tem por pressuposto direito líquido e certo violado por ato ilegal, razão pela qual mostra-se inviável a homologação de composição, eis que representaria dar origem a título executivo contra entidade pública, o que extrapola os objetivos do writ, especialmente tendo em conta que os autos versam acerca da incidência ou não de tributo, o que depende exclusivamente da lei, e não da vontade das partes." (...) "Em se tratando de direito indisponível, incabível se torna a transação, conforme o artigo 841 do CC, motivo pelo qual se reconhece o pleito como desistência fosse. Mutatis mutandis, "somente os direitos disponíveis são passíveis de renúncia. Assim, os direitos de personalidade, como a vida, a integridade física, a honra, os direitos que integram o patrimônio Público e os direitos difusos são indisponíveis [...]".

${ }^{499}$ In A practical approach to Alternative dispute resolution, p. 486.

${ }^{500}$ Válido destacar que no direito britânico o Judiciário deve ser noticiado quanto a qualquer acordo firmado entre os jurisdicionados (cf. entendimento de Susan Blake, Julie Browne e Stuart Sime, A practical approach to alternative dispute resolution, p. 337-338).

${ }^{501}$ In Princípios da segurança jurídica e transação em matéria tributária.
} 
Na hipótese de a solução pactuada não ser voluntariamente cumprida por qualquer das partes, o Judiciário poderá ser procurado para fins de coagir as partes ao seu cumprimento, mas nesse caso o mérito do acordo não será revisado - salvo, por certo, hipóteses excepcionais que invalidem a transação. Eventuais medidas coercitivas que venham a ser adotadas para cumprimento do acordo - mormente mediante atuação do Judiciário - terão fundamento justamente no fato de a solução ter sido livre e voluntariamente pactuada entre as partes e, portanto, haver fundamento e validade para exigir-se o cumprimento. ${ }^{502}$

Quanto ao cumprimento da transação por parte do poder público, é essencial que haja disposição legal acerca dos trâmites administrativos decorrentes do acordo para fins de que haja pleno cumprimento. Especialmente na seara tributária, os representantes legais das pessoas jurídicas de direito público atuam em independência e de forma não vinculada às autoridades fiscais responsáveis pelo lançamento tributário e, nesse passo, é primordial que haja exata previsão legal a conferir efetividade ao acordo, sob pena de restar inócuo o resultado o ato jurídico formado. Nesse tocante, Heleno Taveira Torres ${ }^{503}$ salienta que há plena vinculação do agente que atuará na transação à lei que a regulamenta, sem esquecer de que os atos da autoridade administrativa não devem violar a Constituição Federal.

Já na eventualidade de o contribuinte não adimplir com suas obrigações pecuniárias objeto do acordo, os valores não pagos poderão ser inscritos em dívida ativa para oportuna cobrança executiva fiscal, sem prejuízo de demais penalidades eventualmente impostas pela legislação de regência ${ }^{504}$ do ato.

Desse modo, o mérito do acordo poderá ser revisto judicialmente nas hipóteses de invalidade do ato, mas jamais para revisar o mérito dos termos acordados. Outrossim, o Judiciário poderá ser necessário nas hipóteses de ser necessária aplicação de poder coercitivo para fins de cumprimento do acordo por qualquer das partes ou mesmo para continuidade da discussão acerca de aspectos do conflito não transacionados.

\footnotetext{
${ }^{502}$ In A practical approach to Alternative dispute resolution, p. 486.

${ }^{503}$ In Princípios da segurança jurídica e transação em matéria tributária. Os limites da revisão administrativa dos acordos tributários, p. 309.

${ }^{504}$ Tomando-se a exemplo os programas de anistia fiscal constantemente providenciados no Brasil, sugere-se que a lei que tratar da transação afaste eventuais benefícios havidos pelo contribuinte no momento do acordo nas situações de inadimplemento (vide, por exemplo, Lei n. 11.941/2009).
} 


\subsection{Da possibilidade de se exigir, como condição da transação, que o contribuinte renuncie a discussões judiciais, administrativas e arbitrais do crédito tributário}

Vale aqui trazer a controvérsia jurisprudencial surgida em decorrência de previsões de programas de parcelamento de tributos, transação que são, que exigem, como condição para adesão e aproveitamento dos descontos, que os contribuintes renunciem a discussões judiciais e administrativas acerca do crédito tributário a ser inserido no programa e pago pelo contribuinte com os descontos oferecidos pelo fisco. Há entendimento jurisprudencial no sentido de que, ao aderir aos programas, o contribuinte anui com todas as condições impostas pelo legislador, exercendo sua opção pelo aproveitamento do programa. ${ }^{505}$

Há, no entanto, entendimento doutrinário no sentido de que a mera anuência a tais requisitos seria contrária à ordem constitucional tributária vigente e tal ato violaria a autonomia da vontade, que não se pode negar aplicabilidade e validade mesmo no direito tributário. James Marins ${ }^{506}$ esclarece que a exigência legal de renúncia à discussão acerca do crédito tributário deve ser avaliada com mais cautela na medida em que o contribuinte poderia optar validamente pelo parcelamento ainda que pretenda permanecer ativa discussão judicial do crédito tributário e, ademais, faria sentido "discutir e parcelar simultaneamente,. 507

A verificação de validade do mérito da manifestação de vontade do contribuinte e também da própria fiscalização (a ser manifestada em total atendimento à estrita legalidade) poderão, em situações excepcionais, ser avaliadas como formas de conferência da validade dos atos, a prevalecer o entendimento doutrinário que desafia a jurisprudência

${ }^{505}$ Nesse sentido, vide AC 2000.72.04.000053-4, TRF 4 ${ }^{\mathrm{a}}$ Região, j. 12.09.2000): “A adesão ao programa REFIS é facultativa e quem a ele adere sujeita-se às condições impostas pela Lei No. 9.964/2000, sem reservas".

${ }^{506}$ in Direito processual tributário brasileiro..., p. 333-334.

${ }^{507}$ Vale transcrever a inquietação formulada pelo jurista acerca da problemática:

Mesmo que se pretenda examinar o problema sob a ótica das transações, acordos ou outros instrumentos judiciais e extrajudiciais e de sua validade no Direito Tributário ou sob o prisma da eficácia da autonomia da vontade no âmbito do fenômeno tributário, não há espaço para soluções simplistas. Há sério risco de ignorância acerca das consequências da relativização ou flexibilização do princípio da legalidade sem reflexão mais profunda, não apenas do ponto de vista do contribuinte, mas também do ponto de vista da estrita legalidade como garantia da própria relação jurídica tributária (Direito processual tributário brasileiro, p. 334). 
que aceita plenamente a condição prévia de desistência, pelo contribuinte, de qualquer discussão judicial ou administrativa acerca do crédito tributário a ser objeto de acordo.

Finalmente, vislumbra-se a possibilidade de o acordo tratar apenas parcialmente da controvérsia, ocasião na qual poderá haver continuidade da discussão judicial ou mesmo administrativa acerca do aspecto litigioso não solucionado.

Novamente trazendo a conciliação italiana como paradigma, vale destacar que Gianni de Luca $^{508}$ ressalta, nesse sentido, que caso a conciliação solucione apenas parcialmente da controvérsia, continuará a discussão para solução dos aspectos não transacionados.

${ }^{508}$ Compendio di Diritto Tributario, p. 243. 


\section{CONCLUSÃO}

O objetivo da presente dissertação de mestrado foi o de, constatada a ineficiência do sistema atualmente posto à disposição dos sujeitos envolvidos na relação jurídicotributária a partir de uma análise fática das discussões judiciais travadas entre fisco e contribuinte para solução de controvérsias tributárias, sustentar a viabilidade processual da adoção da arbitragem e da transação.

Estudos sobre a natureza dos processos judiciais em andamento apontam a expressiva presença daqueles que cuidam de controvérsias tributárias. Levantamento realizado pelo Supremo Tribunal Federal mostra que as ações tributárias e previdenciárias representavam $15,47 \%$ do total dos recursos em andamento perante a Corte até setembro de 2009 e no ano de 2012, esse percentual alcançou 22,31\% dos recursos autuados no STF. Ainda, verificou-se aumento da parcela de recursos tributários: no ano 2000 representavam $5,76 \%$ do total dos recursos em andamento; já em 2008, as ações tributárias representavam $20,94 \%$ dos recursos e, em $2011,10,63 \% .^{509}$

Em contrapartida e a despeito dos custos envolvidos, a efetividade da solução adjudicada judicial dos conflitos tributários não se mostra plenamente satisfatória, como se verifica, por exemplo, a partir do percentual de recuperação dos valores inscritos em dívida ativa da União Federal: no ano de 2006, o valor recebido via cobrança judicial atingiu aproximadamente $0,6 \%$ do crédito total acumulado. Mencione-se, outrossim, análise feita pelo IPEA/CNJ, a qual constatou a ineficácia das ações executivas fiscais ao comparar os custos envolvidos à efetividade do procedimento.

\footnotetext{
509 Fonte: http://www.stf.jus.br/portal/cms/verTexto.asp?servico=estatistica\&pagina=pesquisaRamoDireito, acesso em 01.11.09 e em 09.10.12.
} 
Considerando as características do Estado na atualidade, cada vez mais voltado ao seu bom relacionamento com os administrados e superada a posição de mero coadjuvante na atividade econômica do país, concluí-se que aguardar por anos a fio por uma decisão judicial que, muitas vezes, sequer detém o conhecimento técnico específico para tratar de determinada relação, não atende aos anseios sociais e também econômicos, mormente nas relações tributárias.

É justamente nesse contexto que a arbitragem, mecanismo adjudicatórios de base consensual, se mostra solução adequada a determinadas controvérsias, pois a especialidade dos árbitros pode ser atrativa tanto ao mérito da decisão quanto ao destino da controvérsia, somando-se ainda os benefícios da notória agilidade do julgamento dos procedimentos arbitrais. De outro lado, a transação, na qualidade de método autocompositivo de solução de controvérsias, adéqua-se à atual demanda da sociedade por uma administração pública mais transparente e participativa, sempre chamada a mostrar accountability e responsividade.

No entanto, em se tratando de controvérsia tributária, a manta da indisponibilidade do interesse público pautava barreira inicial a ser superada, até que se atingisse maturidade para tratar da disponibilidade do crédito tributário.

De fato, o que é indisponível é o dever do Estado de agir no interesse da sociedade e de acordo com os princípios constitucionais vigentes. Para tanto, poderá ser necessário que se disponha de determinado bem - desde que sua natureza assim permita -, com vistas a uma solução mais adequada e menos gravosa à sociedade para determinado conflito, atendendo-se assim à eficiência, razoabilidade, proporcionalidade e moralidade, elevadas a princípios constitucionais. O tratamento adequado ao conflito, nesse diapasão, deverá ser aquele que verifique qual a solução que melhor atenderá ao interesse coletivo envolvido, seja em se tratando de conflito coletivo (a tratar do meio ambiente, por exemplo), seja do conflito envolvendo determinado indivíduo (como o decorrente de contrato administrativo ou até mesmo o tributário). 
A mera existência de processo judicial posto à disposição dos jurisdicionados pode não mais satisfazer as garantias constitucionais nem tampouco o anseio social por adequados métodos de solução de controvérsias. Métodos alternativos ao judicial ganham, destarte, força e presença também nas relações estatais, sem perder de vista a necessária vinculação dos métodos aos princípios e valores constitucionais vigentes. No entanto, no Brasil não há regulamentação ampla e abrangente para soluções alternativas às controvérsias tributárias quer quando já há litígio instaurado (há previsão apenas de solução judicial ou processual administrativa), quer em caráter preventivo (ou seja, anteriormente à constituição de crédito tributário).

Na medida em que a controvérsia tributária, anterior e necessária à existência da lide, não surge em decorrência da vontade dos sujeitos envolvidos (mas lhes é imposta pelas normas que conferiram a determinado fato da vida real relevância para fins tributários) e, ainda, tendo em vista que a existência da lide não prescinde do processo judicial, entendemos viável tratar de meios de solução de controvérsias tributárias tanto preventivos quanto ulteriores à constituição do crédito tributário.

Para tanto, passo necessário foi a análise da natureza do crédito tributário vis a vis as exigências dos meios que se propôs estudar.

Em se tratando do objeto da relação jurídico tributária, a partir da análise dos artigos $3^{\circ}$ e 142 do Código Tributário Nacional concluiu-se que não há previsão de que se trataria o crédito tributário de bem jurídico indisponível. O que se percebeu, de fato, é que não deve ser conferida margem de discricionariedade ao administrador público que atua na cobrança e arrecadação de tributos no que tange à disposição de recursos, mormente os decorrentes de receita tributária. Sugere-se, assim, que a lei traga em detalhes quais os métodos a serem adotados, assim como a abrangência e margem da atuação dos agentes no momento da solução das controvérsias.

Nesse contexto, a arbitrabilidade do crédito tributário foi confirmada na medida em que, com vistas ao disposto no artigo $1^{\circ}$ da Lei da Arbitragem, o caráter patrimonial do crédito tributário é inequívoco e decorre da sua função precípua (qual seja, fonte de custeio para a atividade Estatal). Ademais, a indisponibilidade do crédito tributário, atendendo aos requisitos e premissas legais, estará sempre acompanhada de aspectos intrínsecos que lhe 
conferirão validade e efetividade. Destarte, na medida de expressa previsão legal permissiva, não há óbice para adoção da arbitragem tributária.

Ademais, que ao optar por solução arbitral para a controvérsia tributária o administrador público estará manifestando renúncia à jurisdição estatal e não ao crédito tributário na medida em que opta pelo julgamento da controvérsia por jurisdição outra que a Estatal, mas não trata de dispor do crédito tributário. Sem prejuízo, tal escolha deverá ocorrer sempre em atenção à estrita legalidade tributária, prescrita no artigo 150, I, da Constituição Federal.

Também com relação à manifestação de autonomia da vontade para fins de submeter o conflito à solução arbitral, encontrou-se perfeita harmonia com o artigo $2^{\circ}$ da Lei da Arbitragem. Não se afasta, no entanto, que em se tratando de direito tributário tal manifestação deverá encontrar limites e condições na lei, na medida em que não se pode afastar a legalidade nem tampouco a tipicidade tributárias. Outrossim, nem sempre a arbitragem poderá ser adotada como manifestação exclusiva da autonomia da vontade, o que se infere da própria necessidade de previsão legal para instauração da solução arbitral das controvérsias.

Materialmente, a arbitragem poderá sanar dúvidas quer em termos de interpretação e aplicação da legislação tributária, quer para solucionar questões fáticas, na medida em que haverá, efetivamente, incentivo ao diálogo entre fisco e contribuinte; ademais, a decisão imparcialmente tomada vinculará ambas as partes. Poderá, ainda, ser preventiva ou posterior à existência do crédito tributário.

A legalidade, a seu turno, permeará todo o procedimento arbitral, para o que se entende necessário firmar compromisso arbitral, com imprescindível fundamento legal, a tratar desde os aspectos relativos à competência das partes para submissão do conflito ao tribunal arbitral e também sobre a própria formação do ente julgador. Dentre os aspectos sobre os quais a lei deve expressamente dispor ressaltam-se o momento no qual a arbitragem poderia ser instaurada, a quantidade mínima de árbitros a compor o tribunal arbitral, a forma de se operar a eleição pela solução arbitral do conflito, a inviabilidade de instauração de arbitragem ad hoc e, finalmente, a impossibilidade de julgamento por equidade. 
Nem se vislumbre, ademais, desconsiderar o devido processo legal, o contraditório e a ampla defesa, a igualdade das partes, imparcialidade dos árbitros e seu livre convencimento (consoante previsão expressa do artigo 21, parágrafo $2^{\circ}$ da Lei da Arbitragem), sob pena de haver legitimidade para questionamento judicial do quanto venha a ser decidido na arbitragem.

Já no tocante à transigibilidade do crédito tributário, para transacionar o agente fiscal deverá ter poderes para renunciar à parcela do crédito tributário, de modo a conferir validade ao ato e também evitar seja desvirtuada a própria natureza da transação. A indisponibilidade do crédito tributário poderá ser mitigada na medida em que haja lei autorizando sua cessão, o que se conclui, sobretudo, diante da disposição expressa no sentido de que a lei poderá dispor sobre a transação tributária (artigos 156 e 171 do CTN). A transação já é realidade corrente no direito brasileiro, haja vista os programas para pagamento incentivado de tributos constantemente disponibilizados pelos fiscos federal, estaduais e municipais.

A possibilidade de fisco e contribuinte transigirem para fins de solução da controvérsia tributária não só estimula o diálogo entre os sujeitos envolvidos na relação jurídico-tributária, mas também permite que a tributação se dê de forma participativa, o que por certo conferirá segurança, confiabilidade e também reciprocidade nas relações tributárias, as quais, como amplamente exposto no decorrer do presente estudo, são complexas e nada cordiais sob a perspectiva do contribuinte. Tudo, sempre, em respeito à legalidade e tipicidade tributárias (artigo 150, I da Constituição Federal).

A lei, como em qualquer aspecto processual tributário, é premissa de validade da transação e deverá dispor sobre aspectos fundamentais, tais como a competência para transacionar, os critérios objetivos a capacitar o contribuinte elegível à transação com o fisco, assim como a matéria transacionável, para o que entendemos viável a transação anterior ou posterior à constituição do crédito tributário, a tratar de aspecto fático ou mesmo dúvidas de interpretação legal. 
A Lei de Responsabilidade Fiscal, por certo, deve ser observada e cumprida para fins de conferir fundamento de validade à transação tributária, mas não afasta sua viabilidade, sobretudo diante da preponderância de atendimento ao interesse público.

Quanto ao momento para se instaurar a transação, não se olvida de sua importância e viabilidade antes do curso de demanda judicial, mas entende-se também viável a solução transacional no curso do processo judicial ou arbitral, a ser levada a conhecimento do juízo competente para conhecimento e providências.

Importante destacar que, quer na arbitragem tributária, quer na transação, o Judiciário por vezes será acionado. Em caso de nulidades do procedimento ou mesmo para fins de imposição do quanto decidido, a jurisdição estatal poderá ser necessária eis que ponto comum a ambas as formas alternativas de solução de controvérsia aqui tratadas reside justamente na carência de força para impor sua decisão.

A proposta é, enfim, haja vista a constatação de que o atual cenário sugere sejam adotadas formas alternativas à judicial (estatal) para solução dos conflitos envolvendo físco e contribuinte, e diante da arbitrabilidade e transigibilidade das controvérsias tributárias, sejam adotadas pelos respectivos agentes competentes as providências legislativas indicadas neste estudo para que tais mecanismos sejam postos à disposição dos contribuintes e da fiscalização, em linha com a tendência mundial e com vistas a simplificar as relações e, sobretudo, incentivar o diálogo a proporcionar uma tributação mais participativa e responsiva. 


\section{BIBLIOGRAFIA}

ABRUCIO, Fernando Luiz. Trajetória recente da gestão pública brasileira: um balanço crítico e a renovação da agenda de reformas. Revista de Administração PúblicaRAP, RJ, FGV, Ed. Especial Comemorativa, 1967-2007, p. 67-86.

AMARAL, Paulo Osternack. Arbitragem e administração pública - aspectos processuais, medidas de urgência e instrumentos. Belo Horizonte: Fórum, 2012.

Vantagens, desvantagens e peculiaridades da arbitragem envolvendo o Poder Público. In: Arbitragem e Poder Público. PEREIRA, Cesar Augusto Guimarães; TALAMINI, Eduardo (coord). São Paulo: Saraiva, 2010.

ATALIBA, Geraldo. Hipótese de incidência tributária, $6^{\mathrm{a}}$ ed., $2^{\mathrm{a}}$ tiragem. São Paulo: Malheiros Editores, 2000.

Princípios constitucionais do processo e procedimento em matéria tributária, in Revista de Direito Tributário, São Paulo, n. 46, 1988.

Recurso em matéria tributária. Revista de informação legislativa, v. 25, n. $97, \quad$ p. 111-132, jan./mar. de 1988. Disponível em http://www2.senado.gov.br/bdsf/item/id/181823.

AVI-YONAH, Reuven S. International tax as international law: an analysis of the international tax regime. Cambridge taxlaw series. New York: 2007.

BALEEIRO, Aliomar. Direito tributário brasileiro. 10. ed. Rio de Janeiro: Forense, 1987. 
BANDEIRA DE MELLO, Celso Antonio. Curso de direito administrativo. $14^{\mathrm{a}}$ ed. São Paulo: Malheiros, 2001.

BATISTA JR., Onofre Alves. Transações Administrativas: um contributo ao estudo do contrato administrativo como mecanismo de prevenção e terminação de litígios e como alternativa à atuação administrativa autoritária, no contexto de uma administração pública mais democrática. São Paulo: Quartier Latin, 2007.

BINENBOJM, Gustavo. Temas de direito administrativo e constitucional. Rio de Janeiro: Renovar, 2008.

BLAKE, Susan; BROWNE, Julie; SIME, Stuart. A practical approach to Alternative Dispute Resolution. Oxford: University Press, 2011.

BRANCHER, Paulo. Soluções de Controvérsias e as Agências Reguladoras. Revista Brasileira de Arbitragem, n. 1. São Paulo: 2004.

BRESSER-PEREIRA, Luiz Carlos. O modelo estrutural de governança pública, RERE 10.

CAIS, Cleide Previtalli. O Processo tributário, $4^{\text {a }}$ ed. São Paulo: RT, 2004.

CAMPOS, Diogo Leite de. “A arbitragem em direito tributário português e o estado-doscidadãos”, Revista de Arbitragem e Mediação, São Paulo: Revista dos Tribunais, v. 4, No. 12, 2007, p. 149-458.

CANOTILHO, José Joaquim Gomes. Brancosos e Interconstitucionalidade: itinerários dos discursos sobre historicidade constitucional. Coimbra: Almedina, 2006.

CAPPELLETTI, Mauro; GARTH, Bryan. Access to Justice, vol.I, Book I, Milano, Giuffrè, 1978.

CARMONA, Carlos Alberto de. A crise do processo e os meios alternativos para a solução de controvérsias, Revista de Processo, v. 56, p. 91-99. 
. Arbitragem e jurisdição. Revista de Processo, São Paulo, v. 58, p. 3340, 1990.

. Arbitragem e processo: um comentário à Lei $n^{\circ}$ 9.307/96. 2. ed. São Paulo: Atlas, 2006.

Flexibilização do processo arbitral. Revista Brasileira de Arbitragem, São Paulo, v. 24, p. 7-21, 2010. . O processo arbitral. Revista de Arbitragem e Mediação, São Paulo, v. 1, p. 21-31, 2004.

CARVALHO, Fabio Junqueira de; MURGEL, Maria Inês. Órgão julgador administrativo necessidade de o mesmo ser paritário. In Processo administrativo fiscal, $4^{\circ}$ volume. Coordenador Valdir de Oliveira Rocha. São Paulo: Dialética, 1999, p. 2744.

CARVAlHO, Paulo de Barros. Direito tributário, linguagem e método. São Paulo: Noeses, 2008.

CASTELLS, Manuel. A sociedade em rede. São Paulo: Paz e Terra, 1999.

CHAYES, Abram. The role of the judge in public law litigation. Harvard Law Review, vol. 89 (maio/1976).

CHITI, Mario. Le forme di risoluzione delle controversie com la pubblica amministrazione alternative alla giurisdizione. Rivista Italiana di diritto pubblico comunitário, Milano, a. 10, n. 1, p. 1-23, 2000.

CINTRA, Antonio Carlos de Araújo; GRINOVER, Ada Pellegrini; DINAMARCO, Cândido Rangel. Teoria Geral do Processo. $18^{\mathrm{a}}$ edição. São Paulo: Malheiros, 2002. 
COSTA, Marcos Gomes da. Tutela de urgência e processo arbitral, dissertação de mestrado defendida em 10 de junho de 2013 na Faculdade de Direito da Universidade de São Paulo.

COSTA, Regina Helena. Código Tributário Nacional comentado: doutrina e jurisprudência, artigo por artigo. FREITAS, Vladimir Passos de (coord). $2^{\mathrm{a}}$ ed. São Paulo: Editora Revista dos Tribunais, 2004.

CRUZ, Paulo Ricardo de Souza, A Transação no Direito Tributário, Dissertação de Mestrado, Belo Horizonte, UFMG, 2004.

DACOMO, Natalia de Nardi. Direito Tributário Participativo. Transação e arbitragem administrativas da obrigação tributária. São Paulo: Quartier Latin, 2009.

DALLARI, Adilson de Abreu. Arbitragem na concessão de serviço público. Revista de Informação Legislativa, n. 128 (out./dez.1995).

DE LUCA, Gianni, Compendio di Diritto Tributario. XX Ed. Edizioni Giuridiche Simone, 2012.

DINAMARCO, Cândido. Instituições de direito processual civil. Volume I. São Paulo: Malheiros, 2001.

. Instituições de direito processual civil. Volume II. São Paulo: Malheiros, 2005.

DI PIETRO, Maria Sylvia Zanella. Direito Administrativo. 26a ed. São Paulo: Ed. Atlas, 2013.

Discricionariedade administrativa e controle judicial da administração, in Processo Civil e interesse público. O processo como instrumento de defesa social. SALLES, Carlos Alberto de (org.). São Paulo: Editora Revista dos Tribunais, 2003. 
O princípio da supremacia do interesse público: sobrevivência diante dos ideais do neoliberalismo. In: DI PIETRO, Maria Sylvia Zanella et al. (Coords.). Supremacia do interesse público e outros temas relevantes do direito administrativo. São Paulo: Atlas, 2010.

ESCOLA, Héctor Jorge. El interés público: como fundamento del derecho administrativo. Buenos Aires: Depalma, 1989.

ESQUÍVEL, José Luís. Os contratos administrativos e a arbitragem. Coimbra: Almedina, 2004.

Estudo sobre o Custo Unitário do Processo de Execução Fiscal na Justiça Federal. Relatório publicado pelo IPEA e CNJ em Brasília, 2011.

Estudo sobre Execuções Fiscais no Brasil, promovido pela Secretaria de Reforma do Judiciário do Ministério da Justiça, com apoio do Centro Brasileiro de Estudos e Pesquisas Judiciária (CEBEPEJ), São Paulo, 2007.

FALSITTA, Gaspare. Manuale di Diritto Tributario - parte generale. $8^{\mathrm{a}}$ ed. Revisada.Casa Editrice Dott. Antonio Milani. Padova: Cedam, 2012.

FARIA, José Eduardo de. O Estado e o direito depois da crise. No prelo.

FAZZALARI, Elio. Instituzioni di diritto processuale. VIII Edizione. Padiva: CEDAM, 1996.

FERRARA, Frabco Batistoni e BELLÈ, Brunella, Diritto tributatio processuale. $4^{\mathrm{a}}$ ed. Casa Editrice Dott. Antonio Milani: Cedam, 2011.

FISS, Owen. Um novo processo civil: estudos norte-americanos sobre jurisdição, constituição e sociedade. São Paulo: RT, 2004. 
GABBAY, Daniela Monteiro et al. Segunda fase do projeto de pesquisa "arbitragem e Poder Judiciário" - Parceria institucional acadêmico-científica da Escola de Direito de São Paulo da Fundação Getúlio Vargas (Direito GV) e do Comitê Brasileiro de Arbitragem (CBAr). Relatório do Tema: Validade, Eficácia e Existência da Convenção Arbitral. p. 1/29 e 38/41. Disponível em <http://www.cbar.org.br/PDF/Validade_Eficacia_e_Existenciada_Convencao_Ar bitral.pdf>. Acesso em 19/10/2010.

GALANTER, Marc. Introdução comparado a quê? Avaliando a qualidade dos mecanismos de solução de disputas, Denver University Law Review, n. 66, v. 3. Trad. Marcos Paulo Veríssimo.

GAROT, Marie Jose. De La administracion electronica a uma democracia digital. Revista Direito GV, v. 2, n. 1, jan/jun 2006, p. 89-110.

GIUSTI, Gilberto. O árbitro e o juiz: da função jurisdicional do árbitro e do juiz. Revista Brasileira de Arbitragem, n. 5, jan/mar 2005, p. 7-14.

GODOI, Marciano Seabra de. Sobre a possibilidade de a Fazenda Pública reverter, em juízo, decisões definitivas dos Conselhos de Contribuintes. In Grandes questões atuais do direito tributário, $9^{\circ}$ volume, ROCHA, Valdir de Oliveria (coord). São Paulo: Dialética, 2005, p. 396-410.

GODOY, Arnaldo Sampaio de Moraes. Transação tributária: introdução à Justiça Fiscal Consensual. Belo Horizonte: Ed. Forum, 2010.

. Transação tributária: paradoxos e possibilidades. Tributação em Revista, v. 16, p. 23-32, 2010.

GOLDSCHMIDT, Fabio Brun. Arbitragem e Transação Tributária-Verificação de Compatibilidade. Revista Dialética de Direito Tributário. São Paulo. n.48. Setembro de 1999. p.47/64. 
GONÇALVES, Pedro. Entidades privadas com poderes públicos. Coimbra: Almedina, 2005.

GRAU, Eros Roberto. Arbitragem e contrato administrativo, Revista trimestral de direito público, v. 32, p. 14-20.

GRILLO, Fabio Artigas. Transação e justiça tributária. Tese de doutorado apresentada ao Programa de Pós-Graduação em Direito, Faculdade de Direito da Universidade Federal do Paraná. Curitiba: 2012.

GRINOVER, Ada Pellegrini. Arbitragem e prestação de serviços públicos, in RDCPC, N. 26, Nov. / dez. 2003, p. 65.

A crise do poder judiciário. O processo em evolução. Rio de Janeiro: Forense Universitária, 1996.

- Os fundamentos da Justiça conciliativa, Revista de Arbitragem e Mediação, ano 4, n. 14, jul-set. 2007.

GRINOVER, Ada Pellegrini e WATANABE, Kazuo, Política Pública do Poder Judiciário Nacional para tratamento adequado dos conflitos de interesses. Disponível em <http://www.tjsp.jus.br/Download/Conciliacao/Nucleo/ParecerDesKazuoWatanab e.pdf>, acesso em 21.06.2012.

GUERRERO, Luis Fernando. Convenção de arbitragem e processo arbitral. São Paulo: Atlas, 2009.

HEIDELBERG, Christoph Mollers. Transnational governance without a public law? Transnational governance and Constitucionalism. Edited by JOERGES, Christian; SAND, Inger-Johanne e TEUBNER, Gunther. Hart Publishing, 2004.

HORVATH, Estevão. Lançamento Tributário e “Autolançamento”. $2^{\circ}$ ed. São Paulo: Quartier Latin, 2010. 
HOSSNE, Beatriz de Araujo Leite Nacif, Da execução por quantia certa contra a Fazenda Pública: aspectos polêmicos. Revista de Processo, São Paulo, v. 38, n. 216, p. 109-125, fev. 2013.

ICC International Court of Arbitration Bulletin, vol. 21/1, 2010.

JESSOP, Bob. Narrating the future of national economy and national State? Remarks on remaping regulation and the reinventing governance. Lancaster, Department of Sociology, Lancaster University, LA 14YN.

JOBIM, Eduardo; MACHADO, Rafael Bicca (coord.). Arbitragem no Brasil: aspectos jurídicos relevantes. São Paulo: Quartier Latin, 2008.

KOMESAR, Neil K. Law's limits: the rule of law and the supply and demand of rights. Cambridge University, 2001.

KUNTZ, Rolf. O poder como direito e outros estudos de filosofia politica, trabalho de livre-docência apresentado à FLCH da USP, São Paulo, 2009.

LEMES, Selma Maria Ferreira. Convenção de arbitragem e termo de arbitragem: características, efeitos e funções. Disponível em: <http://www.selmalemes.com.br/artigos/artigo_juri07.pdf>. Acesso em: 13 fev. 2012.

LEMES, Selma Maria Ferreira. Arbitragem na Administração Pública. Fundamentos Jurídicos e Eficiência Econômica. São Paulo: Quartier Latin. 2007.

. Convenção de arbitragem e termo de arbitragem: características, efeitos funções. <http://www.selmalemes.com.br/artigos/artigo_juri07.pdf>. Acesso em: 13 fev. 2012.

Princípios e origens da lei de arbitragem, Revista do advogado, Associação dos Advogados de São Paulo, - ASSP, São Paulo, n 51, p. 32-35. 
- Princípios informativos do contencioso administrativo tributário federal, Revista de Informação Legislativa, Brasília, a. 15, n. 58, abr/jun 1978.

LORENCINI, Marco Antonio Garcia Lopes. A contribuição dos meios alternativos para a solução de controvérsias, in SALLES, Carlos Alberto de (org.). As grandes transformações do Processo Civil Brasileiro: homenagem ao Professor Kazuo Watanabe. São Paulo: Quartier Latin, 2009, p. 599-626.

LUCHIARI, Valeria Ferioli Lagrasta. Gerenciamento do Processo e meios alternativos de solução de conflitos. In SALLES, Carlos Alberto de (org.). As grandes transformações do Processo Civil Brasileiro: homenagem ao Professor Kazuo Watanabe. São Paulo: Quartier Latin, 2009.

MACHADO, Hugo de Brito. Transação e arbitragem no âmbito tributário. In SARAIVA FILHO, Oswaldo Othon de; GUIMARÃES, Vasco Branco. (org.) Transação e arbitragem no âmbito tributário. Homenagem ao jurista Carlos Mario da Silva Velloso. São Paulo: São Paulo: Ed. Fórum, 2008.

A transação no Direito Tributário. Revista Dialética de Direito Tributário, n. 75. São Paulo, 2001, p. 60-70.

MACHETE, Pedro. Estado de direito democrático e administração paritária. Coimbra: Almedina, 2007.

MAINWARING, Scott. Introduction: democratic accountability in Latin America. In MAINWARING, Scott. E WELNA, Christopher. Democratic accountability in Latin America. Oxford/New York: Oxford University, 2003.

MAJONE, Giandomenico. Do estado positivo ao estado regulador: causas e consequências da mudança no modo de governança. In: MATTOS, Paulo Todescan L. [et all.]. Regulação econômica e democracia: o debate europeu. São Paulo: Singular, 2006. 
MANCUSO, Rodolfo de Camargo, A resolução dos conflitos e a função judicial no contemporâneo Estado de Direito. São Paulo: Revista dos Tribunais, 2009.

O plano piloto de conciliação em segundo grau de jurisdição, do Egrégio Tribunal de Justiça de São Paulo, e sua possível aplicação aos feitos de interesse da Fazenda Pública. In MARINONI, Luiz Guilherme (Coord). Estudos de Direito Processual Civil - homenagem ao Professor Egas Dirceu Moniz de Aragão. São Paulo: Editora Revista dos Tribunais, 2005.

MARINS, James. Defesa e vulnerabilidade do contribuinte. São Paulo: Dialética, 2009.

Direito processual tributário brasileiro - administrativo e judicial. São Paulo: Dialética, 2003.

MARQUES, Floriano Azevedo. Discricionariedade administrativa e controle judicial da administração. Processo Civil e interesse público. O processo como instrumento de defesa social. SALLES, Carlos Alberto de (org.). São Paulo: Editora Revista dos Tribunais, 2003.

MARTINS FILHO, Luiz Dias; ADAMS, Luís Inácio Lucena. A transação no Código Tributário Nacional (CTN) e as novas propostas normativas de lei autorizadora. Transação e Arbitragem no âmbito tributário - homenagem ao jurista Carlos Mário da Silva Velloso, Saraiva Filho, Oswaldo Othon de Pontes e Guimarães, Vasco Branco (org.). São Paulo: Ed. Fórum, 2008, PP. 15-42.

MARTINS, Pedro A. Batista. O Poder Judiciário e a arbitragem: quatro anos da Lei $\mathrm{n}^{\circ}$ 9.307/96. $3^{\text {a }}$ parte. Revista Forense. v. 98, n. 359, Rio de Janeiro: 2002.

MEDAUAR, Odete. A Processualidade do Direito Administrativo, São Paulo, Ed. RT, 1993. 
MENDONÇA, Priscila Faricelli de, Coisa Julgada Tributária, Revista Tributária e de Finanças Públicas, RTRIB, ano 19, v. 98, maio-jun. 2011.

A transação na solução de controvérsias tributárias: uma análise das hipóteses legais. No prelo.

Notas sobre o princípio da publicidade processual na atualidade: processo eletrônico e mídia. Revista Dialética de Direito Processual. V. 101. Agosto-2011.

MONTEIRO, Alexandre Luiz Moraes do Rêgo; MORAES E CASTRO, Leonardo Freitas de. Direito Tributário e arbitragem: uma análise da possibilidade e dos óbices ao juízo arbitral em matéria tributária no Brasil. Revista Tributária e de finanças públicas. Ano 17, n. 88, 2009, p. 18-47.

MORAIS, Caio Yuri Araújo. Transação e arbitragem em matéria tributária: a experiência estrangeira e sua aplicabilidade ao direito brasileiro, In: SARAIVA FILHO, Oswaldo Othon de pontes; GUIMARÃES, Vasco Branco (org.). Transação $e$ arbitragem no âmbito tributário: homenagem ao jurista Carlos Mário da Silva Velloso. Belo Horizonte: Fórum, 2008, p. 483-503.

NABAIS, José Casalta, Reflexão sobre a introdução da arbitragem tributária, Revista da Procuradoria Geral da Fazenda Nacional, ano I, No. 1, p. 19-43.

NEDER, Marcos Vinícius; LOPES, Maria Teresa Martinez. Processo administrativo fiscal federal comentado. 3 ed. São Paulo: Dialética, 2010.

NOVOA, César García. Mecanismos alternativos para la resolución de controversias tributarias. Su introducion em el derecho español. In JOBIM, Eduardo; MACHADO, Rafael Bicca (coord.). Arbitragem no Brasil: aspectos jurídicos relevantes. São Paulo: Quartier Latin, 2008. 
NUNES, Thiago Marinho, A prática das 'anti-suit injunctions' no procedimento arbitral e seu recente desenvolvimento no direito brasileiro, Revista Brasileira de Arbitragem, n. 5, jan/mar/2005, PP. 15-51.

OLIVEIRA, Gustavo Justino de. A arbitragem e as parcerias público-privadas. In SUNDFELD, Carlos Ari (org.). Parcerias Público-privadas. São Paulo: Malheiros, 2007, p. 567/602.

. Direito administrativo democrático. Belo Horizonte: Fórum, 2010.

. Governança pública. Gazeta do Povo. 15.jun.2008, p. 2.

OWENS, Jeffrey. OECD Proposal to improve the resolution of tax treaty disputes. EuropeanTaxation. June 2007.

PISCITELLI, Tathiane dos Santos. Argumentando pelas consequências no direito tributário. São Paulo: Noeses, 2011.

REALE, Miguel. Crise da Justiça e Arbitragem, in Revista de Arbitragem e Mediação, v. 36 , p. 319 , jan/2013.

Relatório IJC Brasil relativo ao $1^{\circ}$ Trimestre de 2012.

RIBAS, Antonio Souza e RIBAS, Lídia Maria Lopes Rodrigues. Arbitragem como meio alternativo na solução de controvérsias tributárias. Revista Tributária e de Finanças Públicas, n. 60, São Paulo: 2005, p. 223-247.

RISKIN, Leonard L e WESTBROOK, James E. Dispute resolution and lawyers. Abridgededition. West PublishingCO: St. Paul, Minesotta, 1987.

ROMERO, Eduardo Silva. International arbitration involving state parties. Observations on the applicable Law in state contract arbitration. Revista de Arbitragem e Mediação No. 6. 
RODRIGUES, Walter Piva. Coisa julgada tributária. São Paulo: Quartier Latin, 2008.

SALLES, Carlos Alberto de. A arbitragem na solução de controvérsias contratuais da administração pública. Rio de Janeiro: Forense; São Paulo: Método, 2011.

Políticas públicas e legitimidade para defesa de interesses difusos e coletivos. Revista de Processo, v. 121, p. 38-50, 2005.

Processo Civil e Interesse Público: o processo como instrumento de defesa social. São Paulo: Revista dos Tribunais, 2003.

SANTAMARIA, Baldassarre, Diritto Tributario, parte generale. Sexta Edizione. Milano, Giuffrè Editore: 2008.

SANTI, Eurico Marcos Diniz de. Transação e arbitragem no direito tributário: paranoia ou mistificação? In: SARAIVA FILHO, Oswaldo Othon de pontes; GUIMARÃES, Vasco Branco (org.). Transação e arbitragem no âmbito tributário: homenagem ao jurista Carlos Mário da Silva Velloso. Belo Horizonte: Fórum, 2008, p. 167190.

Processo judicial. Mesa de debates "d". Publicada em Revista de Direito Tributário, v. 101, p. 93-131.

SARAIVA FILHO, Oswaldo Othon de; GUIMARÃES, Vasco Branco. (org.) Transação e arbitragem no âmbito tributário. Homenagem ao jurista Carlos Mario da Silva Velloso. São Paulo: Ed. Fórum, 2008.

SARAIVA FILHO, Oswaldo Othon de. Visão da sociedade sobre transações tributárias. Revista Fórum de Direito Tributário - RFDT, Belo Horizonte, ano 7, n. 40, p. 5359. 
A transação e a arbitragem no direito constitucional-tributário brasileiro. In SARAIVA FILHO, Oswaldo Othon de; GUIMARÃES, Vasco Branco. (org.) Transação e arbitragem no âmbito tributário. Homenagem ao jurista Carlos Mario da Silva Velloso. São Paulo: Ed. Fórum, 2008.

SEIDMAN, Harold; GILMOUR, Robert. Politics, position and Power. Fourth Ed. New York: Oxford University Press, 1986.

SEIXAS FILHO, Aurélio Pitanga. A solução de controvérsias fiscais por meio de arbitragem. Revista de Arbitragem e mediação. Vol. 22. Jul.2009.

SHAPIRO, Martin. Who guards the guardians? Judicial control of administration. The Richard B. Russel Lectures. Athens and London: the University f Georgia Press.

SILVA, Eduardo da e DALMAS, Samis Bahlis, Câmara de Arbitragem da AGU e modelo arbitral brasileiro: aproximações e distinções, in Revista de Processo, v. 217, p. 341.

SOUZA JR., Lauro da Gama. Sinal verde para a arbitragem em parcerias público-privadas (a construção de um novo paradigma para os contratos entre o Estado e o investidor privado). Revista Brasileira de Arbitragem, n. 8, out-dez/2005, p. 7-40.

SZKLAROWSKY, Leon Fredja, A arbitragem - uma visão crítica, Revista de Processo, vol. 212, set. 2012, p. 203.

TÁCITO, Caio. Arbitragem nos litígios administrativos, in Revista de Direito Administrativo, v. 242, Out./Dez. 2005, p. 139-143.

TALAMINI, Eduardo. “A (in)disponibilidade do interesse público: consequências processuais - composição em juízo, prerrogativas processuais, arbitragem e ação monitória". Revista de Processo n. 128. p. 59-77.

THEODORO JUNIOR, Humberto. Arbitragem e terceiros. Litisconsórcio fora do pacto arbitral. Outras intervenções de terceiros. Revista Forense, vol. 362, p. 41-61. 
.. Celeridade e efetividade da prestação jurisdicional. Insuficiência da reforma das leis processuais. Revista de Processo, vol. 112, p. 61-78.

TORRES, Heleno Taveira. Princípios de segurança jurídica e transação em matéria tributária. Os limites da revisão administrativa dos acordos tributários. In SARAIVA FILHO, Oswaldo Othon de; GUIMARÃES, Vasco Branco. (org.) Transação e arbitragem no âmbito tributário. Homenagem ao jurista Carlos Mario da Silva Velloso. São Paulo: São Paulo: Ed. Fórum, 2008, p. 299-330.

Arbitragem e transação em matéria tributária. In JOBIM, Eduardo; MACHADO, Rafael Bicca (coord.). Arbitragem no Brasil: aspectos jurídicos relevantes. São Paulo: Quartier Latin, 2008.

. Transação, arbitragem e conciliação judicial como medidas alternativas para resolução de conflitos entre administração e contribuintes - simplificação e eficiência administrativa. Revista Dialética de Direito Tributário. São Paulo: Malheiros, No. 86, 2002, p. 40-64.

TORRES, Ricardo Lobo. Transação, conciliação e processo tributário administrativo equitativo. SARAIVA FILHO, Oswaldo Othon de; GUIMARÃES, Vasco Branco. (org.) Transação e arbitragem no âmbito tributário. Homenagem ao jurista Carlos Mario da Silva Velloso. São Paulo: São Paulo: Ed. Fórum, 2008.

VERDE, Giovanni. L' arbitrato e la giurisdizione ordinaria. In: VERDI, Giovanni (a cura dio). Diritto dell'arbitrato. 3. ed. Torino: G. Giappichelli Ed., 2005.

WALD FILHO, Arnold. Novos rumos para a arbitragem. In Revista de arbitragem e mediação. São Paulo: Revista dos Tribunais, ano 5,vol. 16, 2008, p. 49-53.

WATANABE, Kazuo. Cultura da sentença e cultura da pacificação. In: YARSHELL, Flávio Luiz e MORAES, Maurício Zanoide de (coord.) Estudos em homenagem à professora Ada Pellegrini Grinover. São Paulo: DPJ, 2005. 
XAVIER, Alberto. Do lançamento - teoria geral do ato do procedimento e do processo tributário. Rio de Janeiro: Forense, 1998.

YARSHELL, Flávio. A execução e a efetividade do processo em relação à fazenda. In SUNDFELD, Carlos Ari; BUENO, Cassio Scarpinella (coords.) Direito Processual Público. A Fazenda Pública em Juízo. Sociedade Brasileira de Direito Público. São Paulo: Malheiros, 2000.

- Caráter Subsidiário da ação anulatória de sentença arbitral, Revista de Processo, v. 207, maio/2012, p. 13. 


\section{SITES CONSULTADOS}

www.agenziaentrate.gov.it

www.cnj.jus.br

Www.irs.gov

WwW.oecd.org

www.pgfn.fazenda.gov.br

www.receita.fazenda.gov.br

www.stf.jus.br

www.stj.jus.br

www.trf1.jus.br

www.trf3.jus.br

www.trf4.jus.br 


\section{RESUMO}

O objetivo da presente dissertação de mestrado foi o de, a partir de uma análise fática das discussões judiciais travadas entre fisco e contribuinte para solução de controvérsias tributárias, constatar a ineficiência do sistema atualmente posto à disposição dos sujeitos envolvidos em tais relações e buscar soluções processualmente viáveis, com foco em mecanismos consensuais (transação) ou adjudicatórios de base consensual (arbitragem).

Para tanto, partiu-se de uma análise do atual cenário dos litígios judiciais envolvendo fiscos e contribuintes, concluindo-se pela incapacidade do sistema a proporcionar soluções satisfatórias e tratamento adequado ao conflito (Parte I, Capítulo 1). Diante da realidade fática enfrentada, o problema é proposto para soluções de controvérsias tributárias, frente ao regime de indisponibilidade do crédito tributário.

Na nova moldura das relações que envolvem o Estado, tendo em vista que não se afasta disponibilidade do crédito tributário desde que se dê nos termos da lei (Parte I, Capítulo 2), passou-se a uma análise dos meios atualmente postos à disposição dos físcos e contribuintes para solução das controvérsias tributárias, vislumbrando-se, ao final, pela viabilidade de adoção de meios alternativos para solução de tais controvérsias (Parte I, Capítulo 3).

A segunda parte do estudo é voltada à análise da arbitragem tributária, partindo da arbitrabilidade do crédito tributário (Parte II, Capítulo 1) até os requisitos formais e processuais para adoção de tal método privado e de base consensual para solução de conflitos tributários. Feitas as premissas necessárias, tratou-se dos aspectos processuais da arbitragem tributária, sempre os vinculando à estrita legalidade que permeia tais relações e será premissa de validade do procedimento que se cogita (Parte II, Capítulo 2). 
Finalmente, na terceira parte é feita a avaliação acerca da transigibilidade das controvérsias tributárias (Parte III, Capítulo 1) para, após, verificar os aspectos processuais da transação tributária, sempre com vistas à legalidade, tipicidade cerrada e limites impostos pela Lei de Responsabilidade Fiscal.

Palavras-chave: Meios alternativos de solução de controvérsias - Direito tributário - Arbitragem - Transação. 


\begin{abstract}
This dissertation aims at looking for feasible solutions from a procedural standpoint, based on a factual analysis of tax judicial lawsuits between the taxpayers and the Government that verified the inefficiency of the system currently made available to the parties involved in the said disputes, focused on the possibility of adopting the arbitration and transaction.
\end{abstract}

Initially, it is discussed the current scenario of the judicial tax litigation, which resulted in the conclusion of the inability of the system to provide satisfactory solutions and appropriate treatment to the relevant conflicts (Part I, Chapter 1). Given such scenario, the proposed problem is how to use consensual mechanisms (transaction) or adjudicatorybased consensus procedures (arbitration) to resolve tax controversies, vis a vis the regime of unavailability of the tax credit.

In the new framework of relations involving the States, which allows the availability of the tax credit strictly under the law (Part I, Chapter 2), it is analyzed the ways currently available to the tax authorities and taxpayers for the resolution of tax controversies and it is concluded for the feasibility of adopting alternative dispute resolution (ADR) methods (Part I, Chapter 3), in addition to the adjudicative resolution of the conflicts.

Then, the second part of the study is focused on the analysis of tax arbitration, moving from the arbitrability of the tax credit (Part II, Chapter 1) to the substantive and procedural requirements for adopting such a method private and consensual-based for resolving tax disputes. As the necessary premises were confirmed, it is analyzed the procedural aspects of tax arbitration, always linking them to the strict legality that permeates tax matters and will utmost validate the arbitration for tax matters (Part II, Chapter 2). 
Finally, the third part is an evaluation about the possibility of tax transaction (Part III, Chapter 1); after that, it is analyzed the procedural aspects of the transaction for tax purposes, always under the strict legality and the limits imposed by the Fiscal Responsibility Law (Part III, Chapter 2).

Key words: Alternative Dispute Resolution (ADR) - Tax Law - Arbitration Transaction. 